Facultad de Humanidades y Ciencias de la Educación

Universidad Nacional de La Plata

\title{
LA NOVELA HISTÓRICA DE LA POSDICTADURA EN URUGUAY
}

(1985-1995)

Teresa Basile

Directora: Susana Zanetti

2002 


\section{LA NOVELA HISTÓRICA EN LA POSDICTADURA URUGUAYA}

Facultad de Humanidades y Ciencias de la Educación............... 1

Universidad Nacional de La Plata............................................. 1

LA NOVELA HISTÓRICA DE LA POSDICTADURA EN

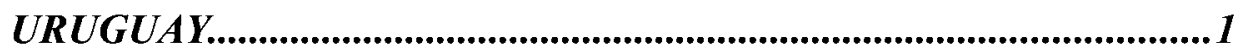

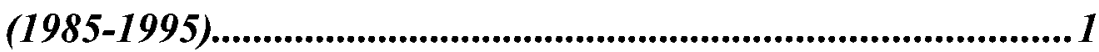

INTRODUCCIÓN___ 5

I. CRISIS Y REVISIÓN DE LA IDENTIDAD URUGUAYA_ 11

1-La posdictadura como un nuevo lugar de enunciación_____ 11

2. Fracturas y revisiones del discurso de identidad 24

2.1. A la deriva...__ 24

2.2. El origen como contrautopia _ـ 27

2.3. Los desvelos del Mercosur 29

2.4. La "débil heterogeneidad"___ 31

2.5. El "diálogo controversial"___ 32

II LA ÉPICA DE LOS ORÍGENES. EL CICLO DE NOVELAS HISTÓRICAS DE EDUARDO ACEVEDO DÍAZ 36

1 La Novela histórica__ 36

1.1 La epopeya científica _ـ_____ 36

1.2 Espiritualismo y positivismo___ 41

2 Un proyecto nacional ___ 44

La narración de la nación y sus emblemas $\quad 49$

$2.1 \mathrm{La}$ tesis de la independencia clásica _ $\quad 50$

Presente/ Pasado: la historia como tradición revolucionaria $\quad 60$

Revolución: principismo y romanticismo_________ 63

2.2 El proyecto civilista___ 64

Las edades de la historia y las fuerzas de avance y retroceso__ 65

2.3 El discurso de la abundancia $\quad 75$ 
Muralla y Enciclopedia $\quad 80$

Del "pago" a la "patria": la figura del forastero____ 82

Romanticismo y realismo-naturalismo___ 84

Las escenas amorosas $\quad 85$

La naturaleza______ 87

III ¡BERNABÉ, BERNABÉ! DE TOMÁS DE MATTOS O LAS NUEVAS CARTOGRAFÍAS DE LA HISTORIA

3.1 La trama temporal. Los recuerdos del porvenir. Hacia un mapa de las dictaduras 90

3.2 La identidad en crisis. Del espejo narcisista al charco ___ 96

3.3 La ética militar _ 101

3.4 La obediencia debida___ 103

3.5 Las diversas historias. El Archivo Narbondo y el relato de los charrúas

3.6 Las femeniles disquisiciones. A modo de reflexión final_116

3.7 Apéndice 118

IV LAS IDENTIDADES OLVIDADAS. LA FRAGATA DE LAS MÁSCARAS DE TOMÁS DE MATTOS 120

1 Las miradas y las voces $\quad 121$

2 Ecce niger 136

3 Los temas 144

3.1 La opresión__ 144

3.2 El motín o la revolución___ 150

3.3 El juicio__ 152

$3.4 \mathrm{El}$ guano y la tina __ 156

4 La utopía___ 157

5 La posdictadura desde la herencia cristiana _________ 159

V VARIACIONES SOBRE LA MEMORIA. EL PRÍNCIPE DE LA MUERTE DE FERNANDO BUTAZZONI___ 167

1 Las memorias olvidadas ___ 173

2 Los usos de la memoria___ 185

3 El príncipe de la muerte de Fernando Butazzoni_______ 189

VI LOS ARCHIVOS DE LA VIDA PRIVADA

$1 \mathrm{El}$ archivo de Soto de Mercedes Rein 
Los entresijos de la historia 202

2 Una cinta ancha de bayeta colorada. Desandanzas del Goyo Jeta de Hugo Berbejillo 206

3 El Archivo 213

4 Los íconos de la nacionalidad 220

5 El imaginario de la(s) dictadura(s) 224

VII EL ARTE DE BORRAR EN ARTIGAS BLUES BAND DE AMIR HAMED 232

1 Escritura/ retroescritura 232

2 Artigas Blues Band de Amir Hamed 244 VIII HISTORIA Y FICCIÓN 266

BIBLIOGRAFIA 276

1 Corpus Textual 276

a) Corpus textual de E. Acevedo Díaz 276

b) Novelas Históricas de la posdictadura 276

2 Cuestiones teoricas sobre ficción, historia, temporalidad 276

3 Novela histórica/ perspectivas teóricas 277

a) Perspectivas teóricas sobre novela histórica 277

b) Perspectivas teóricas generales 278

c) Crítica sobre la obra de Acevedo Díaz 279

4 Historia y cultura uruguaya 279

5 Dictadura. historia y critica literaria 280

6 Debates de fin e siglo 281

7 Artículos, entrevistas, polémicas aparecidas en semanarios, suplementos culturales y revistas de uruguay 282 


\title{
LA NOVELA HISTÓRICA EN LA POSDICTADURA URUGUAYA
}

\author{
¿Qué hace una puerta cuando, al abrirse, da a otra puerta? \\ ¿Y, sobre todo, cuando da a una puerta que ya se ha pasado, \\ al paso (de lo) que viene?
}

Derrida

\section{INTRODUCCIÓN}

La posdictadura en el Cono Sur emerge como un nuevo espacio de enunciación a partir del inicio de los procesos democráticos y dispone una renovada agenda de problemas centrados tanto en las herencias de las dictaduras como en la necesidad de organizar las recientes democracias. Es, ante todo, una perspectiva crítica focalizada en la "dictadura" como sistema de dominio, aunque no se agota en ella. Varios son los trabajos de los últimos años dedicados a indagar los efectos de los procesos dictatoriales en las sociedades de la región. Problemas como la memoria, la justicia, los derechos humanos, las identidades, "los desaparecidos", el surgimiento de nuevos sectores y movimientos de protesta o las transformaciones del rol del intelectual y las reconfiguraciones de los géneros literarios son abordados desde diversas disciplinas.

En este marco mi interés se concentra en los aportes de la novela histórica uruguaya a los debates abiertos en la posdictadura y en las peculiaridades que este subgénero imprime a sus propuestas, el ángulo nuevo que ofrece. 
En primer lugar quiero destacar el reclamo -que la novela histórica hace visible- de una relectura y reescritura global de la historia uruguaya desde su "origen" en las guerras de Independencia. Este gesto señala un profundo quiebre en los ideales e imaginarios con los cuales los uruguayos se identificaban y pone en evidencia una aguda desconfianza en las narraciones heredadas sobre la nación. En este sentido la experiencia de la dictadura constituyó una fractura que impulsó el cuestionamiento de sus relatos consolidados y su necesaria reescritura bajo diferentes presupuestos. En el prefijo "post" de posdictadura es posible advertir no sólo una dimensión temporal sino un giro epistémico que reorganiza los dispositivos identitarios, los imaginarios comunitarios y los relatos nacionales desde otro locus de enunciación. Este cambio de paradigma lo expone de un modo notable la novela histórica en tanto cuestiona el "origen" de la nación y con ello los andamios que sostenían el entero edificio.

En segundo lugar, el conjunto de novelas históricas de estos años lee el pasado desde la nueva agenda del presente. Cuestiones como la memoria, la justicia, la tolerancia, las identidades excluidas, los autoritarismos se discuten desde la peculiar perspectiva de la novela histórica que los desplaza hacia el pasado.

La reescritura del pasado, como sabemos, se constituye $-\mathrm{y}$ ahora de un modo notable- desde las preocupaciones del presente.' Éste se convierte en un foco que ilumina zonas en penumbras del pasado, desentierra historias semiolvidadas, escarba en archivos particulares y oficiales, pone en escena problemáticas ausentes. Desde la lente de la

1 Si la imposibilidad de describir desde el presente "lo que realmente sucedió" ha llevado buena dosis de escepticismo y cuestionamientos a la historia que se postula como ciencia, en cambio la novela histórica se arroga el derecho a liberarse de ese problema y encarar la reescritura de la historia haciendo ostensible el presente de enunciación. Confrontar para esta problemática en la ciencia histórica: Jacques Le Goff, Pensar la historia. Modernidad, presente, progreso, Buenos Aires, Paidós, 1991, 15-31. 
experiencia de la última dictadura, la ficción diseña, por un lado, una "cartografía de la barbarie" que - descolocando la teleología del progresovincula procesos autoritarios de diversa índole; ${ }^{2}$ por el otro trama una red simbólica, un "imaginario de las dictaduras" que iremos analizando en las novelas.

Al mismo tiempo el presente se lee desde el pasado porque, de algún modo, la experiencia de la dictadura se percibe como un trauma que es necesario resolver. Así el pasado se vuelve el espacio para indagar sus causas o antecedentes o para saldar simbólicamente las deudas con las víctimas o realizar el duelo.

Además la ficción tolera más cómodamente la perspectiva del futuro a través de la utopía, más cercana a la invención que a las ataduras con lo "real" propias de la historia, aunque Heidegger sostenía que la historia no sería sólo la proyección por parte del hombre del presente en el pasado, sino la proyección en el pasado del porvenir elegido, una historia revelada, una historia deseo hacia atrás. ${ }^{3}$

En tercer lugar me interesa destacar como un perfil propio de la novela histórica el modo en que retoma y reflexiona sobre los temas vigentes en la posdictadura imprimiéndoles lo que puede llamarse una densidad panorámica. Por una parte, los debates de la posdictadura se recortan en una temporalidad más o menos precisa y limitada por la dictadura y las décadas anteriores. La novela histórica abre esos temas y problemas a nuevos contextos, a otros períodos y momentos del pasado.

2 Por otra parte, la novela histórica pone en práctica una serie de operaciones frente al pasado a través de procesos de selección, recortes, ausencias concedidos por la matriz ficcional. También la historiografía elige, ignora y selecciona pero lo hace con menos libertad, más culpa y al margen de las posibilidades simbólicas de la ficción. La novela histórica se ofrece como un campo liberado de las amarras, leyes y límites que la historia como ciencia se impone.

3 Comentado por Jacques Le Goff en Pensar la historia. Modernidad, presente, progreso, op. cit. p. 31. 
Esta posibilidad es el resultado de esa doble visión que señalamos en el punto anterior, y proporciona a las diversas problemáticas una densidad de significaciones no contempladas por la coyuntura que les dio origen. Este corrimiento y descolocación da lugar a la vez a una perspectiva que distancia el tema en cuestión, lo enajena, pero también acerca la historia, la vuelve de algún modo cómplice del presente. Por ejemplo, el "subversivo" como víctima de la última dictadura se vincula -corriéndose de lugar- con el indígena, víctima de otro sistema de dominación, pero a la vez esta conexión los acerca y resignifica recíprocamente.

Por último quiero señalar el carácter de práctica intelectual que el auge de la novela histórica adquirió a partir de las polémicas suscitadas por la publicación de ¡Bernabé, Bernabé! de Tomás de Mattos en varios semanarios y secciones culturales de los medios más destacados del Uruguay. La interacción entre pasado y presente es a la vez un inconveniente y una posibilidad para los historiadores quienes temen el peligro distorsionador que el presente puede ejercer sobre el pasado poniendo en cuestión la objetividad de la historia. Pero, por otro lado, es justamente esa interacción entre ambos tiempos la que articula la "función social" o lo que Habermas llama el "uso público de la historia" en beneficio de los requerimientos del presente. ${ }^{4}$ La novela de Tomás de Mattos logró una fuerte articulación con la esfera pública, instalando una serie de temas que reorientaron el sentido de los debates.

4 Mientas las posiciones de Le Goff y De Certeau articulan la labor historiográfica como una práctica que se realiza desde el presente, Habermas demanda el derecho por parte de los integrantes de la esfera pública de intervenir en dicha práctica. Dice John Torpey a propósito: "Excepto a través de una política totalmente tecnocrática, no hay manera de eliminar la participación de los ciudadanos en discusiones sobre temas en los cuales posean poca o ninguna competencia (...) Como ciudadano, el cientista social tiene el derecho, y también el deber, de intervenir en una controversia cientifica que tenga implicancias políticas". Cfr. Le Goff, Pensar la historia, op. cit, p. 12, 29-31; Michel de Certeau, La escritura de la historia, México, 1993, y John Torpey, "Habermas y los historiadores", en Punto de vista, año XII, no. 36, dic. 1989, Bs. As. 
Estas son las principales hipótesis con las que indago el funcionamiento de la novela histórica en el tejido de la posdictadura y de las que parto para el análisis de cada novela.

El primer capítulo "Crisis y revisión de la identidad uruguaya" es un panorama general sobre los cambios en el campo intelectual que permiten pensar las significaciones y alcances de la posdictadura como un nuevo lugar de enunciación.

En el segundo capítulo, "La épica de los orígenes", el análisis del ciclo de novelas históricas escritas por Eduardo Acevedo Díaz en la segunda mitad del siglo XIX resulta una necesaria aproximación a sus cuatro novelas para marcar las diferencias con las de la posdictadura.

"BBernabé, Bernabé! de Tomás de Mattos o las nuevas cartografías de la historia", el tercer capítulo, analiza el quiebre de esa épica fundacional y su sustitución por una lectura a contrapelo, que enhebra los diversos momentos en que se implementaron políticas autoritarias en la historia uruguaya.

El cuarto capítulo "Las identidades olvidadas (La fragata de las máscaras de Tomás de Mattos)" se vincula con el capítulo anterior en cuanto ambas novelas recuperan "identidades ausentes" en la comunidad uruguaya. Si ¡Bernabé, Bernabé! se ocupa del exterminio de los charrúas, La fragata de las máscaras se centra en la "visión de los negros".

"Variaciones de la memoria" explora las diversas propuestas en torno a la necesidad de recuperar la memoria durante el gobierno constitucional de Sanguinetti, promotor de la política del olvido ("los ojos en la nuca"). El príncipe de la muerte de Fernando Butazzoni se presenta como una compleja reflexión sobre la memoria y el secreto en la historia uruguaya. 
En el sexto capítulo "Los archivos de la vida privada" abordo a partir de El archivo de Soto de Mercedes Rein y de Una cinta ancha de bayeta colorada de Hugo Berbejillo los nuevos espacios privilegiados para encarar la relectura de la historia de la violencia y los crímenes durante la dictadura de Latorre, así como la necesidad de desarticular los monumentos nacionales.

En el séptimo capítulo exploro el giro que Artigas Blues Band de Amir Hamed imprime a la novela histórica desde la propuesta de la "retroescritura" como nuevo modo de leer el pasado.

Las tensiones entre historia y ficción, los nuevos pactos de lectura y los rasgos estéticos encarados en el cierre me permiten establecer relaciones entre todas las novelas.

El orden seguido no es azaroso, elegí introducir con cada capítulo y a partir del análisis de una novela alguna problemática relevante para el desarrollo de las hipótesis y sólo hacia el final indago las posibles correspondencias. 


\section{CRISIS Y REVISIÓN DE LA IDENTIDAD URUGUAYA}

\section{1-La posdictadura como un nuevo lugar de enunciación}

Me interesa abordar la posdictadura como una matriz crítica que se hace cargo de una serie de conflictos surgidos a partir de la experiencia dictatorial pero que también confronta con las políticas gubernamentales que digitaban la transición. Dada la magnitud y complejidad de este marco, lo acotaré a las propuestas relacionadas con la novela histórica uruguaya.

En primer lugar, la posdictadura aparece como un nuevo lugar de enunciación en tanto articula una nueva agenda que analiza la experiencia de la última dictadura y sus herencias, aborda los problemas de la memoria y la justicia, revisa los sistemas autoritarios y los procesos democráticos, indaga las constituciones del estado/nación y sus políticas de exclusión, revisa los imaginarios de estas comunidades y los dispositivos identitarios, relee su historia para señalar sus antecedentes dictatoriales.

En el campo intelectual uruguayo estas cuestiones se evidenciaron en una serie de prácticas intelectuales que instauraron debates académicos, invadieron las revistas culturales y los semanarios recientemente abiertos como Cuadernos de Marcha y Brecha y los suplementos culturales de El País y La República, impulsaron la creación de revistas literarias como Graffiti o nuevas editoriales como Trilce, y organizaron discusiones en la esfera pública. La novela histórica fue parte de esta movida, palpable en las polémicas desatadas por la novela inaugural, ¡Bernabé, Bernabé! de Tomás de Mattos. 
Para citar sólo algunos ejemplos, en los inicios de la democracia se organizaron en Uruguay varios congresos y coloquios sobre el problema de la identidad, cuyos trabajos se han publicado en importantes compilaciones: Cultura(s) y nación en el Uruguay de fin de siglo, ed. $\mathrm{H}$. Achugar (1991); Identidad uruguaya: ¿mito, crisis o afirmación?, comp. H. Achugar y G. Caetano, (1992); Mundo, región, aldea. Identidades, politicas culturales e integración regional, comp. H. Achugar y G. Caetano, (1994). A esta lista, y sin intención de agotarla, se pueden añadir otros textos sobre los problemas encarados como el de Maren y Marcelo Viñar, Fracturas de memoria. Crónica para una memoria por venir, o los ensayos de $\mathrm{H}$. Achugar, en especial aquellos contenidos en $L a$ balsa de la Medusa, (1992).

En segundo lugar se modifican y renuevan los paradigmas que sirven de base para capturar y reflexionar sobre esa nueva agenda. De un modo general podemos sostener que las herramientas teóricas de la posmodernidad y del postestructuralismo, así como nuevas perspectivas sobre la nación, las alteridades y los imaginarios sociales entre otras, sufrieron un proceso de recontextualización para poder repensar la "realidad" luego del quiebre de la dictadura.

Pero fue especialmente la presencia de cierta vertiente del debate sobre la posmodernidad en las costas uruguayas la que dio pautas para pensar la reorganización de estas recientes democracias y un marco conceptual para la revisión del discurso de identidad nacional.

El imaginario batllista, elaborado durante las primeras décadas del siglo XX, diseñó un conjunto de características con las cuales se identificaba la comunidad uruguaya en base a valores propios de una nación democrática, moderna, culta y cosmopolita, emblematizados en "La Suiza de América", "La Atenas del Plata", "El campeón cultural de 
América". Este mundo de ideas se fracturó con la última dictadura militar $\mathrm{y}$, en menor escala, con el ingreso del Uruguay al Mercosur.

La década de la dictadura rompió con la continuidad histórica del Uruguay, al tiempo que entraron en crisis tanto la convicción de constituir una sociedad democrática como muchos otros valores que sustentaban una imagen colectiva autocomplaciente. Esta fractura reordenó la historia del Uruguay que postulaba su origen en la edad dorada del batllismo, a fin de encontrar los antecedentes de la barbarie militar en el convulsionado siglo XIX.

La presencia del Mercosur puso en juego una reestructuración del espacio territorial que hizo insostenible la idea de "nación" como categoría válida ante la acentuación de los particularismos y las diferencias, y frente al fenómeno inverso de "globalización" promovido por las políticas de integración transnacionales. Ambos fenómenos desarticulan el discurso de identidad moderno, fundado en la idea de la nación como un todo homogéneo o integrado, en favor de la consideración de los particularismos de cada comunidad y de una apertura de las fronteras hacia la regionalización.

Junto al inicia de la democracia ingresó el discurso sobre la posmodernidad como un paradigma capaz de aportar categorías útiles para pensar la identidad nacional. El debate sobre la posmodernidad en ciertos pensadores de América Latina (Fernando Calderón, Norberto Lechner, José Joaquín Brunner, entre otros) y la recepción y resemantización de que fue objeto en diversas disciplinas coincidió, en parte, con el inicio de la posdictadura en el cono sur, y sirvió para reordenar en torno a él los significados de una democracia que deseaba superar el eterno retorno de los gobiernos militares.

Esta recontextualización implicó un desplazamiento de los debates occidentales sobre modernidad/posmodernidad. Por un lado, se 
trata de la descripción de una nueva época llamada alternativamente posmoderna, posindustrial, poscapitalista o massmediática, sintetizada de modo paradigmático por Daniel Bell 5 . Por el otro, la posible vigencia o caída de la modernidad provoca diversas interpretaciones entre aquellos que rescatan la validez aún perdurable de ciertos principios insertos en el proyecto moderno (Habermas) ${ }^{6}$ y otros que auguran el fin de un modelo que instrumentó las políticas autoritarias del nazismo, el stalinismo y las barbaries de la Segunda Guerra Mundial (Lyotard). ${ }^{7}$ Un buen número de posturas frente a la posmodernidad se deduce de la interpretación que cada autor haga de la modernidad y sus procesos.

Como sabemos, la modernidad colocó a la razón como norma de validez, sustituta del principio religioso en tanto eje ordenador del cosmos. Con ello provocó la autonomización de las esferas del saber en la ética, la ciencia y el arte que ahora se legitimaban en base a sus propios principios. Casi todos los autores coinciden en este punto de partida descrito por Max Weber, retomado por los pensadores de la Escuela de Frankfurt y sintetizado por Habermas. Este proyecto -que Habermas contemplaba como el equilibrio entre las diversas esferas y su mutuo control, así como la posibilidad de que estos saberes se plasmasen en la cotidianeidad social- se desvió de sus cauces originales colocando a la razón emanada de las ciencias y al servicio del progreso tecnológico por encima de los intereses ajenos a ella y sofocando la cotidianeidad social del individuo. Éste se vio sometido por tal razón instrumental que se institucionalizaba principalmente en las burocracias estatales.

5 Bell, Daniel, El advenimiento de la sociedad post-industrial, Madrid, Alianza, 1994.

6 Habermas, J., El discurso filosófico de la modernidad, España, Taurus, 1989 y "Modernidad: un proyecto incompleto", en AAVV, El debate modernidad/posmodernidad, comp. N. Casullo, Bs. As., Pontosur, 1989.

7 Lyotard, J-F, La condición posmoderna, Bs. As., 1987. 
Desde diversas posturas críticas se asigna a los procesos racionalizadores propios de la modernidad el origen de varios de los males que se efectivizaron en la historia occidental, en especial el auge de los totalitarismos, la emergencia del racismo como ideología, la barbarie de las Guerras Mundiales. Si la modernidad provocó por un lado la separación de las esferas del saber, por el otro intentó diagramar normas racionales -y por lo tanto de validez universal- que originaron los grandes metarrelatos que prometían la salvación y el progreso de la humanidad. Tales "proyectos modernos", fundamentados en una visión de la sociedad como totalidad y de la razón como principio universal, desembocaron en sistemas políticos autoritarios y actos históricos signados por la barbarie.

Esta descripción simplificada de la modernidad y sus consecuencias históricas es interpretada de diverso modo, dando origen a formulaciones encontradas. Si la modernidad se sustentó en la razón, los principios universales, la categoría de "totalidad", el progreso, la utopía, los metarrelatos abarcadores, y fueron ellos los que enmascararon y suscitaron las políticas bárbaras, entonces -razonan algunos- es hora de desacreditar de una vez por todas aquellos principios, dar por concluida la modernidad y proponer nuevos modos de comprender esta nueva etapa que se avecina -la posmodernidad- en base a otros principios. Se abre un amplio espectro de posturas que van desde un radicalismo sustentado en la negación de la modernidad como un todo y el inicio de la posmodernidad como nueva etapa, hasta aquellos que intentan volver a rever el proceso modernizador con una mirada crítica capaz de señalar sus errores y reformular sus posibles aciertos.

Desde una posmodernidad entendida como una revisión de los parámetros modernos, se lleva a cabo no sólo una crítica de aquellas categorías que estructuraban la modernidad, sino que además se proponen nuevas instancias capaces de sortear los escollos de las antiguas políticas autoritarias, tales como la sustitución de metarrelatos 
por "pequeños relatos", la atención a los reclamos de las minorías y la consideración del problema de la alteridad en sus múltiples vertientes de clase social, orientación sexual y etnicidad.

Este debate modernidad/posmodernidad se articula en América Latina privilegiando ciertos temas, autores y enfoques que lo diferencian de las discusiones elaboradas en Europa y EEUU. En los paises centrales, puede generalizarse, el eje lo constituye la necesidad de describir una sociedad -llamada alternativamente posmoderna, posindustrial, poscapitalista o massmediática- que ha abandonado los moldes del modelo moderno, industrial y capitalista por un nuevo orden basado en la producción de servicios, la preeminencia del sector profesional y técnico, y la creación de una nueva tecnología intelectual. En América Latina, por el contrario, el foco principal es la redefinición de la "modernidad latinoamericana" en desmedro de posibles caracterizaciones de elementos de una sociedad posindustrial que difícilmente se encontrarían en estas latitudes. De allí que se privilegie a un autor como Habermas. Se trataría de leer en clave latinoamericana el "proyecto incompleto" de la modernidad tal como se realizó en América Latina. ${ }^{8}$ A este fin se

8 Sobre los debates en torno a la posmodernidad en el cono sur me refiero a cierta vertiente cuyos autores y publicaciones son las siguientes: Brunner, José J., "Notas sobre la posmodernidad y lo moderno en la cultura latinoamericana", en: David y Goliath, Bs.As., año XVII, $\mathrm{n}^{\circ}$. 52, 1987; Cartografias de la modernidad, Santiago de Chile, 1994; "Entonces ¿existe o no la modernidad en América Latina?", en: Punto de Vista, Bs. As., año X, $\mathrm{n}^{\circ}$. 31, 1987; Calderón, Fernando, "América Latina: Identidad y tiempos mixtos", en: David y Goliath, op. cit.; García Canclini, Néstor, "¿Un debate entre tradición y posmodernidad?; Antropología versus sociología", en David y Goliath, op. cit.; Culturas Hibridas. Estrategias para entrar y salir de la modernidad, Bs. As., Editorial Sudamericana, 1992; "Los estudios culturales de los 80 a los 90: perspectivas antropológicas y sociológicas en América Latina", en Punto de Vista, Bs. As., año XIV, $\mathrm{n}^{\mathrm{o}}$. 40, jul/set., 1991; Hinkelammert, Franz, "Frente a la cultura de la posmodernidad: proyecto político y utopia", en David y Goliath, op. cit.; Lechner, Norbert, "Un desencanto llamado posmodernidad", en: Punto de Vista, Bs. As., año XI, no. 33, 1988; Richard, Nelly, "Periferias culturales y descentramientos posmodernos, marginalidad latinoamericana y recompaginación de los márgenes", en Punto de Vista, Bs. As., año XIV, nº. 40, jul/set., 1991; Schmucler, Hector, "Los rostros familiares del totalitarismo. Nación, Nacionalismo y pluralidad", en: Punto de Vista, Bs. As., año XI, nº.33, set/dic. 1988; VVAA, Cultura 
privilegian, de la caja de herramientas teóricas de la posmodernidad, dos propuestas:

-las estrategias que permiten llevar a cabo una crítica a la modernidad latinoamericana.

-las categorías que posibilitan volver a diseñar hoy una modernidad más acorde con los principios democráticos.

Ambas se imbrican en un común intento por salvar los procesos modernizadores de sus rasgos no deseados y desembocan en un nuevo discurso de identidad latinoamericana. Podemos apuntar algunos aportes de esta discusión.

La atención a la pluralidad y heterogeneidad, que la posmodernidad ha provocado con su crítica a una supuesta plenitud y univocidad del sujeto moderno, ha ahondado en el carácter heterogéneo de la sociedad y cultura latinoamericanas como datos constitutivos de su identidad. Esta diversidad remite a sus orígenes históricos. Surgida del choque de, fundamentalmente, dos sistemas sociales y culturales, el indígena y el español, América Latina se fue conformando a partir de las disímiles relaciones que entre ambos existían y de la posterior evolución que sufrieron. La Independencia y los consiguientes procesos modernizadores no impidieron una relación de dependencia económica con los países centrales que se tradujo muchas veces en intentos por integrar la diversidad social con modelos políticos que favorecían a ciertos sectores hegemónicos en desmedro de otros, profundizando las diferencias y desigualdades sociales, étnicas y culturales. Estas cuestiones

Mercosur. Politica e industrias culturales, Montevideo, Trilce, 1991; Cultura(s) y nación en el Uruguay de fin de siglo, Montevideo, Trilce, 1991; Identidad uruguaya: ¿mito, crisis o afirmación?, Montevideo, Trilce, 1992; Mundo, región, aldea. Identidades, políticas culturales e integración regional, Montevideo, Trilce, 1994. 
-presentes en la tradición intelectual latinoamericana- recibieron un nuevo impulso a partir del enfoque posmoderno poniendo un renovado acento en el carácter plural de la sociedad latinoamericana y en las relaciones de poder que privilegiaron prácticas irrespetuosas de las diferencias.

La discusión sobre la posmodernidad en América Latina sumó críticas a los modelos de democracias autoritarias basadas en la ausencia de un consenso compartido ampliamente -difícil de conseguir dada la desigualdad y diferencia de los sectores-, suplido por la imposición de un proyecto integrador que anclaba en una unidad nacional, en buena medida ficticia. Cuando la democracia ha fallado en este intento fueron -en ciertas ocasiones- las dictaduras las que impusieron tal unidad.

En este sentido las reflexiones en torno a la posmodernidad son un llamado a repensar un nuevo modelo de democracia, atento a la pluralidad y a los consensos locales a fin de lograr la participación. Funciona, entonces, como una posibilidad de diluir los resabios autoritarios de las modernidades latinoamericanas. (Brunner: 1987; Lechner, 1988)

Los dos polos que se privilegian en esta discusión son, por un lado, las tesis posmodernas -el más citado suele ser Lyotard- en torno a la caída de los metadiscursos legitimadores de prácticas políticas, el abandono de la noción de totalidad como instancia referida por las ideologías fuertes y la sustitución de ambos por un nueva visión del campo social y cultural ahora disgregado por múltiples y heterogéneos sujetos. Aquello que se deja de lado de las tesis de Lyotard y de la posmodernidad en general es su radicalidad que puede desembocar en la incapacidad de desarrollar un "proyecto" de corte moderno, el desdibujamiento completo de las diferencias de clases sociales vigentes 
aun en América Latina y el más que discutible concepto de posthistoria que imposibilitaría proyectar el futuro.

Incluso se critican las posiciones de una posmodernidad radical que en su negación total a la racionalidad iluminista descarta con ella sus derivaciones más positivas hacia los derechos humanos, la noción de igualdad, la racionalidad comunicativa, etc. Reformular la modernidad para América Latina no implica -para algunos- sacarla de su marco racional (Hinkelammert, 1987). En esta línea se privilegian las propuestas de Habermas tendientes a rectificar el proyecto moderno por medio del respeto a la heterogeneidad del cuerpo social. Predomina una perspectiva constructiva en el uso que hacen de los aportes de la posmodernidad aplicados a América Latina. Desde luego que no todos coinciden en las mismas propuestas para reorganizar las transiciones. En Chile, por ejemplo, mientras FLACSO buscó los modos de conducir los procesos democráticos a través del "consenso" y la "negociación" de las partes escindidas del cuerpo social, Nelly Richard se opuso a estas alianzas eligiendo una suerte de margen extremo y siempre desarticulante, de allí que prefiera la deconstrucción derrideana como matriz organizativa de su lugar de enunciación y la estética hipervanguardista de la "avanzada". Prefiere salirse de la lógica de la racionalidad, tanto de la derecha como de la izquierda tradicional y nueva, para tejer una topología del margen como "dislocación", "rotura", "discontinuidad"o "errancia". .

Las prácticas democráticas en América Latina son criticadas por el intento de las élites gobernantes de imponer una idea de nación homogénea y un proyecto político que favorecía los procesos de homogeneización como única vía de integración (Lechner, 1988). El actual marco ofrece nuevos modos de integración social que tengan en

9 Cfr. Nelly Richard, La estratificación de los márgenes, Santiago de Chile, Francisco Zegers, 1989 y La insubordinación de los signos, Santiago de Chile, Cuarto Propio, 1994. 
cuenta la diversidad de los sectores y procuren acordar los reclamos de cada parte. Atender a los conflictos y tensiones sin acudir a soluciones drásticas es una de las propuestas que evidencia este giro interpretativo.

La crítica a la noción de totalidad se aplica en América Latina para señalar un dato constitutivo de su sociedad entendida ahora como plural pero donde no se descartan otras formas integradoras: "Lo anterior llevaría por tanto a pensar nuestras sociedades como sociedades sin consenso básico, sin acuerdo sobre fundamentos, en consecuencia con escasa posibilidad (y necesidad) de pensarse como totalidades, donde más que consenso se requiere organizar el conflicto y dar lugar a concentraciones de intereses, y donde más que recuperar un orden político legitimado por un núcleo de valores se construya otro -necesariamente inestable- que refleje acuerdos sobre reglas de gobierno" (Brunner; 1987). Más que una crítica a la noción de totalidad, ahora reformulada bajo la modalidad de una institución colectiva que se haga cargo de los diversos sectores, se trata de una puesta en crisis de los "totalitarismos" y su versión latinoamericana de la Doctrina de la Seguridad Nacional, que propone una utopía de salvación implementando una "solución final" a través del terrorismo de estado para erradicar definitivamente todo terrorismo (Hinkelammert, 1987).

De este modo, estas reapropiaciones de las perspectivas posmodernas sólo se pueden comprender en el peculiar contexto democratizador de los ochenta y los noventa que imponía la urgente necesidad de superar las últimas y quizás más violentas dictaduras militares y diagramar las democracias posibles.

La exégesis de las experiencias autoritarias anteriores -y aquí la tendencia consiste más en marcar las similitudes que diferencias entre las democracias autoritarias y los gobiernos militares- podría poner fin a lo que se perfilaba como un destino inevitable en América Latina. No sólo 
se consideró la doctrina de la Seguridad Nacional como el intento de imponer una ideología de corte totalitario, sino que algunos criticaron también las ideologías revolucionarias de los sesenta y setenta que desembocaron en enfrentamientos armados. Ante el predominio en aquellas décadas de ideologías fuertes, Lechner presenta ahora el "desencanto político" propio de la posmodernidad como una vía para repensar la política latinoamericana, constituyéndose en un claro ejemplo de las apropiaciones de la posmodernidad -categorías como heterogeneidad, pluralidad, diferencia son utilizadas no para dar por finalizada la modernidad, sino para "desarrollar el proyecto de modernidad" atento a un "referente colectivo" y nuevos modos de integración social. Asimismo, no se trata de renegar completamente del futuro y del progreso e instalar en su lugar la posthistoria, sino de criticar concepciones historicistas que hacen del futuro el lugar de la redención alcanzable por las prácticas revolucionarias o por el terrorismo de estado. La idea de revolución o redención que permeó a los dos sectores que se enfrentaron en los setenta debe ser sustituida por la de reforma. (Lechner, 1988).

El "desencanto" corre parejo con el proceso moderno de secularización -en términos de Max Weber- y Brunner lo utiliza para reinterpretar los autoritarismos latinoamericanos que significarían un reencantamiento y contra-secularización. Frente a las crisis de integración por las que ha pasado América Latina, sacudida por las contradicciones, tensiones y conflictos productos de su desigualdad, han surgido como reacción propuestas que ofrecen superar los desencuentros apelando a los símbolos de lo nacional en tanto ritos de integración. Estos símbolos pueden ser movilizadas por partidos políticos, las FFAA, élites intelectuales, grupos revolucionarios, líderes carismáticos, iglesias o sectas e implican una estructura "cuasi religiosa". La secularización permitiría una política liberada de rasgos omnipotentes, principios 
absolutos e ideologías mesiánicas y, más atenta a sus posibilidades instrumentales y a sus capacidades para "negociar" los conflictos.

Desde ya que no todos coinciden en las ideas anteriormente expuestas, basta pensar en la emergencia de nuevos grupos de protesta (algunos surgidos ya durante la dictadura) que como Las Madres de Plaza de Mayo se colocan en posturas más combativas.

Esta descripción de los ejes del debate sobre la posmodernidad en América Latina, y más especialmente en el Cono Sur, resulta indispensable como marco para interpretar las reflexiones que se llevaron a cabo en el campo intelectual uruguayo y las propuestas de las novelas históricas de la posdictadura.

Las críticas a las políticas de la violencia estatal, a las dictaduras y a la modernidad autoritaria se desarrolla en las novelas a partir de la reescritura de fundamentalmente dos momentos de la historia del siglo XIX: el origen de las guerras de la Independencia es leído a partir del genocidio de los charrúas y el proceso modernizador, a partir de la dictadura de Latorre y Santos.

La reformulación del discurso de identidad, atravesado ahora por la percepción de la "débil heterogeneidad" uruguaya, sostiene las dos novelas de Tomás de Mattos que capturan las identidades de los charrúas y de los negros.

El cuestionamiento de los metarrelatos y la puesta en crisis de los imaginarios autocomplacientes de los uruguayos es crucial en la totalidad del corpus. De igual modo se percibe una atención particular a la pluralidad de puntos de vista, al abandono de las certezas contundentes, a la tolerancia ante los disensos y a la búsqueda de consensos parciales, pero no se diluyen algunos perfiles revolucionarios propios de la tradición latinoamericana. 
Tal contexto sólo constituye un telón de fondo y a medida que abordemos el análisis particular de las novelas, estos planteos adquieren matices originales, aristas no previstas que le dan cuerpo desde la perspectiva individual de cada autor. Por ejemplo Tomás de Mattos adhiere a muchas de estas ideas, pero lo hace desde su herencia cristiana, mientras Amir Hamed las reorganiza desde el cruce entre postestructuralismo y una estética neobarroca. 


\section{Fracturas y revisiones del discurso de identidad}

Las coordenadas brevemente consideradas -el inicio de la democracia y el paradigma posmoderno- conformaron la matriz que articuló la revisión y reformulación del discurso de identidad en el Uruguay de la posdictadura.

Un renovado marco categorial se evidencia en el momento de señalar los parámetros que inciden en la definición de la identidad y su relación con los imaginarios sociales. Por un lado se arremetió contra toda versión esencialista de la identidad, apuntando al carácter procesual de la misma. Se insiste en la índole de "constructo" e "invención" de todo imaginario, lo que facilita su crítica. En esta línea los trabajos de Benedict Anderson, Ernst Gellner, Eric Hobsbauwm, Pierre Nora y Homi Bhabha contribuyeron a poner en foco la dimensión simbólica de la nación. ${ }^{10}$ Por el otro se comienza a hablar en plural de las "identidades", en un gesto inclusivo que se vuelve al pasado para rescatar aquellas comunidades excluidas de los proyectos estatales.

\subsection{A la deriva...}

El problema evidencia la crisis de los imaginarios con que los uruguayos se identificaban. Ciertos textos intentan capturarla: La balsa de la Medusa alude a una navegación que aún no ha llegado a un puerto seguro, en tanto Identidad uruguaya, ¿mito, crisis o afirmación? ahonda el problema desde la duda y la interrogación. Se percibe una tendencia

10 Cfr. Gellner, Ernest, Naciones y nacionalismo, Bs. As., Alianza Editorial, 1983; Anderson, Benedict, Comunidades imaginadas. Reflexiones sobre el origen y la difusión del nacionalismo, México, FCE, 1993; Hobsbauwm, E. J., Naciones y nacionalismo desde 1780, Barcelona, Editorial Crítica, 1992; Nora, Pierre, Les Lieux de Mémoire, París, Gallimard, 1984; Bhabha, Homi, "Introduction: narrating the nation", en: Nation and Narration, New York, Routledge, 1995. 
que valora positivamente la duda y la incertidumbre como reacción, podemos proponer, ante las certezas de las ideologías fuertes de las décadas de los sesenta y los setenta.

Las críticas apuntan, fundamentalmente, a los finales del siglo XIX cuando comenzaron a perfilarse los rasgos característicos del Uruguay moderno, surgido con el pacto neocolonial, según Halperin Donghi. Ante los nuevos desafíos se proyectó una nación que perfilaba el primer modelo acabado de la identidad uruguaya. Batlle y el batllismo consolidaron el proceso identificatorio a partir de la definición de un nuevo modelo integrador ante la inmigración europea masiva, el "crisol de razas", que procuraba diluir las diferencias culturales a través, fundamentalmente, de la educación común y la participación política; un marco nacional de desarrollo; una profunda transformación de las estructuras del estado, la formación del sistema partidario moderno acompañado por el desenvolvimiento de una cultura democrática y la emergencia de un nuevo orden social. Se creaban así las condiciones para establecer una identificación de la nación con la comunidad política, que se expresaba en el estado representativo.

Estos procesos fueron conformando un imaginario anclado en las ideas de progreso, la marcha victoriosa del país con el desenvolvimiento de su riqueza; en la importancia de las instituciones democráticas y liberales; en la peculiaridad uruguaya diferenciada de América Latina, ya que carecía de un fuerte legado colonial y donde no existía una cultura indígena capaz de oponer resistencias a la civilización. Ello facilitaba su "cosmopolitismo", que lo acercaba a la cultura europea, y la integración social.

Si bien este reconfortante imaginario batllista fue discutido y sufrió ciertas crisis, su perduración y hegemonía durante tantas décadas 
mostró su profundo arraigo. De allí provinieron tópicos como "La Suiza de América", "La Atenas del Plata", "El campeón cultural de América".

La última dictadura militar rompe la continuidad histórica, asestando un golpe mortal a la autocomplacencia de los uruguayos en sus valores democráticos. La fractura reordenó la historia del Uruguay, que postulaba su origen en la edad dorada del batllismo, a fin de encontrar los antecedentes de la barbarie militar. Cambio de foco que ahora sitúa su mirada en el siglo XIX como lugar de origen de las políticas de la violencia: el etnocidio charrúa, el militarismo de Latorre, las guerras civiles. Puesta entre paréntesis de los alcances del gobierno de Batlle que ahora se presenta como un corte, una excepción entre dos momentos históricos vinculantes. "El desenlace de la crisis uruguaya expresado en el golpe de estado - dice Gerardo Caetano- había cobrado una significación que trascendía los límites del país. Tal vez como en pocas oportunidades, el Uruguay quedaba asimilado a la pulsación dramática de América Latina y, en apariencia enterraba su "singularidad" de la que tantas veces había hecho caudal." "

Estos análisis establecen nuevas articulaciones con lo "latinoamericano". Uruguay, "La Suiza de América", "país cosmopolita, de raíz europea, a salvo de los males que siempre aquejaron a los vecinos latinoamericanos" ahora encuentra un lazo firme, la dictadura militar, que lo emparienta con sus vecinos del cono sur en una historia compartida.

La particular focalización de varias novelas históricas en el siglo XIX obedece, en parte, a este intento por buscar un origen de la dictadura militar en el convulsionado siglo anterior.

11 Caetano, Gerardo y José Rilla, Historia contemporánea del Uruguay. De la Colonia al Mercosur, Montevideo, Fin de Siglo, 1994, 255. 


\subsection{El origen como contrautopia}

El lugar del "origen" se construye como tal desde diversas coyunturas históricas. En la historia uruguaya se han alternado dos orígenes, el de la "orientalidad" y el de la "uruguayidad". El primero, surgido durante la segunda mitad del siglo XIX, compartido y disputado entre blancos y colorados, apuntaba fundamentalmente a las guerras de independencia. Con posterioridad alcanzó otros usos, entre los cuales se encuentra la reapropiación que la última dictadura hizo de la "Orientalidad" en los festejos del Sesquicentenario de 1825."2

El origen de la "uruguayidad" emerge a fines del siglo XIX y comienzos del XX y culmina en el batllismo, como modelo progresista, democrático y liberal. Esta perspectiva coloca al convulsionado siglo XIX en una prehistoria violenta bajo el imperativo de consolidar la nación moderna. El significado que aquí se otorga al "origen" está determinado por la necesidad de fortalecer los valores democráticos y progresistas, relegando al desván de la prehistoria aquello que no encaja en el modelo. Esta perspectiva ignoró el etnocidio charrúa y la herencia colonial a fin de filiarse con lo europeo.

El impacto de la última dictadura en un país hispanoamericano que se enorgullecía de una notable continuidad democrática, provocó un giro en el significado mismo del término "origen", a través del rechazó tanto de la "orientalidad" esgrimida por la dictadura, como de la "uruguayidad" en la que ya nadie creía. Ahora se trataba de encontrar el origen de la violencia del estado invirtiendo la narración, reescribiendo la prehistoria del siglo XIX como historia, colocando en el inicio de la nación-estado el etnocidio charrúa, seguido por las guerras fraticidas y el militarismo de Latorre. Este es el eje preferido por un amplio número de

12 Cfr. Cosse Isabela y Vania Markarian, 1975: Año de la Orientalidad. Identidad, memoria e historia de una dictadura, Montevideo, Trilce, 1996. 
novelas históricas, como analizaremos más adelante. El origen se vuelve, entonces, una contrautopía a la cual es necesario regresar por su poder demoledor.

Achugar rescata un "relato olvidado" (ficticio) sobre el origen del Uruguay que combina rasgos de una utopía con otros de contrautopía. El relato consigna que Utopo "antes de establecerse en el cuarto creciente de luna que vendría a ser conocido como la isla de Utopía, visitó estas tierras nuestras, todavía deshabitadas, al oriente del río Uruguay. Dicen también que decidió no establecer en estas orillas su reino por estar demasiado cerca de otras mucho más ricas y extensas y no tener el gigantismo adecuado a su ilusión. Dicen, además, que a pesar de todo regó ríos, arroyos, cañadas, bañados (...) con unas extrañas semillas que producen sueños perseverantes y alucinaciones perversas (...) Sueños de grandeza y, sobre todo, aspiraciones a fundar sino un país, un Estado perfecto" ( $B M, 11$ ). La utopía no fundada en el territorio uruguayo, arraigó sin embargo en la mente de sus pobladores. Invertir los términos y crear una "pequeña utopía" más acorde a la realidad es la propuesta de $\mathrm{H}$. Achugar, que responde a las típicas reapropiaciones que desde América Latina prefieren diluir posturas extremas, privilegiando una crítica fuerte al mesianismo utópico pero sin disolver la posibilidad de una utopía que proyecte el futuro.

Achugar describe como otro de los orígenes posibles del Uruguay el momento en que "los míticos charrúas" están "comiéndose a Solís" $(B M, 34)$. De este modo vuelve a elegir otro relato, ahora histórico, que evita un comienzo prestigioso. Podríamos decir, siguiendo a Foucault, que Achugar sustituye la idea de "origen elevado" por la de los "inicios bajos", en los que el acto antropófago es el punto inicial de una historia que culminará con la dictadura del 73 , signando el decurso del devenir histórico. Achugar da las pautas para una nueva narración de la historia nacional pero operando con estrategias contrarias al intento canónico del 
género, prefiriendo una "desarticulada narración posmoderna": "Uruguay nace con un acto de violencia mayor, nace con un acto de antropofagia (...) En todo caso, nuestra historia -como muchas de América y Europa y del resto del planeta- se basa en la violencia" ( $B M ., 34)$.

\subsection{Los desvelos del Mercosur}

El Mercosur aparece para los uruguayos como el disparador de una crisis que pone al descubierto varios temores. Provoca un violento proceso que yo llamaría de "desnudamiento", quitarse las vestiduras imaginarias con las cuales los uruguayos lograban superar la pequeñez de su país a través de filliaciones con lo europeo y una negación de parentesco con los latinoamericanos. Su "singularidad" borraba el menoscabo del tamaño, reinstalado de modo contundente por el Mercosur.

En principio éste aparece como un proyecto impuesto desde afuera y ante el cual Uruguay no tiene más alternativa que plegarse. Tal situación trae temores e incertidumbres y genera un extenso debate que procura resguardar al país de una peligrosa relación con los vecinos, Brasil y Argentina. Frente a la integración fundamentalmente económica y política que propone el Mercosur, un grupo de intelectuales promovió la discusión en torno a las implicaciones culturales de ella, creando, incluso, el término de "cultura Mercosur".

Achugar comenta el imaginario sintetizado en la frase "lo pequeño es hermoso" que ha dado lugar a la "mentalidad del petizo", signo del complejo de inferioridad ante sus vecinos gigantes, y disparador de una serie de imágenes compensatorias ("El extracto viene en frasco chico", "Chiquito pero potente" o "Como el Uruguay no hay", $B M, 18$ ). Descubre también detrás de la frase "el campeón cultural de América", 
una cultura periférica: "la periferia de otras periferias; Buenos Aires, en definitiva también está en los márgenes del primer mundo".

El Mercosur replantea la relación con lo latinoamericano y lo europeo. Se abandona una óptica que buscaba filiaciones con lo europeo a través del mundo de las ideas y que veía al Uruguay como cuna de la cultura a favor de una perspectiva que debe atender necesariamente a las relaciones políticas y de mercado para encarar los problemas culturales. Estas posturas dejan de lado la concepción espiritualista de la cultura para abocarse a los aspectos materiales de la industria cultural y al mercado, sustituyendo la categoría de "bellas letras" a favor de la implementación de adecuadas políticas culturales.

La incorporación al Mercosur pone en juego una reubicación del territorio. La idea de "nación" se reformula ante la doble y contrapuesta presencia de los particularismos y de la "globalización que incluye al Uruguay en el proyecto del Mercosur. Se disputa también la centralidad de Montevideo como eje de las políticas culturales que ahora marcan otras zonas que, como la frontera norte, requieren revisar la política lingüística para aceptar el "portuñol".

Surge el temor de ser fagocitados por los poderosos mercados culturales de Argentina y Brasil, pero al mismo tiempo se evitan actitudes paternalistas que puedan desembocar en algún tipo de folclorismo protector de los productos locales. Las propuestas de integración intentan mediar entre el rescate de las subculturas y la globalización del mercado, armonizar el difícil equilibrio entre la necesidad de preservar la cultura e identidad uruguaya $\mathrm{y}$, al mismo tiempo, establecer vínculos dinámicos con la cultura de los países vecinos. Los nuevos públicos "regionales" imponen la selección de aquellos productos que les sean accesibles, favoreciendo las estéticas que sorteen los códigos demasiado particulares y privilegien ciertos rasgos "universales". El ejemplo paradigmático 
puede ser el de Jaime Roos quien, sin renuncia a la estética del candombe y la murga, la reactualiza al mezclarla con el rock.

\subsection{La "débil heterogeneidad"}

Una consideración hacia las subsociedades -de variado tipoinsertas en la comunidad uruguaya intenta rescatar y respetar las "diferencias" y "heterogeneidades" culturales a través de nuevos modos de integración social. El imaginario ahora acentúa la convivencia de los diferentes sectores a través de reclamos pacíficos. La participación comunitaria sustituye cualquier imagen de una clase social con poderes revolucionarios/redentores o la figura del padre (militar) que viene a poner la casa en orden. La democracia aparece como el principio ordenador del vínculo social.

Se critica el modelo de una nación homogénea, fundamento de las políticas del siglo XIX y XX, que facilitaron prácticas autoritarias (desde las campañas de exterminio de los indígenas bajo el imperativo de la civilización; la ideología del "crisol de razas" que diluía las diferencias traídas por los inmigrantes; hasta la doctrina de la Seguridad Nacional y los golpes militares como modos violentos de integración forzosa de los diversos sectores sociales. Achugar retoma estas propuestas para hablar de una "débil heterogeneidad de nuestro país" que permita la coexistencia de la pluralidad de subculturas y la formación de una "pequeña gran cultura" desde la multiplicidad "tolerante y democrática" $(B M, 36)$.

En este marco Teresa Porzecanski considera tendencias significantes en la década de 1980, que reinstalaron el tema de la "indianidad" y la "africanidad", generalmente ignorados en la conformación de la identidad uruguaya y que ahora "alientan una intencionalidad más dirigida que antes a habilitar un espacio indio y 
protagónico en la(s) nueva(s) versión(es) de la historia nacional".. ${ }^{13}$ Estos aportes -provenientes tanto del discurso científico como del literarioconstituyen para la autora "mitologías de ausencia" en tanto son "construcciones ficcionales tendientes a hacer notar un lugar vacío dentro de la elaboración de una identidad incompleta y no exenta de culpa". Tales mitos revelan "la imperiosa necesidad de reconstruir una identidad mestiza para el país" que lo acerque a América Latina. Se trataría, en definitiva, de una "reivindicación de Uruguay como país pluriétnico y plurirreligioso" que fragmenta el concepto unitario de una identidad nacional homogénea.

\subsection{El "diálogo controversial"}

Los anteriormente citados coloquios y posteriores compilaciones (organizados en los comienzos de la democracia) no sólo se abocan a la tarea de problematizar la identidad uruguaya, discuten, además, el modo más adecuado en que este debate debe realizarse, las condiciones de su enunciación. Si la experiencia de la dictadura mostró los efectos paralizantes de un discurso que se impuso como la única verdad a la sociedad, obturando la libre expresión de la esfera pública, ahora se procura revertir esta situación. El debate resulta un contexto adecuado para una discusión que se quiere plural y tolerante..$^{14}$ La modalidad del coloquio no sólo implica per se una enunciación plural, sino que además en estos eventos los participantes han sido seleccionados teniendo en

13 Cfr. "Uruguay a fines del siglo XX: mitologías de ausencia y de presencia", en: Identidad uruguaya: ¿mito, crisis o afimación?, op. cit. p. 49-61.

14 Maren y Marcelo Viñar señalan como legado de la dictadura "la herencia perversa de aspirar a un saber unívoco y monolítico en que la divergencia es percibida como detestable y el interlocutor se vuelve abominable y abusivamente un otro, extraño o enemigo" y frente al cual proponen "la riqueza de un diálogo controversial". Cfr. Fracturas de memoria. Crónicas para una memoria por venir, Montevideo, Trilce, 1993, p.13. 
cuenta la diversidad de disciplinas, profesiones e instituciones -desde empresarios hasta poetas, pasando por especialistas en historia, en comunicación, agentes de instituciones estatales o privadas -en un marco que coloca en igualdad de condiciones la validez de cada opinión.

Estas tácticas pueden leerse como ensayos de los intelectuales por articular de un modo renovado su función en el campo cultural y social. La deconstrucción de los mitos fundantes de la nacionalidad uruguaya, la revisión de la idea de nación homogénea para advertir la presencia de diferencias, la reescritura de la historia a fin de encontrar los momentos de emergencia de prácticas autoritarias y violentas, las nuevas vinculaciones de Uruguay con América Latina conforman la actual agenda que intenta debatirse en el espacio plural del diálogo.

Los temas predominantes, las modalidades textuales, los cruces de disciplinas e instituciones de los sujetos puestos en juego para redefinir la identidad uruguaya privilegian una atención a la pluralidad, a la desjerarquización de los discursos, a la coparticipación de las instituciones, a un nuevo rol del intelectual. Se percibe una tendencia que valora positivamente la duda y la incertidumbre frente a la solidez de los grandes relatos y las verdades definitivas. La posdictadura invita a una rápida reconfiguración del lugar de aquellos intelectuales, sobre todo los de izquierda, que han presenciado -tanto a nivel internacional como localla caída de sus discursos y prácticas legitimantes. Estas perspectivas procuran sortear los implícitos que conlleva la univocidad como modelo de una práctica que desemboca en gestos autoritarios; proponen, por el contrario, diseñar un espacio de debate pluralista capaz de suturar sin violencia las fisuras sociales. Resultan marcos eficaces para hacer de la democracia participativa el eje ordenador de las prácticas culturales.

Las novelas históricas insisten en abrirse a esta pluralidad de puntos de vista sobre los hechos narrados con la inclusión de documentos 
oficiales, epístolas personales, partes de campaña, notas periodísticas que se yuxtaponen entre sí, diversificando la verdad histórica. ¡Bernabé, Bernabé! de Tomás de Mattos recurre a la "conversación" como ordenador de las diferentes voces, ingresando la versión de los charrúas en la configuración de los acontecimientos. El uso de heterónimos -el de Juana Caballero en la novela de Achugar Cañas de la India o la ficcionalización de la narradora Josefina Péguy en las dos novelas de Tomás de Mattos- hablan de una autoría que se escinde y busca compartirse.

La impronta posmoderna se traduce también en un posmodernismo literario que aboga por los cruces culturales. Los textos de Achugar explotan un tipo de ensayo "libérrimo" que desborda los márgenes de la escritura académica en el cruce de los más variados procedimientos pertenecientes a diferentes modalidades discursivas, desde la prosa poética, los núcleos narrativos, el análisis fillológico, hasta el zapping de los mass-media. Procuran escapar a la función normativa de la Academia y al canon moderno "belletrístico", en tanto ambos responden a un poder hegemónico. Achugar reformula la noción de "campo literario" e "institución arte" en La biblioteca en ruinas, atendiendo a los cambios producidos en la cultura de este fin de siglo y con el aporte de las categorías del posmodernismo. Lee el desarrollo de la historia literaria uruguaya desde el canon moderno basado en la "belleza paradojal" de Onetti, que incluye lo "bajo" pero no lo "ordinario", y que se propone como estética hegemónica. En cambio la actual "estética de la ordinariez", índice de la apertura de los márgenes del campo literario, permite el ingreso de los "otros", los heterodoxos y transgresores.

La actual "biblioteca en ruinas" acepta la contaminación entre los valores de la alta cultura, la cultura popular y la masmediática, el cruce de Madonna con Onetti. Todos estos factores contribuyen, para Achugar, al proceso de democratización de la cultura y en ello se advierte su 
postura "anti-apocalíptica" frente a los massmedia y los valores "vulgares".

Las estrategias brevemente esbozadas pueden leerse como ensayos de los intelectuales -en especial los de izquierda- por articular de un modo renovado su función en el campo cultural y social. Implican el abandono de una actitud, mesiánica recordarán algunos, tanto de resistencia hacia el estado como de apelación fuertemente ideológica, en favor de los posibles acuerdos con los diferentes actores sociales y sus instituciones. Un intento por incidir en los centros de decisión del poder que afectan a la cultura (quizás un repliegue hacia la cultura), en parte debido al fracaso de los ideales revolucionarios. 


\section{LA ÉPICA DE LOS ORÍGENES. \\ EL CICLO DE NOVELAS HISTÓRICAS DE EDUARDO ACEVEDO DÍAZ}

\section{La Novela histórica}

El ciclo de novelas históricas de Eduardo Acevedo Díaz presenta un claro ejemplo de las dimensiones fundacionales que la literatura hizo suyas durante el siglo XIX en América Latina. Escrito en momentos de crisis en la viabilidad del Uruguay como nación, a la que se sumó la dictadura de Latorre, su autor se vuelve hacia las luchas de la Independencia para forjar allí los cimientos del edificio nacional. Su "epopeya científica", como define a sus novelas históricas, traduce -mediada por el positivismo- la épica del origen, que las ficcionalizaciones de la posdictadura reescriben a contrapelo, renegando de las dimensiones fundacionales inscriptas en su tradición para desarmar los andamios que sostenían la entera fábrica del Estado/Nación, sacudida por la experiencia de la última dictadura.

\subsection{La epopeya cientifica}

Acevedo Díaz reflexiona en "Ideales de la poesía americana" (1884) sobre el lugar de la poesía en las sociedades "americanas", y anticipa su propia concepción sobre la novela histórica. ${ }^{15}$

En su visión de "América", Acevedo Díaz participa de la conocida convicción de que el Nuevo Mundo es el espacio donde puede realizarse

15 Eduardo Acevedo Díaz, "Ideales de la poesía americana", en: Crónicas, discursos y conferencias. Páginas olvidadas, Montevideo, 1935, pp. 56-70. 
la utopía iluminista y positivista. ${ }^{16}$ Transforma al "desierto" en el vasto escenario donde confluyen los ideales -"el espíritu de libertad", "la justicia", "la igualdad"- con los avances de la modernización -"el veloz vehículo de acero", "el canal", "el puente", "el hilo telegráfico", "las espléndidas ciudades". América no sólo ha sido convocada al "banquete de la vida", puede además "fundir" los ideales "en sus formas más correctas y en sus sanciones más soberanas" y promete un reino de "perfectibilidad indefinida" (56-60). La independencia renovó los discursos utópicos iniciados con la conquista y los reorientó para programar ahora una utopía "propia", asumida como posible proyecto de las jóvenes repúblicas, con cierta dosis de realismo y lejos de las ciudades fantásticas.

En este Mundo Nuevo que desplaza al futuro próximo toda una tarea de regeneración, el arte -y en especial la "poesía"- se convierte en herramienta necesaria para indicar la vía del progreso. Deberá señalar el camino "universal" del progreso humano, pero al mismo tiempo asumir los rasgos peculiares de América -"amoldarse al carácter y tendencias de la sociabilidad en que se desarrolla". A estas perspectivas heredadas de las primeras generaciones románticas del Río de la Plata, a la figura del poeta civil, Acevedo Díaz suma el perfil del educador científico, de matriz positivista.

En este enlace atribuye a la poesía la capacidad de formular los ideales de las jóvenes repúblicas, mientras la ciencia los orienta en el

16 En esta línea son numerosos los análisis sobre la representación de América Latina como el espacio donde la utopía del Viejo Mundo aún es posible. Cfr. Antonello Gerbi, La Naturaleza de las Indias Nuevas, México, Fondo de Cultura Económica, 1978; O'Gorman, Edmundo, La invención de América, México, FCE, 1977; Leopoldo Zea, América en la historia, Madrid, Revista de Occidente, 1970; Alfonso Reyes, Última Tule, México, FCE, 1960; Fernando Ainsa, De la Edad de oro a El Dorado. Génesis del discurso utópico americano, México, FCE, 1992; Pedro Henríquez Ureña, "La utopía de América", en: La utopía de América, Caracas, Ayacucho, 1978; Bernardo Subercaseaux, Cultura y sociedad liberal en el siglo XIX, Santiago de Chile, 1981, entre otros. 
cauce abierto por el "progreso", liberándolos de fantasías inútiles. La poesía despierta "un fresco rocío de ideales", pero este costado utópico debe superar "la quimera o al delirio" con los aportes de la ciencia -vinculación cercana a las propuestas de los saintsimonianos- para "peregrinar hacia el mayor progreso posible".

Este programa requiere en América una tarea fundadora de los "sentimientos de la patria": "Levantar con sus cantos instituciones elevadas que decaen, retemplar las conciencias que desmayan, dar una nota más alta a las virtudes, encelar los sentimientos de gloria, mantener perpetua la trova al honor, añadir nuevas ofrendas a la patria, tejer coronas de mártir, al héroe, al apóstol (...) y fortalecer en el seno de la familia el culto del amor no conocido por las sociedades antiguas- todo esto pertenece al reino de la poesía americana". Acevedo Díaz coloca en el camino al progreso una mirada hacia las tradiciones de la patria y propone a la "epopeya científica" como el género adecuado para esta síntesis entre el romanticismo heredado y el positivismo reciente. Este texto, ganador en un certamen del "Centro Gallego" de Buenos Aires en 1884 , se anticipa en cuatro años a la publicación de su primera novela del ciclo histórico y la anuncia.

Unas décadas más tarde, en "Sin pasión y sin divisa" (1914), prólogo a su última novela Lanza y sable, los términos de su reflexión cambian, ahora habla directamente sobre la "novela histórica", no sin cierta ironía hacia su par:

"A nuestro juicio se entiende mejor la "historia" en la novela, que en la "novela" de la historia. Por lo menos abre más campo a la observación atenta a la investigación psicológica, al libre examen de los hombres descollantes y a la filosofía de los hechos" (3). ${ }^{17}$

17 Las citas corresponden a Lanza y sable, Montevideo, Biblioteca Artigas, 1965. Abrevio esta novela con las siguientes siglas: LS. 
Estas líneas resumen los debates del siglo XIX en torno a los modos de escribir la historia y sus significaciones. Entre los más importantes, la polémica entre Andrés Bello y Jacinto Chacón (1848) pone en escena dos enfoques de la historia: el primero abogaba por un "método documental" fundado en la observación atenta de los hechos a fin de transmitir su singularidad, posible sólo a través de una narración detallada de los mismos; en cambio el "método interpretativo" (defendido por Chacón) bajo la perspectiva abierta por la filosofia de la historia -heredada de la Ilustración- anteponía a los hechos un sistema articulado por una línea del progreso universal y otros grandes conceptos abstractos. ${ }^{18}$

Entre otras cuestiones, se trataba para Andrés Bello de escribir la historia de Chile aún no redactada y para esta empresa debía comenzarse por un relato de sus "singularidades" que perfilase un pensamiento original que, sin desconocer los avances europeos en la materia, los resignificase en atención a una inédita realidad. Por otro lado, la preeminencia de la filosofía de la historia implicaba un voluntarismo optimista fundado en la convicción de que la teoría podía provocar cambios políticos. La atención a los hechos de la historia de América Latina ponía al descubierto el atraso y el tradicionalismo de las sociedades criollas. Bello no niega la filosofía de la historia, le antepone el estudio minucioso de sus avatares para que aquella se convierta en una filosofía original, capaz de explicar las peculiaridades de Chile ("Sólo por los hechos de un pueblo, individualizados, vivos, completos, podemos llegar a la filosofía de la historia de ese pueblo").

18 Para esta polémica Cfr. "Prólogo" de Mariano Picón Salas en: Temas de Historia y geografia, Tomo XIX, Caracas, Venezuela, 1957; Andrés Bello, "Modo de escribir la Historia", "Modo de estudiar la Historia" y "Constituciones", en op. cit.; y Bernardo Subercaseaux, Cultura y sociedad liberal en el siglo XIX, Santiago de Chile, 1981. 
Interviene aquí también el concepto de larga data de la historia como magistra vitae: "Es necesario hacer el relato de los lustros sombríos, sin calculadas reservas, para que al fin nazcan -dice Acevedo Díaz- ante sus ejemplos aleccionadores los anhelos firmes a la vida de tolerancia, de paz, de justicia y de grandeza nacional" (LS, 4). ${ }^{19}$

La novela histórica se inscribe como género con derechos propios en la capacidad educadora de la historia, convirtiéndose en una textualidad funcional al Estado-Nación ( $\mathrm{y}$ no necesariamente a sus gobiernos). En términos bastantes similares a los de Bello sólo que pasados por el tamiz del positivismo, Acevedo Díaz combina ambas perspectivas para esta finalidad. Le interesa el "método documental" para acceder a la comprensión de los hechos individuales de la historia uruguaya a través de la narración. Desde otro ángulo, la "filosofía de la historia" le permite colocar esos hechos en la línea del progreso por la que Uruguay debe transitar, incluida la utopía del futuro. ${ }^{20}$ Esta "doble visión" -que en Ismael se atribuye a Fray Benito- hacia el pasado y hacia el futuro articula un perfil francamente optimista con otro igualmente pesimista. Me refiero a los términos en que propone su ciclo de novelas históricas. Más adelante revisaré de qué modo selecciona, omite y reinterpreta los "hechos" según su propio proyecto fundacional.

19 Cfr. Koselleck, Reinhart, Futuro pasado. Para una semántica de los tiempos históricos, Bs. As., Paidós, 1993, pp. 41-66.

20 Acevedo Díaz participa de la necesidad que reclama Bello por escribir la historia americana atendiendo a los documentos, de allí que se burle de la "novela de la historia". En "La civilización americana" Acevedo Díaz se ocupó de comenzar esta tarea y allí, en primer lugar, cuestiona la falta de una aproximación científica a los hechos de la historia americana por un lado, y por el otro propone para la historia la misión de "señalar con certero juicio la hermosa senda de paz y libertad a las generaciones del porvenir" (p.120), en "La civilización americana", Crónicas, discursos y conferencias. Páginas olvidadas, op. cit. pp. 118-164. Desde este intento de abordaje de la historia según las demandas de la disciplina científica, Acevedo Díaz da un vuelco hacia la ficción -con el ciclo de sus novelas históricas. En este nuevo espacio es donde negociará las demandas de cientificidad con los requisitos ficcionales. 
Sería bueno recordar, por otro lado, que ya Hegel había sentenciado la suerte de América Latina al colocarla fuera de la historia. Desde el historicismo -y Hegel fue uno de sus padres-, Acevedo Díaz recoloca el destino de estos países en el espacio "universal" (occidental) del progreso de la historia.

La articulación entre pasado y futuro, entre poesía y ciencia, entre tradición y progreso, entre ideales y realidad, entre épica y modernidad, tiene vastas raíces y consecuencias en el ciclo de sus novelas históricas. La figura que enlaza un caballo blanco a otro negro tomada por Acevedo Díaz del Fedro de Platón sintetiza estos vínculos.

\subsection{Espiritualismo y positivismo}

En "Juan Jacobo" y "Diderot" (1900) Eduardo Acevedo Díaz metaforiza, en las dos imágenes del caballo blanco y el caballo negro recién mencionadas, las principales corrientes del pensamiento uruguayo en la segunda mitad del siglo XIX, que van a constituirse -espiritualismo y positivismo- en dos matrices productoras del ciclo de sus novelas históricas. $^{21}$

El espiritualismo ecléctico de Cousin ingresó al Uruguay con la fundación de la Universidad en 1849, convirtiéndose en la doctrina hegemónica durante el período de la anarquía social y política, caracterizado por el conflicto entre caudillismo y civilismo. Tal como la define Arturo Ardao, la filosofía espiritualista cumplió la misión histórica de "cohesión moral e intelectual" de la minoría ilustrada. ${ }^{22} \mathrm{Y}$ es este espiritualismo el que sostiene diversas vertientes culturales: "Miradas

21 Eduardo Acevedo Díaz, "Juan Jacobo" y "Diderot", en: Crónicas, discursos y conferencias. Páginas olvidadas, Montevideo, 1935, pp. 71-95

22 Arturo Ardao, Espiritualismo y positivismo en el Uruguay, Montevideo, [1950] 1968. 
desde el ángulo de la filosofía adquieren unidad las manifestaciones salientes de la cultura en ese período: el romanticismo en literatura, el principismo en política, el deismo racionalista en religión, el laicismo en el orden educacional. Todas ellas se hallan de algún modo vinculadas a la doctrina espiritualista" (50) En este haz de significaciones del espiritualismo, me interesa la adscripción de Acevedo Díaz al principismo político y al romanticismo social y literario como perspectivas desde las cuales lee y configura el proceso de las guerras de independencia en sus novelas históricas.

El principismo uruguayo se caracterizó por pregonar los "principios de libertades públicas y derechos individuales con los ojos puestos en una república ideal, la república del derecho natural y de la razón pura" (51), que procuraron hacer efectivos -sin éxito- en el gobierno "típicamente universitario y doctoral" de José Ellauri, derribado en 1875 por el golpe militar de Latorre. Frente a esta dictadura, el principismo se reorienta como perspectiva crítica ante la suspensión de los derechos constitucionales.

El positivismo, que llegó al Uruguay en la década de 1870 y se asentó durante la dictadura de Latorre (1875), implicó una renovación en varios niveles: los estudios universitarios ingresaron al cauce abierto por el positivismo y se inauguraron bajo su influjo diversos campos de investigación. El positivismo vino a desarrollar una nueva teoría política como herramienta para comprender el pasado y el presente del Uruguay $\mathrm{y}$, en este sentido, resultó funcional al proyecto de Latorre aun cuando no todos los positivistas dieron apoyo a su gobierno. Finalmente, otorgó a Latorre un marco adecuado para encaminar el proceso modernizador.

El positivismo significó una crítica al principismo por su divorcio de la realidad social y su anteposición de los principios del liberalismo constitucionalista y la moral cívica a los factores reales de la historia de 
un Uruguay que no había logrado salir de las revueltas y luchas entre fracciones. Condujo a la política desde "el academicismo de los principios constitucionales al realismo económico y social" (254) proporcionando a "las clases dirigentes el sentido sociológico que les faltó a las generaciones principistas" (261). Ante el proceso modernizador que se desarrolló en las últimas décadas del siglo XIX, el positivismo "significó la incorporación de un instrumento ideológico para la comprensión y encauzamiento de esa misma transformación" (262) y "fue deliberadamente acogido como instrumento de acción sobre la realidad nacional para modificarla y superarla" ( 254$)$.

Eduardo Acevedo Díaz articula ambas matrices en su proyecto literario y político. En su prosa combina características del romanticismo y del realismo-naturalismo, y utiliza alternativamente narradores que representan cada una de estas tendencias. En su proyecto político apunta al desarrollo de la modernidad uruguaya retomando, sin embargo, la tradición anclada en el pasado de las luchas independentistas; utiliza además, para describir las fuerzas históricas, perspectivas románticas (como la revolución) y positivistas (como la evolución lenta y gradual). De este modo, la propuesta final de Acevedo Díaz retoma el valor y la vigencia del romanticismo y del positivismo en una imagen del encuentro de ambas: "No es posible hablar de los dos sin traer al recuerdo aquella imagen que el filósofo griego presentaba bajo la forma de un tronco de corceles; blanco el uno, negro el otro, unidos por lazo indisoluble y flotando en los aires: símbolo el primero de anhelos inexplicables e ideales vigorosos, y emblema el segundo de la realidad amarga y del dolor positivo" (84). 


\section{Un proyecto nacional}

Su programa de un ciclo de novelas históricas, de una epopeya científica se vierte en un proyecto nacional donde coloca las fuerzas históricas, las determinaciones del medio, las peculiaridades del pueblo oriental para diseñar el futuro del estado/nación. Entonces, podemos preguntarnos ¿Cómo se representa la nación uruguaya en las novelas históricas de Eduardo Acevedo Díaz?

Para ello voy a partir de una de las reflexiones que en torno a la novela histórica formula Noé Jitrik en su libro Historia e imaginación literaria. ${ }^{23}$ Allí describe el contexto de enunciación de la novela histórica en América Latina durante el siglo XIX teniendo en cuenta la idea de crisis o ruptura -en especial la que provoca la independencia- que socava una determinada estructura social y provoca un cuestionamiento en la identidad comunitaria. Frente a este trastorno "la novela histórica intenta, mediante respuestas que busca en el pasado, esclarecer el enigma del presente".

Otra de las consecuencias de la independencia sería la siguiente: "no sólo se deja de ser español para ser "criollo" con todas sus variantes sino que muy pronto hay venezolanos, colombianos mexicanos, cubanos, argentinos, chilenos, peruanos, bolivianos, uruguayos y demás, casi de la noche a la mañana, y tales designaciones, que tienen seguramente un sentido político muy preciso, son como formas vacías o como ambiguos proyectos". Esta cita, en mi opinión, describe la lógica entre las implantaciones políticas de los estados en América Latina logradas con la independencia y la subsiguiente necesidad de construir naciones,

23 Jitrik, Noé, Historia e imaginación literaria. Las posibilidades de un género, Bs.As, Biblos, 1995. 
entendidas éstas como comunidades imaginadas capaces de dar una identidad a sus pobladores. ${ }^{24}$

Esta ecuación Estado/Nación alcanzó un grado extremo en Uruguay ya que, como veremos, su independencia definitiva de la Argentina y de Brasil sobrevino abruptamente impulsada, en gran medida, por las negociaciones diplomáticas de Gran Bretaña y no fue el resultado de un proyecto definido de la política oriental.

Si revisamos la historia uruguaya, en pocos casos parece más acertada esta afirmación de que el estado precedió a la nación. En la formación del estado uruguayo es lícito tender un arco desde la independencia oriental alcanzada definitivamente con la jura de la Constitución en 1830 hasta el último tercio del siglo XIX, en el cual se intenta, a través de diversos ensayos políticos, consolidar un estado centralizado que permita la práctica de las instituciones democráticas -en especial el sufragio, la estabilización de los partidos políticos, la libertad de prensa- y que articule el proceso modernizador impuesto por los países industriales.

Este proyecto alcanzó a realizarse con los gobiernos de Batlle y Ordóñez a comienzos del siglo XX. En este recorrido, el último cuarto del siglo XIX aparece como un momento en que la crisis, inaugurada con la independencia y presente en las décadas subsiguientes, se ahonda y se convierte en un problema que debe resolverse.

24 Varios son los trabajos que sostienen, con variantes, el carácter imaginario y simbólico de la nación ("comunidades imaginadas", "artefacto", "invención", "narración de la nación") y la "paradoja" de la posterioridad de la nación que sin embargo coloca su "origen" en tiempos anteriores. Cfr. Gellner, Ernest, Naciones y nacionalismo, op. cit.; Anderson, Benedict, Comunidades imaginadas. Reflexiones sobre el origen y la difusión del nacionalismo, op. cit.; Hobsbauwm, E. J., Naciones y nacionalismo desde 1780, op. cit.; Nora, Pierre, Les Lieux de Mémoire, op. cit.; Bhabha, Homi, "Introduction: narrating the nation", en: Nation and Narration, op. cit. 
Los inicios de la vida independiente del Uruguay se vieron sacudidos por los constantes enfrentamientos entre las divisas, situación que perduró hasta las últimas décadas a través de los conflictos entre blancos y colorados, entre "caudillos" y "doctores" que aún provocarán levantamientos armados. La debilidad de las instituciones para organizar el país, el fraude electoral, la constante intervención de argentinos y brasileños, la incapacidad para centralizar el poder obstaculizaban la unidad nacional. Los gobiernos ensayaron infructuosamente diversas soluciones, desde el caudillismo de Venancio Flores hasta el gobierno principista del Dr. Ellauri para culminar con la dictadura de Latorre.

La modernización requería prontas medidas tendientes a crear el orden interno necesario para convertir al Uruguay en productor y exportador de materias primas y consumidor de manufacturas, con ello se hace urgente la necesidad de pacificar el país y consolidar las instituciones. Este clima de crisis e inestabilidad coloca en el centro de los debates a la nación y su futuro.

Este momento en que se intenta construir un estado fuerte y centralizado que a la vez responda al modelo republicano democrático así como al proyecto modernizador, dispara una serie de bosquejos en torno a la nación. La literatura, y en el caso que nos ocupa la novela histórica, se ofrece como espacio capaz de debatir el futuro del Uruguay; prueba de ello fueron las múltiples obras que se ocuparon del tema, como por ejemplo las de Zorrilla de San Martín, Carlos Reyles, José E. Rodó, entre otros. Eduardo Acevedo Díaz formula sus propias respuestas a la crisis a través de una relectura del pasado en la que traza sus propuestas para el futuro.

Los tropiezos de las primeras décadas, la debilidad de las instituciones, la incapacidad de mantener la paz y la consiguiente crisis de viabilidad y también de identidad ante la cercanía de Argentina y 
Brasil, se constituyen en el trasfondo que impulsa a Eduardo Acevedo Díaz a una representación del Estado-Nación como una entidad sustentable, fuerte e independiente. Así la novela histórica se convierte en un espacio fundacional de la identidad oriental: allí la nación como identidad comunitaria y el modelo de estado van a ser sus dos preocupaciones principales. ${ }^{25}$

Sus novelas históricas abarcan el período 1808-1838, es decir los momentos previos a la independencia, los primeros levantamientos independentistas de la campaña en 1811 y la victoria artiguista en Las Piedras (Ismael); la dominación portuguesa y brasilera que convirtió a la Banda Oriental en Estado Cisplatino (Nativa); el desembarco de los Treinta y Tres Orientales y sus victorias de Rincón y Sarandí contra las tropas brasileras (Grito de gloria), y las guerras civiles entre Rivera y Oribe durante la presidencia de éste último (Lanza y sable).

Estos momentos claves en los inicios nacionales son recuperados por Eduardo Acevedo Díaz a partir del contexto de los años de escritura y publicación de sus novelas -de 1888 a 1914. Resulta indispensable, por lo tanto, poner en correlación sus textos con las discusiones sobre el presente y futuro de la nación, así como con la realidad del momento en la cual Acevedo Díaz tuvo una actuación política destacada. He seleccionado para ilustrar este tema los debates presentes en sus novelas históricas, en especial los problemas en torno a la viabilidad del Uruguay como país independiente, las disputas entre el modelo de país propuesto

25 Es Doris Sommer quien ha insistido en la categoría de "foundational fictions" para analizar los "romances" o novelas de amor, en su obra Fundational Fictions. The National Romances of Latin America, University of California Press, 1991. Aquí, sin embargo, me gustaría pensar el problema a partir del género novela histórica más que de los "romances", por lo que prefiero la categoría de "discurso fundacional" -más cercana a otros discursos no necesariamente ficcionales- tal como la utiliza Florencia Garramuño en Genealogias culturales. Argentina, Brasil y Uruguay en la novela contemporánea (1981-1991), Rosario, Beatriz Viterbo Editora, 1997. 
por blancos y colorados, y el impacto de la modernización nacional en las últimas décadas del siglo XIX.

Voy a comenzar distinguiendo tres tipos de discursos que proyectan cada uno un aspecto diverso del modelo de nación y estado propuesto por Eduardo Acevedo Díaz en sus novelas.

La tesis de la independencia clásica coloca los orígenes de la nación uruguaya en la lucha por la independencia, considerada como un anhelo constante y un logro del pueblo oriental. Procura responder a los cuestionamientos sobre la "viabilidad" del Uruguay como país pequeño frente a sus vecinos argentinos y brasileños, afirmando la existencia de una nación previa al estado.

Los ideales republicanos, las instituciones de las democracias y los valores del iluminismo conforman una utopía democrática en los inicios de Ismael, que se convertirán en Lanza y sable en el proyecto político fundado en un discurso civilista.

La representación de la naturaleza oriental como un discurso de la abundancia propone el modelo de un país agrícola ganadero, cuya riqueza comienza como un don de la naturaleza que debe explotarse mediante los medios aportados por la modernización. ${ }^{26}$

A través de la representación de las primeras décadas de la historia uruguaya, Acevedo Díaz procura responder a estos debates sobre el destino nacional que fueron definitorios en el período en que escribió sus obras.

26 Tomo la idea del "discurso de la abundancia" de Julio Ortega, El discurso de la abundancia, Caracas, Monte Avila, 1992. 


\section{La narración de la nación y sus emblemas}

Voy a tener en cuenta en mi análisis dos operaciones a través de las cuales la nación se ficcionaliza, ingresa a la textualidad peculiar del género. Por un lado se trata de una narración de la nación focalizada fundamentalmente en el "origen" nacional aunque se extiende unas décadas más para incluir el futuro como utopía. ${ }^{27}$ Esta narrativa selecciona aquellos eventos que ingresan a las novelas y luego los distribuye en el espacio del texto (comienzo, medio y final) para diseñar la trama (el "plot" en términos de Hayden White). Esta estrategia implica además la elección de un estilo acorde a cada evento: las batallas y triunfos se narran desde los aportes de la épica, mientras los finales de cada novela irrumpen con una nota trágica; las escenas amorosas -para detenerme en un solo ejemplo- delatan desde una prosa romántica hasta otra naturalista según el objeto representado. Las novelas, además, exhiben el encuentro de una lengua literaria y de un registro científico que procura explicar, a veces en extensas digresiones, las causas y factores que mueven las fuerzas históricas.

Por otro lado, la nación se articula en torno a una serie de imágenes que adquieren el valor de emblemas, figuras, símbolos que, en una operación de índole metonímica, suelen sintetizar aquellos eventos o momentos representativos de la memoria nacional. En esta línea, los personajes como "tipos" representativos -en el sentido utilizado por Lukács- de las fuerzas históricas en pugna; los espacios (pago, patria, desierto, Montevideo, etc.); las relaciones intersubjetivas en términos de alianzas, triángulos amorosos, dependencias laborales, lazos familiares; los viajes y experiencias de aprendizaje, configuran el campo simbólico

27 Cfr. Homi Bhabha, especialmente, "Introduction: narrating the nation" donde enfatiza la proyección que la nación hace de sí misma a un origen que se pierde en un "pasado inmemorial" y hacia "un futuro ilimitado", op. cit. 
de la nación. Ambos ángulos se trabajarán intercalando en el relato de la nación el análisis de sus símbolos.

\subsection{La tesis de la independencia clásica}

La dictadura de Latorre no sólo pone en crisis las instituciones democráticas; de un modo más profundo cuestiona la viabilidad del Uruguay como país independiente.

Para Arturo Ardao la independencia definitiva del Uruguay ha constituido, durante el siglo XIX, un "problema" a la vez "histórico" y "político", acentuado por las continuas intervenciones de Argentina y Brasil. $^{28}$ Fue durante la década de 1870 que el sentimiento de nacionalidad sufre un profundo cuestionamiento, especialmente en los debates suscitados a partir de la erección del monumento a la Independencia en 1879, en la villa de Florida. Una rápida revisión de las diversas opiniones que este acto convocó dará cuenta del clima del momento. Como antecedente, José Pedro Varela en su obra La legislación escolar (1876) se refiere a la "independencia amenazada" por las aspiraciones de ambos vecinos permitidas, por las disidencias internas y la anarquía predominante que ha ido "debilitándonos, empobreciéndonos, aniquilándonos cada vez más y en consecuencia, haciendo cada vez menos viable nuestra nacionalidad". ${ }^{29}$

La inauguración del monumento a la Independencia hizo público el debate y enfrentó divergentes posturas. Juan Carlos Gómez expresó profundas reservas sobre la factibilidad de las nacionalidades pequeñas encontrando en la reconstrucción de la "vieja unidad platense" una

28 Ardao, Arturo, "La independencia uruguaya como problema", en: Etapas de la inteligencia uruguaya, Montevideo, Universidad de la República, 1971.

29 Citado por Ardao, op. cit. p. 188. 
posible solución al problema de la estabilidad institucional. Refutando las tesis de Gómez, José Pedro Ramírez, si bien reconoce las dificultades, apuesta al mantenimiento de la independencia ya que "la independencia de este país es un hecho producido por su voluntad consciente, afirmado por un tratado que es en sí mismo una solución de paz entre los países limítrofes y confirmado por medio siglo de vida nacional; este país se ha dado instituciones que no funcionan o funcionan mal; el problema está circunscripto a restaurar el imperio de esas instituciones, a popularizarlas e imponerlas como una necesidad suprema, como el único medio de radicar la paz, de conservar la nacionalidad, de hacer libres, felices y dignos a los ciudadanos que se agrupan bajo su bandera". ${ }^{30}$

La tercera y última postura se encuentra en el libro Nirvana de Angel Floro Costa (1880) quien percibe como destino más probable para el Uruguay, su reincorporación al Brasil como Provincia Cisplatina.

De este modo el problema "político" de la independencia implica la viabilidad del Uruguay como un país soberano, capaz de fortalecer sus instituciones democráticas en un clima de paz.

El problema "histórico" discute la adecuada fecha de la independencia y pone en juego diferentes lecturas sobre la historia uruguaya de las primeras tres décadas del siglo XIX. La crisis del sentimiento de nacionalidad durante la década del setenta provoca como reacción la necesidad de fortalecerla, y ello se verifica en una peculiar interpretación que hace de la independencia absoluta del Uruguay un logro largamente anhelado y finalmente alcanzado por la casi exclusiva voluntad y acción de los orientales. Real de Azúa denomina "tesis de la independencia clásica" a esta versión de la historia uruguaya. ${ }^{31}$

30 Citado por Ardao, op. cit. p. 197.

31 Carlos Real de Azúa, Los orígenes de la nacionalidad uruguaya, Montevideo, 1991. 
Veamos el debate. Si la empresa de los Treinta y Tres Orientales, que desembarcó en 1825 en las costas uruguayas, se proponía liberar al entonces llamado "Estado Cisplatino" del dominio luso-brasilero, declaró en la Asamblea de la Florida (25 de agosto de 1825) no sólo la independencia de la Banda Oriental sino además su "unión" con las Provincias del Río de La Plata. Recién en 1828, la Convención Preliminar de Paz reunió a representantes de la Argentina y Brasil, previa mediación de Gran Bretaña, en Río de Janeiro para declarar la independencia absoluta de la Banda Oriental del Uruguay. Pero allí no figuraron representantes de esta última. La Constitución nacional fue jurada el 18 de julio de 1830 .

Entre estos dos hechos ha quedado oscilando el debate sobre la fecha de la independencia como un momento problemático, si no traumático. El debate pone en juego varias cuestiones entre las que no están ausentes los tintes partidarios de blancos y colorados.

Si se toma como fecha la Convención Preliminar de la Paz o algunas de sus consecuencias, como la entrada en vigencia de la Constitución, la independencia quedaría forjada, fundamentalmente, por un pacto realizado entre potencias extranjeras, Brasil y Argentina, que no convocaron a los propios interesados para su firma. Asimismo esta Convención fue el punto culminante de la mediación que Inglaterra y sus intereses comerciales llevó a cabo eficazmente a través de Lord Ponsonby, una mediación interesada en crear un "Estado tapón" para evitar que las márgenes del Río de La Plata quedaran en una sola mano, la argentina, o en dos manos poderosas, la argentina y la brasilera.

En cambio cuando se elige la empresa de los Treinta y Tres Orientales como inicio de la independencia nacional, los actores principales, más allá de si hubo o no un apoyo argentino, pueden presentar sus credenciales orientales. El problema aquí se centra en las 
declaraciones de la Asamblea reunida en la Florida al poco tiempo, ya que luego de la declaración de la independencia se decretó la "unión" con las Provincias del Río de La Plata.

Si los orígenes de la nacionalidad uruguaya se mueven entre estos dos eventos históricos que no alcanzan a satisfacer el orgullo nacionalista, en cambio la historiografía oficial ha elaborado un relato de la independencia capaz de presentarla como un triunfo del pueblo oriental largamente deseado. Eduardo Acevedo Díaz se inscribe en esta empresa que intenta pautar la independencia como un destino inevitable de los orientales, desarrollando en sus novelas históricas las siguientes tesis:

1- Bajo los presupuestos del positivismo, la idea del Uruguay como nación independiente se naturaliza en base a los determinismo del medio (el territorio y sus límites "naturales", el clima y la naturaleza), la raza y el momento. La peculiaridad de cada uno de estos factores debía desembocar necesariamente en el surgimiento de un estado independiente..$^{32}$ Con ello la nación se reviste de un carácter ahistórico y adquiere la fuerza de lo inevitable. La nacionalidad podrá desviarse, oscurecerse, tergiversarse por ciertas fuerzas contrarias de la historia o por los intereses de la política, pero no por ello va a desaparecer.

Dice el narrador en Nativa: "...la transformación étnica -fenómeno natural- creaba nacionalidades independientes de las fórmulas políticas, en armonía con las condiciones de cada región y clima, con las diversas influencias de razas y con las costumbres locales. Así iban surgiendo en

32 Los criterios para definir la nacionalidad que utiliza Acevedo Díaz se corresponden con aquellos que los historiadores anteriormente citados (Gellner, Andreson, Hobsbauim, etc.) reconocen para las naciones occidentales en la etapa del liberalismo burgués (1830-1880): la lengua (que en el caso de estas novelas se vehiculiza en el uso de regionalismos, ya que, a diferencia de las naciones europeas, la lengua era compartida no sólo por la gran mayoría de las naciones latinoamericanas, sino también por España), el territorio, la etnicidad, la religión (en menor medida en el caso de Acevedo Díaz dada su participación en las corrientes anticlericales de las últimas décadas del siglo XIX), tradición y costumbres. 
vastísimas comarcas (...) una acción unitaria, argentinos, orientales, paraguayos y bolivianos (...) Dada pues, la naturaleza del terreno respectivamente, y la calidad de la semilla, el desarrollo y crecimiento de ésta dependía de circunstancias. Podía malograrse la obra, como hubo de suceder desde sus comienzos; pero la garantía del éxito estaba en la energía de la raza". ${ }^{33}$

Estas ideas se traducen fundamentalmente en dos cuestiones: por un lado la importancia que la naturaleza oriental ocupa en el ciclo de las novelas, y sus variadas y extensas descripciones. Por el otro, la naturaleza como principio rector determina y condiciona a la historia: la historia sigue la evolución natural o, de lo contrario, se "desvía". ${ }^{34}$

2- Según los hechos históricos, la independencia absoluta fue el resultado de una serie compleja de factores, entre los que ejercieron fuerte presión los intereses británicos, argentinos y brasileños. Frente a ello la tesis independentista clásica insiste en el carácter netamente oriental de su independencia y procura ver, en variados hechos del pasado, señas de una voluntad autonómica. Para colocar a la independencia como triunfo exclusivamente oriental, Acevedo Díaz despliega estrategias que le permiten sortear los datos históricos. Veamos algunas de ellas:

* En principio antedata la voluntad autonómica de los orientales verificando en el período colonial su emergencia. Esta idea influye en la

33 Nativa, Montevideo, Biblioteca Artigas, 1964, pp.390-391.

34 En Nativa se utiliza la fórmula del desvío. La Banda Oriental como Estado Cisplatino se encuentra bajo la dominación luso-brasilera, momento más débil de la nacionalidad oriental. En este contexto, el espíritu independentista aparece "desviado" de su cauce natural ya que ha sustituido "con otras costumbres y otro idioma el lenguaje y los usos consagrados por los siglos; sin advertir que la historia, la naturaleza, el clima, los instintos peculiares de raza y de índole etnológica (...) hacían inconciliables esos propósitos con el instinto local" (N: 131). 
estructura de Ismael y determina la elección de los eventos históricos que ingresarán al texto. Selecciona como comienzo no la rebelión de la campaña de 1811 sino el conflicto del gobernador Elío con el virrey Liniers, un acto de resistencia ante las políticas porteñas que prefigura la vocación independentista de su pueblo y anticipa el levantamiento de la campaña. ${ }^{35}$ Este desacato se convierte en el momento clave de la separación de la Banda Oriental del resto del virreinato: "la unidad nacional perdió un eslabón, que no pudo luego reatar el esfuerzo libre", dice en Ismael el narrador. ${ }^{36}$ Entonces Acevedo Díaz lee en los momentos previos a la independencia un evento que traduce el designio de independencia absoluta.

* En la campaña y sus gauchos Eduardo Acevedo Díaz coloca la tesis de la independencia como una "necesidad", articulada por los presupuestos positivistas que hacen del medio y el momento, los gauchos y sus costumbres, los factores desencadenantes del impulso revolucionario. La "sociabilidad primitiva" de los tupamaros, cuyo principal valor consiste en el "amor al pago" junto con la incapacidad para aceptar cualquier tipo de sujeción externa ("los que vivían sin rey ni ley"), resulta una forma embrionaria del instinto de independencia y de la idea de patria. ${ }^{37}$ En la trama de sus novelas la descripción del medio y las costumbres del gaucho ocupan extensas páginas, en las cuales, sin

35 La rebelión del gobernador Elío tuvo una intención deliberada a favor de la corona, fue contrarrevolucionaria y respondió a una politica de obediencia hacia el rey español ya que Liniers estaba sospechado de bonapartismo. La interpretación que lleva a cabo Fray Benito invierte el significado de dicho acto político y lo convierte en precursor de la independencia frente a la Argentina ya que implica un desacato frente a Buenos Aires.

36 Ismael, Bs. As., Ed. Jackson, 1946, p.13.

37 Dice el narrador en Ismael: "La vida de aislamiento formó en las muchedumbres de los campos el 'carácter local', el círculo estrecho de la patria al alcance de la mirada, el egoísmo fiero del pago y del distrito, germen de la descentralización futura, y, a su vez, arranque originario de una vida independiente y soberana en la oscura fuente de las soberbias cerriles" (I: 52 ). 
solución de continuidad, Acevedo Díaz pasa, en la caracterización de la vida de la campaña, del "carácter local" a la descentralización futura, a la "vida independiente y soberana" que comenzaba a perfilar "el espíritu de nacionalidad que nacía débil y vacilante".

* Otra de sus estrategias consiste en atribuir a los orientales, en especial a los gauchos y caudillos, una idea de independencia absoluta que permanece en las zonas indefinidas del instinto y del sentimiento, oscilante entre lo primitivo, latente, confuso o inconsciente, que no alcanza a formularse en una idea clara ni en un proyecto político definido -"(...) sin rumbos bien definidos ni aspiraciones subordinadas a un ideal fijo y luminoso" (I: 232)). Estas aserciones permiten sortear cualquier intento de verificación sobre una voluntad del pueblo que se presenta como inconsciente.

* Asimismo desplaza el tema de la independencia de los ámbitos de negociación, de los acuerdos y pactos firmados y de los documentos emanados de los mismos para situarlo en la "voluntad del pueblo". Para ello minimiza y desprestigia las acciones que se resuelven en el campo de la política, contrarias a las "verdaderas" intenciones de los orientales. Grito de Gloria describe la gesta de los Treinta y Tres Orientales sin olvidar la Asamblea de la Florida. Si allí se declaró la anexión, este acto obedeció a la "necesidad" política, mientras sus autores sostienen el deseo de una independencia absoluta y afirman la viabilidad de la futura nación: "Nación independiente podemos ser. Los paisanos no quieren ser más que orientales".

De este modo la anexión se convierte en "máscara" que oculta una intención de independencia absoluta y que se vale de las conveniencias políticas como medios eficaces para llegar al fin deseado: "Lo que nos convendría sería difundir la especie de la reincorporación una vez que 
invadiéramos" 38 . En la perspectiva de Luis María Berón sobre las resoluciones de la Asamblea de la Florida se reitera el rechazo hacia la política como ámbito de negociaciones que no reflejan la voluntad popular: "A esta triste alternativa estaba condenado el ideal de la aventura por la política insensible y la fría diplomacia (...) Contra esta resolución se habían estallado todos los esfuerzos y los ruegos del pueblo oprimido, las vehementes insinuaciones de espíritu nacional, los argumentos de los tribunos y del patriotismo exaltado" (GG: 178).

* Por último establece una continuidad entre proyectos políticos que la historia marca como diferentes. El deseo de independencia frente a la corona española se articuló, en su primera manifestación, a través del proyecto artiguista que hacía de la Banda Oriental una provincia más del ámbito platense. Lavalleja y sus Treinta y Tres Orientales demostraron similares intenciones en la Asamblea de la Florida. La independencia absoluta tal como surgió en la Convención Preliminar de la Paz implicaba un modelo opuesto. Ya anteriormente Artigas había rechazado la propuesta emanada de Buenos Aires a fin de crear un Estado independiente. ${ }^{39}$ Ahora bien, la estrategia de Acevedo Díaz consiste en diluir la oposición entre los proyectos de independencia relativa, propios de Artigas y Lavalleja y la final independencia absoluta del pueblo oriental, para poder tejer una continuidad, un recorrido progresivo del sentimiento de independencia desde sus inicios coloniales hasta su

38 Grito de gloria, Bs. As., 1954, p.15-16.

39 En sus Instrucciones del Año XIII, donde consta su programa político, Artigas propone la defensa de la "soberanía particular de los pueblos" como respuesta a las pretensiones hegemónicas de Bs. As. e integra esta "autonomía" provincial en un Estado de base federal. A mediados del año 1815 el Director Alvarez Thomas le propone reconocer la independencia total de la Banda Oriental del Uruguay. Artigas rechaza la oferta ya que contradecía el "significado provincial, pero no nacional de la independencia oriental, implicando una segregación que el caudillo nunca había propuesto y jamás aceptó", Cfr. Reyes Abadíe, W., Bruschera, O., Melogno, T., El ciclo artiguista, tomo 3, Montevideo, 1968, p. 91. 
resolución final. ${ }^{40}$ En el capítulo inicial de Nativa el narrador señala esta continuidad que se articula entre sus obras: "Esta introducción se hacía necesaria para vincular épocas y eslabonar sucesos, y también para dar una idea clara en sus efectos de las causas impulsivas y móviles determinantes de los actos, esfuerzos y sacrificios de patriotismo de la generación heroica que no creyó concluida su obra generosa hasta después que declaró a la faz del mundo que su tierra era ya independiente de todo poder extranjero, y que se imponía como forma definitiva de gobierno las instituciones libres" (N: 25)

40 La postura de Artigas sobre la independencia es presentada con cierta dosis de ambigüedad y se le atribuyen ideas diferentes cuando no contradictorias. Por un lado se le adjudican al mismo tiempo las dos alternativas de la autonomía relativa y absoluta: "Ya se considere al futuro caudillo animado de un patriotismo puro, ya bajo el influjo de las pasiones que sirvieron más tarde como nervio de resistencia a la emancipación local" $(I, 325)$. En otras referencias se acentúa el deseo de autonomía del proyecto artiguista y aquí es el término "autonomía" el que resulta ambiguo. Si con él Artigas se refería a la Banda Oriental como provincia y no como Estado independiente, en estas novelas la autonomía se convierte en un momento clave de un itinerario inevitable que comienza con el "amor al pago", sigue con la "autonomía" para lograr la "independencia absoluta": "Preciso es reconocer que si no lo sostenían en esa forma, no era porque creyesen que con la desaparición de Artigas del teatro de la lucha había cesado la causa de resistencia en los orientales a reincorporarse a Buenos Aires o a cualquier otro país..." $(N, 23)$.

En Nativa y Grito de gloria comienza a acentuarse la continuidad entre el proyecto de Artigas y el de los Treinta y Tres Orientales: "a la lanza ya rota de Artigas debía suceder lógica y fatalmente el sable de Sarandí" $(N, 241)$. Y la conexión entre ambos se da a través de la coparticipación en el deseo de independencia absoluta que se ve coartado por los intereses dominantes de argentinos y brasileros. De este modo Carlos Berón interpreta la reincorporación de la Banda Oriental al Río de La Plata como la única alternativa posible frente a los intereses de los poderosos vecinos e incluye en esta estrategia no sólo a los Treinta y Tres Orientales, sino al mismo Artigas: "Ahora que usted me diga que sintiéndose débiles entre dos piedras de molino, notando que van a ser machacados se resuelvan a la incorporación a las otras provincias, de acuerdo, si señor; de completo acuerdo. ¿No intentaron lo mismo cuando Artigas, como medio de salvarse?" (GG, p.105). Estas palabras de Berón resultan el punto culminante de las perspectivas sobre el proyecto artiguista ya que sugieren una intención oculta de independencia absoluta que se recubrió con el modelo federado por conveniencias políticas. Como veremos a continuación Grito de gloria propone la misma interpretación para el proyecto de los Treinta y tres orientales. 
Recapitulando, Acevedo Díaz articula una narración de la nación siguiendo las perspectivas de la tesis de la independencia clásica: el destino de independencia absoluta está inscripto en la naturaleza distintiva del Uruguay y se encuentra ya no sólo en el instinto de los gauchos sino en la historia de la colonia continuada por las luchas de Artigas y Lavalleja. Este seguimiento de la tesis de la independencia clásica es el que va a determinar, en gran parte, la estructura de cada novela y del ciclo completo; a partir de ella se seleccionan los eventos históricos que ingresan en el relato. En definitiva lo que intento señalar es de qué modo la narración de la nación que las novelas articulan sigue las pautas de esta tesis.

Para establecer esta continuidad utiliza la idea positivista de evolución que impregna su concepción de la historia. Cada etapa importa una diferente modulación acorde al momento histórico, de una permanente voluntad de autonomía absoluta propia del pueblo oriental. Teniendo en cuenta ese deseo Eduardo Acevedo Díaz elige y encadena los eventos históricos que le permiten diseñar ese recorrido, fundamentalmente el triunfo artiguista y las primeras victorias de los Treinta y Tres Orientales, antes de que los orientales reciban la ayuda argentina. Asimismo minimiza o descarta aquellos momentos que puedan contradecir sus tesis: si la Asamblea de la Florida aparece como una necesidad política, la Convención Preliminar de la Paz ni siquiera es mencionada ni, menos aún, la injerencia de la diplomacia británica.

La resolución que Acevedo Díaz da al "problema histórico" a favor de la tesis de la independencia clásica -su reconstrucción del pasado cifrado en el relato de la independencia como un logro netamente oriental- se convierte en una respuesta al "problema político", reafirmando en el presente la viabilidad del Uruguay como estado soberano cuando, como vimos, era puesta en duda por ciertos sectores intelectuales. 
Acevedo Díaz construye esta imagen sólida del Estado/Nación frente al quiebre que la dictadura de Latorre significó en la historia de su país. En el exilio argentino va a responder a la "tiranía" buscando en el pasado histórico los valores obturados por este gobierno inconstitucional: encuentra en las guerras de independencia los principios de libertad e independencia.

Me interesa ahora analizar, por un lado, las significaciones que la revolución independentista adquiere en el ciclo de sus novelas como fundadora de una tradición revulsiva a la cual es posible volver cuando la vida política la niega. Por otro, la revolución es representada desde la matriz principista y romántica, asociada a la figura de Rousseau. Si, en términos generales, Acevedo Díaz organiza una temporalidad histórica signada por la flecha del tiempo del progreso, considera dos modalidades en que el progreso puede resolverse: la revolución, asociada al romanticismo, actúa como un quiebre en la historia, como un salto en el proceso de desarrollo de las sociedades; mientras la evolución de raíz positivista se cumple en una temporalidad lenta y gradual, sin saltos bruscos, como ya he dicho.

\section{Presente/ Pasado: la historia como tradición revolucionaria}

En los comienzos del año 1875 el orden constitucional es quebrado por el golpe de estado de Latorre. Eduardo Acevedo Díaz, desde las páginas de la Revista Uruguaya, denuncia las consecuencias de la reciente "dictadura": "la honradez y las virtudes cívicas eran acechadas y tenazmente perseguidas; el patriotismo vilipendiado, la justicia desconocida, el derecho y la libertad holladas; el trabajo infecundo; la hacienda estéril; el egoísmo imponiéndose como suprema ley." 41

41 "La última palabra del proscrito", en La Revista Uruguaya, n. 15, Montevideo, 1875 , p.114. 
El derrocamiento del gobierno de Ellauri clausuraba las posibilidades del proyecto principista basado en el restablecimiento del orden administrativo, de las garantías constitucionales, de la tolerancia política y de la libertad de prensa. Un modelo liberal y civilista, poco factible para un país que aún no había logrado superar las luchas internas.

En el último número de la corta existencia de esta revista, clausurada por los virulentos artículos de Acevedo Díaz, éste imagina una escena de alto contenido simbólico. Latorre oye el Himno Nacional frente a sus tropas y las palabras "Libertad, libertad, orientales..." le provocan una alucinación en la cual los soldados se aprestan a sublevarse contra su gobierno. La tradición libertaria de la gesta independentista se recupera en el presente para derrocar al tirano o, incluso, para eliminarlo. "Si enemigos, la lanza de Marte. Si tiranos, de Bruto el puñal!" finaliza el texto ( la cursiva no es mía). ${ }^{42}$

Eduardo Acevedo Díaz construye los valores de la tradición a partir de la idea de libertad plasmada en la independencia y conseguida a través de la guerra. La defensa de esta tradición justifica la revolución armada cada vez que un gobierno dictatorial obtura el libre ejercicio de la democracia. ${ }^{43}$ Esta idea lo llevó a participar en la Revolución de las Lanzas de Timoteo Aparicio (1870) y en el levantamiento de Aparicio

42 "El himno Nacional y Don Pedro Varela", en La Revista Uruguaya, op. cit. n. 19, p.146.

43 Durante la campaña prerrevolucionaria de 1895-1896 Eduardo Acevedo Díaz vuelve constantemente hacia el pasado de la guerra de la independencia y de las luchas de los blancos para recuperar el ideal de la libertad como bandera de los levantamientos. Cito algunos pasajes: "levantáos del fondo del pasado, sombras veneradas que todo dispusisteis en los altares de nuestra religión política: yo os invoco también en este momento"; "en los campos cien veces regados con sangre de esta tierra...fueron más las fierezas altivas que las servidumbres cobardes"; "a los hijos y a los nietos de los que consumieron su vida en combate perpetuo para abonar el terreno de la libertad institucional; ensueño que aun proseguimos"; "porque una tierra que ha sido abonada con sangre de héroes y de mártires", citados por Eduardo Acevedo Díaz (h), en: La vida de batalla de Eduardo Acevedo Díaz, Bs. As., 1941, p. $126-128$. 
Saravia en 1897. Desde otra óptica podemos pensar que Acevedo Díaz, desde su colaboración en los alzamientos, elige conformar una tradición que lo autorice y nada mejor que destacar la íntima imbricación entre libertad y lucha, tal como se dio en las guerras de la independencia.

La tradición, lejos de situarse en un pasado clausurado o apoyar un status quo, recuerda los derechos del ciudadano y los deberes del gobernante. El golpe de estado de Latorre pone en evidencia las debilidades de Uruguay como nación democrática, la inestabilidad de sus instituciones, la incapacidad para organizar su Estado e, incluso, el peligro de la invasión extranjera. Esta situación provoca en Eduardo Acevedo Díaz un giro hacia el pasado, hacia la historia de la gesta independentista a fin de recuperar sus ideales libertarios. Ante el destierro de Agustín de Vedia por orden de Latorre, Acevedo Díaz dice "yo quiero encontrar en los misterios del pasado una virtud que hoy no encuentro, y que sea fulgura entre las ruinas de la historia como un astro que alumbra el sendero al porvenir". ${ }^{44}$ En esta cita se manifiesta la historia como una reescritura del presente, condición que si es reconocida como propia del discurso histórico, alcanza aún mayor validez para la novela histórica.

A los pocos días el gobierno lo destierra a la Argentina, donde permanece por veinte años ocupando parte de su tiempo en escribir las primeras tres novelas del ciclo histórico. En estas obras construye una imagen épica de los inicios de la patria en los que privilegia la idea de libertad, casi, podríamos afirmar, como un gesto compensatorio frente a las debilidades del presente y como una tradición revolucionaria a la cual recurrir en los períodos dictatoriales. Para ello utiliza las concepciones de Rousseau, quien le proporciona una idea romántica de la revolución estrechamente unida a la lucha armada y los principios y derechos negados por Latorre.

\footnotetext{
44 "El desterrado", en La Revista Uruguaya, op. cit., n.3, p.97.
} 


\section{Revolución: principismo y romanticismo}

J. J. Rousseau -el caballo blanco- condensa las significaciones del espiritualismo en sus múltiples dimensiones filosóficas, políticas y estéticas, y se vuelve el centro fundante de la imagen de la revolución en sus novelas históricas. La revolución entendida desde un doble perfil: como dominio de la violencia capaz de quebrar el orden colonial a través de la lucha armada; pero también como origen de los "ideales" y principios que servirán a la tarea de edificación de la joven república una vez lograda la paz luego de la independencia.

Acentúa en el ginebrino sus aspectos románticos, tal como se advierte en las siguientes citas: "él sueña siempre en los grandes ideales y en las pasiones sublimes" (1935: 73), "Recomienza su lúgubre vida errante. Vase por su tierra como un extraño, con mucha claridad oculta en el alma y con el corazón partido" (1935: 74) y "Acaso tenía razón el pobre romántico" (1935: 74).

Pero lo que me interesa aquí es el acento de rebeldía revolucionaria, de violencia desatada que señala con insistencia en las obras de Rousseau a punto tal que incluso envuelven los derechos civiles que proclama: "Y así meditando escribió El Contrato Social, formidable paradoja capaz de hundir imperios”; “(...) espíritu rebelde a la regla del hábito, agitador constante de las almas en sentido del cambio, instrumento de demolición con más poder que un ariete para abrir un sendero a la corriente evolucionista"; "Tal fue en síntesis, la vida de Juan Jacobo Rousseau, el filósofo revolucionario y el escritor ardiente que se destaca en los primordios de la lucha, acentúa con ruda energía el sentimiento de rebelión contra la fórmula clásica (1935: 79-82). Va más allá y justifica apoyado en Rousseau la lucha armada, pensada desde la revolución en la Banda Oriental de Artigas al mando de las 
muchedumbres: "En el orden social y político minó la omnipotencia de los reyes y dio armas a las muchedumbres. Sus ideas se abrieron paso en la masa como dardos de fuego, dejando en pos las chispas precursoras de un incendio pavoroso. A sus ensueños románticos, adunó las pasiones sin freno que convocó a la lucha rompiendo todo lazo de disciplina y desertando a la regla con gestos de combate" (1935: 82)

Acevedo Díaz adscribe a la figura de Rousseau este doble perfil revolucionario: por un lado destaca los principios de libertad, igualdad y fraternidad y por el otro, señala la íntima imbricación de estos derechos con la lucha armada, con los levantamientos populares; esto es, resignifica el ideario revolucionario de Rousseau desde la dictadura de Latorre para construir una tradición revolucionaria fundada en los "principios" y legalizadora de la lucha armada para defenderlos.

\subsection{El proyecto civilista}

Expulsado por Latorre en 1875, Acevedo Díaz permanece en la Argentina durante veinte años como dije. En 1895 decide retornar ante el ofrecimiento de un grupo de jóvenes para asumir la dirección del periódico El Nacional.

Dos hechos marcan su actuación política en esta segunda etapa de su vida: en 1897 se une como soldado al levantamiento de los blancos acaudillados por Aparicio Saravia y, en franca oposición al mandato de su partido, Acevedo Díaz otorga su voto a Batlle y Ordóñez en 1903, lo que le valió la expulsión del partido. Ambos episodios provocan ciertas modificaciones en su percepción de la política, que repercutirán en la novela Lanza y sable, la última de la serie, publicada en 1914.

Su participación en la sublevación de Saravia obedece al intento de defender con la guerra los valores democráticos -en especial el 
sufragio. Pero esta experiencia fracasa cuando advierte que Saravia se conforma con haber alcanzado la jefatura de seis departamentos que el partido gobernante le cede a partir de la firma del Pacto de la Cruz. El progresivo distanciamiento con el caudillo y las disidencias que encuentra en el seno de su partido cuando defiende la política sufragista frente al acuerdismo se resuelven de modo brusco con su apoyo a Batlle. La decisión del partido blanco que prefiere, ante el temor de las urnas que concitan al desorden, resolver la política por medio de acuerdos va en contra del proyecto civilista de Eduardo Acevedo Díaz. Su ruptura con Saravia cierra las puertas a la posibilidad de recuperar los derechos y defender los ideales a través del levantamiento armado. Estas desilusiones en el terreno político impregnan su última novela. Aunque no modifican substancialmente sus ideas, profundizan y expanden su proyecto civilista.

De esta nueva coyuntura me interesa analizar, por un lado, la transformación que la figura del "caudillo" sufre desde la épica de la independencia a las guerras entre las divisas; desde su dimensión heroica a su capacidad disgregadora de la unidad nacional y, por el otro, las consiguientes transformaciones en los agentes de las fuerzas de avance y retroceso que permiten el desarrollo de la historia.

\section{Las edades de la historia y las fuerzas de avance y retroceso}

Eduardo Acevedo Díaz combina, en su ciclo de novelas históricas, dos concepciones sobre la temporalidad histórica: sobre la flecha del progreso, la historia puede avanzar a través de una evolución gradual de raíz positivista o por medio de una revolución de tintes románticos que opera cambios bruscos. Ya vimos la raíz roussoneana y romántica de la revolución. Ahora vamos a introducir la idea de evolución gradual en su versión positivista. Incluye la perspectiva del positivismo -el caballo 
negro- ahora para leer desde allí la etapa de modernización y consolidación del Estado/ Nación, atendiendo a los factores "reales" del Uruguay.

Las corrientes positivistas privilegiadas en Uruguay fueron las de Darwin y Spencer, cuyas concepciones evolucionistas sirvieron para una nueva comprensión de las luchas civiles y de la evolución de la joven república -"Los universitarios positivistas desecharon expresamente los métodos revolucionarios, atemperando en política el radicalismo principista" (Ardao, 1968: 195). "Dos notas fundamentales, propias del positivismo spenceriano, aparecen en la nueva filosofía política: por un lado la necesidad de apoyarse con espíritu científico en los hechos, en las realidades históricas empíricamente observadas; por otro, la afirmación insistente de la idea de evolución" (Ardao, 1968: 265). Se comienzan a preferir los "progresos graduales" a las "revoluciones bruscas": "Los progresos graduales son los únicos positivos y duraderos (...) La lentitud de la obra no es lo que debe preocuparnos. Lo que sí debemos temer es que se arraiguen esas falsas doctrinas sobre el progreso, que buscan en una revolución o una medida pasajera el remedio heroico para combatir nuestros grandes males" (Ardao, 1968: 269)

Con estas herramientas los intelectuales procuraban un pensamiento capaz de "superar la inacabable sucesión de revoluciones, motines y dictaduras, para afianzar las instituciones y organizar de una vez la nacionalidad" (Ardao, 1968:271)

Para Acevedo Díaz también resultaba indispensable terminar con las guerras civiles para encarrilar el país en el proceso modernizador. En esto coincide con el positivismo, pero lo hace en franca oposición al gobierno de Latorre $\mathrm{y}$ es entonces cuando recupera los ideales revolucionarios. En la Revolución va a leer al mismo tiempo la etapa de 
fundación de los principios libertarios y el inicio del poder disgregador de los caudillos.

En sus novelas combina las perspectivas romántica y positivista, acentuando una u otra según el período histórico considerado. Todo el ciclo de novelas históricas de Acevedo Díaz narra la "evolución” desde la colonia hasta la constitución del Estado/ Nación y delimita diferentes períodos utilizando una terminología científica ("embrión", "desvío", "enfermedad", "herencia" entre otras). El evolucionismo le permite escandir etapas, enhebrar períodos, establecer continuidades y desvíos. Por otro lado, sus cuatro novelas exploran una totalidad de la historia oriental que él indaga a partir de la lucha entre dos fuerzas históricas: la del avance y la del retroceso, cuyos actores sociales van cambiando.

En este marco me interesa analizar la progresiva deslegitimación de la figura del caudillo en sus diversas etapas.

En las primeras tres novelas sobre el ciclo de la independencia el caudillo era el agente histórico del progreso frente a la rémora de la colonia. En el contexto de las luchas civiles entre blancos y colorados de Lanza y sable, el caudillo se convierte en freno a la difícil edificación de la nación y sus instituciones.

La colonia había sido la "etapa embrionaria", en cuya "sociabilidad primitiva" se incubaban los factores (el amor al pago, la rebeldía libertaria, el desarrollo del instinto salvaje y guerrero, el heroísmo, el caudillismo) que operarán como las fuerzas del progreso cuando se desaten las guerras de independencia frente a las fuerzas de retroceso impulsadas por la colonia. En Ismael la revolución se convierte en una sólida herramienta del progreso que necesita de todo su poder destructivo para derribar los muros de la colonia. Los gauchos y caudillos son los agentes de estas fuerzas del progreso. 
Pero allí mismo se indica el peligro del futuro, se adelantan aquellos elementos que trabarán la organización nacional. Fray Benito se pregunta por un "dique" al torrente, que frene el peligro de la anarquía y el obstáculo que el caudillismo significará en la etapa de edificación de la joven república.45

En sus primeras tres novelas domina el impulso revolucionario en la imagen roussoneana del "tourbillon" social que se aplica a la obra de destrucción. En este marco la construcción nacional aparece postergada, pero se anticipan ciertos procesos que van a "concluir por destrozar todas las formas viejas de retroceso y de barbarie para cincelar en carne viva el tipo robusto de la democracia americana". La factura de la República aparece en Ismael apenas esbozada, casi como una utopía inalcanzable en la ciudad de Montevideo que, bajo el régimen colonial, se encuentra "sin prensa, sin tribunas, sin escuela". Montevideo es la contrafigura de las ciudades patricias ilustradas hispanoamericanas que se convierten en centros irradiantes de las "teorías reformadoras que las grandes revoluciones sociales y políticas hacían llegar palpitantes a estas riberas...Montevideo carecía de este cerebro. No era un foco de ideas" (I: 7-9).

Esta tensión entre la heroicidad del gaucho y el peligro que entraña determina, en gran medida, la estructura de las novelas. Si en el cuerpo de la novela transcurren las victorias, es en los finales cuando el relato se quiebra con el anuncio de algún infortunio. La lógica contrapuesta de las fuerzas del progreso y del retroceso arman una oposición en la estructura narrativa entre el cuerpo del relato y sus finales. Veamos de qué modo.

45 En Ismael el foco intelectual está representado por el Convento de San Francisco, reconocido por su participación del lado de Artigas (Ardao, p. 27-35, "El artiguismo y la cátedra de Filosofía, en Etapas de la inteligencia uruguaya). De este modo Acevedo Díaz destaca a Artigas del resto de los caudillos por unir al heroísmo de las batallas, un foco de inteligencia. 
En Ismael, el cuerpo de la novela relata las victorias, mientras el final se quiebra con la profecía lúgubre de Fray Benito sobre futuras discordias intestinas: "La fibra de los que se han rebelado es demasiado fuerte para que el triunfo mismo suavice su fiereza (...) Conquistada la independencia, la sangre correrá en los años hasta que todo vuelva a su centro; y aún después (...) correrá también ¡Esa es la ley!" (I: 367).

En Nativa y Grito de gloria, en el escenario de la Banda Oriental convertida en Estado Cisplatino por el dominio luso-brasilero, los habitantes del desierto siguen siendo un motor de progreso necesario para la lucha contra el nuevo enemigo. En Nativa el final reintroduce el peligro. La novela perfila la imagen de la comunidad oriental en las alianzas y fraternidades que unen a diferentes sectores ante el dominio del extranjero. La amistad entre Luis María, hijo de una familia patricia de Montevideo, Cuaró, el indígena charrúa y el negro liberto Esteban postulan, de un modo un tanto esquemático, la armonía de las "razas" mientras el estanciero Robledo protege a los matreros en su hacienda y les da trabajo, sellando la integración entre las diferentes clases sociales. La patria se condensa en la figura de la gran familia. Ante el anuncio del desembarco de los Treinta y Tres Orientales, la novela finaliza con el abrazo de Luis María y Ladislao, "los dos miembros de una misma familia" que "sellaban el pacto de la cultura y de la semibarbarie", si bien se anticipa la ruptura futura: "Quizás los ideales del uno y los instintos del otro diseñaban los lineamientos de una honda división en la familia que debía operarse con el tiempo" (N: 394).

Junto a los gauchos, en Nativa y Grito de gloria aparecen otros actores que contribuyen al progreso. Luis María Berón representa el "deber ser" del patriciado; hijo de una familia ilustrada de Montevideo, emprende un viaje de aprendizaje abandonando la ciudad amurallada para experimentar los sinsabores de la vida en campaña como soldado y luego como matrero. Su acercamiento a Oribe introduce ciertos tópicos del 
discurso civilista. La oposición de las figuras de Oribe y Rivera en sus estrategias militares -el uno imponía la disciplina, la obediencia, el orden y el otro se valía de la prepotencia personal- operan como metonimias de los posteriores proyectos políticos. El hacendado Luciano Robles tipifica -adelantado en su mismo nombre- el progresismo pecuario del campo.

Al tiempo que se suceden las victorias de los Treinta y Tres Orientales en Grito de gloria, la división de los orientales se acentúa a partir de la oposición entre Rivera y Oribe. El texto cierra con los triunfos de Rincón y Sarandi que sirven de marco al duelo final de Ladislao y Cuaró, en un desplazamiento que prefigura la lucha entre las divisas. Vemos nuevamente una estructura que coloca al final el quiebre de los triunfos. Al mismo tiempo que configuran los ideales de la patria, estas novelas indagan las causas del imperio de la anarquía durante los cortos años de la historia nacional. Por ello el relato épico zozobra en la nota discordante que intenta explicar el origen y la permanencia del desorden, que corroe e impide la edificación de la nación uruguaya.

Junto al símbolo de la gran familia y sus divisiones, la bandera aparece como un ícono capaz de resumir la unión nacional contra las divisas que la disgregan. Luis María, herido de muerte en la victoria de Sarandí, tiñe con su sangre la bandera artiguista de los Treinta y Tres Orientales. La epopeya de la independencia se instaura como tradición en esta bandera que condensa la "sangre derramada", memoria y síntesis de la lucha por el ideal libertario. Acevedo Díaz articula la tradición en torno al eje de la bandera como ícono de la nacionalidad, en oposición a las divisas de blancos y colorados. El prólogo de Lanza y sable lleva justamente el título "Sin pasión y sin divisa" en un intento similar por situarse más allá de las disputas partidarias, en un lugar neutral e inmune a nuevas agresiones o quizás en el deseo de colocar por encima de las facciones una perspectiva nacional. 
Lanza y sable significa un corte en el ciclo de novelas históricas ya que ahora, finalizadas las guerras de independencia, comienza la etapa de construcción del estado/nación que el autor denomina "etapa del progreso", y es recién en este texto donde el discurso civilista adquiere la dimensión de una fuerza histórica y un proyecto político. Lograda la independencia del Uruguay, es necesario pensar la construcción de la nación a través de la consolidación de las instituciones. $\mathrm{Y}$ en este contexto el instinto destructor se transfiere a las luchas entre caudillos, a las guerras civiles entre blancos y colorados. Las fuerzas de progreso y retroceso se invierten: "el elemento regresivo que era el más considerable y primaba en los latifundios, creía de buena fe que la licencia era la libertad y que el poder del caudillo era más fuerte que el de la ley. El hecho brutal prevalente contra el principio: tal fue el carácter de la lucha en sus orígenes" (LS: 17).

En este marco Oribe y Fructuoso Rivera cumplen una función contrapuesta. Rivera representa al caudillismo autoritario y disgregador de la unidad nacional. En cambio, a partir de la figura de Oribe se despliega el discurso civilista basado en las ideas del predominio de la "ley", los "principios", "los bienes de la libertad civil y política", la educación de las masas, el respeto a la Constitución, la libertad de prensa ("tenía que empezarse por la formación de la conciencia culta del deber y del derecho, prácticas y virtudes indispensables a la organización formal del gobierno libre"). Atribuye el discurso civilista a los blancos y en este gesto condensa la tradición del partido. No obstante, el cuerpo del relato narra la guerra entre las divisas, en clave trágica. Cuaró, al servicio de Oribe mata en un encuentro a Camilo Serrano, para descubrir luego que es su hijo, punto más alto en la división de la sociedad.

En las figuras de Abel y Paula se exponen las medidas requeridas para la modernización del desierto. El progreso cuenta entre sus tareas sostener "los bienes de la libertad civil y política" (LS: 18), comenzar con 
la educación de las "clases campesinas", con la "formación de la conciencia culta del deber y del derecho, prácticas y virtudes indispensables a la organización formal del gobierno libre. Tal era la noble obra de desarrollo lento, expuesta a sucesivos desastres antes de coronarse" (L Y S, 18). Aquí se resume el credo principista de Acevedo Díaz que ahora aparece vinculado a la modernidad.

El caudillismo entorpece esta misión con los "males de la herencia", tales como el "personalismo..., el coraje indómito", la "crudeza", para concluir comprobando que "la masa vivía del resabio" y constituía una "mole de analfabetos"; "el hecho brutal prevalece contra el principio" (LS: 17-18-19). La imposibilidad de alcanzar la organización del país, por el imperio de la anarquía, caracterizó los inicios de la república como una etapa de "enfermedad" en la cual "se incubaba enfermizo el germen de la vida institucional" ( LS: 9)

Si bien Acevedo Díaz propone para el futuro el progreso, en su lectura de la historia uruguaya verifica y analiza también los movimientos de retroceso. Si una de las intenciones de su ciclo novelístico es rescatar el accionar de los habitantes del desierto en las luchas de la independencia, no menos importante es su interés por indagar las causas que retardan el desarrollo definitivo de las instituciones democráticas, esto es, auscultar las causas de la anarquía: "Es necesario hacerle relato de los lustros sombríos sin calculadas reservas, para que al fin nazcan ante sus ejemplos aleccionadores los anhelos firmes a la vida de tolerancia, de paz, de justicia y de grandeza nacional" (LS: 4). Cuando Acevedo Díaz escribe, aquellos que pregonaban la anexión exhibían como argumento la anarquía y la debilidad del Estado.

Más arriba describimos la concepción de la historia como un progreso continuo en el cual se enfrentan las fuerzas de avance y retroceso. A esta temporalidad progresiva, Acevedo Díaz, sin embargo, le 
sobrepone un tiempo circular por el cual es necesario regresar al pasado revolucionario para realizar allí dos operaciones: retomar los ideales de entonces para reinstalarlos en el presente de Latorre, pero también auscultar en la revolución el principio de la anarquía y los resabios autoritarios. ${ }^{46}$

Esta doble perspectiva frente al gaucho y sus jefes, los caudillos, como fuerza revolucionaria y como principio de la anarquía, se traduce en dos matrices discursivas casi opuestas: el gaucho como héroe épico (romanticismo) y el gaucho como "semibárbaro" (positivismo).

Antes es necesario hacer algunas precisiones. En primer lugar la importancia y centralidad que el autor otorga en su obra y especialmente en Ismael a la participación de las masas en la guerra de independencia y al problema del caudillismo. El protagonista, Ismael Velarde, un gaucho matrero que se convierte en soldado patriota, va a conducir la trama vigilado por la figura de Artigas que domina desde un segundo plano.

El problema del caudillismo y la figura de Artigas fueron un foco de debates en las últimas décadas del siglo XIX, en las cuales una serie de escritos buscaron desautorizar la leyenda negra que rodeaba su figura. Acevedo Díaz participa en estos debates con la publicación de El mito del Plata (1916), un libro tardío de las ideas que anticipa en sus novelas y donde hace la defensa del caudillo oriental frente a las opiniones de Mitre y Sarmiento. ${ }^{47}$ Articula dos argumentos para cambiar (coincidiendo sin embargo en algunas de sus apreciaciones) los términos de civilización y barbarie con que Sarmiento había condenado la realidad de los gauchos.

46 Esta confluencia de la idea de progreso con la necesidad de un retorno al pasado es característica del humanismo renacentista. Cfr. Le Goff, J., "Progreso/reacción", en: Pensar la historia. Modernidad, presente, progreso, Bs. As., Paidós, 1991, pp. 196-234.

47 Eduardo Acevedo Díaz, El mito del Plata, Montevideo, s/f. 
Sin modificar substancialmente el calificativo de "barbarie" aplicado a los habitantes del desierto, propone una explicación que vuelve necesaria y deseable su participación en las luchas de la independencia -una argumentación en clave positivista, en tanto el caudillo y el gaucho son el producto "natural" del medio (el desierto). La revolución, entendida como un acto formidable de violencia requiere un brazo abonado por las prácticas salvajes de la caza, los duelos, el rodeo, la convivencia con animales salvajes y el desarrollo de los instintos de lucha y rebeldía como factores aún más decisivos que la influencia de las ideas: "los tupamaros (...) reclamaban para sí la posesión y tranquilo goce de las soledades en que se habían formado y desenvuelto sus instintos, que en verdad, como tales, eran fuerzas más vivas y enérgicas que las ideas, y por lo mismo de acción más rápida para demoler hasta sus cimientos el edificio vetusto sin dejar piedra sobre piedra" (I: 306$)$.

Del mismo modo el caudillo es el producto del medio, por eso reconoce en Artigas "a este hijo del clima o a esta encarnación típica de la sociabilidad hispanocolonial, de cuya esencia fue el engendro" (I: 318) Invierte las tesis de la historiografía liberal porteña que acusa a Artigas de ser causa de la anarquía proponiendo al archicaudillo como consecuencia del medio.

Sin ambages, Acevedo Díaz coloca en una edad anterior a la civilización la vida en el desierto y la denomina alternativamente "época de formación embrionaria", "sociabilidad embrionaria", "los primordios".

Junto a esta argumentación de raíz positivista que explica "científicamente" el carácter primitivo del gaucho, Acevedo Díaz cruza una perspectiva romántica que hace del gaucho un héroe de la revolución. Su rebeldía, aprendida en el desierto, lo asemeja, en el sueño de Fray Benito, al "homme sauvage" de Rousseau: "L’homme sauvage se dibujó primero en mi mente bajo la forma de un solitario de las cavernas; luego 
de un centauro fiero; después, de un gaucho vagabundo" (I: 46) De este buen salvaje transformado en guerrero el autor se desliza hacia la figura del héroe de la independencia. Es el código de la épica el que permite este pasaje que, sin necesidad de desmentir la ferocidad del guerrero, lo "sublima" en un discurso de lo heroico, cuyo término final es su glorificación en el altar de la patria. Es sobre todo en las descripciones de las batallas y combates singulares donde se percibe el estilo homérico. La epopeya homérica tiene el efecto de "sublimar" la barbarie, reasumirla en un código heroico sin ocultar su semblante primitivo. Es en "Los Orientales" donde Acevedo Díaz multiplica las referencias casi como si su intención fuera colocar la representación de las guerras de independencia hispanoamericana en la tradición universal -cita a Homero, El Cid, Tasso, Ariosto entre otros, para desembocar en la formación del "altar de la patria" y las leyendas que van a conservarse "como combustible sempiterno en el fuego de la patria" (39). El culto al héroe se desliza desde la figura de Artigas para abarcar a los héroes anónimos de la independencia.

\subsection{El discurso de la abundancia}

Las múltiples y detalladas descripciones de la naturaleza sobrepasan las necesidades de diseñar un escenario para adquirir dimensiones mayores. El territorio se bosqueja a partir del recorrido que los personajes llevan a cabo y que permite la descripción de la variedad de sus paisajes. Apropiándonos de las palabras de Julio Ortega la naturaleza oriental aparece atravesada por un "discurso de la abundancia".

La representación de la naturaleza adquiere diversos significados en su articulación con otros códigos culturales. A partir del naturalismo la naturaleza -medio que determina al tipo- se vuelve rústica, fiera y salvaje 
para templar el espíritu semibárbaro del gaucho en la lucha, la figura del centauro condensa esta unión. ${ }^{48}$ Describir la naturaleza oriental significa, también, aportar un elemento más de identidad, de ahí que añada a sus imágenes los nombres indígenas correspondientes: "'Troncos gigantes enlazados por graciosas guirnaldas de lianas y tacyos...robustos yatahis y guayabos en estrecha alianza...añosos quebrachos y atrevidos ñangapirés elevando sus cúpulas en desorden..." (I: 62).

Pero aquí me interesa destacar la representación de la naturaleza en su articulación con el código de la modernidad, la exuberancia de la tierra se convierte en fertilidad agrícola, los animales en ganado y ambos en riqueza para el país exportador.99 Este modelo ingresa con la irrupción del proceso modernizador en el Uruguay a partir del último tercio del siglo XIX. En torno a él se debatió el proyecto de país agroexportador y las transformaciones necesarias para estar a la altura de las demandas del comercio exterior, cambios que incluían la tecnificación de las estancias, de los modos de industrialización y comercialización (la construcción del puerto de Montevideo, el tendido de redes ferroviarias y la centralización del poder político y económico en la gran urbe capitalina).

48 Cfr. Nativa: El clima que nutría el germen del guayabo, del "yathay" y del ombú para alzarlos muy arriba de modo que sus copas recibiesen y soportasen el empuje del pampero, era natural que diera vida también y la misma indómita energía al hombre que debía ocupar la escena"..."Y fue del seno de los bosques en los tiempos aciagos, que surgieron los caudillos más intrépidos, de la propia hechura del matrero, como exceso de savia de una naturaleza pródiga que daba el valor a los hombres en la misma medida que la audacia, por motivo igual que daba dureza y gigantesca talla al ombú, al guayabo y al "yathay". ¡Eran todos frutos del clima y prole del "pampero"! $(248,149)$.

49 El factor económico adquirió importancia en la definición de las naciones de los ideólogos del liberalismo burgués triunfante entre 1830 y 1880 , ya que éstas debían demostrar su viabilidad y formar parte del progreso humano. Este factor alcanzaba aún mayor importancia en el caso uruguayo ya que se trataba de una nación pequeña. Hobsbauwm arguye el rechazo a las naciones pequeñas ("principio del umbral") bajo el requisito de la incapacidad de un amplio desarrollo económico: "el principio de nacionalidad era aplicable en la práctica sólo a nacionalidades de cierta importancia (...) La autodeterminación para las naciones sólo era aplicable a las naciones que se consideraban viables: cultural y, desde luego, económicamente", op. cit., p. 41. 
Como ya vimos, Acevedo Díaz adhiere a muchos conceptos del positivismo, pero no acuerda con un gobierno fuerte necesario como etapa dado el estadio evolutivo de la sociedad; de allí que no apoye la dictadura de Latorre. Por el contrario incluye como elemento indispensable del progreso la pronta consolidación de las instituciones democráticas, más cercano en esto al ideario principista. ${ }^{50}$

Este modelo, por obvias cuestiones de anacronismo, sólo aparece en las novelas proyectado hacia el futuro, a través de un sueño utópico.

En el siguiente fragmento se vinculan los tres discursos analizados: la tesis de la independencia clásica, el discurso de la abundancia y el código civilista. Luis María, en muchos sentidos el alter ego de Eduardo Acevedo Díaz, le relata a Oribe sus sueños patrióticos: "El país solo y libre...¿Quimera?....No hay duda que por ahora es un problema el de la independencia absoluta. Somos pocos y pobres; esos pocos desangrados... ¡Pero cuántos sacrificios! Bien valían ellos una autonomía completa. El país pequeño, población reducida, rivales poderosos que se lo disputan; todo eso es cierto. Sin embargo, mañana...Vea usted mi comandante. ¿No hay aquí grandes riquezas inexplotadas, aparte del pastoreo y otras industrias que darían envidia a los más fuertes el día que salieran a la superficie? ¿No hay pasión por la tierra, lujo de valor y de heroísmo; no hay conciencia de lo que se anhela de un modo constante?...Yo he soñado alguna vez que esas riquezas eran descubiertas, que el país se henchía de vida y que venían de otros lejanos a sus puertos numerosas gentes, que se esparcían luego a la orilla de sus

50 En su primer novela, Brenda (1884), cuya acción tiene lugar en la década de 1870 , Acevedo Díaz reúne en el personaje principal, Raúl Henares, estas dos tendencias. Del lado del positivismo, como ingeniero, apoya el proceso modernizador del Uruguay pero a la vez critica tanto un positivismo estrecho que desconoce los ideales como al sector evolucionista que apoya a la dictadura. A la vez este personaje está imbuido de altos ideales. Zelmar lo describe retomando la imagen de los dos caballos: "tú eres el caballo blanco (...) símbolo de inexplicables anhelos y de ideales vagorosos" (p.29). 
ríos sin semejantes, sembrándola de ciudades orgullosas y veía en sus campos feraces llenos de luz y de verdor eterno, treinta millones de toros; en sus canales escuadras enteras con todas las banderas del mundo; un mar de espigas y de viñas en sus vegas; emporio de comercio en sus playas admirables; solidaridad nacional, leyes justas, historia gloriosa, culto por los mártires y los héroes... Era mi sueño" (GG: 117).

De esta cita quiero retomar ciertos elementos que condensan otras significaciones del proyecto modernizador del autor. En primer lugar, la utopía cientifica, que reúne las matrices romántica y positivista; luego me voy a detener en dos símbolos que sintetizan esta utopía -la muralla y la Enciclopedia- que apuntan a la revolución y a la educación, y finalmente consideraré la necesidad de una política basada en el crecimiento de la población siguiendo las conocidas ideas de Sarmiento y Alberdi.

\section{Utopía científica}

En "Juan Jacobo" y "Diderot" reconoce Acevedo, aunque señalando sus diferencias, la idea de un progreso en la historia, acentuando en Rousseau el sueño utópico y en Diderot una concepción de tipo evolucionista. "Digna era la obra de quien nunca dudó de la utopía, sin haber jamás descendido al análisis de la miseria humana al favor de la ciencia inquisidora" (EAD, 1935:83), afirma de Rousseau, para luego sintetizar y contraponer el pensamiento de ambos: "El uno representa los anhelos grandes y vagos del espíritu sin tipo conocido, de emoción pasional, pero nada coherente con la realidad de la vida; el otro encarnaba la aspiración al cambio por la natural virtud del esfuerzo humano, por el estudio de los hechos positivos y la coherencia de la ayuda propia con los medios científicos de mejoramiento" (EAD, 1935:92-93)

En la confluencia de estas dos tendencias, Acevedo Díaz retoma la concepción de una utopía científica. Siguiendo las tendencias europeas, el 
discurso utópico cambia de tono, abandona el discurso ficcional y las ciudades fantásticas para entroncarse con la historia, con los proyectos políticos, con los mitos fundacionales del Estado-Nación. ${ }^{51}$ Fueron Fourier y Saint-Simon quienes dieron un nuevo sentido a la utopía al refundarla desde la ciencia (luego, Marx le negará este carácter). La utopía adviene como el punto final de un progreso evolutivo de la sociedad, adquiere su garantía en las leyes naturales y sociales recientemente descubiertas.

Es Luis María Berón quien formula la visión utópica en la cita que ya hemos transcripto. $\mathrm{Su}$ personalidad representa la tensión entre ambas tendencias al ensueño y a la vida práctica, sin lograr armonizarlas del todo en una unidad, sufriendo constantes vaivenes y padeciendo enfermedades hasta su muerte. De él hace el autor un retrato romántico -“alto, delgado, de rostro fino, cabello rubio en ondas, frente amplia, ojos azules" (N: 110)- aunque dotado de cierta fortaleza. Propenso al ensueño y poseedor de una fértil imaginación, concibe la "patria" como una visión interior: "la patria que él se había fijado en sus adentros y cuya imagen rara guardaba como un ensueño dulce y querido, no estaba allí dentro de los muros" (N: 127). Este ideal patriótico lo resuelve a emprender una acción anclada en la realidad, a conocer por la vía de la experiencia la ruda vida de la campaña en la lucha contra el dominio luso-brasilero. En sus primeras experiencias en el desierto padece la ferocidad del medio, se agota en sus esfuerzos hasta sufrir una crisis nerviosa, con visiones extravagantes de una naturaleza agigantada por los delirios febriles $(\mathrm{N}$ : 212).

Luis María representa la figura del héroe idealista que procura llevar a la praxis su "ideal luminoso" (N: 211); es el encuentro, entonces, de una doble tendencia romántico-realista que da lugar a su visión

51 Baczko, Bronislaw, Los imaginarios sociales. Memorias y esperanzas colectivas, Bs. As., Nueva Visión, 1991. 
utópica. Por otra parte, esta tensión es característica de los héroes de las novelas históricas de Walter Scott, si pensamos en Eduardo Waverley en continuo conflicto entre sus tendencias románticas y la lucha en el campo de batalla. Varias novelas latinoamericanas reiteran este modelo de "héroe mediocre" (Lukács), de ellas el ejemplo de Abel en Durante la Reconquista de Blest Gana, sería un descendiente digno del modelo. Es que una de las funciones de este personaje consiste en articular la doble dimensión que divide estas novelas: la trama romántica y los avatares de la historia.

\section{Muralla y Enciclopedia}

Una de las propuestas básicas del proceso modernizador es el desarrollo de la educación que en Uruguay tuvo a Varela como su promotor y que Acevedo Díaz entronca con la figura de Diderot y su Enciclopedia. Al comienzo de Ismael, en un Montevideo aún colonial, aparecen dos imágenes que pueden servir como líneas que recorren el resto de sus novelas: la muralla y la Enciclopedia, Rousseau y Diderot.

La ciudad de Montevideo está "encerrada en sus murallas de piedra" (I:1), símbolos del sistema colonial, que van a ser derrumbadas por obra del desvastador influjo roussoniano. Al mismo tiempo se trata de un Montevideo que carece de "colegio o instituto científico" (I: 3 ), tarea que se llevará a cabo bajo las reformas positivistas y que, como vimos, el autor vincula con Diderot. El relato se va a ocupar de destruir la muralla como acción privilegiada de la revolución y de proponer la educación como tarea indispensable en la etapa de consolidación del estado/ nación.

La destrucción de la muralla metaforiza la idea de "revolución", como quiebre en la temporalidad histórica que permite así el avance histórico. La revolución en Ismael, presentada por los sueños visionarios de Fray Benito quien se inspira en la lectura de Rousseau -cuya obra 
considera "una máquina de destrucción, pequeña pero de potencia descomunal" (I: 97)-, acentúa el estrago. E1 "barreno", la "mina”, “el torrente", el estallido" son las típicas imágenes de violencia revolucionaria, que se condensan en el sueño revolucionario de Fray Benito, en el cual una doncella prometida en matrimonio a un español muere cuando un grueso proyectil derriba la "pared" del salón, metonimia de la muralla (I: 41)

Abel y Paula, ambos habitantes de la campaña, representan el progreso en el desierto. Abel recibe como herencia la estancia, anticipación de las demandas que el impulso modernizador requerirá del Uruguay como país agroexportador de materias primas. Ya el autor lo anticipa en el prólogo de Lanza y sable: "Hoy el hombre de campo se reforma, se instruye, se va despojando a grados de la vieja corteza hereditaria" (6). En este presente de la escritura, el gaucho ya ha desaparecido, pero al contrario de lo que Rama observa en Martín Fierro, no se trata de un canto de cisne que glorifica a un sector ya perimido en el intento nostálgico del sector hacendado, por el contrario, para Acevedo Díaz, el gaucho ha desaparecido, pero su historia ha modelado parte de la nacionalidad y del genio del pueblo oriental.

Por su parte, Paula logra superar su condición de "rústica" ("arisca", "brusca" y "retraída"), heredada del medio agreste en que nació, gracias a la educación. De algún modo es la contrafigura de Fructuoso Rivera, su padre, superado aquí por su hija. El autor adelanta ciertas cualidades de Paula que le van a permitir abrirse al progreso: su sensibilidad vence al instinto, su inteligencia facilitará su educación y la moral será el elemento indispensable para acceder al respeto de los principios constitucionales y de las leyes ("a un fondo de sensibilidad moral que más adelante debía tomar gran vuelo, unía ella un espíritu sagaz (...) merced al cual había de aprender a leer y escribir"). A todo ello, se sumaba "la finura de los sentidos" y "algo de superior a lo que la 
rodeaba, acaso una tendencia soñadora” (LS: 39). Laureana se ocupa de la educación que vehiculiza esa transformación: “Antes era rosa de cerco, ahora soy de jardín" ( LS: 308)

No hay que olvidar que la principal reforma educativa fue implementada por el positivismo en Uruguay a través de la actuación de Varela y Vásquez Acevedo, en especial el desarrollo de los estudios científicos que venían a cubrir la carencia señalada por Acevedo Díaz en Montevideo de "colegio o instituto científico".

El ciclo completo de las novelas pone en paralelo dos acciones convergentes, dirigidas alternativamente a Montevideo y a la campaña. En el ciclo independentista de las novelas anteriores, el viaje de aprendizaje debía realizarlo el intelectual a fin de experimentar, como Luis María, "los verdaderos hálitos de la patria" que se mantenían vivos sólo en la campaña. En su última novela la protagonista Paula -hija rústica y agreste del pago- aprende a leer y a escribir con la ayuda de Laureana. En este doble camino, Acevedo Díaz da su propia respuesta a la oposición entre "caudillos" y "dotores" con una imagen conciliatoria que habla de la necesidad de integrar la ciudad con el campo.

\section{Del "pago" a la "patria": la figura del forastero}

Dos espacios simbólicos, dos modos de organización territorial y social, son claves en la representación de la historia uruguaya de Acevedo Díaz: el pago y la patria.

El pago es la "patria en embrión" (LS: 225) de los tiempos primordiales, dominada por el "amor al pago" de los gauchos, en tanto instinto de pertenencia a la tierra que habitan. La revolución es el primer paso hacia su conversión en "amor a la patria", que sólo puede hacerse realidad cuando en la joven república se suspenda el poderío disgregador 
del caudillismo para arribar a la unificación nacional. Si Fructuoso Rivera es quien va a representar el pago ("la concepción de la patria se confundía con una intensa pasión terrígena”), sólo durante el gobierno de Oribe "el espíritu nacional empezó a sentirse" (LS: 27-28). Una de las tareas de los gobiernos nacionales es la unificación del poder bajo el Estado y la ley, tarea que implica el final de los poderes locales que los caudillos defienden. La bandera y las divisas son sus correspondientes símbolos.

La figura del "forastero", que reaparece en más de una oportunidad, va a ser clave en este pasaje del pago a la patria. La introducción del "forastero" en el pago desarma las relaciones estancas, destruye el poder establecido abriendo las puertas a nuevos juegos, corroe la atomización de poderes propugnada por el caudillo que se siente dueño de la tierra impidiendo el fortalecimiento del Estado nacional. Proyectado hacia el futuro, el forastero se confunde con el inmigrante, cuya figura celebra Acevedo Díaz al comienzo de Lanza y sable.

Dos escenas exponen las significaciones del forastero. La primera es un cuento de Anacleto, capataz de la estancia de Robledo, narrado a Dora y Nata: una moza del valle, Ubalda, rechaza insistentemente a todos los pretendientes del lugar para enamorarse finalmente de un forastero. En venganza los mozos del pago lo matan, provocando también la muerte de ella.

El anverso de esta historia se encuentra en Lanza y sable, cuyo protagonista Abel aparece como el "forastero" en una festividad del pago para finalmente conquistar el amor de Paula, codiciada por los mozos lugareños, con un final, ahora promisorio. La inversión no es casual, la unión de ambos protagonistas constituye un modelo de progreso en su capacidad para evolucionar desde el espacio del pago y de la sociabilidad primitiva anclada en los instintos hasta las puertas de un superior estadio 
evolutivo: la organización de la joven república, marcada por la educación de Paula y la herencia que Abel recibe, una estancia "de porvenir".

El tópico de la "herencia", característico del naturalismo, es clave en el proceso evolutivo de ambos. Paula se entera de que es hija de Don Frutos Rivera en un capítulo significativamente titulado "Fenómenos de la herencia", pero logra quebrar ese determinismo hereditario mientras en Abel la pesada herencia de los instintos se sustituye por la herencia de una estancia.

La herencia de instintos, usos, costumbres, amores y odios del hombre del desierto, si fecunda en la época revolucionaria, se vuelve lastre a superar en beneficio del progreso del país. "Saber las cuatro reglas ya es mucho; pero vencer los cien resabios de la herencia, no es obra de una generación", se dice en Lanza y sable.

\section{Romanticismo y realismo-naturalismo}

Estas tensiones que venimos analizando alcanzan a definir la factura de su prosa y la modalidad de los narradores en sus novelas. La tensión y confluencia del principismo y del positivismo se resuelve en una prosa que alterna rasgos románticos con otros realistas-naturalistas..$^{52}$

En "Diderot" -el caballo negro- Acevedo Díaz trama la línea que va desde el Enciclopedismo al positivismo y al naturalismo de Zola, con el uso de la "observación" y el "experimento" en un estilo literario dominado por "la viveza, la sequedad y la precisión" (EAD: 1935: 86). Si los románticos se ocuparon de "lo bello y lo sublime", los naturalistas

52 Arturo Ardao, en "La evolución filosófica de Acevedo Díaz", zanja los debates sobre el carácter romántico o realista de la producción de Acevedo Díaz proponiendo la doble pertenencia y la asocia a la evolución de su pensamiento desde el espiritualismo al positivismo, posiciones compartidas en este trabajo. 
introdujeron el "cúmulo de fealdades y miserias, de instintos y apetitos desordenados de la masa, inquieta siempre por su destino, primando en ella con el sentimiento de conservación propia la crudeza del egoísmo, la desigualdad de clase, el orgullo de raza, la bajeza de origen, la injusticia cruel, el dolor ignorado y los dramas palpitantes del crimen" (EAD: 1935: 88).

También podemos analizar este cruce problemático en la presencia de dos narradores en todo el ciclo narrativo, que, si bien comparten el carácter omnisciente en tercera persona, se diferencian por el uso de los registros discursivos. Un narrador, que podemos llamar "literario", se ocupa de relatar la acción novelesca, mientras otro de carácter "científico" -y me apropio aquí de un término utilizado por el mismo autor- indica, interpreta y explica lo que ocurre en la trama ficcional, introduciendo digresiones.

En el narrador literario predomina un entramado épico que al final suele quebrarse con notas trágicas, ordena entonces los sucesos distribuyendo las acciones gloriosas y los peligros. El narrador positivista debe dar cuenta de esta articulación entre el rostro progresista y los gérmenes retrógrados de los tupamaros. Es un narrador culposo que mantiene una relación no siempre cordial con su par.

Me voy a detener en algunos momentos que ejemplifican estas tensiones en su prosa: las escenas amorosas y la naturaleza.

\section{Las escenas amorosas}

Otro cruce, un tanto esquemático, entre romanticismo $\mathrm{y}$ realismo-naturalismo se verifica en la representación de los personajes que aquí abordaré en sus vínculos amorosos, trabajadas estéticamente 
según el rango que ocupan en la sociedad. Forman triángulos amorosos que representan las relaciones entre diversos sectores sociales.

El lazo entre Ismael y Felisa, ambos productos del pago, se representa según la estética del realismo-naturalismo. Los instintos conforman el factor que desencadena la escena amorosa en un juego que se reduce a los cuerpos para culminar, con la aparición de Almagro, en la pelea por la mujer. "Los alientos del varón le encendían la sangre, quemándole todo el cuerpo, y se abandonaba sin resistencia, acercando y retirando su cabeza del pecho de su amante, con esos movimientos bruscos al principio, pausados luego, de una voluntad que se rinde". Por su parte, Ismael "el gaucho vigorosos que domaba potros, era en aquel instante lo que el clima y la soledad lo habían hecho, un instinto en carnadura ardiente, una naturaleza llena de sensualismos irresistibles y de arranque grosero" (I: 127-128).

El triángulo entre Natalia, Dorila, hijas del hacendado Robledo, y el patricio Luis María Berón, se narra bajo los presupuestos románticos, al igual que sus retratos. Las muchachas poseen modales delicados, ofrecen su piedad y cuidado ante los males de Luis María, se inclinan a los "ensueños", "vuelos de la imaginación" y "anhelos secretos". Luis María les otorga el valor de la diferencia: "no son zafias" (N: 110). Una de ellas, Dora, padece una enfermedad nerviosa, cercana a la epilepsia, con sentimientos angustiantes, presa de melancolías y desmayos a causa de los cuales muere en un remanso. Las escenas amorosas entre Natalia y Luis María se encuadran en el "idilio", con el previsible freno a los instintos por parte del varón "tratándose de una joven educada y honesta" (316), y el libre vuelo del espíritu, en el marco trágico de la muerte de Luis María.

La tercera relación, la de Paula y Abel, se narra en un punto intermedio, una combinación equilibrada entre instintos y espíritu. La 
escena amorosa pone en juego la "sensualidad" y "seducción", el recato y la osadía, el instinto y el sentimiento, el cuerpo y la emoción, la dulzura, el beso y la mirada, con dosis de picardía y alegría, alejada del clima trágico de los casos anteriores.

\section{La naturaleza}

Las descripciones de la naturaleza oriental abundan en estas novelas obedeciendo a variados intereses e intercalando dispositivos románticos y naturalistas. Las peculiaridades del medio, el "color local" del romanticismo, se hace presente como corresponde a una novelística dedicada a la configuración de una literatura nacional que represente las realidades del país. En Nativa la naturaleza se vuelve un motivo de inspiración para el arte popular del "trovador de pago" y del "bardo errante" (N, 251). La acumulación de términos nativos entrecomillados y explicados en un léxico forma parte del intento de fijar sus peculiaridades.

Pero la naturaleza es también, y ahora en la línea positivista, el medio que determina la índole de sus pobladores y del país. Una serie de descripciones presentan el costado salvaje del monte, de la selva, de las montañas y la llanura recorridas por animales bravíos y hombres semibárbaros.

El discurso modernizador imprime a la naturaleza el plus de riqueza que Luis María imagina para el futuro agroexportador de la nación, tal como ya hemos analizado.

Como factor formador de los pobladores es que la naturaleza adquiere valor decisivo, ya que no sólo involucra a los habitantes del desierto, sino que se constituye en una experiencia educadora necesaria para la clase intelectual, los futuros gobernantes, los sectores urbanos, 
todos los cuales deben conocer la realidad de la campaña para integrarla a sus proyectos políticos. Una de las críticas que Acevedo Díaz parece formular al principismo consiste en su desconocimiento de los factores reales del país. Su propuesta incluye la necesidad de conocer a través de la experiencia la vida de la campaña, expresada en sus novelas por el recorrido que Luis María Berón inicia en su deseo de aprehender la patria no sólo como una idea: "la 'patria' que él se había forjado en sus adentros (...) no estaba allí dentro de los muros (...) los verdaderos hálitos de vida de esta patria, los ecos enérgicos de sus sublimes rabias mal domadas, venían de afuera, de sitios que no conocía, quizás de campiñas llenas de sol y de pampero" (Nativa, 127) En medio de esa experiencia en la rudeza y realidad del medio, Luis María se burla de la falsa naturaleza cantada por los poetas del romanticismo (Nativa, 165-166).

El análisis del ciclo novelístico de Acevedo Díaz sirve como telón de fondo para medir los cambios y rupturas que las novelas históricas de la posdictadura le imprimen. Es contra la idea de un discurso fundacional y contra la épica de los orígenes que estas novelas van a reaccionar. 


\title{
III ¡BERNABÉ, BERNABÉ! DE TOMÁS DE MATTOS O LAS NUEVAS CARTOGRAFÍAS DE LA HISTORIA
}

\author{
"Se terminó el tiempo de los grandes pontífices \\ que decian dónde estaba el bien y dónde el mal \\ e impregnaban su mundo narrativo con ideología." \\ Tomás de Mattos
}

La publicación de ¡Bernabé, Bernabé! (1988) de Tomás de Mattos desató un cúmulo de polémicas y controversias sobre los héroes de la independencia en varios semanarios y secciones culturales de conocidos periódicos uruguayos. Se convirtió en el punto de arranque de una serie de novelas históricas que reescribieron obsesivamente los eventos más violentos del siglo XIX: las luchas entre las divisas y facciones, la dictadura de Latorre y la de Santos, la guerra de la Triple Alianza repoblando aquel siglo de esbirros, matones, dictadores y militares.

En esta relectura del siglo XIX se cifra la voluntad de una indagación raigal de las causas o antecedentes que expliquen la última dictadura. ¡Bernabé, Bernabé! resulta, en este sentido, una novela ejemplar porque, por un lado, reescribe el origen de la nación a contrapelo de la épica de la independencia al señalar en ese mismo origen el genocidio de los charrúas. Por otro, esta novela no se limita al origen, establece vínculos con otros períodos en que se implementaron políticas estatales autoritarias. Diseña una nueva cartografía de la historia uruguaya que va hilando las diversas dictaduras que atravesaron su historia, señalando el fuerte peso de la casta militar en los destinos del país. La revisión del origen y la reescritura global de la historia hablan de la profunda fractura que significó la última dictadura. 
La "herida" de la dictadura tuvo también entre sus consecuencias, como ya adelantamos, el quiebre de los imaginarios sobre la "Suiza de América", "El país más democrático de América Latina" provenientes del batllismo. La crisis de identidad suscitó una doble tendencia: el cuestionamiento de aquellos valores democráticos que ahora tambaleaban y la recuperación simbólica de los sectores disgregados de las políticas nacionales ("indianidad" y "africanidad"). Ambos problemas se complementan íntimamente en la crítica a las políticas autoritarias responsables de las pérdidas sociales y culturales.

¿Bernabé, Bernabé! reinterpreta el siglo XIX desde esta agenda de la posdictadura, pero además incluye temas más precisos, tales como la ética militar, la obediencia debida, la teoría de la aniquilación, el problema del juicio, la importancia de la memoria, articulados todos alrededor del eje de la crisis y búsqueda de identidad. ${ }^{53}$ Desde esta perspectiva me interesa indagar de qué modo la novela reescribe la historia de la campaña de exterminio de los charrúas en el marco de estos debates que han configurado el reciente período de la posdictadura uruguaya.

\subsection{La trama temporal. Los recuerdos del porvenir. Hacia un} mapa de las dictaduras

¡Bernabé, Bernabé! articula de modo visible cinco tiempos:

1- Los sucesos del "pasado" narrados por Josefina abarcan de 1811 a 1826 y de 1831 a 1832 , incorporando la participación de Bernabé Rivera en las guerras de Independencia y en la campaña de exterminio charrúa.

53 Las citas de ¡Bernabé, Bernabé! de Tomás de Mattos corresponden a Ediciones de la Banda Oriental, Montevideo, 1994. 
2- Un tiempo más o menos indeterminado, aunque limitado entre dos fechas: la juventud de Josefina y el momento en que ella escribe (1885). En este tiempo se sitúan las cenas, reuniones y conversaciones que ella mantiene con su padre (Máximo Péguy), su marido (Juan Pedro Narbondo), Fructuoso Rivera, Melchor Pacheco y Obes, Gabiano, etc. en su casa y que son recuperadas a través de la memoria de Josefina. Esta etapa sirve de puente entre los acontecimientos históricos narrados y el presente de su carta, a través de la cual rememora los rasgos vivenciales de sus interlocutores y el mundo familiar en que sucedieron. ${ }^{54}$

3- El año 1885, cuando Josefina escribe su relato para Federico Silva, cargado de una atmósfera luctuosa provocada por la muerte de su esposo el año anterior y por la política sangrienta del presidente Máximo Santos.

4- La fecha en que el ficticio editor M.M.R. escribe su prólogo, 12 de octubre de 1946, pone en contacto el descubrimiento de América con el juicio de Nuremberg, señalando el parentesco entre dos etnocidios perpetrados por los europeos pero no ajenos a la historia del Uruguay.

5- El momento en que Tomás de Mattos publica su obra, diciembre de 1988, pocos años después del fin de la dictadura uruguaya.

Esta pluralidad temporal no es azarosa, conforma ciertos ordenamientos significativos. La novela diseña un recorrido de la historia uruguaya, a través de la elección -y conexión- de determinados momentos claves. Bernabé Rivera y la campaña contra los charrúas ingresan a la historia por su lado más oscuro e indican en los inicios de la independencia una política de exclusión y exterminio llevada a cabo por el gobierno y la casta militar. Como señala el editor, de ese primer

54 Pocas veces Josefina señala con precisión ese pasado, sí lo hace cuando recuerda el momento en que pintó el retrato de Bernabé: "veinte años atrás". 
período "esos dieciséis años, que fueron la fragua de nuestro destino" (22-23), Josefina elige sólo algunos momentos que ponen en escena la heroicidad de Bernabé, como la batalla de Sarandí, punto culminante de la virtud del guerrero pero asimismo origen de su abrupto descenso.

Reescribe la historia como una tragedia a partir de la figura de Bernabé o, casi mejor, convierte a la epopeya nacional y a su héroe en un héroe trágico de estirpe sofóclea El editor destaca el corte y la selección que Josefina lleva a cabo para diagramar el ascenso y caída de Bernabé Rivera: "Es significativo que desde 1826 se salte, sin más, a 1831. Quedan por el camino no sólo cinco años capitales en la vida de la República, porque en ellos se procuró la doble frustración de la separación de la Provincias Unidas y de la mutilación del territorio que debió asignársele, sino también los días más gloriosos de los Rivera, quienes en una campaña que antes que una sucesión de éxitos militares fue un relámpago incontenible de adhesiones, liberaron y reincorporaron las Misiones Orientales a las Provincias Unidas (...)" (23).55

Si bien el año de escritura de la carta por parte de Josefina -1885no aparece representado, la penetra escueta aunque significativamente con la referencia a "las mezquindades del presente". Su crisis de identidad está provocada por la presencia de la violencia: "Tan sólo sé que me asedia un impulso idéntico al que una tarde me ató a un charco de sangre, en cuyo copioso espejo, sobrevolado por las moscas, entreveía confusamente el reflejo de mi cara y el cielo" (28-29). Este segundo período resulta significativo en la historia del Uruguay como momento culminante de lo que se ha llamado el "militarismo" que, inaugurado con la toma del poder por Latorre (1876) alcanzó su más nefasta etapa

55 A tono con la perspectiva crítica de Josefina, en esta cita el editor califica de frustraciones a eventos históricos que, como la separación de la Provincias del Río de la Plata, la historiografía suele interpretarlos como actos de independencia, forjadores de la nación uruguaya. 
durante el gobierno de Máximo Santos (1882-1886). ${ }^{56}$ Esta década tiene una doble direccionalidad. Hacia el pasado cierra de algún modo la época de la anarquía y las luchas civiles a partir de una política que, en vistas al futuro, procura consolidar un estado moderno y centralizado. Josefina percibe los costos de esta modernización, llevada a cabo mediante prácticas violentas; del mismo modo cuestionará la campaña contra los charrúas: "¿La modernización de nuestros campos pasaba necesariamente por el exterminio y la disolución de los charrúas?" (58). La pregunta por la identidad formulada en el marco del gobierno dictatorial de Santos se vuelve hacia las primeras décadas de la historia uruguaya para encontrar una respuesta o el origen que la explique. La reiterada presencia de los militares en ambos períodos de fundación y modernización del país va pautando un recorrido ajeno a ciertos imaginarios sobre la democracia uruguaya.

La fecha del prólogo del editor MMR, 1946, remite al genocidio nazi y al juicio de Nuremberg, estableciendo una filiación entre la historia europea y la uruguaya. Podemos presuponer también la alusión, aunque débil, a la historia uruguaya, pues en 1946 el Presidente Juan Amézaga (1943-1947) había restituido recientemente la democracia luego de los dos golpes de estado, de Gabriel Terra (1933) y de Baldomir (1942).57

56 Cfr. "Latorre apostó, como vimos, por los inversionistas y los terratenientes. Sin escatimar el rigor. Vergara es fusilado, con varios compañeros, porque se le supone desafecto. Eduardo Beltrán es muerto por la guardia en medio de la calle. Mata es asesinado. Mayada también. El cuerpo de Mariño, ejecutado, aparece en el río. Igual sucederá con Frenedoso. Soto es ultimado por el Coronel en persona. Irigoyen es envenenado. Ibarra, en San José, Ledesma, en Río Negro, y Coronado, en Salto, son ajusticiados. 'Nadie ha visto nada, nadie ha oído nada, nadie recuerda nada' ", sobre el gobierno de Santos el autor resume "Asomemos primero a lo más negativo: el autoritarismo, la cruda intolerancia partidista, la violación abierta de los derechos más elementales (...) se repiten abusos y atropellos, torturas, homicidios, proscripciones" en: Historia de los orientales, Tomo 2: De la Guerra Grande a Saravia, Montevideo, Ediciones de la Banda Oriental, 1992, p. 175 y 181.

57 Resulta curiosa -o significativa- la cita de otro período dictatorial que en 1976 hizo el Ministro de Economía y Finanzas, Vegh Villegas sobre el futuro tal cual él lo deseaba "Veo al período "terrista" extenderse hasta 1980, con un "Baldomir" 
El editor MMR cumple la función de primer lector de los papeles de Josefina y se arroga la tarea de orientar posibles lecturas. Así reactualiza el tema de la identidad y su puesta en crisis por parte de Josefina acorde a los debates de su presente. Apunta obviamente a suscitar una interpretación similar en los lectores actuales de la novela. ¿Cuáles son, entonces, las operaciones de una correcta lectura? El editor coloca bajo la mira crítica dos de los imaginarios fundantes de la identidad uruguaya: la "diferencia" y la permanencia de los valores de la "democracia".s8 Si la "diferencia" de los uruguayos con respecto al resto de los países latinoamericanos los acercaba a los europeos por su alto nivel cultural y la falta de un fuerte legado indígena, MMR reformula esta filiación y nos advierte que Uruguay no está a salvo de los crímenes que se cometen "en todas las latitudes". Desde su perspectiva, el genocidio charrúa se recoloca -en tiempo y espacio- en un mapa mayor, al vincularse con el Holocausto (posterior y europeo) para recalar en la conquista de América (anterior y latinoamericana). Si la cita del genocidio nazi ha sido un referente privilegiado para comparar ciertas prácticas de la dictadura, esta novela la incluye desde una trama ampliada. Las palabras del editor también socavan las ideas en torno a un Uruguay "chiquito pero pacífico" y respetuoso de las instituciones democráticas, e instalan la saludable advertencia sobre el peligro de la construcción de un imaginario autocomplaciente o narcisista. La revisión y puesta en crisis de los relatos legitimadores que sustentaron $\mathbf{u}$ ocultaron extremismos ideológicos y políticas autoritarias ha conducido hacia una

cubriendo el período 1980/85 y un "Amézaga", con pleno funcionamiento de los partidos tradicionales y del nuevo régimen, de 1985 en adelante" Cita de la "Carta de Vegh Villegas a Bordaberry", enero de 1976, extraída de: Breve historia de la dictadura de G. Caetano Y J. Rilla, Montevideo, Claeh, 1991, p. 47.

58 En el primer capítulo ya revisamos la importancia de estos debates en la configuración del espacio de enunciación de la posdictadura. Estos imaginarios se trabajan, asimismo, en: "Introducción" de F. Devoto a Identidad uruguaya ¿mito, crisis o afirmación?, op. cit; De mitos y memorias políticas, de Carina Perelli y Juan Rial, Montevideo, EBO, 1986.; H. Achugar, La balsa de la Medusa, op. cit. 
relativización de las "verdades" que los fundamentaban. Siguiendo este enfoque, el editor apela a la "duda" como lugar desde el cual se puede sortear la barbarie.

El último tramo de este itinerario histórico nos remite a la última dictadura, que se cuela en la novela a partir de ciertas homologías y referencias.

Este recorrido por los gobiernos militares, las prácticas autoritarias y las violencias de estado perfila una diferente lectura de la historia uruguaya. La perspectiva oficial prefería relatar la epopeya independentista de las primeras décadas del XIX y, posteriormente, los procesos modernizadores que posibilitaron entre fines de ese siglo $\mathrm{y}$ comienzos del XX la consolidación de una nación homogénea, librepensadora, progresista, democrática y culta. Josefina, MMR y, en definitiva, Tomás de Mattos, eligen leer a contrapelo el pasado. Incluso, si el relato de la historia se configura como tragedia en torno a Bernabé, adquiere dimensión de farsa cuando Gabiano relata la manipulación del pueblo que Don Frutos hace a propósito de la muerte de Bernabé para impedir la sublevación del comandante Juan Santana el 29 de junio de 1832.

Si bien delimitamos todo un movimiento cuyas fechas claves entronizan el peso del sector militar a lo largo de la historia uruguaya, el texto privilegia la relación entre dos momentos, la campaña de exterminio contra los charrúas y la última dictadura. La novela plantea un diálogo entre ambas a través de múltiples vinculaciones, desde la presencia de los actuales debates en torno a la identidad que se filtran en las evaluaciones de Josefina sobre la historia de Bernabé y los charrúas hasta las homologías y paralelismos de ciertos elementos que, referidos a la campaña contra los indios, remiten a sus pares de la dictadura. 
Si se evita el uso de anacronismos deliberados, el horizonte del presente de la escritura de Tomás de Mattos (1988) opera como una grilla que selecciona, incluye o excluye, prefiriendo focalizar ciertos eventos y temas de la historia del siglo pasado, para leer en clave las preocupaciones actuales. ${ }^{59}$ La novela se distancia de un "anacronismo deliberado" en tanto tiende a borrar las marcas del presente de la escritura y desplazar la crítica hacia Josefina y el editor, respetando la unidad temporal en que cada uno se sitúa. Para ello el autor escoge a un personaje lo suficientemente excéntrico como para hacer verosímil sus ideas: una mujer de carácter inquieto y enjuiciador que, en el ámbito doméstico de una familia patricia, se relaciona no sólo con los hombres de la clase dirigente, sino que, además, revisa el archivo de su marido, referentes indispensables de la versión oficial.

\subsection{La identidad en crisis. Del espejo narcisista al charco}

El problema de la identidad se configura a partir de una serie de imágenes que tienen como eje el espejo. Se contraponen dos caminos posibles: el espejo narcisista de aguas transparentes, y aquellas aguas turbias y ensangrentadas de un charco. Si Josefina se contempla en "el charco de sangre" para indagar una identidad que presupone la comprensión de la violencia y la muerte; Bernabé inicia su carrera cultivando su propia imagen, se pasea "empilchado, entre oros y mármoles" en la corte de Río de Janeiro, "igualito a Narciso" comenta Josefina. En su inicio la novela coloca dos modos alternativos de conformar una identidad.

59 En una entrevista a cargo de Ana Inés Larre Borges, De Mattos dice "El verdadero anacronismo es que una mujer del siglo XIX cuente una historia que es en realidad la visión de un hombre del siglo XX.", Brecha, año VII, n. 358, 9 de octubre de 1992, p. 19. 
En la batalla de Sarandí -punto culminante de la gloria militar para Bernabé Rivera- aparece un indiecito charrúa quien, huérfano, adopta el nombre de Bernabé. Esta escena -deliberadamente ficcional, como nos aclara Josefina- desplaza la imagen especular de Narciso para incluir al "otro" (los charrúas) en la superficie refractante del espejo. La alianza entre Bernabé y los indios está refrendada por la paternidad que el indio huérfano solicita al coronel. Se postula, por un momento, la posibilidad de construir una comunidad, aunque paternalista, armónica. Simultáneamente se adelanta la destrucción de esta ilusión con la anticipación del rol final del indiecito en la muerte de Bernabé: "Me voy pero te aseguro que vuelvo. No te hablaré más, pero me verás cuando revolee la boleadora: me he ganado un lugar en esta historia" (41). En esta primera parte se insiste en las buenas relaciones con los charrúas, que acentúan el posterior carácter de traición.

Una identidad "narcisista", fundada en la ignorancia del otro, posibilita el exterminio de los charrúas emprendido por Bernabé e incuba, al mismo tiempo, los motivos que lo llevan a su destrucción. El héroe narcisista se ahogará en el espejo de sangre que él ha creado siguiendo los imperativos militares.

El texto no sólo propone el problema de la identidad en Bernabé; ya que Sepé, Polidoro, el cabo Joaquín y el indio Bernabé introducen y desarrollan el tema del lado de los charrúas. La novela plantea la necesaria vinculación de ambos en el origen de la conformación de la nación y procura restaurar la "visión de los vencidos", la contracara de las versiones oficiales, mediante el relato de las acciones y reacciones de los charrúas para su supervivencia.

La hipótesis de Josefina sobre la identidad del matador de Bernabé combina y confunde las versiones de Lavalleja y Antonio Díaz, apropiándose de los agentes que ambos señalan -Polidoro, Sepé, el cabo 
Joaquín y el indio Bernabé- para reformular el problema de la identidad dentro del ámbito charrúa.

Siguiendo la interpretación de su padre, "Polidoro" representaría la primer etapa del charrúa "Sepé", quien adaptó un nombre extranjero en momentos en que la tribu compartía ciertas alianzas con Artigas e, incluso, posteriormente con los Rivera. Luego de las masacres que comenzaron con Salsipuedes, Sepé reasume su condición de charrúa junto con su nombre ("Sepé era también, como ya te he dicho, una palabra charrúa") para llevar a cabo una política de resistencia haciendo honores al nombre de "uno de los jefes más destacados de la rebelión guaraní" (105). Josefina lo explicita claramente: "Para papá, Polidoro y Sepé eran, entonces, una sola persona que había cambiado de nombre. Creía comprender los motivos: el temor a la venganza de Don Frutos y, sobre todo, la necesidad de cortar todo vínculo con nuestra raza y de reasumir en plenitud, su condición de indio" (105).

El problema de Sepé es la identidad y permanencia de los charrúas como etnia en un medio que les es hostil e intenta aniquilarlos. Grupo minoritario y de escaso poder político debió seguir los vaivenes impuestos por la política dominante, de allí que en momentos de frágiles alianzas cambie su nombre por el de Polidoro. La resistencia y el separatismo, no obstante, caracterizaron sus costumbres. ${ }^{60}$ Sepé reasume su verdadera identidad para su tribu en el último esfuerzo por sobrevivir; profundamente desconfiado, se niega a negociar con Don Frutos en Salsipuedes. Con el único puñado de sobrevivientes decide vengarse por el exterminio de los suyos en la persona de Bernabé. Perdidas todas las batallas, Sepé se instala con los restos de su gente cerca de la estancia de Gauna y busca medios de sustento. Su treta, aquí, será la del débil, quien

60 Abundan los datos que expresan la resistencia de los charrúas a dejar sus costumbres, desde su participación en las tropas de Artigas peleando y acampando por separado, hasta las negativas de Sepé a vestirse al uso cristiano, hablar el castellano, utilizar dinero o reconocer el derecho a la propiedad. 
falto de espacio para maniobrar actúa con una doble identidad y un doble discurso ("Polidoro, gran cacique; Sepé, pobre indio"), esconde su participación en la muerte de Bernabé aprovechando la lógica ambigua del lenguaje: "Sepé, no; Polidoro, sí"; "Sepé...pa vos...". Según comentarios de Péguy, Sepé "se burlaba secretamente de los cristianos" (106).

Sólo decide confesar la verdad a raíz de la leva y la viruela que lo deja sin familia y sin esperanzas para su tribu: "Desde esa época, según los que presumían conocerlo bien, trasuntó varios cambios. Aunque nunca se le oyó ningún comentario, don Higinio sostenía que al indio lo abatía la certidumbre de que muertas sus hijas y cristianizada la única nieta sobreviviente, la tribu carecía de futuro. Era muy improbable que la descendencia que engendraran Avelino y Santana viviera según las costumbres charrúas" (108).

En el indio Bernabé se verifica un giro similar al de Sepé en la búsqueda de su identidad, aunque difiere en la función del nombre. En la batalla de Sarandí, la adopción del nombre de su jefe marca la alianza de Bernabé Rivera con los charrúas, huérfanos de padre político. Rota ésta por el coronel, será su propio hijo adoptivo quien le devuelva su rostro de traidor y fratricida. La conservación del nombre Bernabé impone la figura del doble y la imagen del espejo donde el victimario encuentra su destino de víctima al invertirse los roles.

Josefina añade a la hipótesis de su padre una tercera identidad de Sepé, la del cabo Joaquín, quien sigue el mismo derrotero de sus compañeros y recupera su ascendencia charrúa con la participación en la muerte de Bernabé: "Siente el pecho lleno de vida; está limpiando su pasado; ha vuelto a ser un charrúa entre charrúas. En silencio y lentamente, le va arrancando, una a una, las lanzas que tiene clavadas" (142). La convergencia de múltiples nombres charrúas en la escena de 
muerte de Bernabé le concede a ésta la dimensión de un acto colectivo asumido como único destino posible.

El ostensible trabajo con el "nombre propio" en esta novela es otro registro (además del espejo) de la identidad. Por un lado, la imposibilidad de articular el nombre propio en el interior de la comunidad charrúa sometida a los vaivenes de una política que los excluye del edificio nacional, se vehiculiza a través de la errancia nominal ya analizada (Sepé, Polidoro, Joaquín, el indio Bernabé). Por el otro, el indio Bernabé introduce la figura del "doble" en el mito de Narciso y provoca la escisión del "sí mismo" por la intromisión del "otro" en la lámina opuesta del reflejo. Bernabé Rivera lo desconoce y, atrapado en su propia imagen, escinde la alteridad indígena con su brutal empresa persecutoria.

El título de la novela, "iBernabé, Bernabé!", condensa las imágenes del doble y las inversiones del texto; reitera el nombre propio para librar su diferencia, lo repite especularmente para mostrar su ruptura. El grito dibuja este recorrido, es proferido por el indiecito ante el entusiasmo por la victoria de Sarandí para culminar en boca del mismo coronel cuando aquél lo atrapa. ${ }^{61}$ La imagen especular, hecha trizas en el charco de sangre, recuerda la pérdida de una identidad compleja (heterogénea) en los inicios de la nación.

El encuentro final reúne la muerte de Sepé con la de Bernabé en la pulpería. Mientras Sepé aún conserva la luz -"todavía estalla y seguirá estallando la luz de la vida"- como un gesto de apertura que no sella en la clausura del pasado la extinción de los charrúas (la "esperanza" es, además, una de las notas fundamentales de la escritura de Tomás de Mattos); el rostro de Bernabé trueca ese cielo por el turbio espejo del

61 Cuenta Gabiano sobre el coronel: "yo lo oí gritar y lo oí clarito y reconocí su voz. Estoy seguro que gritó: ¡Bernabé! ¡Bernabé!" (126) 
charco donde encuentra la muerte y su identidad. ${ }^{22}$ Josefina recién aquí recupera, en este itinerario por la víctima y el victimario, su propia identidad. La identidad recobrada y comprendida adviene, entonces, a partir del espejo turbio en sangre y no de las aguas claras del espejo de Narciso.

\subsection{La ética militar}

Bernabé encarna el ethos militar -"se desveló por ser un militar inobjetable"- caracterizado por una exacerbación -desmesura- en el cumplimiento del deber, un extremismo que desemboca en su teoría de la aniquilación y que le confiere dimensiones de héroe trágico.

En las primeras acciones Bernabé aparece en su fase ascendente y heroica. Uno de sus puntos culminantes, la batalla de Sarandí, sirve de marco para formular la teoría de la "aniquilación" que Bernabé sustenta y pone en práctica con la tropa de Allen Castro: "Si toca perder hay que perder apenas; si se gana hay que ganar por aniquilación. Por eso ninguna batalla termina cuando el enemigo se retira. Toda baja que todavía le causemos, todo hombre que se rinda, toda arma o caballo que le quitemos, es un hombre, un caballo o un arma que mañana o pasado no tendremos enfrente" (38). El mismo método que utilizará con los charrúas y que luego éstos se apropian para aplicarlo en su contra -"La adhesión de Bernabé a este principio, le reportó varios éxitos, le granjeó parte de su fama y también lo precipitó a la muerte" (38).

62 Resulta clara la presencia en esta novela de rasgos característicos de Borges: el tratamiento de la relación entre victimario y víctima, el reconocimiento de la identidad en el momento de la muerte, la relación entre el traidor y el héroe, así como las reflexiones de Josefina sobre el destino a través de la imagen del juego del ajedrez. 
La desmedida heroicidad de Bernabé tiene esta doble cara, manifiesta en las sucesivas victorias que culminan con el grito "!Bernabé, Bernabé, Bernabé!", pero que incuban el principio que lo llevará a la muerte. Su caída sigue los resortes del héroe de la tragedia griega: el ethos militar se convierte en hybris, transgrede "los límites del orden último del mundo", el héroe enceguece y "pierde el tino". La feroz persecución ${ }^{63}$ de Polidoro lo convierte en un cazador -";Ya los tenemos a esos perros"- que termina ocupando el lugar de la presa ("murió solo, como si fuera un perro", p.138). ${ }^{64}$ La identidad del coronel se resuelve con una anagnórisis final que le devuelve su rostro: "Engendró odios que, desde el mismo inicio de su cautiverio, lo privaron de toda posibilidad de sobrevivencia. No fue clemente $y$, en la última hora, el turbio espejo de un charco le devolvió su imagen" (113).

El delito de Bernabé es el fratricidio, desplazamiento del parricidio de Edipo, cuya culpa es leída en clave de los ochenta como desmesura de los imperativos del ethos militar -"virtudes" dirá M.M.R. apelando a las reminiscencias maquiavélicas del término.

En esta teoría y práctica del exterminio se sustenta la crítica fundamental tanto de Josefina como de M.M.R. La palabra "aniquilación"

63 La persecución de Bernabé a Polidoro mantiene un contrapunto con la persecución de Melchor Pacheco y Obes a Bernabé, como un anticipo en clave paródica. Melchor emprende su búsqueda cometiendo todo tipo de torpezas, "una sarta de chapetonadas", impulsado por el deseo de no encontrarlo y, menos aún, de derramar sangre, termina atrapado por Bernabé.

64 Cfr. pág. 94: "Al comentarle: 'El que anda escondido por Yacaré-Cururú es el cacique Polidoro', lo zumbaron igual que se zumba a un perro. Yo lo miraba y no lo creía. Desde ahí hasta el final quedó frenético. Yo nunca le había visto perder el tino'. El militar claudicó. Toda su mente quedó nublada por la pasión del cazador. La presa que se le había escapado por dos veces, estaba a su alcance". Las continuas alusiones a los perros en toda la novela, vuelven sobre el tema de la identidad. En una primera instancia, los "perros" conforman la tropa de Artigas, en especial los charrúas aludiendo a su salvajismo y barbarie, luego constituyen un motivo central en el relato de Gabiano quien, obedeciendo al capataz, termina enterrando a los cachorros, con quienes luego identificará a los charrúas, y finalmente serán parte del destino de Bernabé ahogándose en el charco "que ni siquiera lamerían los perros" 
recuerda el decreto del Presidente argentino Luder (1975) que los estamentos militares hicieron suyo bajo el lema de "aniquilar a la subversión". Cuando Bernabé prueba tímidamente este ideario con la tropa del general brasilero Allen Castro, sugestivamente la palabra "picana" define las lanzas de sus hombres: "se precipitaron sobre los brasileros, los encerraron en un círculo utilizando las lanzas como degradantes picanas" (40). La lanza-sable-espada va a ser un tópico que a lo largo de la novela simboliza los valores del guerrero junto con sus excesos. El arma preferida por Bernabé sustituye por dos veces al fuego de las balas. En Sarandí, Bernabé se destaca por su arrojo al impulsar a la tropa a luchar cuerpo a cuerpo: "A balazos no venceremos a los brasileros. Para triunfar no hay otro medio que echar carabina a la espalda y sable en mano" (38), y de igual modo reprende a Gabiano en su último enfrentamiento con los charrúas ("Bernabé se enojó. '¡Con el sable, sargento! ¡Para qué desperdició su pistola!", 95). Es su espada, ya rota, lo último que figura cuando los charrúas lo cercan y atrapan. Esta lanza-sable-espada simboliza la exacerbación de su carácter militar, acompañando el arco de su vida.

El perfil del militar -en tanto perspectiva aportada por la posdictadura- rearticula la figura del héroe de la independencia, convirtiendo su areté en preceptiva militar fundada en la obediencia y el exterminio del enemigo.

\subsection{La obediencia debida}

La apertura democrática abre el debate sobre el grado de culpabilidad de los militares por su atropello a los derechos humanos. Mientras las cúpulas pueden ser acusadas como "responsables" por lo 
actuado, los subordinados procuran apelar a la "obediencia debida" para eludir el juicio. ${ }^{65}$

La novela retoma ambos temas. Josefina cita los argumentos de la defensa -enarbolados por su padre y por su marido- que intentan evitar toda inculpación a Fructuoso Rivera por el exterminio de los charrúas: las teorías basadas en la dicotomía civilización y barbarie, la lógica de la guerra, la necesidad histórica y el pedido y apoyo de amplios sectores sociales (52 a 59). Concluye Narbondo que "nadie -se llamase Rivera, Oribe, Lavalleja o Garzón- podía ser responsabilizado. Por el contrario Josefina atribuye la "responsabilidad" a Don Frutos: "Pero sí puedo decir que esas matanzas me avergüenzan y que, en última instancia, a él son atribuíbles, porque las decidió, planificó y dirigió. No es poca carga para una conciencia" (58).

En cambio la posición de Josefina frente a los "de abajo" difiere ostensiblemente. El tema de la obediencia debida aparece en dos oportunidades, en torno a Bernabé y a Gabiano. En ambos casos el relato se centra en el proceso por el cual cada uno de ellos debe sortear las dudas y vallas que le impone la conciencia para internalizar la "obediencia debida". Se reitera la mirada característica de Josefina, interesada en señalar la dimensión subjetiva de los hechos históricos.

En los momentos preliminares a Salsipuedes, Bernabé reúne a sus principales hombres para informarles sobre la próxima acción -una traicionera celada- contra los charrúas, pero al recordar la obligación de obediencia no logra soslayar los vaivenes de su conciencia: "Lamentablemente, se habrán dado cuenta que no los llamo para pedirles opinión (...) Sinceramente esto es algo que parece una canallada y cuesta mucho prestarse a hacerlo (...) Para serles sincero, no estoy enteramente convencido. Pero quienes deben estar resueltos, lo están, y tenemos que

65 En una entrevista a Tomás de Mattos se explicita esta conexión con el tema de la "obediencia debida". Cfr. Brecha, año IV, n'. 158, 25 de noviembre de 1988, p.27. 
obedecer todos. Si a mí me duele, descarto que a ustedes les va a ocurrir lo mismo y peor (...) Camaradas: ésta es la vida del militar." (67). Si resulta un poco sorprendente que Bernabé se coloque casi a la misma altura de un subordinado, desplazando su responsabilidad hacia la obediencia, será Josefina la encargada de poner en duda las reservas de Bernabé frente a las órdenes de sus superiores para sospechar "una sutil y mañosa manipulación de los ánimos de sus principales subordinados" (68)

Gabiano da su propia versión sobre la obediencia debida recordando un suceso de su infancia para justificar la traición a los charrúas en Salsipuedes. Siendo niño, fue obligado por su capataz a enterrar, aun con vida, la cría de su perra. Si al principio se negó, terminó obedeciendo y asumiendo como propias las reglas impuestas. El relato de infancia presenta el proceso por el cual Gabiano interiorizó esta práctica de la obediencia anulando toda duda. Es sugestivo, además, que el tema de la obediencia sea un punto de coincidencia entre Gabiano y Bernabé, evidenciando el sentido corporativo de los militares a través de un sujeto que se desliza de un "yo" a un "nosotros": "Yo...Nosotros no atacamos a traición. Hicimos lo que nos mandaron y lo que nos mandaron fue una emboscada y una emboscada es muy común que se haga en la guerra" (54). Las reflexiones finales de Josefina en alguna medida relativizan la culpabilidad de los estamentos inferiores cuando concluye: "Creo que la historia por más simple que nos parezca admite más de una lectura. La que más me afecta es la que me obliga a ver clarito lo que en otras ocasiones consigo que me pase desapercibido: el horror total de un hecho no es igual a la suma de los horrores menores, suscitados por cada uno de los actos necesarios para causarlo. Por eso quien se negaría sin titubeos a ser su autor, puede aceptar -casi sin darse cuenta- ser uno de sus coautores" (62-63). 
La ética militar, la teoría de la aniquilación y la obediencia debida, en tanto parte de la agenda de la posdictadura, se vuelven -en esta noveladispositivos para revisar los antecedentes históricos de la última dictadura eslabonando puentes y continuidades; pero también sirven para criticar las versiones "heroicas" de los orígenes nacionales sustentadas en "identidades narcisistas".

\subsection{Las diversas historias. El Archivo Narbondo y el relato de los charrías}

Junto al anterior recorrido por la historia uruguaya, la novela presenta otra perspectiva sobre el tiempo, en la que se enfrentan $y$ complementan el tiempo en que sucedieron los hechos históricos y el tiempo en el cual aquellos hechos se representan, se escriben. Esta relación y esta tensión se reitera en los diferentes enunciadores. ${ }^{66}$ Pero aquí sólo me voy a detener en el caso de Josefina quien relata la historia de Bernabé y los charrúas desde el clima de violencia instaurado por Máximo Santos.

66 De hecho este texto presenta dos narradores, el editor M.M.R. y Josefina, quienes escriben dos textos diferentes. El editor se apropia, ficcionalizándolo, de una función y un género textual, el prólogo, que podría haber estado en manos de T. de Mattos. Por otro lado, el editor nos presenta a la narradora Josefina, su vida, sus obras, y es quien edita ;Bernabé, Bernabé!, identificando ahora a Josefina con T. de Mattos ya que dentro de sus obras también se encuentran algunas del autor. Desde otra perspectiva, la compleja relación entre el editor, Josefina y el autor se establece a partir de la coincidencia espacial y de la diferencia temporal: el espacio de escritura: Tacuarembó para M.M.R y el autor; San Fructuoso, antiguo nombre de aquél, para Josefina, resulta un punto visible de coincidencia; en cambio -como ya vimos- los tres escriben en diversos momentos conexos estre sí, ya que registran la experiencia próxima de un período dictatorial: los últimos años de la dictadura de Santos en el caso de Josefina y el siguiente período democrático en el editor y en T. de Mattos, períodos que otorgan a cada uno una visión desencantada sobre la historia. Tomás de Mattos habla sobre "Este desencanto que siento en mí mismo y que percibo nítidamente en muchos de los que me rodean" en: "La empresa y las identidades uruguayas", Identidad uruguaya: ¿mito, crisis o afirmación, op. cit. p. 137. 
Entre ambos tiempos se instala una mediación cuya función consiste en poner en escena y discutir las posibles vías para aprehender la historia: el uso de fuentes oficiales junto con versiones alternativas, la pluralidad de puntos de vista, la oposición escritura/oralidad, la importancia de la memoria y la idea de "juicio". El extenso período que se despliega entre los hechos que relata Josefina (1811-1832) y el presente de su escritura (1885) resulta el caso más significativo ya que permite dilucidar el cómo de la tarea de historiadora que la narradora asume. En el caso del editor, más escueto, es la idea del "juicio" la que modeliza el modo en que el pasado se evalúa.

La novela no sólo narra los hechos, voces diversas y contrapuestas los discuten en diálogos acontecidos en casa de Josefina, los cuales despliegan el problema del dialogismo a través de un movimiento que se desplaza desde la imposición de una perspectiva hasta la ruptura de esa univocidad para crear el difícil juego de la multivocidad.

Las opiniones se caracterizan por su pertenencia a diferentes sectores sociales, a disímiles espacios de enunciación que traman la tensión entre lo privado y lo público; a opciones genéricas -lo masculino/femenino-, y a diferentes canales de transmisión (el documento escrito y la oralidad). Josefina escenifica el cruce de versiones en los diálogos con su padre Máximo, su esposo Narbondo, don Frutos, Pacheco y Obes, Gabiano, etc., asumiendo claramente la voz crítica y disidente ante la versión oficial de su padre y de su marido. Pero aun las opiniones de éstos admiten matices y críticas parciales -"signos de disconformidad"- a la guerra contra los charrúas que, reconoce el padre, "tuvo aspectos horrorosos". Narbondo concede que no fueron los charrúas quienes mataron a los peones, muchachos de once y catorce años, en la hacienda de José Canto. Estas críticas, no obstante, en ningún momento corroen la defensa que hacen de la campaña de exterminio contra los indios. El texto no presenta deliberadamente el predominio de 
una voz sobre las otras a la hora de discutir las razones históricas de cada sector sobre los hechos, lo que hace es darles coherencia y contextualizarlas según el rango social y la ideología del que la emite. ${ }^{67}$

Josefina no deja de formular sus propias opiniones, pero a la hora de comparar recoge las ajenas, las cita y suele concluir con una interrogación, una duda a la que añade un juicio ético. Este juicio aparece como el momento de predominio de su voz sobre el resto, pero, paradójicamente incluye, sin anular, las diferentes razones políticas. ${ }^{68} \quad \mathrm{El}$ mejor ejemplo lo constituye el final del texto que multiplica las imágenes según la óptica del que las interprete: "¿A cuál Bernabé hay que rememorar? ¿Al de Sarandí o al de Salsipuedes? (...) ¿Al victimario o a la víctima? (...) Ahora oigo múltiple aclamaciones: '¡Bernabé! ¡Bernabé!' Pero ¿cuáles son las voces solitarias o confundidas en la algazara, que enronquecen repitiendo ese nombre? (...) También veo incontables imágenes. Por ejemplo muchas manos de mujer: la de Manuelita, contrayendo su duelo (...), la de una india (...) dejando que un desertor lleve los muñones de sus dedos" (148).

67 Cfr, por ejemplo, p. 31: "cuando en una sobremesa no quise refrenar un tercer elogio casi consecutivo de don José Artigas. Al oírlo, don Frutos se sonrió pero veló su rostro con una expresión de pena y nostalgia y deslizó este comentario: 'Verdaderamente... lo que podrían ser todas estas Provincias si Don José hubiera sido un poquito menos obcecado' ". Ana Inés Larre Borges analiza el juego de las diferentes versiones a través de la técnica del contrapunto cuyo último fundamento estaría en la duda: "Y podríamos afirmar que es en esencia ese procedimiento [el contrapunto] -que como materialización de la duda abarca el nivel ético, narrativo e informativo de la novela- la manera como se construye el ;Bernabé...! de De Mattos". Brecha, Año IV, No. 166, 27 de enero, 1989, p.26.

68 Cfr.: "¿Era ése, en verdad, el único camino? ¿La modernización de nuestros campos pasaba necesariamente por el exterminio y la disolución de los charrúas? Y, aún admitiendo que fuera la única opción ¿es lícito proseguir la marcha cuando la salida que se vislumbra es notoriamente injusta e inhumana?" o esta otra cita de la página 68: "¿qué es peor? ¿qué es más censurable? ¿La ejecución de una aberración, sin previa mensura de su real alcance? ¿O su consumación, a pesar del constante asedio de la propia conciencia? ¿Las decisiones de la guerra sólo requieren a la lógica? ¿Es recomendable, en aras de una mayor eficacia, aislarlas de toda consideración de justicia? ¿La disciplina es siempre la máxima virtud marcial?" (58-59) 
El diálogo y la oralidad son los medios que hacen posible la crítica, en oposición al Archivo Narbondo, versión oficial, escrita y conclusa. El Archivo sirve para justificar la campaña de exterminio: "Andá y revolvé los papeles de tu marido y te vas a encontrar con copias de órdenes de Lavalleja, con informes de Garzón y con una carta de un maestro de Paysandú que te van a demostrar que, en aquellos días, no había nadie influyente que no considerase imprescindible acabar con los charrúas" (52). ${ }^{69}$

El Archivo representa las voces autorizadas que intentan legitimarse como la opinión pública, conformadas por la casta dirigente de los destinos de la nación, desde el presidente de la nación Fructuoso Rivera y los militares Bernabé o Garzón, junto a los hacendados como José Canto, hasta el educador José Catalá. Su legitimidad emana de su connivencia con el poder, aunque a veces se escude en la representatividad de los intereses del pueblo, una figura abstracta, cuya heterogeneidad y divergencias se niega o se desconoce: "A menudo me dijo Narbondo: 'No podés negarlo, Josefina. Al atacar a los charrúas, Don Frutos acató la voluntas del pueblo'. Alguna vez le pregunté a qué pueblo se refería, porque juzgo que en cualquier país, hay tantos pueblos como bandos o fracciones." (57). Se contrapone la historia escrita por los vencedores a una oralidad que procura rescatar una perspectiva que incluya a los vencidos.

Aquí ingresa el tema del etnocentrismo, los derechos de las minorías y el problema de la "diferencia" en la configuración de la

69 Cfr.: "Una tarde me abrumó con copias de muchos documentos que estaba recopilando. Ahora, los tengo conmigo, sobre este escritorio, a mi izquierda, cosidos en legajos de distinto espesor. Acabo de leer un expedientillo, que él tituló "el clamor de los hacendados". Son oficios, partes, editoriales o cartas que casi nunca están firmados por estancieros: más bien encuentro maestros, párrocos, jefes políticos y hasta receptores de Aduana. Todos tienen un tema en común: alguna tropelía cometida por los charrúas".(55). El Archivo Narbondo es citado para refrendar las opiniones oficiales, lo que resulta una argumentación circular en tanto esos textos fueron escritos por los defensores y agentes de la campaña contra los charrúas. 
nación. Retomando las categorías sarmientinas, su padre postula la idea de una nación homogénea construida a partir del eje de la civilización y que necesariamente debe extirpar de su cuerpo todo aquello que encarne la "diferencia". El etnocentrismo, que eleva a carácter universal los valores de su propia sociedad, propone dos alternativas a las etnias diferentes: una política de asimilación a sus propios valores o de exclusión de los elementos heterogéneos. ${ }^{70}$ En ningún caso se admite la inclusión de lo diferente con iguales derechos a la hora de conformar la nación:

"Los charrúas no nos dieron la Patria"; "Mi padre insistía que la alianza con los indios fue 'muy circunstancial y azarosa'. Los objetivos de ambos pueblos no sólo son distintos, sino incompatibles. Para los charrúas, la libertad era la perduración del Desierto: tierra sin cultivar, ganado sin cuidar, barbarie compartida. Para nosotros, la libertad era la posibilidad irrestricta de que cada ciudadano volcase el mayor esfuerzo para el progreso de su familia, amparado por las máximas seguridades de que serían sólo suyos los legítimos frutos de su esfuerzo". Estas citas fundamentan la política de exterminio, mientras se señalan los intentos de asimilación: "Me recordó varias veces que todo indio que aceptó nuestros valores, 'fue respetado y tratado como uno más de nosotros"' (54)

El Archivo Narbondo está tomado de La guerra de los charrúas en la Banda Oriental, en especial el tomo II, de Eduardo Acosta y Lara, si evaluamos la pista dada por Tomás de Mattos en una nota. Dicho archivo está conformado en su mayor parte por documentos de la época (partes de guerra, informes, cartas, notas aparecidas en periódicos de la época, etc.), además de un Apéndice con la "Memoria" de Manuel de Lavalleja y el

70 Cfr. T. Todorov, Nosotros y los otros, México, Siglo XXI, 1991; AAVV, De palabra y obra en el Nuevo Mundo, Madrid, 1992; Zea, Leopoldo, Discurso desde la marginación y la barbarie, Barcelona, Anthropos, 1988; AAVV, El otro, el extranjero, el extraño, Revista de Occidente, $\mathrm{n}^{\circ}$. 140, 1993; Bartra, Roger, El salvaje en el espejo, México, Era, 1992. 
relato del exterminio de los indígenas de Antonio Díaz (hijo) en su obra Historia política y militar de las Repúblicas del Plata, tomo II, y que coincide con la versión de Acevedo Díaz, ya que ambos utilizaron como fuente las referencias del General Antonio Díaz. En el texto de Acosta y Lara se encuentran tanto la versión oficial, sobre todo en los partes de campaña y en las notas periodísticas, como la versión contrapuesta en los relatos de Lavalleja y Antonio Díaz.

Pero en la novela ambas versiones incompatibles se representan de diverso modo. El Archivo Narbondo elimina los relatos de Lavalleja y A. Díaz y se conforma con los partes oficiales y las notas de los periódicos, esto es, funciona para sostener la versión oficial y pública de los hechos, la defensa de la campaña de exterminio. Josefina describe cómo estos documentos ocultan la verdadera historia que pone al descubierto la barbarie de los hechos cometidos: "Los partes mienten y callan con descaro, los periódicos de esos días, son más obsecuentes que los de hoy. No hay base documental alguna para acceder a la verdad" (69); "Los detalles del episodio son aún más escurridizos que los de Salsipuedes. Los documentos son parcos (...) La prensa no le dio al combate demasiada resonancia" (88). Los documentos muestran las discontinuidades o la precariedad que acecha a las certezas de la historiografía: "El material que puedo alcanzarte es fragmentario y heterogéneo, con la única excepción, si el sargento Gabiano y yo merecemos tu confianza, del que concierne a los hechos de Salsipuedes y Yacaré-Cururú, de los que puedo proporcionarte, además de los vericuetos de la historia oficial, una versión inédita, mucho más feroz y veraz, que barrunto no te agradará demasiado" (29).

Josefina opone a esta versión documentada y escrita por los mismos autores de los hechos, la versión oral del sargento Gabiano que si bien coincide con los relatos de Lavalleja y Díaz del texto de Acosta y Lara, en la economía de la novela no pertenece al Archivo Narbondo, se 
le opone. Se invierten los términos y la oralidad de Gabiano aparece como la voz preeminente con la cual coinciden los textos escritos, dice Josefina: "Pero, sobre todo dispongo de lo que ha narrado Gabiano en nuestra casa: para creerle, me bastaría su sola palabra, porque fue un hombre bueno y sin mucha imaginación, que -por añadidura- tenía pocas vergüenzas que ocultar. Es sumamente alentador que muchos de los detalles aportados por él, encuentran corroboración explícita en las memorias de Lavalleja o los Díaz" (69)."

Por la voz de Gabiano no sólo ingresan los hechos ausentes en los partes de campaña y que van a conducir el hilo de la narración, sino la historia narrada por los mismos charrúas, de allí que Josefina privilegie el texto de Lavalleja en tanto transcribe el relato de los vencidos; "Doy más crédito, sin abandonar una actitud sanamente crítica, a los recuerdos de Manuel de Lavalleja, quien, si bien tampoco estuvo en Salsipuedes, convivió con los charrúas sobrevivientes durante diez meses en 1833 y ha afirmado que la conversación dominante entre ellos siempre era el ataque de Don Frutos y la ejecución de Bernabé" (69), del mismo modo lo confirma el propio Lavalleja en su "Memoria": " lo sé por los mismos indios ejecutores, de quienes me he informado muy detenidamente, de los indios más capaces que había entre ellos; diez meses estuve con ellos en el año treinte y tres y siempre era la conversación dominante del modo que mataron a Bernabé". ${ }^{2}$

A través del relato de su padre, Josefina recupera, además, la voz de Sepé, a quien aquél le oyó confesar su participación en la muerte de

71 La sugerencia de esta versión oral del sargento Gabiano se encuentra en Acosta y Lara, La guerra de los charrías en la Banda Oriental, Montevideo, Librería Linardi y Risso, 1989. Allí se dice: "Consideramos la posibilidad de que exista (...) alguna declaración del sargento Gabiano o Galeano, que fue el que trató de que Bernabé montara en ancas de su caballo para escapar de los indios...", (120).

72 Cfr. Eduardo Acosta y Lara, La guerra de los charrúas en la Banda Oriental, op. cit., Tomo II, p. 193. 
Bernabé. De este modo el texto opone claramente la ecuación: historia escrita/ historia de los vencedores/ versión oficial a historia oral/ historia de los vencidos/ versión no oficial. A este juego de oposiciones se van sumando otras. Evidentemente, el Archivo Narbondo es "patriárquico" (no sólo es obra de su marido, en él su padre refrenda sus opiniones y además reúne las voces de los "padres" fundadores de la patria) y allí Josefina se entromete para desbaratarlo desde una enunciación femenina. Inserto en la casa familiar de los Péguy, este archivo público se privatiza, se recoloca en un ámbito doméstico desde el cual la narradora lo interpela.

Si bien el Archivo Narbondo representa la perspectiva oficial, Josefina cita sus documentos para diferentes funciones: un uso referencial de los partes le sirve para jalonar los momentos de la historia; cita los documentos que utilizan su padre o marido para apoyar sus opiniones, en este caso Josefina a veces se distancia ${ }^{73} \mathrm{o}$ tiene una actitud irónica; $y$, finalmente, ejerce una apropiación, con mirada oblicua, de los documentos citados. Este resulta el caso más interesante. Por un lado, Josefina recupera los intersticios que estos textos rara vez muestran, para comentar las zonas más oscuras de la campaña contra los charrúas, como, por ejemplo, cuando en un parte Bernabé llama a la celada de Salsipuedes "jarana contra los charrúas" (68). ${ }^{74}$

En otras ocasiones no lee en los textos datos históricos sino los residuos de las subjetividades que la historia descarta, los detalles, las

73 En una oportunidad desmiente la versión de Catalá sobre Polidoro como traidor de los charrúas. Cfr. 89.

74 En otra oportunidad Josefina cita un parte de Garzón donde se percibe en los planes del gobierno una "traición" a los charrúas: "Ya no nos queda otra cosa que hacer que dar el paso sobre los salvajes. Este creo que es más fácil pues ya tengo tomadas algunas medidas, y las que tomaré, tan luego como me incorpore a usted. Los salvajes están como avispados, han sido avisados de que el gobierno los mandaba a destruir, yo los he persuadido de lo contrario, y han quedado algo satisfechos; $y$, a su tiempo, tendrán su merecido" (58). 
inflexiones de las frases que descubren la interioridad del que escribe, como en las palabras con que Bernabé alude a María Luisa: "lo hace con una fórmula que, por el diminutivo, parece muy tierna pero que termina impresionándome como morbosa y aniñada" (84). Conjetura las causas del estado de ánimo de Bernabé cuando en una carta se queja del mal tiempo, falta de caballos y otros inconvenientes, lo imagina lejos de su hijo recién nacido y de su "bellísima esposa". Desmenuza la sintaxis y recrea al mismo tiempo el impacto que hubiera podido causar en el espíritu de don Frutos la lectura del parte que José María Navajas le envió anunciando la muerte de Bernabé (121). En este punto emerge una lectura de los "hechos históricos" desde el excedente provisto por los valores literarios, distante de los mandatos disciplinarios de la historiografía.

La mirada de Josefina indaga otra dimensión de los personajes, su conciencia. Suele yuxtaponer -y contraponer- la representación exterior de los hechos con un acercamiento al interior, incluso mediante el acercamiento espacial de la focalización, como en la escena en que don Frutos incita al pueblo a festejar la supuesta llegada de Bernabé desde su ventana, mientras en el interior Manuelita solloza por la muerte de su esposo. Del mismo modo, cuando describe el retrato que ella pintó de Bernabé procura despojarlo de sus señas más visibles "intentando liberar a Bernabé de esas patillas y de esa barba y bigotes que, según dicen, cuidaba con maniático esmero" para "entrever un rostro aniñado e insulso" (33).

Esta novela inaugural de la serie, incluye un rito que se va a reiterar en las otras: la apertura del archivo para interpelarlo, contradecirlo, rescribirlo desde los "ojos de Andrómaca" de Josefina. En este caso, el "Archivo Narbondo" ostenta todas las marcas del poder: postula la versión -escrita y pública- de la versión hegemónica sobre la 
"necesidad histórica" del exterminio por parte de los "padres fundadores".

Estos diferentes usos de los documentos provocan un cruce continuo de opiniones que dan al texto su carácter dialógico. La novela privilegia la "conversación" como modo de acercarse a la historia. En Josefina hay todo un trabajo y un especial interés en lograr las condiciones adecuadas para sostener una conversación y sortear las disputas que sólo enfrentan opiniones irreconciliables. Desliza quejas sobre el modo en que su padre y su marido suscitan "disputas" con ella -a las que suele calificar con expresiones militares como "(Narbondo) se atricheró en el bando de mi padre", "la ofensiva de Juan Pedro", "Narbondo aceptó con su habitual elegancia la derrota pero cuidó su retirada". En cambio prefiere utilizar el término "conversación" para referirse a sus charlas con Gabiano, cuidadosa de las estrategias para no quebrar un intercambio productivo ("De a poco, él hablando y yo asintiendo, se fue tranquilizando. Con prudencia, procuré que mis disculpas evitasen que la conversación se desviase. La difícil humildad fue la clave de mi éxito (...) me di cuenta que, si no nos interrumpían, la charla estaba definitivamente encauzada", 59).

El tema del juicio -otro de los debates centrales de la posdictadura- recibe un tratamiento complejo en la novela. Josefina, acorde a lo que en una entrevista expresó T. de Mattos, se niega a dar una sentencia: "No voy nunca a ser juez" (58). Su principal actividad, sin embargo, nos coloca en los preliminares de un juicio, en una posición cercana al fiscal encargado de la recolección de documentos, la conversación con los testigos, la verificación de las informaciones por medio de fuentes confiables, las reflexiones en torno a los argumentos de la defensa y la acusación. Por otro lado, si Josefina se niega a asumir por sí sola el papel de la justicia, la novela no descarta la obligación colectiva de juzgar a través de las instituciones correspondientes, por el contrario, 
el editor MMR instala el tema a partir del juicio de Nuremberg: "(...) los perpetradores de los crímenes que hoy repudiamos y cuyo castigo tanto nos congratula" (25).

\subsection{Las femeniles disquisiciones. A modo de reflexión final}

Si la denuncia de los sistemas de opresión imperantes en los países de América Latina ha sido tema recurrente de su literatura, aquí me interesa detenerme no tanto en ella como en el tratamiento y las significaciones dadas por esta novela.

En ella se advierte la presencia de un campo semántico de raigambre cristiana, expresado principalmente a través de la duda, el juicio, la culpa, la responsabilidad, y que aporta sobre todo una perspectiva ética. En un artículo Tomás de Mattos se ha definido como un "cristiano de izquierda". ${ }^{75}$ Es desde este filtro cristiano que De Mattos aborda y reconfigura la posdictadura apuntando a determinados valores coincidentes o complementarios con aquellos que provienen de los debates de la posmodernidad: la preeminencia de los valores éticos, el rechazo del "juicio", la comprensión y la tolerancia, la duda.

En una entrevista con Rosario Peyrou, Tomás de Mattos se distancia de las propuestas de Alejo Carpentier, si bien comparte varias ideas, disiente en cuanto al "compromiso político": "Pero entiendo de forma muy diferente lo del "compromiso político". Yo lo cambiaría por "compromiso ético" (...) Yo, como escritor, no puedo decir que soy juez de la historia. Me parece que la realidad es muy compleja y el escritor debe tener mucha humildad. Se terminó el tiempo de los grandes

75 Cfr. "La empresa y las identidades uruguayas", en: Identidad uruguaya ¿mito, crisis o afirmación?, op. cit., p.135. 
pontífices que decían dónde estaba el bien y dónde el mal e impregnaban su mundo narrativo con ideología". ${ }^{76}$

¿Bernabé, Bernabé! incluye un cuestionamiento a las certezas unívocas de la historiografía, apela a la "conversación" para dirimir los conflictos y posturas enfrentadas, recupera voces disímiles. Confía en la narración y sus posibilidades dialógicas como una apertura a las alteridades de todo tipo, y como una vía -quizás- para superar la violencia imperante durante las décadas de los sesenta y setenta, un intento por reformular las relaciones y conflictos entre los diversos sectores sociales a fin de escapar a la lógica de la violencia. En este sentido Josefina insiste en el tema de la duda: "las dudas y el temor de perder la ecuanimidad", la misma duda que el editor propone como freno a los "caminos que desembocan rectamente en la atrocidad" (25). Podemos pensar la duda como una alternativa a las ideologías fuertes.

En este marco, la tolerancia, la conversación, la duda, el "plácido y desencantado período final" desde el cual escribe Josefina, cobran otra dimensión, una dimensión crítica hacia las pasadas ideologías fuertes y un lugar alternativo para reformular los pactos sociales. ${ }^{n}$

76 Cfr. "Con Tomás de Mattos. 'No quiero ser juez de la historia' ", El País Cultural, Año II, No. 144, 7 de agosto de 1992.

77 Ana Inés Larre Borges, Rosario Peyrou y Hugo Achugar apuntan, de uno u otro modo, estas características. Peyrou hace hincapié en el acto de "comprender" y la importancia que alcanza la duda en la novela; Larre Borges señala también la duda como el método privilegiado que se articula en la técnica del contrapunto y Achugar -en abierta polémica con Lockhart- destaca el "derecho a opinar y disentir que tiene todo ser humano" en contra de los "catones y los depositarios de la verdad". Cfr.: Achugar, H., "Como el Uruguay no hay, ¡Bernabé, Bernabé! Y el referéndum, Cuadernos de Marcha, Tercer época, año IV, $\mathrm{n}^{\circ} .40,1989$ y "El referéndum no leído y otros problemas de hermenéutica bifocal", en Cuadernos de Marcha, Tercer Época, año. IV, $\mathrm{n}^{\circ} .42$, 1989; Larre Borges, Ana Inés, "Los ojos de Andrómaca", Brecha, año IV, nº 166, 27 enero 1989; Lockhardt, Washington, ¡Bernabé, Bernabé! leído con lentes bifocales", en Cuadernos de Marcha, Tercer Época, año IV, ${ }^{\circ} .41$, 1989, “iBernabé... y su antiética”, Cuadernos de Marcha, Tercer Época, año IV, no. 43, 1989, "La historia desvencijada en ¡Bernabé...! , Brecha, año IV, n. 167, 3 febrero 1989; Peyrou, Rosario, "Los espejos de la historia", El Pais Cultural, 17 febrero, 1989. 


\subsection{Apéndice}

Doce años después de la primera edición, Tomás de Mattos reescribió ¡Bernabé, Bernabé! (2000). Sobre esta segunda versión que agrega unas setenta páginas y modifica la totalidad de la novela, me interesan dos cuestiones. En primer lugar los cambios introducidos en diferentes niveles de la novela, para luego indagar sobre los motivos que impulsaron esta nueva versión, ciertamente importantes para aceptar el riesgo de ampliar una novela signada por el éxito.

En el acápite que preside la nueva edición, Tomás de Mattos nos informa sobre la publicación de nuevas investigaciones llevadas a cabo por Eduardo Acosta y Lara que iluminan zonas antes desconocidas de la guerra de los charrúas, razón suficiente -a juicio del autor- para corregir su texto atento a los descubrimientos.

Los nuevos datos triplican el ataque a los charrúas. No hubo una sola matanza en Salsipuedes, sino tres ataques y emboscadas sucesivas en Paso del Sauce, la Cueva del Tigre y Salsipuedes. Esta novedad no modifica sustancialmente el valor del exterminio, pero sí ahonda el carácter sistemático y premeditado por parte del poder.

Por otra parte, la empresa ahora no es obra sólo de orientales, la presencia de Lavalle y de Flores, con soldados argentinos y brasileños, convierte a la celada en un anticipo de la guerra de la Triple Alianza. Otro momento de la historia que se inserta en el mapa de las violencias articulado por la novela (y que, como veremos, varias de las novelas del corpus aquí elegido lo incluyen). También en este caso se trata más de ahondar y expandir que de introducir eventos que trastornen la economía narrativa. 
Si éstas son las principales novedades, Tomás de Mattos no dejó de aprovechar la ocasión para reescribir, ahora en detalles mínimos, la entera novela. Giros de su prosa, el cambio de algún adjetivo, la tachadura de lo que parece sobrar, algunos matices apenas diferentes en sus personajes o gestos, las reflexiones de Josefina, van haciendo de ! Bernebé, Bernabé! una novela diversa desde el detalle. En el cotejo de ambas versiones, más de una vez, me he preguntado si su autor no ha caído en la tentación de ceñir y ajustar ciertos significados que en su primera versión quedaban más librados a la interpretación personal del lector.

La segunda cuestión que me interesa se refiere al pacto de lectura, problema que trabajaré más adelante, pero que ahora no puedo evitar, al menos, mencionar. La reescritura, motivada por un cambio en los documentos históricos, está señalando con insistencia la estrecha relación que la ficción sostiene con el discurso historiográfico, el cual aparece como sostén y garantía de la "verdad" ficcional. 


\section{LAS IDENTIDADES OLVIDADAS. LA FRAGATA DE LAS MÁSCARAS DE TOMÁS DE MATTOS}

La fragata de las máscaras (1996) es una reescritura de Benito Cereno de Herman Melville. ${ }^{78}$ Podemos comenzar, entonces, analizando los cambios que el texto de De Mattos impone a la versión de la nouvelle, para luego plantear los alcances y las significaciones que adquiere la operación de reescritura.

Benito Cereno (1856) cuenta un motín de negros en la fragata Santo Domingo, cuyo capitán da nombre al relato. Pero no se nos narra el motín sino el abordaje de la fragata por el norteamericano Amasa Delano (el protagonista), comandante del Bachelor's Delight quien intenta colaborar con lo que cree es una fragata que sólo ha sufrido numerosos percances. El interés del texto radica en el punto de vista escogido, el de Amasa Delano. Este personaje no percibe los innumerables signos reveladores de los problemas existentes en el mando de ese barco y el lector -guiado por el foco puesto en Delano- sólo hacia el final se entera, junto con su protagonista, que ha acaecido un motín.

Los tropiezos e irregularidades entrevistos por Delano durante las horas que pasa en la fragata configuran el primer enigma propuesto al lector y este "nudo" se desata con un súbito giro: a punto de abandonar la fragata, Delano salta a su ballenera y detrás lo sigue el imprevisto salto de Benito, poniendo al descubierto el motín. El relato continúa con la victoria de Delano sobre los amotinados, el posterior viaje a Lima y el juicio de los culpables. En las últimas líneas, sin embargo, un final ambiguo y abierto invita a otra lectura: el cabecilla del motín, el negro Babo, ha sido ajusticiado y su cabeza puesta en el piquete desafía aún a

78 Las citas corresponden a la siguiente edición: Tomás de Mattos, La fragata de las máscaras, Montevideo, Alfaguara. Ediciones de la banda Oriental, 1996. 
los blancos, mirando hacia la iglesia donde ha sido enterrado uno de sus jefes y donde pronto será enterrado el otro. Veamos la cita en la cual sorpresivamente se le atribuye a Babo el carácter de "jefe", invirtiendo el punto de vista de Delano:

"Unos meses después, arrastrado al patíbulo de la cola de un mulo, el negro halló un silencio final. Su cuerpo fue reducido a cenizas; pero durante muchos días, la cabeza, esa colmena de argucias, clavada en la estaca de la plaza, desafió, indoblegable, la mirada de los blancos. Más allá de la plaza, sus ojos parecían mirar hacia la iglesia de San Bartolomé, en cuya cripta descansaban entonces, y descansan hoy, los recuperados huesos de Aranda; y, más allá del puente del Rimac, hacia el monasterio del Monte Agonía, donde tres meses después de ser licenciado por el Tribunal, Benito Cereno, llevado en un ataúd, siguió, efectivamente, a su jefe" (82). ${ }^{79}$

¿Qué personajes, acciones y procedimientos narrativos interesan a la relectura que hace La fragata de las máscaras de Benito Cereno? ¿qué cambia, agrega, omite, desplaza o amplía?

\section{Las miradas y las voces}

En primer lugar cambia el punto de vista desde donde se narra. La nouvelle de Melville tiene un narrador en tercera persona que focaliza en Amasa Delano, cuya visión de los hechos en la fragata amotinada es un yerro constante. Esta visón equivocada parte de una personalidad, la de Amasa, definida por un "bondadoso carácter y extraordinariamente crédula, y nada inclinada, salvo ante un estímulo extraño y repetido, y aún entonces difícilmente, a ceder ante sentimientos de alarma que de

79 Todas las citas corresponden a la siguiente edición: Melville, Herman, Benito Cereno, Montevideo, Ediciones de la Banda oriental, 1990, con prólogo de Tomás de Mattos. 
algún modo implicaran la suposición de que los hombres actuaban con malignidad" (9). Sin embargo, de un modo subrepticio y progresivo, esta afirmación se desmiente. Por un lado, la mirada de Delano se articula como una visión "desde arriba", desde el "palco" -"su mirada, que descendía continuamente, como desde un palco a la platea, hacia la extraña multitud que tenía delante y por debajo..." (42). Otra escena parodia la mirada desde el balcón: Delano sube al "balconcillo" para ver mejor pero la balaustrada cede y el capitán casi cae al mar (38).

Por otro, en su concepción sobre los negros y mestizos esta mirada "desde arriba" pone en evidencia una ingenua ideología etnocéntrica, en cuanto los considera naturalmente sumisos, y por eso no puede descubrir el motín: "esa docilidad que nace del contento de un espíritu limitado y sin aspiraciones, así como esa disposición a un ciego afecto que a veces distingue a los seres indiscutiblemente inferiores" (47). Estos prejuicios se quiebran no sólo porque al final la realidad del motín se hace clara a pesar de la ceguera de Delano sino, y de un modo más contundente, porque el final desplaza abruptamente la mirada hacia los ojos de Babo, quien a pesar de estar muerto se constituye en el "jefe" obedecido por sus antiguos capitanes. El triunfo del jefe amotinado cubre de sospecha la primera lectura e invita a revisarla. Podríamos decir que ese es el punto de partida, el desafío inicial de De Mattos para su novela.

La fragata de las máscaras comienza con un replanteo del punto de vista, que condensa una de sus mayores significaciones. Si la mirada de Delano se ejercía desde "arriba", desde el balcón, La Fragata... la invierte; focaliza desde "abajo", retoma y continúa la mirada de Babo que cierra Benito Cereno. Si Delano parte de una serie de prejuicios etnocéntricos, La fragata .... los invierte al intentar recuperar el punto de vista en los negros. 
Esta extensa novela se estructura en el cruce de voces, puntos de vista, relatos y fuentes. El ficticio editor MMR decide publicar en 1956 los manuscritos de Josefina Péguy de Narbondo, vueltos ya problemáticos en su condición de "originales". El editor encuentra una carta de Josefina dirigida a Melville y dos versiones de su novela: dos gruesos cuadernos de tapa dura enviados por ella a Melville, escritos es inglés, y cinco cuadernos en castellano que dan una versión más extensa con agregados y comentarios de su marido Narbondo. Josefina, a su vez ha utilizado a su discreción las acotaciones de Narbondo para la versión inglesa. MMR elige la versión inglesa -que traduce al castellano- para publicar en La fragata..., ya que encuentra tardíamente los originales en castellano. Si bien la novela contiene uno solo de los manuscritos de Josefina, el otro original opera como una inquietante ausencia. Además, el relato de Josefina fue escrito en colaboración con su tío Gustavo.

También las fuentes se multiplican. Benito Cereno de Melville tiene como fuente, el capítulo XVIII de las Memorias del capitán Amasa Delano: A narrative of Vogages and Travels in the Northern and Southern hemispheres comprising three voyages round the World, toguether with a voyage of survey and discovery in the Pacific Ocean and Oriental Islands, publicadas en Boston en 1817. La fragata de las máscaras no sólo se basa en una reescritura de otra reescritura, la nouvelle de Melville, sino que Josefina añade otra fuente, el relato de su padrino Bonpland de diálogos y comentarios con los participantes en el motín y en los sucesos posteriores. La novela incluye, también, una "Nota preliminar" del ficticio editor MMR, la "carta a Herman Melville" escrita por Josefina, la cita de un fragmento de Melville extraído de Las Encantadas y un "Epílogo. La carta de Lizzie" (enviada a Josefina por la esposa de Melville). A la visión de los negros se añade, como vemos, la voz femenina. 
De este modo el truco del manuscrito hallado y publicado, que procuraba dar veracidad al texto, se convierte en el espacio de cruces de manuscritos, de traducciones, de fuentes diversas que desmienten la idea de un original para autorizar la reescritura continua como un modo de reinterpretar desde el presente los textos de la cultura.

La estatuilla de múltiples rostros que el editor encuentra entre las cosas de Josefina simboliza -en otro registro- esta multiplicidad de miradas: "Apenas he hallado una estatuilla, no sé si auténtica, que parece provenir de la cultura dogona: de un único cuerpo emergen tres caras (el lector ya la habrá visto en la portada de esta edición). ¿Representa al mandinga Babo, al Dogón Dago y al arará Muri procurando dar muy distinto sentido al único destino que los enreda? ¿O alude a los talantes diferentes y a veces antagónicos con los que cada persona suele afrontar la vida, según sean las cambiantes circunstancias?" (16)

La cita pone en claro que no se trata únicamente de articular el punto de vista de los vencidos; la novela varía y diversifica el interior mismo de la voz de los negros a partir de, fundamentalmente, tres personajes que representan no sólo tres culturas diferentes -mandinga, dogón y arará- sino tres perspectiva diversas: la de Babo en tanto jefe de la sublevación, la de Dago en su calidad de curandero y la de Muri como hechicero, indudable rechazo a la homogeneización de las culturas de herencia africana. La diversidad es un principio estructurante que opone y acerca a los personajes, configurando series binarias y ternarias. A la serie Babo, Dago y Muri se opone y complementa la del fraile Tobías, el científico Humboldt y el médico Bonpland. Al perfil católico de Josefina se opone el agnóstico de Gustavo. Los hermanos Abos diseñan dos perspectivas frente al juicio: mientras José es un magistrado, Tobías se niega a juzgar. Pero a su vez el Juez Martínez de Rosas se opone al magistrado José en el mismo juicio. 
La novela aparece atravesada por un impulso que tiende a diversificar las voces, pero también por la posibilidad de conciliarlas a pesar de sus diferencias o, mejor, manteniendo sus diferencias. Dicho de otro modo, los credos, las religiones, las ideologías políticas, las profesiones no siempre impiden -o no deberían siempre impedir- la cooperación en la construcción de América Latina. Una preocupación -por otro lado- de larga data en América Latina, basta pensar en "Nuestra América" de José Martí. En esta línea Josefina atribuye a Bonpland las siguientes reflexiones: "Y su versión fue sesgada por la obsesión que animó y amargó sus últimos años. No sé qué le dolía más: si las vidas absurdamente cercenadas, si las tierras y las libertades arrebatadas, si el extravío de los ideales que caldearon su entusiasta mocedad, si la contumacia con que los habitantes de esta tierra se empecinaban en confundir 'europeidad con civilización y americanidad con barbarie', en vez de converger en construir entre todos "una civilización americana"" (25).

Esta posibilidad de encuentro y cooperación "entre todos" y a pesar de sus desacuerdos, se percibe en las alianzas que la novela establece. La reescritura de Benito Cereno la emprenden Josefina y su tío Gustavo, luego de una discusión -"querella doméstica"- que puso en evidencia los disímiles puntos de vista así como sus credos: "Da la casualidad, Josefina, que tú eres la católica y yo el agnóstico" (30). La amistad de Bonpland con Tobías se plantea a pesar de sus diferencias; "Leuda entre nosotros una afinidad tangible, pese al básico antagonismo de nuestras posturas filosóficas" (48).

Pero se trata sobre todo de volver a contar el motín de Benito Cereno desde el punto de vista de los negros, de continuar el texto de Melville en el punto en que éste quebró la mirada desde el balcón de Delano para sustituirla por la mirada de desafio de la cabeza de Babo. En 
esta decisión subsiste un problema ya clásico en las perspectivas sobre el "otro" y su "voz".

El problema teórico frente a la alteridad ha sido extensamente discutido en las ciencias humanas y, en el campo literario ha suscitado debates en especial frente al testimonio. Uno de los problemas más discutidos radica en la legitimidad de la "apropiación" de la voz del "otro" o en el carácter representativo del letrado frente al informante. ${ }^{80} \mathrm{La}$ fragata de las máscaras si bien no se presenta como un testimonio o novela testimonial, declara la voluntad de articular la voz de los "débiles", la versión de los negros. Lo cual supone en esta novela la ficcionalización de sus voces.

Advertida de los peligros que conlleva la "representación" de los negros, Josefina declara la estratagema de la que se vale y opta por hacer explícito el lugar de apropiación desde el cual habla, por articularlo en tanto "máscara".

La figura de la máscara en Benito Cereno de Melville apunta especialmente a la farsa de Babo para engañar a Delano: "A los ojos del capitán Delano, cuya imaginación volvía a recuperar todo su vigor, había algo tan falso en las maneras del español y en el silencio del criado (...) que cruzó por él como un relámpago la idea de que posiblemente ambos, por algún motivo desconocido, estaban representando, con hechos y palabras, alguna engañosa comedia ante él" (51); "¿No sería que no tenían otra finalidad que la de enmascarar algún proyecto maligno?" (60) y "los negros, no entregados a un desordenado tumulto o a la terrible angustia que parecía haberles inspirado don Benito, sino, liberados ya de

80 Cfr. entre otros: Sklodowska, Elzbieta, "Miguel Barnet: Hacia la poética de la novela testimonial", en Revista de Crítica Literaria latinoamericana, año XIV, 1988, n. 27; y "Testimonio mediatizado: ¿Ventriloquia o heteroglosia? (Barnet/ Montejo; Burgos/ Menchú", en Revista de crítica literaria latinoamericana, año XIX, Lima, 1993, n. 38; Achugar, Hugo, En otras palabras, otras historias, Montevideo, Universidad de la República, 1994. 
su máscara, esgrimiendo hachas y cuchillos, en su salvaje motín de piratas" (64). Sin embargo, la figura de un negro sátiro enmascarado que somete a otra figura enmascarada del escudo de popa parece abrirse a otras alusiones.

En La fragata.. la máscara -cuya mención forma parte del título de la novela- aparece con varios y contrapuestos significados. La máscara como engaño, más que remitirse a una farsa montada para embaucar a un tercero, refiere a la "persona" que aún no ha descubierto o decidido su destino. El proceso de desenmascaramiento, casi como una anagnórisis, atañe a varios personajes, aunque citemos sólo el caso de Babo: "esa lengua y esos ojos todavía vivían porque habían pertenecido a un ser que se había dejado quemar hasta el cerno y desembarazado de cortezas y hojarascas" (383) y "un hombre que ya había purgado sus pecados y se había aligerado de toda máscara" (194). "Las máscaras de la muerte", título del capítulo cuarto, parecen aludir borgeanamente al encuentro del muerto con su destino final.

En franca oposición con la concepción anterior, la máscara es también un lugar desde el cual es posible actuar, transformar la realidad o proponer una "verdad", sin mentiras o a pesar de ellas. Éste parece ser el significado de la cita de Moby Dick del epígrafe inicial la novela:

"Todos los objetos visibles, amigo, no son sino máscaras de cartón. Pero en cada acontecimiento, en el acto vivo, en la acción resuelta, algo desconocido pero siempre razonable, proyecta sus rasgos tras la máscara que no razona. ¡Y si el hombre quiere golpear, ha de golpear sobre la máscara! ¿Cómo puede salir el prisionero, si no atraviesa el muro?" (11).

En este carril se comprenden fundamentalmente dos acontecimientos: el baile ritual de Muri que pone en marcha el motín, y el coronamiento de Babo como jefe. En ambos casos los personajes dejan 
traslucir que no interesa demasiado si los dioses efectivamente se hicieron presentes en estos actos rituales, sino el uso que se haga de ellos, la apropiación de las máscaras de los dioses con fines libertarios. Aquí lo que interesa es, más que la máscara, su uso.

En tercer lugar, la máscara es un procedimiento ficcional para articular las voces de los personajes en sus diversidades -femenina, indígena, negra, etc.- poniendo en claro ese carácter ficcional, tal como se desprende de la afirmación de Josefina: "cuando tuve oportunidad de decirle toda la verdad y nada más que la verdad (y usted sabe que me apropié de varias de sus mentiras y añadí muchas más) lo hice a través de una u otra máscara" (387).

La máscara desmiente una apropiación que quiera fingirse invisible pero, por otro lado, permite expresar ficcionalmente ese otro lugar de la alteridad. Aquí nos sirve la categoría de "intelectual solidario" de Achugar para interpretar esta apropiación de las voces alternas. E1 editor aclara -y con ello desarma- la trampa del punto de vista: "Llegado este punto, sólo me resta anticipar que llama la atención el afanoso esfuerzo por africanizar las máscaras negras que, junto a otras de sangre cuarterona, entrecruzan sus discursos o directamente encaran al propio Melville. A pesar de que, sin duda, no discurre en las disquisiciones de los esclavos un pensamiento auténticamente africano y sólo pulsa, en su trasfondo, la solidaria angustia que acosa a una única mente blanca que se esconde tras esos personajes, también es perceptible un cierto conocimiento, a veces vago, a veces pormenorizado, de los ritos que se tributa a los orixás" (15). La idea de "solidaridad" con los débiles es una elección a la cual apelan tanto Josefina como Tobías.

Estas múltiples máscaras evalúan cada acción importante creando un estado de deliberación permanente, de preguntas, conjeturas, apreciaciones, debates, disputas. En el prólogo a Benito Cereno Tomás 
de Mattos comenta el juicio crítico de Borges sobre esta novela: "Hay quien ha sugerido que Herman Melville se propuso la escritura de un texto deliberadamente inexplicable que fuera un símbolo cabal de este mundo, también inexplicable" (5). Esta indeterminabilidad del texto se convierte en una invitación a una reescritura que no lo cierre en una versión unívoca. De Mattos sustituye la inexplicabilidad del texto por una multiplicidad de aproximaciones a los hechos acaecidos: "la novela es, como el mundo, muy esquiva a una explicación unívoca" (7).

La factura de La fragata de las máscaras incluye, dijimos, varias voces. Veamos cada una.

En La fragata... Bonpland aparece a la vez como par y figura contrapuesta a Humboldt. Ambos son representantes del iluminismo, de la ciencia, de la mirada europea que interroga a América. Como un altorrelieve, el esclavismo contrasta y convive con el siglo de las luces y sus "progresos".

Pero las diferencias entre ambos son perceptibles, como si Bonpland representara el proceso de crítica a su compañero y jefe de expedición. La narración, tanto en el caso de Bonpland como en el de Tobías, se coloca en boca de personajes de menor rango y ésto no parece casual, de algún modo critican a sus superiores o se distancian de ellos. En el primer capítulo, "El fraile insomne", (relato de Bonpland a Melville) se exponen dos modos de acercamiento a los negros e indígenas, dos diferentes miradas. En la primer escena se describe la relación entre indígenas y europeos a partir de la burla, la máscara y el rencor de los primeros ante el trato desaprensivo de Humboldt quien pone en juego su superioridad. La aproximación de Bonpland va a desanudar ese trato esquivo hasta conducirlo a una recíproca confianza, cuyo resultado final es la revelación del tesoro oculto de los antepasados incas. 
Bonpland percibe la realidad desde sus sentidos, en oposición a la "razón" esgrimida por Humboldt. Huele los olores a pescado y a comidas del puerto de Huanchaco, siente su aire húmedo, se preocupa obsesivamente por su cuerpo y observa el cuerpo de los demás: "Arde el enredijo de mis tripas y tengo entumecidas mis asentaderas"; "Algo, o todo, ha desvastado mis entrañas" (39). Observa también el carácter de los indígenas con quienes Humboldt negocia el precio de la comida: "el trato sumiso y servicial, el designio sostenido y calculado de extraernos, por cualquier vía, el mejor rendimiento (...) un mal escondido rencor ancestral; que es tanto más hondo cuanto más exacerban, con palabras, sonrisas o reverencia, el obsequioso reconocimiento de la superioridad de nuestra raza y de la cultura de la que provenimos" (38). Humboldt considera natural la jerarquía: "Como realmente se considera superior a casi todo humano...esa obsecuencia generalizada le parece justa y necesaria" (39). Con otra personalidad, con rasgos más equívocos, Delano también manifiesta el "desprecio que siente por los negros" (47) a través de un carácter en el que "la bondad y la soberbia se confunden" (47).

La percepción de América desde los sentidos, desde el cuerpo, desde "abajo" llega a un punto culminante cuando Bonpland prueba el guano con su paladar. El guano como síntesis de los contrastes de América Latina, como expresión de la convivencia de las ruinas, pérdidas y fracasos de su historia con sus posibilidades de fecundación. La prueba, el catado del guano oficia como un rito de iniciación al conocimiento de estas tierras. Inmediatamente en el primer apunte, "El jardín reservado", el hijo del cacique Astortilco le muestra a Bonpland las ruinas del palacio de su antepasado, el Inca Atahualpa y le revela el oculto tesoro como prueba de mutuo respeto: "Como si definitivamente nos hubiera entregado su confianza" (67). Este cambio va más allá y pone en juego 
una serie de cambios similares en toda la novela. Es el acto de sacarse la máscara para revelar un secreto.

Tobías Infellez configura una de las voces más importantes de la novela. Es un fraile díscolo del monasterio del Monte Agonía. Aparece atravesado por un proceso secularizante, que Bonpland define: "sus modales parecen, por viriles y seculares, más que los de un sacerdote, los de un seglar profundamente enamorado del mundo, pese a sus miserias (...) recita de memoria los versículos de la Biblia, como si fuera un luterano o un calvinista; pero los aplica a la vida como si fuera un librepensador" (53). Su origen "bastardo, adulterino y cuarterón" ya lo coloca como representante del "mestizaje" latinoamericano que asume al ocuparse de los negros, indios y delincuentes (75).

Su relación con Benito Cereno, de quien se ocupa en el convento y a quien debe calmar su alma, corre por los carriles del diálogo ya que cuando decide confesarse no lo hace con él sino con fray Angélico, su prior. Lo cual si bien es una necesidad del relato pues la confesión impone el silencio, indica también una relación más secular entre ambos. Finalmente Tobías accede al "secreto" a través del relato que le hace Dago: "Al cabo de los días accedí, sin confesión alguna, al secreto que tanto turbó los últimos días de don Benito" (223).

Tobías representa una imagen bastante peculiar de la voz del cristianismo en América Latina: en conflicto permanente con el Santo Oficio; ha participado en la rebelión de Túpac Amaru y acusó públicamente el ajusticiamiento de Babo; elige colocarse del lado de "los débiles"; tiene inclinaciones hacia el arte; lee y articula diversos credos religiosos combinándolos con bastante libertad. ${ }^{81}$ Pero también se dedica a evaluar pérdidas y fracasos (Túpac Amaru y el motín de Babo)

81 Podríamos decir que Tobías se anticipa, en parte, a los reclamos de "aggiornamiento" del Concilio Vaticano II y a las tendencias renovadoras de la Iglesia tercermundista de América Latina. 
indagando si hay y cuáles son las posibilidades inscriptas en estos fracasos.

Las voces de los negros están diversificadas en tres puntos de vista para desarticular una aproximación homogénea.

Dago es un negro dogón que ha aprendido una mezcla de medicina y curanderismo (85) al servicio del médico Pedro Ortiguera y cuida el jardín de hierbas que ha levantado en el convento. Su figura es paralela, dentro de las culturas negras, a la imagen del "científico" y evalúa con una gran dosis de escepticismo los rituales de Muri. Introduce constantemente un perfil crítico frente a los usos de la religión y a los manejos del poder. Guía su vida el principio de la "supervivencia".

Muri, el hechicero del grupo, ha recibido la sabiduría y los rituales africanos de su madre. Dago y Muri se contraponen continuamente en su apreciación de los hechos: mientras Muri cree en la actuación de los dioses en el motín, Dago lo pone seriamente en duda ("Como siempre, curandero y hechicero discrepamos en la interpretación y valoración de los hechos que acababan de ocurrir", 261). Dago interpreta el motín desde una posición crítica y escéptica, descree de la victoria y de la posibilidad de alcanzar la libertad, pues sólo ve un cambio de personas en el mismo sistema de dominación. Finalmente es quien pone más reparos a la probabilidad de llegar al Senegal, una imposible utopía o una treta de Babo para distraer a los negros. No obstante ambos van a colaborar en el motín y también ambos van a sufrir un cambio a partir de la rebelión.

La voz de los negros, si bien incluye ritos y frases en yoruba, dista de ser una perspectiva folklorizante. Por el contrario hay en la novela una voluntad de "universalizar" estos personajes, perceptible sobre todo en su capacidad para evaluar sus saberes particulares con un perfil crítico, 
poner constantemente en duda sus acciones y alcanzar un diálogo fluido con otras culturas.

Benito Cereno es uno de los personajes más esquivos de la novela, pues no se desentraña claramente su participación en el motín, ni su relación con los negros. En parte, el texto de Melville autoriza esta interpretación. Se opone francamente a su socio Aranda porque no le reveló de entrada su intención de traficar con negros, si bien finalmente acepta ese comercio ("Conocidos los desvaríos liberales del chileno no le fue franco, pero ya entonces abrigaba la idea de dedicarse al tráfico de esclavos", 88). Su relación con los negros dista de la de su socio: "don Benito se jactó de que todos los esclavos del mendocino no tardaron en trabar con él un vínculo mucho más fluido y armonioso que el que mantenian con su propio amo" (89). Estos datos y la defensa que Benito hace de Dago, llevan a Tobías a suponer su participación en una revuelta contra Aranda: "don Benito no era la afligida víctima que fingía ser, sino el cómplice o hasta el coautor de una conjura que luego Babo había desviado hacia el motín" (90). Muri señala en una ocasión el interés de Benito por sus rituales: "como poco a poco lo iba haciendo el infortunado Niño, se interesen por adquirir nuestra sabiduría" (157) y "Su embeleso era tan transparente como inexplicable, porque en su historia personal nada había que lo obligara o lo moviera a sentir casi como suyos esos ritos que cada vez le resultaban más inteligibles" (228)

Su punto de vista no se articula desde arriba, en ciertas ocasiones se acerca a las opiniones de los negros e, incluso, se arriesga a responder por Babo: "Quizá Babo respondería esa misma pregunta diciendo que ellos también eran, aunque no para vender, nada más que mercadería; mercadería para usar" (105)

Benito Cereno aparece en la nouvelle de Melville como un personaje pusilánime, sin capacidad de mando, pero tampoco se define 
completamente su perfil. La fragata... va un poco más allá aunque no descubre por completo sus secretos. El texto parece colocarlo del lado de los negros, conociendo y apoyando su huida en la balandra. En momentos de su muerte aparecen ciertos indicios que lo acercan a la figura de Cristo, desde un lado opuesto al de Babo. Dice Tobías: "Vi, entonces, en el costado izquierdo, muy cerca del lugar donde Cristo debió recibir el lanzazo, una alargada mancha rosácea" (173), símbolo quizás, de su redención final provocada por su postrer apoyo los negros.

Finalmente La fragata... introduce las voces femeninas de Josefina y Elizabeth Melville. Más adelante analizamos la importancia de Josefina y el lugar desde donde reescribe la novela.

El punto de vista de Narbondo -escamoteado y apenas sugeridoes el de un abogado y su aporte está relacionado con su profesión. Dos datos interesan. Por un lado es un abogado liberal que lucha por la instauración de ciertos derechos, adelantándose incluso a su época. El editor describe los papeles que encuentra de él: "un puñado de desatendidos anteproyectos que procuraron liberalizar, demasiado precozmente, ciertos institutos del Derecho de Familia (divorcio, equiparación de la filiación legítima y natural, protección de la concubina, reducción de la cuantía de las legítimas rigurosas, etcétera)" (13). Por otro lado, Narbondo tiene en su escritorio -donde ejerce el Derecho, la Ley- la perspectiva de la locura en los cuadros de Géricault: "hasta su muerte, diez monomaníacos ensimismados, colgados por encima de un alto lambriz de teca, rodearon desde las cuatro paredes las largas esperas de los clientes de mi marido (...) Pero el cuadro predilecto de Juan Pedro era (...) el único que decoraba su despacho: La balsa de la Medusa. -Si la vida, querida mía, es una zozobra continua, necesito siempre ese puñado de compañeros que, todavía sin la seguridad de ser advertidos, avistan por lo menos una posibilidad de salvación" (389). 
Narbondo contribuye a dibujar el perfil de Dago marcado por el deseo de salvación individual, por la necesidad de sobrevivir; limitado a un instinto natural carente de una dimensión religiosa. Dice MMR: "El marido fue decisivo, a lo largo de casi toda la obra, en la conformación psicológica de Dago, aunque dudo que estuviera de acuerdo con la actitud asumida por el personaje hacia el final" (15). Es decir, Narbondo configura la personalidad de Dago, podemos suponer, en su visión crítica y descreída de los sucesos del motín y por ello no coincidiría con el giro final de arrepentimiento y transformación de Dago.

Además, Josefina tuvo en cuenta las sugerencias de Narbondo para escribir algunos capítulos, el tercero y la segunda mitad del cuarto, centrados -desde diversas ópticas- en el problema del juicio y la justicia. En el tercero, "El reino de la indignidad", José Abos, otro abogado, cuestiona los alcances y los modos autoritarios del juez. En la segunda parte del siguiente capítulo se invierte la escena mediante la participación de Tobías en los momentos previos a la ejecución de los negros, medida que responde más que al castigo, al deseo de "doblegar al negro, aunque no para lastimarlo, sino para restañarle el corazón" (179).

De este modo, Narbondo configura la mirada reprobatoria de José Abos ante el castigo implacable del juez, y la iracunda censura de Tobías frente al juicio que culpó a Babo. Se corre de la escena del juicio para articular una perspectiva crítica.

La estructura de La fragata... a partir del cruce de voces resulta uno de los estratos más significativos de la novela, allí se anudan a un tiempo los registros de las diferencias, la posibilidad de la máscara y la metáfora del "nosotros". 


\section{Ecce niger}

La fragata de las máscaras coloca en el centro de su trama a Babo y lo convierte en un Cristo negro, sobre todo a través de las miradas de Josefina y de fray Tobías. La carga simbólica de una lucha por la liberación del hombre hasta afrontar la muerte en la crucifixión cooperan para dar a Babo significaciones de un Cristo negro. Josefina es la primera que realiza esta asociación a partir de la lectura de Benito Cereno. Y luego, al iniciarse el juicio, José Abos lo recibe con las palabras "Ecce niger".

La perspectiva desde la que ingresa el cristianismo en $L a$ fragata... puede ser entendida a partir de la idea de "secularización" que Vattimo analiza, ya que ella tiene como una de sus marcas más características el abandono de la propuestas de los existencialistas cristianos, quienes habían cargado las tintas en la distancia de Dios frente al hombre, en la concepción de una divinidad capaz de dar cuenta del absurdo existencial y que por ello mismo revestía a Dios de rasgos irracionales. ${ }^{82}$ Para Vattimo este dios irracional (supervivencia del dios vengativo $\mathrm{y}$ violento de las "religiones naturales") implica la servidumbre del hombre frente a una divinidad distante e incomprensible, idea que en más de una ocasión ha servido para justificar políticas autoritarias. Por el contrario, la secularización se asentaría en una recuperación del cristianismo fundada en la máxima "no os llamo ya siervos sino amigos". Se trueca la imagen del dios que impone justicia por el valor de la "caritas".

82 Gianni Vattimo, Creer que se cree, Bs. As. Paidós, 1996. En cuanto a la idea de "secularización" expuesta en este texto, dejo de lado las articulaciones que Vattimo hace con las posturas filosóficas de Nietzsche y Heidegger en su configuración de un "pensamiento débil". De un modo general, me interesa el cambio que la secularización opera en la concepción del cristianismo, en la imagen de Dios y en la relación con la historia y lo mundano. 
La secularización implica, además, una mayor atención a las condiciones de existencia en el mundo, a los conflictos de la historia, a las necesidades concretas de salvación a partir del valor de la caridad. La secularización tendría su momento de inicio en la encarnación -kenosisde Cristo, en cuanto implica el primer paso de acercamiento de Dios al hombre que pone fin al dios distante. A ello se añade la idea de que "la revelación continua": el mensaje de Cristo no es algo ya dado e inmovilizado en el dogma, sino una salvación en curso. Para ello se sigue el modelo del mismo Cristo, quien tradujo la letra, frecuentemente violenta, de los preceptos y las profecías a términos conformes con el supremo mandamiento del amor. Esta "hermeneusis" o interpretación implica releer los "signos de los tiempos", recuperar la propia historicidad, articular el mensaje divino con la historia secular; en este sentido se acercaría al "libre examen" de las escrituras propuesto por Lutero.

Babo adquiere la dimensión de Cristo -de un Cristo secularizadocuando decide la salvación de su gente, la posibilidad de alcanzar la libertad. Esta resolución implica la asunción del "amor al prójimo", la caritas, en contra de un amor egoísta. ${ }^{83}$

En primer lugar Babo, al amotinarse, abandona su puesto de dominio sobre los esclavos. Como mayoral de la carga, tenía el poder de mandar sobre los negros y lo hacía sin ahorrar castigos: "Y para conservar esa magra cuota de poder, cada vez que debió optar entre sus amos y la carga, jamás vaciló en actuar según el interés de los blancos" (230). Ésta expresión de dominio y opresión por parte de Babo es importante como

83 La teología cristiana ha distinguido entre el amor benevolientae y amor concupiscentiae que se traducen como amor desinteresado y amor interesado. Mientras el segundo aparece como "egoísta", el primero se define "como exaltación o estima desinteresada del otro" (117) que incluye "una universal voluntad salvífica", Cfr. Sacramentum Mundi, Tomo I, pp. 114 a 138. 
punto inicial para marcar el cambio que significa asumir la tarea de liberarlos de la esclavitud.

Su decisión de convertirse en jefe del motín despierta en el ritual negro iniciado por el babalocha Muri poco después de zarpar. Allí se expone la capacidad liberadora de las religiones afroamericanas.

El motín comienza con el baile "wa-ni-ilé-ere" que significa -según la novela- en yoruba "participar en las convulsiones de la casa de las imágenes" (235). De todos modos, esta capacidad liberadora no reside necesariamente en la religión, sino en el uso que se haga de ella.

Las creencias de los negros son abordadas desde diversas perspectivas. Muri oficia de sacerdote y convoca a los dioses, aun así inicia el ritual a partir de la máscara, finge la posesión de los dioses como vía para que se hagan presentes: "No le recrimine que esa noche, como tantas otras, haya terminado fingiendo que Eléggua lo poseía (...) Fingir, obligado por las circunstancias, es un insoslayable deber ritual" (233). Dago lo contempla incrédulo e interpreta la aceptación de Babo de los dioses negros como un uso político deliberado. Las perspectivas de los mismos negros sobre su religión se oponen: "Pero mientras Muri supuso que allí afloraba, aunque todavía Babo no lo reconociera, una sagrada vocación, Dago sólo vio el signo precoz de lo que luego sería un radical cambio de comportamiento, motivado por meras razones estratégicas. El mandinga se estaría preguntando qué le impedía servirse, como tantos otros, y para fines que consideraba incomparablemente más altos, de la salvaje religiosidad de su gente" (229).

Esta curiosa presentación de la religiosidad afroamericana dista mucho de una perspectiva que la considere como mera superstición, pero también se separa de quienes, desde una defensa de la negritud, destacan el poder revolucionario como una dimensión inscripta en sus religiones. No obstante, el baile de Muri desata un impulso liberador: "una hembra 
que ha olvidado la esclavitud" (237), y promueve un rito de pasaje y nacimiento "se ha transformado en la hembra que cumple el rito lustral. Se lava el rostro, los brazos, el busto" (238). Babo se transfigura y adopta la figura de Changó, el dios de la guerra, principio que va a despertar el motín. Pero, insisto, lo que más se destaca en la descripción del baile ritual de Muri, es su duda constante sobre la cooperación de los dioses a los que convoca y sobre la real o fingida transformación de Babo en Changó: "Dudosa es la identidad; inocultable la furiosa sed de justicia" (241).

El rito promueve el nacimiento de Babo como redentor: "Ya he comenzado a ayudarlo para que la crédula masa de infelices que nos rodea comience a verlo como la redención que le regala el mismísimo Changó", dice Muri (244). La asunción de Babo como jefe es, sin embargo, sólo el primer paso de su transformación, tal como señala Dago: "Para Muri (Ikú lobi ocha) ya nunca será quien erróneamente fue, pero todavía no es quien está llamado a ser" (258).

El ejercicio de la "caritas" sólo se logra cuando Babo, sabiendo que el barco será asaltado por Delano, propone su último plan: organizar en la balandra una huida hacia la isla Mocha, seleccionando a los niños y los más jóvenes junto con Muri como su jefe. Lo que implicaba quedarse él mismo en la fragata para tener la suficiente autoridad y poder elegir a los que se salvarían. Su cambio implica abandonar el interés individual por el colectivo: "Recién cuando se desembarazó de toda expectativa de sobrevivencia y se propuso que su muerte aparejara la libertad al mayor número posible de compañeros, volvió a recuperar el dominio de sí" (370). En este momento se anudan el "amor al prójimo" con la "salvación" (en una versión secularizada).

Otras de las dimensiones de Cristo que Babo retoma es la idea de redención a partir de la muerte. La crucifixión de Cristo es considerada 
como "un acto mediador de salvación" (23) ${ }^{84}$ Curiosamente esta idea se expresa en la novela no a partir de una referencia al mundo cristiano, sino de una frase en yoruba que Tobías pronuncia - “ilkú lobi ocha!”- cuya traducción es "El muerto parió al santo". Se trata de la idea de un nuevo nacimiento, transformación o redención a partir de la muerte del Cristo Babo. En realidad, la frase yoruba fue pronunciada por primera vez por Muri, cuando explica la transformación de Babo como un parto, "E1 muerto parió al santo" (225), aunque Tobías desconoce este dato y él recuerda la frase de su madre.

La fragata de las máscaras hace de esta frase, en gran medida, nudo de sus historias, pues son varios los personajes que se redimen a partir de la muerte de Babo, entendida como un sacrificio.

En el capítulo cuarto, "Las máscaras de la muerte", luego de que Tobías presencia la muerte de Babo en el cadalso, expone esta concepción. Repudia la muerte de Babo con una iracunda arenga que inicia citando un fragmento del Eclesiastés sobre las violencias contra los oprimidos. Pero si el ajusticiamiento de Babo implica, en principio, la victoria de los opresores, Tobías busca otro camino para recuperar algún sentido positivo en este sacrificio y lo encuentra en la idea de los frutos que nacen de la muerte. Esta concepción prefigura los alcances de la frase en yoruba "E1 muerto parió al santo":

"Porque esta parte de la historia tuvo su propio epílogo; tan noble e imprevisto, que me hubiera gustado que lo hubiera sabido Babo. No para demostrarle que era yo y no él el que tenía razón y que, después de

84 La idea de redención, así como el resto de categorías cristianas que la novela incluye, están atravesadas por un proceso secularizante. En este caso redención no apunta a la resurrección de la carne sino y de un modo más general a la "liberación de la servidumbre" y al predominio de la "verdad, vida, luz, paz, gozo", (Cfr. Sacramentum Mundi, tomo V, p. 765). Por otro lado, la redención presupone una culpa y en los personajes de La fragata... efectivamente la redención los libera de una culpa anterior (nuevamente también la idea de culpa pierde aquí su referencia a la caída y remite a culpas asumidas por cada personaje en su vida). 
todo, el mundo tiene un muy recóndito y dulce sentido; sino para reconfortarlo fraternalmente con la noticia de que su rebeldía, tan iluminada por su audacia e ingenio como ensombrecida por las crueldades que perpetuó, había producido, al menos, unos escasos y desabridos frutos, nacidos después y a causa de su muerte" (200).

La primera transformación, el primer fruto de la muerte de Babo, se verifica en el verdugo. ${ }^{85}$ Dionisio Moiño se dirige a fray Tobías para devolverle el dinero de la paga por su actuación en el ajusticiamiento de Babo. Es una figura que se semeja a la de Judas, como el mismo verdugo señala: "Padre, este dinero es, como el de Judas, dinero de sangre" (200). Este dinero pasa a manos de Dago para comprar la libertad de algunos esclavos. También él se redime al elegir a Francisco a pesar de que "lo detestaba" (203). Entonces, la muerte de Babo provoca un cambio tanto en el verdugo Dionisio como en Dago quien reasume el legado libertario de Babo.

La concepción de la muerte fecundante suscita en Tobías una relectura del Eclesistés: "En parte no se equivocaba el autor del Eclesistés cuando la describía (...) Pero apuesto a que si se lo respira y se lo acata, nada es en vano, ni todo es igual, como casi siempre parece. Estoy jugando a que una semilla germina donde usted no imagina y a que tanto una cruz como un garrote vil pueden ser las seña que al viajero le marquen el rumbo que ha de llevarlo a la casa que le ha sido legada" (203).

También las muertes de Robles y Raneds provocan "la inesperada y entusiasta resurrección de don Benito" (332), el "débil caballero", quien finalmente se decide a proteger la huida de los negros ("nuestro débil

85 No es la primera vez que aparece la figura del verdugo, ya en el capítulo anterior, el Juez revela el oficio de verdugo del padre de Jesús María José, el protector de esclavos. En ese momento la mención del verdugo quedó condenada por el Juez quien justificaba su presencia y oficio en la culpabilidad de todo hombre. 
caballero no le avisó a Delano sobre el motín porque en ningún momento deseó que los negros fueran descubiertos"- dice Dago, 345).

Muri se presenta en el tercer apunte, "El Excluido", como Muri Cereno, el criado personal de don Benito (excluido en el relato de Melville). Su actitud frente a la vida lo opone a la rebeldía de Babo ("es verdad que, si por mí fuera, jamás me habría rebelado", 157) y prefiere adecuarse a las circunstancias sin ir más allá de sus posibilidades: "Si loca es la hormiga que pretenda tener huesos, más idiota es el hombre que desconozca sus límites" (155). Elige la obediencia ("me aterra hacer por mi cuenta lo que durante muchos años hice por obedecer al amo", 157) y la vida cuando Babo le pregunta qué escogería entre "¿la libertad o la vida?". De este modo, Muri es la contrafigura de la rebeldía de Babo, de la rebelión como medio de alcanzar la libertad y de la utopía del regreso a una tierra propia.

Sin embargo, su participación en el motín cambia estos valores, ya que será Muri el elegido como jefe para el grupo de negros que escapa de la fragata buscando fundar una nueva sociedad. A él Dago le aplica la frase yoruba: "fue en ese instante en que caí en la cuenta de que es Muri (...), ni nunca yo, que sólo sé sobrevivir, el primero y acaso el único de nosotros que ha muerto y parido un santo (...) Fui yo y no otro, el que le dijo a Muri cuando entrechocamos nuestras copas: -¡Ikú lobi ocha!" $(341-342)$

Finalmente también Dago va a redimirse. En "La isla de los ciegos" (Segundo Apunte) Dago expone su posición a partir de la necesidad de "sobrevivir" como un acto de salvación que sólo remite a la propia persona y desconoce la solidaridad ("Sobrevivir de la mejor manera posible, al menor costo de mi cuerpo y de mi espíritu, conservando las ganas de seguir sobreviviendo. $Y$ para eso es imprescindible pensar en uno mismo", 118), postura que invierte el 
significado del sacrificio cristiano ("Siempre será posible que, para salvarnos, el uno tenga que sacrificar al otro", 117). Luego del intento de fuga de Aranda, Dago impone la "necesidad" de matar a todos los blancos para ahorrar comestibles y conservar sus cadáveres como alimento del resto de la tripulación. Esta última decisión traduce de un modo brutal la frase yoruba: los muertos alimentan al santo.

Dago es, además, la figura del traidor -"No te puedo prometer que siempre contarás con mi ayuda o que jamás te abandonaré o nunca te traicionaré" (117)- que se arroja de la fragata y nada hasta la costa a fin de salvarse individualmente. Por momentos "La isla de los ciegos" -donde son abandonados aquellos negros que han quedado ciegos por la pesteparece una parábola sobre la ceguera de Dago. Éste ve la enfermedad en un compañero, pero no la suya propia ("y comenzaron a arderme los ojos") y se niega a la solidaridad con quienes morirán en la isla ("Tampoco quiero recordar que son mis hermanos", 122). Ante el destino de muerte, desesperación y canibalismo de los negros abandonados en la isla, Dago cierra los ojos. Tampoco aspira a ningún tipo de salvación "no avizoro ninguna salvación" (121), no apuesta a la utopía de la isla Mocha, la figura invertida de esta isla de ciegos.

La novela contrapone la ley de la "necesidad" de Dago ("Jamás lo persuadiría de que la única fuerza que mueve al hombre es la necesidad que no tiene nada de sagrada, 331) a la figura de Ananké, cuya traducción del griego corresponde a "necesidad" y que en el texto adquiere el valor de la maternidad, reproducción y posibilidad de fecundar la vida. Ananké es la fuerza materna que defiende a su hijo y apuesta a su salvación, es una de las primeras elegidas para escapar en la balandra. Los que irán en la balandra responden a la necesidad de perpetuar la especie pero no descuidan el interés común: "En la balandra y en la lancha se lanzarían al mar, a la incierta búsqueda de la isla Mocha, todos los niños, los vientres 
más jóvenes y más sanos y los tres o cuatros varones más aptos para fecundarlos" (377).

La "liberación" adquiere dos modalidades en la novela. Las prácticas o movimientos libertarios, del motín a la revuelta de Tupac Amaru, culminan en el fracaso pero se revierten -al menos en el caso de Babo- a partir de la caritas y la redención, que, no limitadas sólo a un acto individual, permiten la salvación grupal en la isla Mocha. Los postulados cristianos se resignifican en estrecha relación con las posibilidades de transformación social.

Dago, dijimos, es la figura del traidor, del desertor, quien abandona la empresa comunitaria para salvarse individualmente. Pero él también va a redimirse a partir del arrepentimiento: "-Dago, si volvieras a estar en la fragata, ¿te tirarías al agua?", le pregunta Tobías "-¡No! -me respondió de inmediato y con un énfasis inusual" (376). Tobías entiende este arrepentimiento como un nuevo nacimiento a partir de la muerte de Babo y le regala la frase: "-Ikú lobi ocha..." (376). Este cambio se materializa cuando Tobías le entrega las monedas del verdugo para decidir qué negros podrán comprar su libertad y él elige -siguiendo la "parábola de la viña"- a Francisco.

\section{Los temas}

\subsection{La opresión}

La fragata de las máscaras retoma y expande los ejes temáticos de Benito Cereno, cuyo núcleo se cifra -en la relectura de De Mattos- en la "enigmática escena representada en la parte superior del medallón central: ese negro sátiro con máscara pisando la doblada cerviz de una contorsionada figura también enmascarada. Aseguro que en ella está 
inscrita, por entero, la historia que nos aguarda", afirma MMR (17). En principio se trata de una escena de violencia y sometimiento fundada en la esclavitud, pero no se agota ahí. De hecho, en este caso la figura de quien somete es un sátiro "negro", al contrario de lo que sucede en el texto.

La opresión no se limita al problema de la esclavitud, en principio se extiende hacia los indígenas. Las políticas de dominación aparecen en La fragata... desde dos perspectivas: una simbólica y otra histórica. El texto se abre no con la reescritura del motín de los negros, sino con el encuentro de Bonpland con indígenas del Perú. En "El jardín reservado" se arriba al origen histórico de la conquista como punto inicial del sistema de dominación: el palacio de Cajamarca donde el Inca Atahualpa fue ejecutado por los españoles. El hijo del cacique Astortilco le muestra las ruinas del antiguo palacio.

La imagen del "origen" se tiñe de elementos míticos que procuran explicar la historia de la opresión. El "paraíso perdido", el "Edén" de los incas está sumergido bajo las ruinas donde su último emperador fue muerto por Pizarro: "Nos está contando que debajo de los escombros que acabamos de visitar, se sabe que existe un valiosísimo tesoro, cuyo acceso subterráneo está marcado por un árbol enterrado, de plata y oro, que imita, quizá estilizado, las formas del guaneo" (67). El mito bíblico de Caín sustituye al del Edén: "Imagino que juega con la idea de que al atravesar el Atlántico no llegamos a otro espacio del planeta sino a otro tiempo. A un ámbito donde, si la naturaleza recuerda a cada paso a la que reinó en el Edén, también muestra despojos que avisan que Caín ya mató a Abel" (69). Esta perspectiva tiene hondas raíces en la tradición literaria latinoamericana y ecos particulares de El Siglo de las Luces (1962) de Alejo Carpentier. 
La comparación con la novela de Carpentier puede servirnos para apuntar los perfiles que De Mattos da a la naturaleza y al origen, si bien sospechamos un contacto más profundo entre ambas, en tanto se refieren a un período similar -"el siglo de las luces"- y abordan el problema de la esclavitud. En El Siglo de las Luces Carpentier inserta su fábula del origen a partir de la imagen de la naturaleza primigenia, nueva y adánica de América Latina que sucesivamente denomina "Paraíso Perdido", "Hespérides sin nombre" y "Mundo de lo cámbrico". Con lo cual retoma y redefine una larga tradición sobre el tema que contaba con dos líneas contrapuestas: de Buffon a Hegel se sancionó una posición eurocentrista que hacía de la naturaleza latinoamericana signo a la vez de inmadurez y decadencia; del lado contrario y en la línea que va de Humboldt a Spengler la naturaleza americana se percibe como un mundo nuevo lleno de posibilidades, como un "Urzeit"; a lo cual debe añadirse la figura del Paraíso perdido de los Diarios de Colón. Evidentemente, Carpentier retoma esta segunda línea para describir desde su programa del realismo maravilloso la exultante naturaleza latinoamericana. ${ }^{86}$

Tomás de Mattos le da un giro a la perspectiva carpenteriana o a la tradición que la sostiene al enterrar el Paraíso Perdido de los Incas debajo de las ruinas de la opresión gestada por la conquista. Instaura en las tesis humboldtianas del Urzeit una temporalidad signada por la presencia de Caín: "En verdad, la barrera que separa a esta tierra de Europa, no se levanta con millas de mar desapacible, sino con siglos de molicie y opresión" (69). Si en la novela de Carpentier la naturaleza que Esteban experimenta se encuentra como un reducto al cual acudir frente

86 Cfr. Teresa Basile, "La naturaleza como discurso sobre la identidad latinoamericana", en La educación. Revista interamericana de desarrollo educativo, Año XXXVI, No. 111-113, 1992, pp. 75-88. Varios son los autores que se ocupan de analizar esta tradición, por ejemplo: Antonello Gerbi, La disputa del Nuevo Mundo, México, FCE, 1982 ; Ortega y Gasset, "Hegel y América", en El Espectador, Madrid, 1928; Mary Louise Pratt, "Humboldt y la reinvención de América", en Nuevo Texto Crítico 1, 1988. 
al régimen de opresión que instaura Víctor, La fragata... recoloca la naturaleza y el mito del paraíso perdido bajo la experiencia de la opresión (Caída del Edén y presencia de Caín).

Dijimos más arriba que el tema de la violencia, inscripta en el sistema de opresión de la esclavitud, se vierte de dos modos: en la trama y en un conjunto de símbolos. En ambos se inserta la tensión entre sistemas de dominación y emprendimientos libertarios. La novela construye una serie de paralelismos entre momentos históricos relevantes de América Latina y relatos míticos occidentales: Paraíso perdido/ libertad; Caín/ conquista española; Utopía/ movimientos revolucionarios. El nivela mítico sirve para colocar la historia de América Latina en una temporalidad "universal".

En el cuarto apunte, "El espejo de la Medusa", Tobías expone el nivel simbólico del texto. El antiguo nombre de la fragata dado por Benito, "El juicio", señala la elección que hace cada individuo en su vida: "el nombre apuntaba a otro tipo de travesía, mucho más importante y a la que ninguno de nosotros podrá soslayar con desestimientos o transacciones" (210). Aquí, la concepción del "juicio" se desprende de la versión escatológica del "Juicio Final" y se seculariza para señalar la elección de un destino acorde a ciertas leyes que, como a libertad humana y el amor, el texto postula como universales. Esta idea del "juicio" -que no obstante conserva algunas astillas de la concepción cristiana- se opone a la justicia humana que Tobías rechaza.

En el espejo de popa Tobías interpreta otra serie de símbolos a partir de las figuras mitológicas. Sus diez medallones pequeños representan diversas escenas de lucha como las de Hércules con Nereo, Jacob y el Ángel, Prometeo encadenado, Caín y Abel, Lucifer y el arcángel Miguel, Elías y el sacerdote de Baal, el sueño de Mardoqueo, Adán y Eva, Noé y la paloma e Ícaro. Los dos medallones centrales 
presentan la figura de un enorme pez, "el Leviatán, la Esfinge acuática, la ballena de Job, de Jonás y de Acab", que encara al espectador considerado como el "adversario omitido" (213). En el otro medallón Neptuno está por darle un beso a la Medusa cuando ella comienza a transformarse de virgen en monstruo.

En los diez medallones pequeños, las escenas de lucha se abren a diferentes posibilidades, desde el fratricidio hasta la búsqueda de la sabiduría, desde la caída hasta la nueva tierra de Noé. La vida es percibida como una contienda entre fuerzas opuestas siguiendo la postulación del doble principio del bien y el mal. El medallón del Leviatán enfrenta al hombre en soledad con la desmesura inaprensible del universo; mientras en la figura de la Medusa se cifra la posibilidad de la liberación a partir del beso; el rescate de la Medusa por parte de Neptuno pone en juego el beso como símbolo de la caritas. Estas escenas invitan a la elección y al compromiso por parte del espectador, en la certeza de que la vida coloca al individuo ante algún tipo de combate. Tobías marca su propia elección ante las tallas: "Presentí que nos hermanaba una idéntica predilección por la Medusa, por Prometeo, por Abel, la primera víctima; no dudé que abominaba a los dos dragones y al águila, pero que comprendía el desconcierto de Caín y que no temía encarar, con Jacob o Ícaro, al Ángel o la incandescencia de las alturas o a Proteo o al Leviatán" (221). Las interpretaciones de Tobías parten de su postulación de la vida como lucha entre dos principios -"lo diáfano y lo perverso" (221)-, en contra del monismo del dogma cristiano ("el escultor (...) procuró recrear ese precario, delgado y casi imponderable equilibrio entre dos reinos antagónicos pero tan difícilmente discernibles", 221). Invita a elegir entre uno u otro principio, entre la opresión o la liberación. La Medusa besada por Neptuno -reinterpretada de un modo particular- representa esta imagen de liberación y de apuesta por los débiles y los vencidos. Dice Tobías: "¿Por qué el beso no podría ser redentor?" (221). La imagen 
de la Medusa como posibilidad de transformación liberadora, de redención, de pasaje y conversión del mal al bien se conecta con la frase central de la novela "¡Ikú lobi ocha!" que ya analizamos.

Las tres imágenes parecen establecer una sucesión temporal que, a su vez, la novela sigue. Primero la lucha entre los hombres, luego el combate con el Leviatán y finalmente la posibilidad de redención. El motín está escandido en esas etapas: la extrema violencia inicial con las muertes y matanzas de Aranda y los suyos representa la primera etapa de contienda entre los hombres; firmado luego el armisticio se ingresa a las decisiones mayores de la elección del destino, del enfrentamiento con el Leviatán: "Francisco decía hace un rato que la paz está con nosotros. Y es verdad. Sólo nos queda un único adversario: ¡el mar! ¡Este inmenso mar que nos separa de la que será nuestra tierra! ¡Una tierra en la que mandan los negros y en la que no existen esclavos!" (329). Finalmente el beso de Neptuno a la Medusa se corresponde con la solidaridad de Tobías por los débiles guiado por el amor, por la caritas.

La violencia también tiene que ver con la escritura, y en América Latina este problema se centra en hechos históricos precisos ya que la conquista implantó un sistema de escritura como herramienta principal de la colonización. La novela introduce cierta concepción de la escritura vinculada por un lado a "la versión de los vencidos", como se desprende de las palabras de Muri a Melville: "No lo culpo de haber leído tan sólo papeles de vencedores" (153), y que el texto procura desarmar a partir de las voces de los negros. Pero también subyace en La fragata... la idea de una escritura que tiende hacia el infinito, que no se agote y concluya en las respuestas, sino que éstas sean seguidas por nuevas preguntas, tal como dice Tobías: "Monsieur: las respuestas traen siempre otras preguntas cada vez menos fáciles de contestar" (345). Es Vattimo quien 
reflexiona, al oponer el dogma a la hermeneusis cristiana, sobre la violencia de la palabra en estos términos al afirmar "la violencia implícita en toda ultimicidad, en todo primer principio que acalle cualquier nueva pregunta". ${ }^{87} \mathrm{La}$ escritura como un "palimpsesto" que acumula diversas capas, que escribe y borra sobre lo ya escrito, aparece en la escena final, cuando Muri se acerca a la tortuga mítica, símbolo de la historia escrita por todos, del tiempo que supera la vida de un individuo, superficie en la que se han escrito las historias de batallas por la liberación y en la cual finalmente Muri hará su propio trazo: "Paulatinamente mientras el negro ha ido raspando y limpiando, una a una, aquellas cicatrices tan diferentes entre sí, a veces extrañamente ensanchadas e hinchadas, a veces casi borradas, a veces inscritas sobre otras más viejas como si las conchas fueran, capa a capa, un misterioso palimpsesto, la tortuga eterna, obsesivamente dedicada a vencer el obstáculo de la roca, se ha agrandado y transfigurado" (395).

Si ¡Bernabé, Bernabé! inscribía en el origen nacional, el exterminio charrúa; La fragata.... se desplaza al origen de América Latina como punto inicial de las políticas de opresión de indígenas y negros.

\subsection{El motín o la revolución}

El motín, podemos postular, se convierte en una metonimia de la revolución, tema que aparece en reiteradas oportunidades. La fragata... no incluye el relato de otra revolución, sólo las menciona, pero basta para articular una línea de revoluciones latinoamericanas de negros e indios, como el levantamiento de Túpac Amaru $(1780)^{88}$ y la revolución de

87 Vattimo, Gianni, op. cit., p. 77.

88 Tobías fue investigado por la Inquisición por participar en la revolución de Túpac Amaru: "me lamenté luego, durante algunos meses, haberle contado todas mis cuitas como capellán, aparentemente preso, del ejército de Túpac Amaru. A don Benito esa 
Toussaint L'Ouverture (1794). ${ }^{89}$ Uno de los notables desplazamientos de La fragata... frente a Benito Cereno consiste en incorporar al tema central de la opresión de los negros, al indio, diferencia en el tratamiento del dominio sobre los subalternos que no deja de señalar la novela, tal como los reúne Bonpland en su retablo ("mi habitación se ha llenado de indios y negros que conforman contra la pared de enfrente un grotesco retablo", $56)$.

No podemos soslayar las resonancias del nombre de Túpac Amaru en el de los tupamaros, aunque tampoco podemos asegurar una voluntad de vincularlos de un modo directo. Pero sí creo lícito constatar ciertas cuestiones. Por un lado, esta novela, publicada en 1996, fue pensada desde mucho años y anunciada en el prólogo de iBernabé, Bernabé! (1988). En una entrevista Tomás de Mattos asegura que "siempre pensó que, no el Bernabé, sino ésta novela sería "la polémica". ${ }^{\circ 0}$ La fragata... fue, entonces, ideada ni bien terminó la dictadura y su autor temió que suscitara una "polémica". Podemos sospechar, por otro lado, que cualquier lector uruguayo iba a vincular inmediatamente ambos nombres y que esto podía desatar un debate. Sin embargo y como para desmentir mi presuposición, ninguna de las reseñas y extensos comentarios sobre La fragata de las máscaras menciona la asociación Túpac Amaru/tupamaros, ni siquiera ponen en relación a la novela con el

aventura mía lo impactó. Le costó creer que un fraile, e hijo, por otra parte, de una adinerada familia, le describiera con inocultable simpatía todas las vicisitudes de una borrascosa rebelión de indios campesinos" (103).

89 La fragata de Benito se llama "Santo Domingo", tal como aparece en el texto de Melville, pero en el prólogo de Tomás de Mattos a Benito Cereno nos dice "Los nombres de los barcos fueron cambiados..."El Juicio" fue rebautizado "Santo Domingo", probablemente en alusión a la isla de Toussaint L'Ouverture" (6). Dago además recuerda la impresión que causó en Babo el relato por parte de Charles Marie Querry, de la gesta de Toussaint L'Ouverture (281).

90 "Próxima navegación de Tomás de Mattos". Entrevista de Ana Inés Larre Borges, en Brecha, 9 de octubre de 1992, Montevideo. 
presente." ¿Habrá que analizar esta recepción como un signo del presente?

Sin dudas, la revolución, abordada en la novela desde el fracaso ("Lo que ocurre es que aquí (...) ya tuvimos una Revolución (...) Pero perdimos", 55), obliga a reformular el futuro. ¿Qué es posible hacer a partir de la derrota de los movimientos libertarios de América Latina? ¿Cómo evaluar las derrotas y cuál es el paso siguiente? La muerte de Babo como posibilidad de una redención sostenida en la idea de caritas, de "amor al prójimo", se corresponde con la necesidad que Bonpland reclama de construir América Latina "entre todos". Ambas propuestas se vehiculizan en la cooperación de múltiples voces. Por otro lado, De Mattos invierte el final deceptivo de Benito Cereno y coloca como una deliberada invención la llegada a la isla Mocha de un grupo de negros, que parece recuperar la posibilidad de una praxis libertaria.

\subsection{El juicio}

En el capítulo tres, "El reino de la indignidad", comienza el juicio contra Babo y el resto de los negros amotinados. Allí comparece Babo y el Juez Martínez de Rozas lo recibe con las mismas palabras de Pilatos a los judíos ante un Jesús azotado, llevando la corona de espinas en la cabeza y un manto de púrpura en los hombros: "Ecce homo". ${ }^{92}$ De entrada se coloca a Babo como un Cristo negro: "Ecce niger" (127), responde José Abos en un juego de palabras que trasunta la diferente interpretación que ambos dan a sus dichos: mientras el Juez se coloca en el lugar de

91 Cfr. Ana Inés Larre Borges "La fragata de las máscaras. Revolución a la deriva", Montevideo, Brecha, 31 de agosto de 1996; Ana Inés Larre Borges, "Próxima navegación de Tomás de Mattos. Entrevista", Brecha, Montevideo, 9 de octubre de 1992 y Carina Blixten, "La novela es una masa de hojaldre", Montevideo, Brecha, 28 de abril de 2000 .

92 Evangelio de San Juan, cap. 19, versículo 6. 
Pilatos, para José Abos se trataría de una nueva víctima de la justicia colonial. La condena de Cristo es interpretada a partir de la Biblia como la expiación de "los dolores del justo" y es éste uno de los sentidos que alcanza en la novela..$^{93}$

La escena del juicio pone en cuestión, critica, la justicia humana como un sistema de opresión que castiga a los débiles y así surge en el discurso iracundo de Tobías luego que ha caído la cabeza de Babo, en el cual la Biblia funciona como significativo genotexto:

"No interesa, monsieur, lo que dije. Para imaginarlo basta haber leído la Biblia. No hice otra cosa que hilar pasajes que me sé de memoria y eso, según Cisneros, fue lo que providencialmente me salvó, más allá de las sinuosas argucias del dictamen del Santo Tribunal, porque condenarme implicaba trasuntar el rechazo de la palabra de Dios que pervierte o embrutece a más de uno de sus ministros. Si quisiera tener una idea más concreta, aparte de los Evangelios, lea a mis profetas predilectos: Jeremías, el pacifista; Amós el justiciero. En realidad, el primer texto que cité desde el cadalso, pertenece al muy peligroso Eclesiastés" (199).

Si interesan para la interpretación de la novela estos lazos explícitos con el discurso bíblico, mucho más cobran peso cuando atendemos a los pasajes elegidos del Eclesiastés, la visión pesimista de la existencia ("vanidad de vanidades y todo es vanidad") tiñe los sentimientos de Tobías frente al ajusticiamiento de Babo, para luego recuperar la esperanza de redención que esa muerte instaura. También el Eclesiastés habla sobre la injusticia a que son sometidos los oprimidos, así como las profecías de Amós protestan y reclaman castigo contra la opresión de ricos y poderosos, o las de Jeremías que se unen a esta condena.

93 Cfr. Sacramentum Mundi, Tomo 4, p. 23 
El capítulo sobre el juicio contrapone los valores del castigo y del perdón, el castigo impuesto por el tribunal se opone al pedido de fray Tobías de "la absolución del negro Dago" (150) solicitada por los padres del Monte Agonía. Las alternativas involucran la idea de perdón, privilegiada por Cristo, frente a la sed de justicia judía del Antiguo Testamento.

El juicio en la novela no sólo no contempla el perdón sino que se ejecuta mediante un castigo que encierra la venganza ("iQuebrarle no el gaznate que todos, incluso él, sabemos que lo vamos a hacer y con el mayor rigor que esté a nuestro alcance! ¿Quebrarle el alma! ¡Deshacérsela!") y la tortura.94

El juicio como "reino de la indignidad", claudicación del alma, atañe no sólo al caso de Babo;" ${ }^{5}$ luego de la audiencia, los magistrados van a lo de Bernazza a compartir unas copas y allí el Juez Martínez busca quebrar al Protector de los Esclavos descubriendo rumores sobre la

94 El problema de la justicia adquiere una enorme complejidad en el seno del cristianismo, el cual distingue entre "el concepto religioso de justicia y la idea de justicia como una virtud especial". En las teologías neotestamentarias, la "justicia de Dios" se alcanza "mediante la fe y el bautismo", pero junto a ella se encuentra la "justicia exigida al hombre" que designa la "conducta moral humana como presupuesto para recibir el espíritu" inscripta en las enseñanzas de Cristo a partir del sermón de la montaña y de los mensajes de Cristo que apuntan fundamentalmente al perdón ("El perdón cristiano", Mateo, 18, 18).

95 Este juicio es narrado con cierta distancia y perspectiva crítica y también autocrítica por José Abos quien en su calidad de magistrado participa del juicio. José Abos, hermano de Tobías, se autocontempla desde los ojos de Babo de quien supone le dirige una mirada de burla y le descubre su máscara: "el negro me regaló una mirada de ostensible desprecio. Me fue evidente que el boato no me aclaraba la piel y que mi peluca (...) descubriría por algún lado estas mis motas tan africanas. Sin duda le impresioné como un mulato disfrazado de magistrado" (128). En parte José Abos mantiene un perfil crítico frente a la justicia, pero a su vez no toma ninguna actitud decididamente a favor de Babo. Del mismo modo Jesús José María Etcheberriaga Oyarzún, el Protector de Esclavos, si en principio procura ahorrarle los tormentos a Babo, finalmente accede ante el mandato inapelable del juez. Sin falsas expectativas, el Protector de Esclavos reconoce "¿Qué otra cosa hubiera podido hacer, José, si por derecho el viejo me puede acogotar a todos los negros y tú y yo sabemos que no se va a conformar con una docena?" (139) 
ocupación de su padre como verdugo del pueblo, ante lo cual Jesús María José se avergüenza y huye. "No era sólo al negro al que había que quebrar" (147), piensa José Abos. La continuidad de ambas escenas pone en claro la imagen de Juez en Martínez y su concepción sobre la culpabilidad de todo hombre como propia de la condición humana. ${ }^{96}$

El juicio resultó para José Abos "particularmente ignominioso. A ningún magistrado, e incluyo a Martínez de Rozas, cuyo cinismo esconde a un liberal desencantado, le reconforta servir a una Justicia que castiga a unos infelices que, si bien se los mira, sólo buscaban recuperar u obtener por primera vez su libertad" (99).

"Las máscaras de la muerte", el capítulo siguiente, resulta en buena medida una reescritura a contrapelo del juicio. Cuando Tobías se acerca a Benito para asistirlo en la agonía, inesperadamente resurge el "secreto", objeto privilegiado de las averiguaciones del fraile, porque el moribundo clama "¡Muri! ¡Diamelo!... ¡Se les hunde la balandra! ¡Negros míos!" (169). Pero a diferencia del intento de sacarle la verdad a Babo a partir de la tortura, Tobías se retira ante la necesidad de "respetar la intimidad". Del mismo modo el trato de Tobías frente a Babo -horas antes de su ejecución- resulta la contrapartida del juicio ("mi objetivo no se apartaba demasiado del que animó al juez Martínez. Doblegar al negro, aunque no para lastimarlo, sino para restañarle el corazón. Tumbarlo, pero no en la ignominia de la claudicación, sino en el auténtico reencuentro consigo mismo" ,179)

La mirada -tema recurrente- se articula como "fisgoneo" en el acercamiento de Tobías a los negros condenados, índice de respeto y distancia frente a sus intimidades y secretos ("Para fray Angélico y Cisneros este fisgoneo previo les resultó incomprensible. Me reprochan

96 El juez Martínez remite a la figura de Edipo, ya que su hija se llama Antígona. Me refiero al Edipo que en el inicio de la tragedia de Sófocles promete la búsqueda y el castigo del culpable. 
que, en vez de abrir la puerta y entrar acompañado por los custodios, me haya demorado en la ventanuca. Para ellos, no sólo fue una pérdida injustificada de mi autoridad moral sino, por añadidura, un signo de inexcusable vacilación", 181). El deseo de acceder a la verdad por parte del fraile se diferencia tanto de los métodos de tortura del juez como de la confesión propia de la institución eclesiástica.

Casi como una conclusión que sostiene una evaluación a la vez distante y comprometida, Tobías dice sobre Babo: "Lejos de mí empuñar la vara de la justicia. No nací ni para seguir ni para perseguir a ese jefe. Otra huella es la que es escogido. Pero (...) no es repudiable ningún destino cabalmente asumido" (382).

\subsection{El guano y la tina}

El fraile Tobías será también el encargado de alertar acerca del error de postular una frontera sólida -propia del monismo cristiano- entre el bien y el mal ("el bien y el mal no se alimentaban a sí mismos y crecían en una espiral irrefrenable, alejándose el uno del otro, sino que, por el contrario, se alternaban, produciéndose recíprocamente, a veces con una angustiosa inestabilidad. A veces con una dinámica tan serena y armoniosa que parecía preestablecida", 52). Las creencias afroamericanas convalidan esta concepción que la novela expande a partir de diferentes religiones e imágenes, entre ellas el guano que Bonpland prueba con su boca y donde el excremento de las aves se convertirá en una de las riquezas de Perú. ${ }^{97}$ Esta imagen es paralela a la de la "tina": "Aún está en el primer patio, donde mandó instalarla don Gabriel contra la voluntad de toda la familia. Dicen que es una fuente de mármol de Carrara y en

97 Cfr.: "Los orixás, Ismael, se aman pero también se odian (...) persiguen, igual que nosotros, ideales antagónicos. Créame que las convulsiones no reflejan un universo armónico", (235) 
cuanto al material no mienten, pero tan sólo es una gigantesca tina, guarnecida por cuatro mastines rampantes y tres esclavos armados, que le recuerda a todo visitante la sacrílega fundación de la familia (...) Diríase que ahora se regodean en su misma insolencia..." (64). La tina alude al origen de Tobías y simboliza el mestizaje latinoamericano: "Es evidente que fray Tobías discurre tanto sobre la milenaria partida que, según él, el bien y el mal vienen jugando, en todos los lugares y seres de este mundo, porque le agradece nada menos que su nacimiento a esta inacabada pulseada. No ha tardado en decirme que no se avergüenza de ser bastardo, adulterino y cuarterón" (59). La referencia al guano y a su propio origen convierten al dualismo en una herramienta privilegiada para comprender la historia de América Latina.

\section{La utopía}

Otro de los cambios más notables de La fragata... con respecto a Benito Cereno consiste en el final del motín. Mientras en la nouvelle de Melville Babo salta detrás de Benito Cereno a la ballenera de Delano, en la novela de De Mattos, Babo instaura la utopía al permanecer y organizar el escape de un grupo de negros.

El peculiar tratamiento de la utopía radica aquí en dos cuestiones. Por un lado se trata de una "utopía menor". Se proponen diversas alternativas: Babo -según dice- quiere llegar al Senegal pero termina despidiendo la balandra hacia la Isla Mocha, cerca de Chile. Se contraponen, entonces, el Senegal como cabal utopía a la "utopía menor": "La isla Mocha dista de ser una isla encantada" (393). Enfoque similar a la "pequeña utopía" reclamada por Achugar en lugar de la "utopía servida en bandeja". 
Por otro lado, se discute insistentemente sobre la posibilidad real de alcanzar el Senegal, y se inquiere sobre las condiciones de éste como espacio utópico. No se trata ya de un no lugar sino de un lugar concreto, al que se arriba luego de navegar una considerable distancia y que tiene determinadas formas de gobierno y donde incluso existe la esclavitud ejercida por los mismos negros contra sus hermanos. Veamos algunas citas: Dago interroga a Raneds: "¿Podemos llegar al Senegal con esta fragata ruinosa?" (284); "le pregunté si era el Senegal tierra hospitalaria para los otros negros y si lo era para los propios mandingas -ya que precisamente allí fue que Babo había nacido esclavo de dueños que todavía no eran blancos" (298); "Para el pichón de Muri, lo que realmente habría querido (Babo) era que no nos enredáramos en metas alcanzables. Nos habría empujado a lo impensado para que no nos dividiera lo pensable" (307).

La imagen de la utopía está trabajada mediante configuraciones simbólicas. Josefina describe y adapta la pintura de Géricault, La balsa de la Medusa, a la situación de los personajes de la novela, convirtiendo a los sobrevivientes en negros y destacando la figura de Ananké y su hijo. La utopía se cuela en la imagen de la tortuga hallada por Muri en la isla Mocha, expresión de una temporalidad que el hombre ha gestado pero que también la sobrepasa. En su superficie están escrita las historias de las luchas libertarias a las cuales Muri parece añadir la propia: "su colosal escudo está, entonces, copiosamente mellado y abollado por las incontables batallas que ha arrostrado para seguir alentando en este mundo" (395). La tortuga aparece -similar al caracol en El Siglo de las Luces- como la escritura de la naturaleza que se empeña en seguir viviendo y procreando. 


\section{La posdictadura desde la herencia cristiana}

Como sucedía en !Bernabé, Bernabé!, Tomás de Mattos también aquí duplica y desplaza su propio locus de enunciación hacia Josefina para articular el presente con el pasado. La escritura de La fragata... se origina a partir de un pequeño escándalo protagonizado por Josefina el domingo 26 de noviembre de 1855, día en que suceden dos acontecimientos. Se festeja la toma de Sebastopol por las tropas aliadas en el marco de la guerra de Crimea, mientras el día anterior "había estallado en la ciudad una inoportuna revolución y los alzados se habían apoderado del Fuerte, que así se llama la sede del gobierno" (23). ${ }^{98}$ Josefina se fastidia por el festejo de una victoria en momentos en que en Uruguay ha estallado una revolución: "La frivolidad, la hipocresía y el ostensible desdén por los acontecimientos de nuestra tierra que cundían entre los comensales, me fueron sacando de quicio" (23). Bonpland se pone de su lado y le cuenta el motín como una respuesta oblicua a su altercado.

De este modo el relato del motín aparece como un desplazamiento del conflicto actual de Josefina; es decir Bonpland actualiza el motín de Babo desde la coyuntura presente -la falta de atención hacia los conflictos

98 Al finalizar la Guerra Grande (1843-1851) y fracasada la politica de fusión tendiente a cancelar las viejas divisiones, comenzó o se reanudó una etapa de guerras civiles entre la diversas facciones. El período que va de 1851 a 1886 será de convulsiones continuas y contradictorias y se sucederán 43 movimientos entre revoluciones, motines, alzamientos. En el caso de Josefina se trata del levantamiento de José María Muñoz y su grupo de conservadores que asalta victoriosamente el Cabildo, se pelea en las calles por varios días y Muñoz termina derrotado y desterrado. Lo que significa un nuevo fracaso del intento de pacificación y entendimiento entre los diferentes grupos y que tuvo en las palabras de Lamas una expresión adecuada cuando sentenció en su Manifiesto de 1855: "Rompo pública y solemnemente esa divisa colorada (...) que no volverá a ser la mía jamás; no tomo, no, la divisa blanca, que no fue la mía, que no será la mía (...) ¿Qué es lo que divide hoy a un blanco de un colorado? Lo pregunto al más apasionado y el más apasionado no podrá mostrarme una sóla idea social, una sola idea moral, un solo pensamiento de gobierno con esa división", tomado de: Carlos Machado, Historia de los Orientales, Tomo 2, Montevideo, Ediciones de la Banda Oriental, p. 72. 
uruguayos y el levantamiento en Montevideo como puesta en escena de la imposibilidad de una política de unidad entre las diferentes facciones políticas. ¿Dónde radica la similitud que convierte al motín en una respuesta oblicua a la guerra fratricida que asedia a Uruguay? Creo que la respuesta puede pensarse a partir de la necesidad que Bonpland esgrime de construir América Latina "entre todos".

En buena medida podemos pensar que es una puesta en abismo de la relectura que hace Tomás de Mattos de la política del Uruguay, atravesada por enfrentamientos radicalizados entre grupos e ideologías que hicieron inviables los programas fundados en la comprensión y en la unión.

A la coyuntura del presente, Josefina le añade otro dato: el puerto de Montevideo fue el lugar de embarque de buques esclavistas. En Benito Cereno el barco "Santo Domingo" partía del puerto de Valparaíso rumbo al Callao con el cargamento de productos del país y un grupo de ciento sesenta negros. Cuando Delano lo aborda, Babo inventa, para justificar una larga travesía, la partida desde el puerto de Buenos Aires rumbo a Lima. Josefina incluye un episodio inédito en Benito Cereno pues hace partir de las costas de Montevideo a la fragata "Neptuno" con don Benito, Dago, Aranda, Babo y Pastora "sin que ninguno supiera que aquí, en esta zona arbolada que se extiende al pie del Cerro, se construiría, recién iniciada la dominación portuguesa, una casona, en cuya segunda planta una viuda borronearía, casi un siglo después, el trágico destino que tras muy pocos años les aguardaba a casi todos ellas" (230). De Mattos también inventa el nombre de Ananké y la hace provenir de Montevideo, como asimismo proceden de ella los esclavos que Aranda embarca en la fragata de Benito. ${ }^{9}$ Esta insistencia busca dejar bien en claro que

99 Cfr.: "Eran Ananké y su hijito; la negra con cría que el hermano de Alejandro nos había enviado desde Montevideo" (277) y "Y don Alejandro erizó al chileno, llegando en compañía de cincuenta negros, procedentes de Montevideo" (88). 
Montevideo ofició como puerto clave en el tráfico de negros, ${ }^{100}$ pero la inclusión de estos datos cifra la voluntad de "latinoamericanizar" al Uruguay.

Además, Josefina enfoca la mirada final de Babo hacia el sur y hacia el futuro: "Pero para comprender comportamientos inexplicables también nos fuimos al pasado que vislumbrábamos a través del expediente que usted transcribe hacia el final de su novela. E, incluso, ya lo comprobará, incursionamos por el futuro. Yo tengo, por ejemplo, muy claro por qué el negro Babo, a punto de ser ejecutado, volteó su última mirada hacia el sur más remoto" (32).

El sur aparece a través del sintagma del "pez amarrado" tomado del capitulo 89 de Moby Dick. Este "pez amarrado" no se refiere sólo a los esclavos, dice MMR "es -como más de una vez sugirió Josefina- muy aconsejable para la gente llamada a vivir en el Sur" (20). En dicho capítulo de Moby Dick, Ismael comienza analizando las leyes sobre la pesca de ballenas para culminar en una parábola sobre las naciones y los hombres: "¿Qué era América en 1492 más que un pez suelto, en el que Colón clavó su estandarte español como pértiga señaladora para sus reales amos?".01 En múltiples ejemplos, Ismael presenta la historia de la humanidad como una batalla por la conquista, la colonización, el saqueo y la dominación de los estado poderosos sobre los más débiles. Tomás de Mattos remite esta frase al presente en una de sus entrevistas: "Y quien quiera medir las relaciones de Melville con nuestra actualidad, entre tantísimos pasajes, puede acudir a la lectura del admirable capítulo

100 Cfr. Agustín Beraza, Amos y esclavos, Enciclopedia uruguaya No. 9, Montevideo, 1968 e Ildefonso Pereda Valdés, El Negro en el Uruguay. Pasado y Presente, Montevideo, 1965.

101 Herman Melville, Moby Dick, Porrúa, México, p. 296. 
LXXXIX, de Moby Dick, centrado en la fábula del "Pez amarrado y pez suelto". ${ }^{102}$

Más que dilucidar el alcance múltiple que la idea de pez amarrado convoca -las diversas formas de dominación en la historia de América Latina-, me interesa la postulación de una continuidad entre diferentes momentos históricos como la conquista de América, la esclavitud ("Voces africanas (...) Voces, pues, de peces amarrados", 33) en el motín de Babo, la coyuntura de la guerra civil para Josefina y el presente para Tomás de Mattos. Si bien es cierto que toda novela histórica ( $\mathrm{y}$ toda indagación histórica) se hace desde el presente, las novelas de Tomás de Mattos aquí analizadas establecen, además, una continuidad, hacen de la historia una repetición que procura explicar ciertas constantes de la historia del Uruguay y de América Latina.

La relectura del pasado desde el presente se legitima en esta novela a partir de la idea de hermeneusis inscripta en el mensaje de Cristo. Si la Iglesia y la tradición se postulan como mediadoras en la interpretación de la Biblia, el concepto de "secularización" de Vattimo anteriormente mencionado propone la relectura del mensaje cristiano a partir de los "signos de los tiempos" y no del dogma como texto concluso.

Tobías hace explícita esta estrategia frente al espejo de popa: "¿Por qué la escena tenía que estar indisolublemente atada al pasado y al futuro que el mito le ha asignado? ¿No teníamos derecho, tanto el escultor, como yo, su humilde contemplador, a darle otro sentido, si éste era el que más intensamente nos removía el alma? ¿Qué motivo insoslayable nos obligaba a ordenar los hechos en el tiempo como se le había ocurrido al ideador del mito?" (221).

102 "Próxima navegación de Tomás de Mattos", op. cit., p.19. 
El Concilio Vaticano II (1962-65) puso en práctica un aggiornamiento que significó un vuelco desde el dogma hacia las demandas del presente e implicó una apertura de la Iglesia hacia los movimientos renovadores del mundo contemporáneo, reconociendo la legitimidad de importantes experiencias sociales de pueblos enteros y las aspiraciones de los sectores más pobres y oprimidos. En la encíclica Gaudium et Spes se anuncia que la Iglesia debía "escrutar a fondo los signos de los tiempos e interpretarlos a la luz del Evangelio". ${ }^{103}$ Este concilio significó un gran impulso transformador durante la década de 1960 en ciertos sectores de la Iglesia de América Latina -también creó conflictos- que vincularon la renovación de la Iglesia con los movimientos revolucionarios: "Como instrumento ideológico adecuado a su nueva posición, estos sectores destacan en sus análisis aquellos pasajes del Nuevo Testamento que hacen referencia al potencial revolucionario de la ideología cristiana". ${ }^{104}$ Contra esta Iglesia de izquierda, revolucionaria y tercermundista se van a enfrentar las dictaduras de los setenta.

Sin necesidad de postular un vínculo estrecho con las posturas de la Iglesia tercermundista, las propuestas de La fragata de las máscaras no se comprenden sin este contexto. La II Conferencia General del CELAM (Consejo del Episcopado Latinoamericano) realizada en Medellín (1968) preparó un documento "Sobre la violencia en América Latina" en el cual sostenía que "América Latina, desde hace varios siglos, es un continente de violencia". ${ }^{105}$

De un modo general La fragata... reconfigura a Cristo en Babo a partir de estos cambios. La identificación de Babo con Cristo implica una

\footnotetext{
103 Vaticano II. Documentos Conciliares, Bs. As., Ediciones Paulinas, 1988.

104 AAVV, Cristianismo: doctrina social y revolución. Con prólogo de Marta Cavillioti, Bs. As. Centro Editor de América Latina, 1972.

105 AAV, Cristianismo: doctrina social y revolución, op. cit. p.23.
} 
interpretación especialmente atenta a "los signos de los tiempos", secularizante y bastante libre en la cual se acentúa su perfil rebelde y revolucionario. ${ }^{106}$ Se distancia, en cambio, de ciertas posturas tercermundistas que justifican el uso de la violencia como arma para combatir la violencia del el poder. En este sentido, Tobías se lamenta de las muertes acaecidas durante el motín (382).

La experiencia de la dictadura y la etapa de conflictos y luchas que la antecedió desnudó la dimensión fratricida del terrorismo de Estado y los enormes disensos que fracturaban la nación. Estos enfrentamientos ponen en el centro del debate dos cuestiones. Por un lado revisan la concepción de nación homogénea que en parte, ahora se percibe, fue forjada por políticas autoritarias que no contemplaban la totalidad de las subsociedades que compartían el territorio. Surge, tal como sostiene Teresa Porzekanski, una voluntad por recuperar al menos simbólicamente las identidades segregadas y se reinstalan los temas de la "indianidad" y la "africanidad". En esta línea las dos novelas de Tomás de Mattos resultan paradigmáticas. Pero ¿Cómo se representa al "otro"?. El concepto de "subalternidad" puede ser útil ya que permite -más allá de las identidades sesgadas por la clase social- abordar los cruces que, articulando otros rasgos diferenciales, vinculan a Josefina, los indigenas y negros. La estrategia de Tomás de Mattos para representar al subalterno, consiste en interpelar el par centro-periferia y sus sucedáneos a partir de un doble movimiento: fracturar hacia dentro la representación homogénea y cristalizada de los negros marcando sus diferencias (Babo, Dago, Muri) al tiempo que "universaliza" sus caracteres a fin de evitar la reificación de la alteridad o su representación folclorizante.

\footnotetext{
106 Cfr. "La liberación se halla en correlación con la dominación. Venerar y anunciar a Jesucristo Liberador implica pensar y vivir la fe de Cristo a partir de un contexto sociohistórico de dominación y opresión", en: Leonardo Boff, Memorias de un teólogo de la liberación, España, Espasa, 1997, p. 50.
} 
La tendencia a recuperar los vacíos de la débil heterogeneidad uruguaya se configura en el acercamiento de la historia local con la de América Latina. Las dos novelas, sin embargo, escogen recorridos contrapuestos. ¡Bernabé, Bernabé! parte de la historia uruguaya, del origen de la nación y desde allí establece vínculos con la conquista española. Pero es en el prólogo del fícticio editor y no en el cuerpo de la novela donde se anudan las historias. La fragata de las máscaras invierte el recorrido y el espacio textual donde se articula. La novela se desarrolla en gran medida en Perú, distanciándose aquí de Benito Cereno. Las ruinas incaicas de Cajamarca y Cusco se recuperan para conectar el sometimiento esclavista con la conquista española. Desde esas ciudades latinoamericanas se establecen los vínculos con Montevideo como puerto de tráfico de esclavos.

Las novelas de De Mattos dejan traslucir una voluntad de "latinoamericanizar", es decir, de inserción firme en una historia, un imaginario y también en un arte de narrar, que pusieron en escena algunos grandes relatos de los años sesenta, tales como El Siglo de las Luces de Alejo Carpentier y Cien años de soledad de García Márquez, emblemas de sentimientos de pertenencia y de destino compartido, característicos no sólo de artistas e intelectuales sino también de la sociedad en su conjunto. Si pensamos en Uruguay, su más importante novelista, Juan Carlos Onetti, difícilmente podemos atribuir a sus textos tal proyección, salvo dentro de las fronteras rioplatenses. Un buen número de las novelas históricas de la posdictadura remiten a las grandes novelas fundadoras de la nueva narrativa latinoamericana, como si procuraran ahora colmar un vacío en su tradición literaria.

La fragata... reflexiona desde la posdictadura sobre las significaciones de las revueltas libertarias en América Latina sin clausurar su factibilidad, sosteniendo aun la pequeña utopía de la isla Mocha. Pero también las lee desde sus costos y fracasos, para finalmente 
desplazarse hacia otro espacio desde el cual articular la comprensión y cooperación entre los diversos sectores, de allí la demanda de un diálogo, de la tolerancia, de la comprensión como vías para construir "entre todos" una América Latina.

En Tomás de Mattos, la posdictadura como lugar de enunciación incluye la caja de herramientas que le provee el cristianismo para postular en La fragata... la caritas, el "amor al prójimo" como principio de entendimiento entre los ciudadanos y posibilidad del "nosotros"; le ofrece incluso el perdón para los adversarios y también una dimensión de esperanza final que tiñe sus obras. Estos valores no ahorran sin embargo la protesta y la contienda por sostener los derechos del hombre, como se percibe en las iracundas palabras de Tobías frente a la muerte de Babo e incluso en su participación en la rebelión de Túpac Amaru. Lo que intento decir es que, desde su herencia cristiana, Tomás de Mattos no se coloca en una izquierda extrema, pero tampoco clausura los vínculos de los valores cristianos con las posibilidades de transformación de la realidad. 

MUERTE DE FERNANDO BUTAZZONI

Aquellos que se acercan, desde diversas disciplinas, a analizar el problema de la memoria coinciden en señalar la importancia que, desde la década de 1980 si no antes, adquirió este tema. La preeminencia de la memoria y la inclinación por el pasado vuelcan la balanza de la temporalidad moderna debilitando su proyección hacia el futuro. El problema de la memoria parece convocarnos como signo acuciante de la actualidad; desde el psicoanálisis, la antropología, la historiografía, los estudios culturales crece el interés por auscultar las nuevas relaciones del individuo y las sociedades con el pasado y sus memorias.

Pero estos abordajes también presentan vastas diferencias según las coyunturas y políticas. El tema aparece vinculado a la industria cultural, a los mercados que venden memoria en un intento por contrarrestar los efectos de las innovaciones tecnológicas transformadoras de cualquier novedad en un objeto obsoleto. El regreso a la memoria indicaría un deseo por volver a recuperar cierta estabilidad en el anclaje en el pasado. Este deseo ha provocado el efecto de la "musealización" donde la memoria se desprende de la institución del museo para invadir nuestras vidas privadas. ${ }^{107}$ Desde otra perspectiva y como consecuencia de la desgastada lógica de la vanguardia que había entronizado lo "nuevo", el posmodernismo artístico cita el pasado ya desde una mirada lúdica o paródica para dar lugar al pastiche. Otro factor es el avance en los procesos de acumulación de memoria de la informática, acelerado y expandido a través de los CD-Rom e Internet.

107 Cfr. Andreas Huyssen, "La cultura de la memoria: medios, política, amnesia", en Revista de Critica Cultural, No. 18, junio 1999, Santiago de Chile. 
Desde una experiencia muy diferente, las cuestiones vinculadas con la memoria se actualizaron a partir del holocausto, con las erecciones de monumentos, museos, conmemoraciones, y con los análisis sobre el costado traumático de la memoria y del olvido. Pero también la memoria ha jugado un papel importante para justificar políticas fundamentalistas como, por ejemplo, en la Serbia post-comunista. ${ }^{108}$

Casi como un signo de los fines de siglo y milenio, de las múltiples caídas, la reconstrucción histórica de la memoria emerge ante su debilitamiento como lazo social en estas edades posnacionales. La disciplina historiográfica corona la pérdida del sentido de la Historia en el fin de la "novela nacional". Esta es una de las hipótesis que recorre Les lieux de mémoire de Pierre Nora en el contexto de Francia. La historia como experiencia ya no es capaz de articular pasado y futuro en una continuidad de la nación. La memoria, desacralizada, se vuelve resto que ya no se habita y la historia se ocupa no de celebrar la nación sino de estudiar sus celebraciones. ${ }^{109}$

El predominio de la memoria si en apariencia puede resultarnos un fenómeno globalizado, sólo es posible comprenderlo a partir de políticas específicas e historias locales. La obsesión por la memoria, que parece calar en todos los rincones del mundo, responde a escenarios o conflictos determinados: desde el regreso a la memoria como efecto del avance tecnológico en las sociedades posindustriales hasta los diversos usos de la memoria y el olvido en los países atravesados por la desintegración del bloque comunista, o en aquellos que han sufrido gobiernos dictatoriales. Entonces, ¿A qué nos referimos cuando hablamos de memoria y su correlato, el olvido en las posdictaduras del cono sur? ¿Cómo podemos ceñir el perfil que aquí nos interesa de estos conceptos?

\footnotetext{
108 Cfr. Tzvetan Todorov, Los abusos de la memoria, Bs. As., Editorial Paidós, 2000.

109 Nora, Pierre, Les lieux de mémoire, Gallimard, 1993.
} 
Si ahora colocamos el problema de la memoria y del olvido en el contexto de la posdictadura del cono sur, su importancia emana de la experiencia de la última dictadura y sus herencias en democracia. Ceñir y recortar sus significados implica, en primera instancia, reconocer la dimensión politica enraizada en los usos que el gobierno de la dictadura y luego el Estado democrático hicieron de la memoria y del olvido.

La memoria colectiva tiene su propia lógica, sus tiempos de construcción y consolidación, sus amnesias y transformaciones, es propiedad de una comunidad, es "espontánea" sostiene Pierre Nora. Pero en el marco de la dictadura y la posdictadura, la memoria y el olvido no son sólo operaciones de la comunidad sino, en principio, imposiciones del Estado, se "decretan" y frente a estos decretos la comunidad va a responder en diferente medida.

Podemos distinguir, en nuestro caso, dos ejes: por un lado la demanda de recuperar las "memorias del horror" para conocer en sus detalles lo ocurrido durante la última dictadura uruguaya. Por el otro, la deconstrucción de las memorias y monumentos utilizados por la dictadura. Si éstos son los reclamos de la posdictadura ¿Cómo opera la novela histórica frente a ellos? Los desplaza hacia el pasado de la historia a fin de recuperar otras memorias silenciadas y desarticular los procesos de edificación de los monumentos nacionales.

Conviene distinguir, aunque sea brevemente, la historia de la memoria. En El orden de la memoria, Le Goff aborda las memorias colectivas de los pueblos y presenta diversos momentos en que ellas se alejan o acercan a la historia, mostrando límites borrosos. Queda claro, sin embargo, que la memoria remite a las fábulas del origen, a los relatos escatológicos o de un modo más general a los imaginarios que configuran las identidades de naciones o grupos. 
Las relaciones entre memoria e historia varían de un modo continuo: corren por carriles paralelos, a veces se acercan y reafirman o bien se distancian y niegan. La historiografía lee el pasado desde el presente, distinguiendo sin embargo ambos períodos; la memoria en cambio suele desentenderse de este requisito y selecciona lo que interesa al presente, más aun: "los lugares de memoria no son eso de lo que nos acordamos, sino allí donde la memoria trabaja; no la tradición misma sino su laboratorio"."10 Dice Maurice Halbwachs: "la memoria es una corriente de pensamiento continuo, de una continuidad que nada tiene de artificial pues solo retiene del pasado lo que permanece vivo o es capaz de vivir en la conciencia del grupo que la sostiene"."11

Para Pierre Nora, la memoria colectiva difiere de la historia dado su carácter maleable y versátil, su ambigüedad siempre abierta a nuevas apropiaciones: "la memoria, en efecto, es más un marco que un contenido, un desafío siempre disponible, un conjunto de estrategias, un estar-ahí que vale menos por lo que es que por lo que se hace con él".

Yosef Yerushalmi distingue la exhaustividad de la disciplina histórica ("Para el historiador, Dios mora en los detalles") de la memoria, cuya selección suele destacar del conjunto un detalle significativo para el presente ("la memoria se subleva, denunciando que los detalles se han transformado en dioses"). Pero hacia el final de su artículo advierte contra cualquier rechazo que desde la memoria se formule a la historia y prefiere la colaboración de ambas. Este acercamiento entre memoria e historia subyace en los reclamos hechos por la memoria desde la posdictadura, así como en las propuestas de las novelas históricas. Transcribo sus conclusiones pues pueden servir para iluminar el actual contexto:

\footnotetext{
110 Nora, Pierre, Les lieux de mémoire, op. cit.

111 Citado por Héctor Schmucler en "Las exigencias de la memoria", en Punto de vista, año XXIII, n. 68, Buenos Aires, diciembre de 2000, p. 6.
} 
"Pero la dignidad esencial de la vocación histórica subsiste, e incluso me parece que su imperativo moral tiene en la actualidad más urgencia que nunca. En el mundo que hoy habitamos, ya no se trata de una cuestión de decadencia de la memoria colectiva y de declinación de la memoria colectiva, sino de la violación brutal de lo que la memoria puede todavía conservar, de la mentira deliberada por deformación de fuentes y archivos, de la invención de pasados recompuestos y míticos al servicio de los poderes en tinieblas. Contra los militantes del olvido, los traficantes de documentos, los asesinos de la memoria, contra los revisores de enciclopedias y los conspiradores del silencio, contra aquellos que, para retomar la magnífica imagen de Kundera, pueden borrar a un hombre de una fotografía para que nada quede de él con excepción de su sombrero, el historiador, el historiador solo, animado por la austera pasión de los hechos, de las pruebas, de los testimonios, que son los alimentos de su oficio, puede velar y montar guardia"..12

El acercamiento o la distancia entre historia y memoria caracteriza los dos modos básicos de esta última articulada en la posdictadura: si la memoria de los "horrores de la dictadura" precisa acercarse e identificarse con la historia a fin de conocer lo sucedido y testimoniarlo, escribir en definitiva ese tramo de la historia; por el contrario los "usos de la memoria" por parte del poder tienden a presentar una memoria alejada de los saberes de la historia, una memoria maleable y dúctil a las apropiaciones, que es necesario desmantelar desde la historia. Se trata, en definitiva, de herencias de la dictadura, cuyo gobierno operó en el secreto instalando una política del olvido, mientras saturaba la memoria pública con una serie de conmemoraciones.

También debemos señalar que si la historia se propone transcribir en sus detalles los hechos del pasado tendiendo a la exhaustividad; la

112 Yerushalmi, "Reflexiones sobre el olvido", en Usos del olvido, Bs. As., Nueva Visión, 1989, p. 25. 
memoria es una particular combinación de recuerdos y olvidos, como apunta con razón Todorov: "En primer lugar hay que recordar algo evidente: que la memoria no se opone en absoluto al olvido. Los dos términos para contrastar son la supresión (el olvido) y la conservación; la memoria es, en todo momento y necesariamente, una interacción entre ambos (...) la memoria como tal es forzosamente una selección"."13

Esta regulación entre la memoria y el olvido ha conducido en la mayoría de los casos a una reafirmación de la importancia de la memoria como constitutiva de la identidad de los pueblos y sostén para proyectarse en el futuro; en cambio otros, como Nietzsche (y Ernst Renan en su famosa conferencia "¿Qué es la nación?"), postulan la necesidad de olvido: "se trata de saber olvidar adrede, así como sabe uno acordarse adrede; es preciso que un instinto vigoroso nos advierta cuándo es necesario ver las cosas históricamente. $\mathrm{Y}$ he aquí el principio sobre el que el lector está invitado a reflexionar: el sentido no histórico y el sentido histórico son igualmente necesarios para la salud del individuo, de una nación, de una civilización"."14 Ante estas posiciones contrapuestas, Yerushalmi formula, me parece, la pregunta clave ¿dónde trazar la frontera entre el olvido y la memoria? Es clave en tanto pone en escena dos cuestiones: la ambigüedad de la memoria. Sus límites borrosos con el olvido pueden conducir a lo que Todorov llama los "abusos de la memoria", pero también en esta frontera, en esta marca que cada sector elige, podemos leer su posición política.

113 Tzvetan Todorov, Los abusos de la memoria, Bs. As., Paidós, 2000, p. 16.

114 Citado por Yerushalmi, "Reflexiones sobre el olvido", en Usos del olvido, Bs. As., Nueva Visión, 1989, p. 16. En el mismo libro Eduardo Rabossi cita la posición de Nietzsche como antítesis de las ideas de Locke, en "Algunas reflexiones... A modo de prólogo", p. 10. 


\section{Las memorias olvidadas}

Las dictaduras del cono sur no fueron ajenas a las prácticas de control y apropiación de la memoria implementadas por las políticas autoritarias de todos los tiempos. La afirmación de Todorov -"Los regímenes totalitarios del siglo $\mathrm{XX}$ han revelado la existencia de un peligro antes insospechado: la supresión de la memoria"115 -encuentra en las palabras de Le Goff su otra cara: "La conmemoración del pasado asume su culminación en la Alemania nazi y en la Italia fascista". ${ }^{16}$ El conocimiento que aportaban, por ejemplo, los prisioneros escapados de los campos de concentración del nazismo, resultaba una de las políticas más certeras en contra del régimen ("Informar al mundo sobre los campos es la mejor manera de combatirlos") ${ }^{117}$ por lo que la reconstrucción de la memoria es en este contexto un acto de oposición al poder.

El accionar de los gobiernos dictatoriales del cono sur fue, en gran medida, llevado a cabo en la clandestinidad. Dos fueron los modos en que los opositores disputaban este silencio para desbaratarlo: la circulación de información en prensas clandestinas entre los grupos afectados y la apelación a determinadas instituciones que, como la prensa internacional o las sociedades de derechos humanos, se constituían en lugares adecuados para dar a conocer los reclamos. El testimonio en uno u otro caso permitía recuperar las informaciones del operar clandestino. A diferencia de Argentina donde la "desaparición de personas" fue la modalidad preferida, en Uruguay la dictadura fue bastante menos clandestina en tanto eligió preferentemente la cárcel, de allí que se la denomine el "gran encierro". Recordemos que 127 de los 160 uruguayos

\footnotetext{
115 Tzvetan Todorov, Los abusos de la memoria, Bs. As., Paidós, 2000, p. 11.

116 Jacques Le Goff, El orden de la memoria. El tiempo como imaginario, Bs. As., Paidós Básica, 1991, p. 170.

117 Todorov, op. cit., p. 14.
} 
"desaparecidos" entre 1971 y 1981 ocurrieron en territorio argentino. Pero ello no impidió las acciones urdidas en el secreto, en especial aquellas que coordinaban las medidas entre los diversos países (el Plan Cóndor) ni un severo control ideológico (que clasificaba a cada ciudadano en tres categorías de "peligrosidad política") ni la privación ilegítima de la libertad. ${ }^{118}$

No bien iniciada la democracia se planteó en Uruguay el problema de recuperar la memoria de lo sucedido durante la dictadura. Sin embargo, una serie de eventos pautó también una voluntad de olvido. La aprobación de la "Ley de Caducidad de la Pretensión Punitiva del Estado", propuesta por el presidente constitucional Sanguinetti y aprobada por el Congreso en 1986, impidió el enjuiciamiento de los militares y policías de la represión. Posteriormente una campaña opositora propuso someter esa ley a un plebiscito popular para su anulación, pero en el referendum llevado a cabo en abril de 1989, el 54\% votó por su aprobación quizás como resultado de una de las consignas para apoyarla, que asociaba el proceso de redemocratización con la pacificación social y el olvido. El propio presidente Sanguinetti acuñó la metáfora de "los ojos en la nuca" para cancelar toda vuelta al pasado a fin de indagar las violaciones de los derechos humanos cometidas por los militares y policías.

Si el Estado institucionalizó el olvido como una medida que consideró necesaria para implementar el proceso redemocratizador, ciertos sectores del campo intelectual y literario discuten esta ecuación y ofrecen otras respuestas al complejo problema de articular la democracia con la memoria y la justicia. La apuesta por la recuperación de la memoria se articuló en tres géneros discursivos, que significaron una

118 Cfr. Fernando Reati, "Introducción", en: Memoria colectiva y politicas de olvido. Argentina y Uruguay, 1970-1990, comp. Adriana Bergero y Fernando Reati, Rosario, Beatriz Viterbo, 1997, p. 16. 
aproximación al problema muy diferente, aunque en gran medida convergente. Por un lado en los ensayos citados al comienzo se discutieron de un modo amplio las "fracturas de la memoria", la recuperación de memorias heterogéneas, la necesidad de revisar los dispositivos identitarios, etc.

Los testimonios abordaron la memoria desde un ángulo muy diferente. El testimonio vehiculiza las particularidades de la dictadura en Uruguay, por ello centran sus relatos en torno a las experiencias carcelarias: Memorias del calabozo de M. Rosenkof y E. Fernández Huidobro, Cartas desde la prisión de Raúl Sendic, Las manos en el fuego de E. González Bermejo, etc. A estas obras se suman los textos testimoniales -de índole periodística- que intentan esclarecer sucesos ocurridos durante la dictadura (Alto el fuego, de N. Caula y A. Silva; ¿Quién mató a Michelini y Gutiérrez Ruiz? de C. Trobo; El vientre del cóndor de S. Blixten, etc.). ${ }^{119}$

El auge de la novela histórica no fue ajeno a este interés, apostó incluso a la necesidad de extender la memoria a la completa historia de la nación.

Una breve comparación entre estos últimos dos géneros puede resultar útil para marcar las peculiaridades del trabajo con la memoria de la novela histórica. El testimonio despliega una memoria inmediata, reciente, de corto alcance, centrada en la última dictadura. La memoria es aquí parte de la experiencia vivida por el testigo, es una memoria individual, con un fuerte anclaje en el sujeto y sus padecimientos. En ciertos casos el relato se asienta en los actos mínimos de cada día, en una inédita cotidianeidad vivida en las cárceles, en las sesiones de tortura, en

119 Para el tema del testimonio carcelario, Cfr. Fernando Reati, "De falsas culpas y confesiones: avatares de la memoria en los testimonios carcelarios de la guerra sucia", en: Memoria colectiva y politicas de olvido. Argentina y Uruguay, 1970-1990, op. cit. 
la necesidad de acudir al baño, en el acto de comer y dormir, en los traslados, en las descripciones de las cárceles y los guardias, y también en las esperanzas y expectativas de las víctimas.

Las características particulares de la novela histórica como género imprimen su propio giro al modo de abordar la memoria. En principio se instala en un pasado más remoto. La experiencia de la dictadura requirió no sólo la reconstrucción de la memoria inmediata, su aliento fue mucho mayor e indagó en el pasado las memorias olvidadas, que permiten ahora reflexionar o explicar la nueva emergencia de la violencia estatal. Por un lado procuran acercar la memoria del pasado a la historia escudriñando en sus archivos y siguiendo de cerca los datos históricos, casi en un intento por usurpar el lugar del historiador; pero por otro lado, narran la historia desde la literatura, sus concepciones estéticas y sus procedimientos dirigen el trabajo con la referencia. Seleccionan y descartan eventos, fíccionalizan escenas y personajes, introducen la mirada en los escenarios interiores y operan sobre las memorias comunitarias, los imaginarios, las fábulas del origen y los relatos escatológicos.

¿Cuáles son las operaciones que estas novelas llevan a cabo sobre la memoria? Con notable insistencia la puesta en escena de la memoria se articula, en ellas, con la historia del siglo XIX. Frente a una perspectiva hegemónica, estas relecturas del pasado indagan zonas ocultas, relatos olvidados, versiones que rescatan otras memorias e incluso aquellas que, si forman parte de la historia oficial, ahora requieren reescribirse desde la nueva óptica que ofrece la posdictadura. Constituyen, de un modo general, las "memorias de la barbarie". No sólo procuran restaurar las memorias otras, critican las políticas de la censura, en especial el "secreto" de Estado como modo de ocultamiento. 
¿Qué significaciones puede adquirir recuperar las memorias del pasado? ¿Cuándo se trata de posiciones conservadoras sustentadoras del status quo, o cuándo se vuelven reformadoras o revolucionarias o, más difícil aún, se sostienen en la ambigüedad?

Desplazar los problemas del presente hacia el pasado bien puede constituirse en una postura compleja y ambivalente. Todorov señala como uno de los abusos desviantes de la memoria el riesgo de quedar atrapados en el pasado ("Otra razón para preocuparse por el pasado es que ello nos permite desentendernos del presente, procurándonos además, los beneficios de la buena conciencia"), coincidiendo con la afirmación de Éric Conan y Henry Rousso: "A falta de emprender una acción real contra el "fascismo" actual, sea real o fantasmagórico, el ataque se dirige resueltamente contra el fascismo de ayer" (53). A partir de procedimientos diversos, las novelas históricas de la posdictadura intentan sortear este riesgo acentuando los vínculos de ese pasado con el presente. Ya vimos cómo el juego entre diferentes narradores (Josefina y el editor MMR) instalados en distintos tiempos le permite a Tomás de Mattos remitir al presente de su propia escritura; en algunas novelas, el autor mismo declara en su prólogo esta voluntad de un modo directo.

Otra de las posibilidades radica en buscar en el pasado una "astilla" recuperable en el presente para completar la tarea revolucionaria como quería Benjamin en sus Tesis de la filosofia de la Historia: "El pasado lleva consigo un índice temporal mediante el cual queda remitido a la redención. Existe una cita secreta entre las generaciones que fueron y la nuestra. Y como cada generación que vivió antes que nosotros, nos ha sido dada una flaca fuerza mesiánica sobre la que el pasado exige derechos". ${ }^{20}$ El ciclo de novelas de Eduardo Acevedo Díaz destaca el valor revolucionario de la memoria de la independencia para, como

120 Walter Benjamin, "Tesis de la filosofía de la historia", en: Discursos interrumpidos I, Bs. As. Taurus, 1989, p. 178. 
vimos, legitimar su participación en las revueltas de Timoteo Aparicio y Aparicio Saravia.

En el polo opuesto encontramos la "conmemoración" como una vía para citar el pasado como un acto de clausura. "La Leyenda Patria" (1879) de Zorrilla de San Martín puede servirnos como contraejemplo del caso de Acevedo Díaz, pues si bien se refiere a la memoria revolucionaria, suprime tanto la multivocidad como la potencia de la memoria, cristalizada en el rotundo y simplificador "Todo acabó", el verso que cierra el poema y marca la diferencia irreductible entre pasado y presente para hacer del pasado un "culto" que inmoviliza a sus héroes. Tan lejos de un poema como "Los héroes de mármol" de José Martí donde la memoria eclosiona en violencia cuando se invoca a los héroes a la acción: "Saltan los hombre de mármol". ${ }^{21}$

Las novelas históricas de la posdictadura no parecen responder a estas operaciones sobre el pasado, no fraguan ni una memoria revolucionaria ni una conmemoración conservadora de los monumentos nacionales. La recuperación de la memoria tiene que ver con el desplazamiento de la agenda de la memoria posdictatorial hacia el pasado. Veamos entonces primero esta agenda.

La memoria se vincula con dos cuestiones: por un lado, la necesidad de clarificar lo ocurrido durante la dictadura, de escribir ese trayecto histórico que aún no alcanzó una forma definitiva a fin de evaluar sus múltiples dimensiones. Existe el imperativo de arribar a la "verdad" entendida como una deuda con las víctimas, a un conocimiento detallado incluso para encontrar su paradero y poder realizar el duelo. La memoria se articula estrechamente con la justicia. Al respecto dice Yerushalmi: "¿Es posible que el antónimo de "olvido" no sea "la

121 José Martí, poema XLV, en: Versos sencillos, Poesía completa, Ed. Letras cubanas siglo XXI, La Habana, 1985, p. 282. 
memoria" sino la justicia?". ${ }^{22}$ La posdictadura pone en escena el conflicto entre la voluntad de juzgar a los responsables y el esfuerzo por amnistiarlos y ambos significan contrarias perspectivas frente a la memoria. Fernando Reati recuerda, con una cita de Peter Burke, que la palabra "amnesia" está etimológicamente emparentada con la palabra "amnistía", y "que ésta última significa un acto de olvido voluntario a la vez que un borramiento oficial de la memoria". ${ }^{123}$

Pero también la memoria en la posdictadura se relaciona con los procesos identitarios como un componente esencial para la configuración de identidades comunitarias o nacionales. En esta línea la experiencia de la última dictadura es percibida desde dos metáforas: el "trauma" que se vierte desde la psique del individuo a la psique social, y las "fracturas de la memoria" que atraviesan y escinden a la sociedad.

La memoria aparece como un proceso traumático que hiere los ideales fundacionales de la sociedad uruguaya. La imposibilidad de narrar lo sucedido mantiene a la memoria soterrada y a la vez latente en el síntoma y propende a la "repetición", en este caso, de las experiencias de políticas violentas y autoritarias. En cambio la recuperación de la memoria del horror permite elaborar a través de las palabras lo sucedido, seguir los mecanismos del duelo. La memoria posibilita a la vez reintegrar algo como perdido e irrecuperable y trasladarlo a otra dimensión, conectarlo con otros hechos, proyectarlo hacia el futuro. La amnesia no es, en esta metáfora, sólo olvido, mantiene el recuerdo reprimido en el síntoma capaz de reactualizarse y repetirse. Dice Hugo Vezzetti: "he aquí las paradojas de la "represión": lo que es amnesia y desconexión de sentido en un nivel, resulta ser, por el contrario, un

122 Yerushalmi, op. cit. p. 26.

123 Fernando Reati, "Introducción", en: Memoria colectiva y politicas de olvido. Argentina y Uruguay, 1970-1990, comp. De Adriana Bergero y Fernando Reati, Rosario, Beatriz Viterbo, 1997, p. 11. 
"recuerdo" tan intenso que es como si el suceso estuviera siendo todavía vivido, sin mediaciones ni tiempo transcurrido". ${ }^{124}$ En la posdictadura los carriles viables para recuperar la memoria van desde la justicia hasta las prácticas políticas, intelectuales y artísticas. Pero las novelas históricas van a desplazar esta metáfora del trauma y sus consecuencias, al pasado de la historia donde justamente la memoria no ha sido tramitada.

Para Hugo Vezzetti este camino terapéutico tendiente a elaborar el trauma de la memoria a fin de proyectar el futuro sin fantasmas, resulta una tercer alternativa que descarta dos anteriores: "En el punto de partida está la necesidad de separarse de dos formas de negación de la tragedia: la que propone "dar vuelta la página" o la que pretende retomar el combate en la misma escena congelada. En un caso se pretende que ese pasado está manifiestamente ausente y cancelado, a contrapelo de los signos que lo reactualizan; en el otro, en la visión heroica de los militantes y los fusiles caídos que aguardan ser nuevamente empuñados, el pasado queda borrado por una operación simétrica: está tan plenamente presente que no hay propiamente un pasado que rememorar". ${ }^{125}$ Aquí me interesa postular el modo en que la memoria se vuelve en la posdictadura un índice para definir no sólo políticas estatales sino además posicionamientos políticos de los diversos grupos. Ya que la memoria en su dimensión social no se resuelve en el diván, requiere una praxis política e intelectual que incumbe a los gobiernos, la justicia, la prensa, los reclamos y protestas de diversas agrupaciones, intelectuales y artistas, en suma a los ciudadanos. Se trataría de integrar la memoria a la esfera pública o en términos de Habermas instaurar el "uso público de la historia" mediante su continua interrogación e interpretación.

\footnotetext{
124 Hugo Vezzetti, "Variaciones sobre la memoria", en Punto de vista No 56, Año XIX, diciembre de 1996, Bs. As., p. 3.

125 Hugo Vezzetti, op. cit., p. 2.
} 
De un modo muy concreto la memoria, dijimos, se vincula con la justicia; los indultos y políticas del olvido impiden en última instancia la organización de las recientes democracias a partir del respeto de los derechos humanos (la amnistía traduce políticamente la amnesia). El avance de la impunidad supone un retroceso tanto en la memoria como en la democracia, como deja ver el siguiente párrafo de José María Gómez: "la cuestión de los derechos humanos puede ser comprendida al mismo tiempo como memoria y como telos, como recuerdo histórico del acontecimiento destructor (que no se debe olvidar, por deuda moral contraída con las víctimas y para que no se repita) y como promesa del ideal regulador de una ciudadanía utópica en un espacio social democrático". ${ }^{126}$ En este marco resurge la idea de lo siniestro para señalar la igualación de víctimas y victimarios propiciada por las leyes que sancionaron la impunidad.

Además, la memoria se proyecta claramente en el futuro, en el doble sentido de impedir la repetición de la barbarie y organizar la democracia, mediante el vínculo estrecho que señala Mariana Pianca: "Siempre que hablamos del olvido, nuestra mente, como la cabeza de Janus, se vuelve hacia atrás. Sin embargo, astutamente la política del olvido no nos interpela sólo a olvidar lo que quedó atrás, también nos invita a dejar atrás lo por venir (...) Y para la salud de individuos y nación, es tan importante el recuerdo no amputado del pasado, como la memoria no amputada del futuro. El retorno de lo reprimido -el retorno del horror- en este sentido, estaría asegurado tanto por un pasado silenciado como por un futuro olvidado en un presente sin alternativas". ${ }^{127}$

126 José María Gómez, "Eclipse de la memoria, política del olvido: la cuestión de los derechos humanos en una democracia no consolidada", en Punto de vista, No. 36, Año XII, diciembre de 1989, Bs. As.

127 Mariana Pianca, "La política de la dislocación (o el retorno de la memoria del futuro), en: Memoria colectiva y politicas de olvido. Argentina y Uruguay, 1970-1990, op. cit. 
"Las fracturas de la memoria" es otra de las imágenes que el psicoanálisis aporta para describir uno de los más importantes efectos de la experiencia de la dictadura sobre la memoria colectiva como dispositivo identitario. Fueron Maren y Marcelo Viñar quienes en Uruguay acuñaron el sintagma para explicar la escisión del cuerpo social, originada por la política dictatorial que negaba la alteridad del "subversivo" con la imposición de un discurso que separaba y condenaba al otro como enemigo, extraño, opositor: "Fracturas de la memoria y pérdida de la capacidad para admitir la alteridad. Lo heterogéneo como insoportable, como contraste a la riqueza del diálogo controversial, definitorio del ser humano. Este es uno de los legados de la dictadura que más nos inquieta e interroga: la herencia perversa de aspirar a un saber unívoco y monolítico en el que la divergencia es percibida como detestable y el interlocutor se vuelve abominable y abusivamente un otro, extraño o enemigo". ${ }^{28}$

La escisión de la sociedad entre amigos y enemigos fue una de las herencias recogidas entre sus pacientes que calan en la posdictadura impidiendo la formulación de un proyecto colectivo, la asunción de nuevos mitos o ideales comunes:

"Proponemos pensar que frente a la experiencia de terror, la sociedad uruguaya está escindida en dos actitudes irreconciliables: para unos la vida siguió y el terror fue un detalle en el curso de la historia; para otros, fue una convulsión que rompió la continuidad de sus destinos y los obligó a cicatrizar heridas a veces irreparables. Proponemos pensar que esta fragmentación de la memoria y del proyecto colectivo inaugura -por la vía del horror y la violencia- un mecanismo disociativo que corroe y corrompe el lazo social. El origen traumático y violento de esta fragmentación sería la razón de su persistencia, es decir, que, aunque cese

128 Maren y Marcelo Viñar, Fracturas de memoria. Crónicas para una memoria por venir, Montevideo, Trilce, 1993, p. 13. 
la causa no cesan los efectos: ruptura de pactos y alianzas transubjetivas, que tejen y sostienen los lazos sociales y aportan, en una lógica freudiana, los factores de cohesión grupal y comunitaria" (125).

Esta ruptura de los lazos sociales, esta imposibilidad de reanudarlos en proyectos colectivos es uno de los ejes retomados por las novelas históricas para indagar en el pasado las luchas fratricidas. La imagen del fratricidio (el mito de Abel y Caín, la figura de Antígona y sus hermanos, la crucifixión de Cristo) marca no sólo el enfrentamiento entre hermanos, señala también la incapacidad para integrar la alteridad. Abel -como el Cristo negro Babo- se vuelve un indígena charrúa o un negro esclavo. Maren y Marcelo Viñar proponen el "diálogo controversial" como vía para considerar esa memoria plural y heterogénea e incluir a los diversos sectores, en la búsqueda de un consenso.

¿Cuál es la índole de las memorias que interesan a estas novelas? ¿Cómo podemos distinguirlas?

Antes que nada quiero destacar la recurrente comparación de las dictaduras del cono sur con el holocausto en los artículos sobre memoria publicados en varias revistas, en especial Punto de vista. Sin duda confrontar las similitudes y diferencias entre ambos terrorismos de estado siempre resulta iluminador. Pero me inquieta no advertir en primer lugar una aproximación crítica a la hegemonía del holocausto como "modelo" al cual siempre se acude, cuando los genocidios se han sucedido a lo largo del mundo. Por otro lado, no se advierte una indagación ni nacional ni latinoamericana sobre el tema. Por momentos la "ejemplaridad" del holocausto ¿no estará abortando una mirada a las propias políticas que en América Latina y en el cono sur bien pueden ser comparadas con el que muchos consideran un genocidio perpetrado por los estados terroristas?. Sin descartar los vínculos con el holocausto ¿no sería más conveniente mirar desde la posdictadura nuestro pasado, cuyo origen ya nos enfrenta 
con políticas que condujeron a la destrucción de gran número de indígenas en la Conquista y en las posteriores "Campañas del Desierto? Las novelas históricas uruguayas reponen esta revisión del pasado a partir del presente recuperando diversos tipos de memorias.

Las memorias de la alteridad son las que recupera Tomás de Mattos en sus novelas. Son quizás las memorias que de un modo más brutal ponen en escena el autoritarismo de las políticas estatales: el genocidio charrúa en Uruguay y la esclavitud en América Latina. Son, sin embargo las que más se distancian del presente. No apuntan, no pueden, de un modo directo a incluir o volver a incluir a estos sectores en la nación. Establecen una relación más oblicua con el presente aún en el caso en que incorporen deliberadamente, como ¡Bernabé, Bernabé!, temas prioritarios de la posdictadura. Por ello se puede hablar, como lo hace Teresa Porzecanski, de memorias ausentes sólo restituibles simbólicamente.

Otro grupo lo constituyen las memorias de la barbarie civilizatoria: representan a aquellos grupos que sufrieron represalias o fueron víctimas de regímenes autoritarios que se autolegitimaban en un discurso fundado en las ideas de progreso, modernización, civilización o Doctrina de la Seguridad Nacional. También el exterminio de los charrúas se sustentó en discursos contra la "barbarie", pero a diferencia de ellos, estas víctimas no se encuentran fuera de la nación, sólo han sido opositores y adversarios de algún sistema represivo. Estas memorias pueden asociarse de un modo más directo con lo sucedido durante la última dictadura.

En ambos casos se trata de contramemorias, es obvio decirlo, porque cuestionan los relatos hegemónicos y ponen al descubierto la duplicidad de sus discursos legitimantes. 


\section{Los usos de la memoria}

Por un lado, la dictadura y la posdictadura sancionaron el olvido a través de diferentes medidas pero, a su vez, la primera desplegó toda una estrategia simbólica para apropiarse de la memoria, respaldada en una serie de tópicos nacionalistas que hicieron del término "oriental" la síntesis de su defensa patriótica. ${ }^{129}$ Bordaberry decretó a 1975 el "Año de la Orientalidad", como conmemoración del Sesquicentenario del desembarco en la Agraciada, repatrió, además, los restos de Latorre y envió a construir el mausoleo de Artigas. La escena pública se saturó de monumentos como un modo de reinstalar los lazos, previamente abolidos, de la comunidad y como un medio de legitimación del gobierno. Como veremos más adelante, varias novelas se ocupan de desarmar tales "monumentos".

Conviene, por todo esto, hablar de los "usos" de la memoria y el olvido pues ambos están atravesados por una fuerte carga política, en cuanto resultan una operación emanada del estado e impuesta por decreto a la sociedad. ${ }^{130}$ Este es el fondo sobre el cual debemos colocar los valores que ambos términos adquieren en las novelas históricas. Si el estado dictatorial desplegó una parafernalia patriótica y el gobierno democrático institucionalizó el olvido como una medida para recomponer el cuerpo social, las novelas históricas discuten estas ecuaciones y ofrecen otras respuestas al complejo problema de articular la democracia con la memoria y la justicia.

Es evidente que en este caso la índole de la memoria sancionada por el gobierno de la dictadura difiere ostensiblemente del valor de la "memoria" sobre lo ocurrido durante la última dictadura. En este caso se

129 Cfr. Cosse, I. y Markarian, V., 1975: Año de la Orientalidad, Trilce, Montevideo, 1996.

130 Cfr. AAVV, Usos del olvido, Ed. Nueva Visión, Bs. As., 1989 
trata de los usos de la memoria por parte del poder, sea éste dictatorial como las apropiaciones de Artigas, Lavalleja y Latorre o aquellas sancionadas en el pasado por la dirigencia política. El espesor y calidad difieren, pues aquí estamos más cerca de los "lugares de la memoria" -definidos por Pierre Nora- como esa masa dúctil a la manipulación, cuyos monumentos se ofrecen como "precipitados químicamente puros". No obstante, el acercamiento -un tanto conservador- de su monumental obra a los lugares de memoria franceses, difiere ostensiblemente del que se propone la posdictadura. Mientras Nora indaga los monumentos nacionales para recuperar una "identidad que hoy se volvió dudosa" y cuya justificación radica "en la emoción que despierta todavía en cada uno de nosotros un resto de identificación vivida con estos símbolos en parte borrados", la posdictadura lo hace para socavar las herencias de una identidad desmentida por las políticas de violencia. E1 monumento no es entonces el espacio para acceder a los valores nacionales sino el punto de partida para revisarlos.

Las conceptualizaciones de Jacques Le Goff sobre el monumento resultan más adecuadas para acercarnos al análisis de las novelas históricas. En El orden de la memoria, Le Goff describe (una verdadera "revolución" dentro de la historiografía) la asimilación del documento al monumento para destacar la operación crítica frente a ambos. ${ }^{131}$ Mientras el positivismo indagaba la autenticidad del documento como texto fiable, la nueva perspectiva critica al documento en tanto él mismo es un monumento. Se propone su desmontaje a través del análisis de sus condiciones de producción:

"El documento no es inocuo. Es el resultado ante todo de un montaje, consciente o inconsciente, de la historia, de la época, de la sociedad que lo ha producido, pero también de las épocas ulteriores durante las cuales ha continuado viviendo, acaso olvidado, durante las

131 Cfr. "Documento/Monumento", en op. cit. 
cuales ha continuado siendo manipulado, a pesar del silencio (...) no existe un documento-verdad. Todo documento es mentira (...) es un montaje. Es preciso ante todo desmontar, demoler ese montaje, desestructurar esa construcción y analizar las condiciones en las que han sido producidos esos documentos-monumentos".

De un modo similar, las novelas históricas de la posdictadura se ocupan de desarmar los monumentos oficiales, mostrando los hilos del poder. Aquellos construidos por la última dictadura, más allá incluso de constituir imposiciones a la memoria, tienen otro efecto, el de confundir la historia mediante vínculos ficticios. Evidentemente las elecciones apelaban a los valores de la nación como en el caso de Artigas y Los Treinta y Tres Orientales, pero allí se colaba la figura de Latorre portadora de valores militares. Esta política que confunde, mezcla y une desconociendo las diferencias marcadas por la historia, se sostiene en el olvido de las disparidades entre los tres personajes.

Durante el gobierno de Menem en la Argentina tuvo lugar una apropiación similar de la memoria que dio lugar a un amplio debate en la revista Punto de vista (número 36, diciembre de 1989). En 1989 el presidente Menem firmó los decretos de Indulto que beneficiaron a los jefes militares acusados de violar los derechos humanos durante el período dictatorial, en nombre de la reconciliación y pacificación nacional. Esta política del olvido intentó ser contrarrestada -o mejor afirmada- por la repatriación de los restos de Juan Manuel de Rosas y la aparición en las pantallas de la televisión de la figura de éste junto a la de Sarmiento con una paloma de la paz entre ambas. Tal flagrante distorsión actuaba como base de una propaganda que también se valía de argumentos de pacificación y reconciliación nacional. Resulta paradigmático este doble gesto de decretar el indulto a los jefes militares y al mismo tiempo recuperar dos figuras históricas francamente disímiles. 
Tanto Hilda Sábato como Beatriz Sarlo concluyen atribuyendo a ambas acciones el valor del olvido. En principio se trata de una tergiversación de la historia que tiende a una reconciliación donde no la hubo, confusión sólo posible por el previo paso de olvidar los diversos proyectos y las opuestas políticas de Rosas y Sarmiento. La cita memoriosa -dice Hilda Sábato- se recubre de una densa capa de olvido:

" 'Saber olvidar es también tener memoria'. Con esta cita de Hernández, el presidente Menem nos incita a construir una historia apoyada en el olvido. No se trata solamente de abandonar los mitos creados por los relatos congelados de las dos versiones dominantes de la historia argentina, sino sobre todo de olvidar, de enterrar las memorias de los conflictos y las diferencias, de clausurar. El gesto de revivir a Rosas o a Sarmiento se realiza paradójicamente para enterrarlos de manera definitiva en el panteón de la síntesis nacional. Como se pretende sellar el pasado más reciente cuando se firman los decretos de indulto." (10)

Y Beatriz Sarlo añade:

"E1 reciente indulto a los responsables de crímenes aberrantes es considerado por quien lo otorgara como un tributo a la reconciliación nacional; las frases banales ("dar vuelta una página", "reconciliarse para reconstruir el futuro", "pacificar") expresan el proyecto utópico de la igualación en el olvido; la operación incluyó a la historia reciente y, también, a la del siglo pasado; mientras el cura Ezcurra proponía a Rosas como modelo de la juventud, se preparaban los decretos del indulto; en ambos casos se proponía olvidar: quién fue Rosas, quién fue Sarmiento, quienes fueron los Libres del Sur, quienes son los militares y los montoneros, quienes fueron las víctimas y los sobrevivientes; sólo olvidando, efectivamente, esa reconciliación de panteones es posible; sin olvido, el carnaval histórico que se nos propone es impracticable." (13) 
Las dos operaciones -las políticas del olvido y las políticas de la memoria que igualmente se fundan en el olvido- reclaman el aporte de la historia para restituir la memoria. Las novelas históricas revisan archivos y documentos de la mano de un énfasis histórico, pero también se abren a la dimensión ficcional para reescribir los puntos ciegos de la historia, para reintegrar desde el detalle de la vida privada los avatares ignorados por ella, para elaborar traumáticos y dolorosos conflictos del pasado o para saldar simbólicamente la deuda con víctimas de la violencia.

\section{El principe de la muerte de Fernando Butazzoni}

El príncipe de la muerte ${ }^{132}$ articula estos temas en múltiples dimensiones: los usos del olvido como prácticas de los regímenes -autoritarios o no- que hacen del "secreto" una razón de estado; los vínculos del "secreto" con la locura; el trauma generado por el olvido y su lógica asentada en la "repetición"; la reescritura e indagación de la violencia como una terapia del cuerpo nacional; la recuperación de las memorias para revisar la identidad uruguaya.

El olvido como práctica de gobierno hace del secreto un modo de la política, oculta en el anonimato de sus sicarios, borra las pruebas y presenta a la sociedad -y a la historia- una versión purificada de su gestión. Como sabemos, las últimas dictaduras del cono sur -y en especial en la Argentina- abusaron de esta práctica, pero esta novela de Butazzoni se vuelve al pasado para incluirla como característica de las sociedades y de los gobiernos rioplatenses. Publicada en 1993, retorna a las décadas finales del siglo XIX para advertir sobre los olvidos de una historia signada por la violencia de Estado, para volver a recuperar una historia sórdida y negada, cuya final repetición apunta a la última dictadura.

132 Las citas corresponden a la siguiente edición: Fernando Butazzoni, El príncipe de la muerte, Montevideo, Graffiti, 1993. 
El texto narra la imposibilidad de la desmemoria en la historia personal de Montenegro. Los sucesos y peripecias por los que atraviesa el protagonista se ordenan en tres grandes capítulos, tres momentos claves de su vida, tres intentos por deshacerse de los recuerdos y tres fracasos ante el olvido.

"El mal de la vida", el primer capítulo, cuenta la historia de los padres y ancestros de Montenegro, sitúa su origen en una genealogía. Montenegro, hijo de Albertine y del capitán al servicio de la Corte lusitana en Río de Janeiro, Rodrigo de Montenegro, nace horas antes de que sus padres sean asesinados en castigo por su romántica huida. Es recogido por la familia Aguirre, desconoce las señas de sus padres e inicia la búsqueda de su identidad a lo largo de toda la novela.

Sus aventuras comienzan en Génova, en 1843, a donde es enviado por los sectores unitarios en una misión secreta que intenta derrocar a Rosas. Logra entrevistarse con el contacto francés, Pomerin, y recibir parte de una suma pactada. Antes del nuevo encuentro, Pomerin es asesinado por oscuros poderes, hecho que obliga a Montenegro, por el temor de ser inculpado, a escapar a Barcelona. Allí descubre que dos andaluces lo buscan para asesinarlo contando para identificarlo con la seña del medallón que heredó de su madre. Entre los papeles de los andaluces se encuentra uno con la misma leyenda inscripta en su medallón: "Gutta cavat lapidem" (cuya versión completa "Gutta cavat lapidem non vi sed saepe cadendo" es: "la gota horada la piedra no por la fuerza sino cayendo a menudo"). Este hallazgo lo remite a su propio pasado y lo impulsa a investigar su estirpe. El lema sintetiza la idea de "repetición" de historias que por ocultas y silenciadas -reprimidas- siguen operando en su vida personal y en la historia.

Si la identidad personal -y por metonimia, la nacional- se construye, en parte, a través de la herencia, los ancestros, entonces en su 
madre Albertine, traída al Brasil para ocultarla a las miradas de la corte de Lisboa, se despliega el pasado, a la vez truculento y secreto, de la Casa de los Habsburgo, de la cual ella es hija bastarda:

"Sofía (...) le habló de la tía Juana, la reina enloquecida que se casó con un primo llegado de Schönbrunn y de las intrigas que alimentaban los correveidiles de Dietrichstein y del cruel asesinato de una baronesa en la propia catedral de San Esteban, fantaseaba Sofía, le narraba las rencillas del Imperio, los casamientos forzados, los hijos enfermos y los príncipes inútiles y los pastelillos envenenados con que pretendieron matar al enviado del Altísimo, los ominosos cadalsos (...) toda Europa plagada de reinos envilecidos (...) marcados a fuego por la corrupción y el adulterio y los lazos de sangre que tornaba a sí misma para crear enfermedades tan nobles como repugnantes" (25).

En esta cita podemos leer una de las metáforas subyacentes en la novela: la imbricación entre secreto y locura. Montenegro procura ignorar y deshacerse de ese pasado donde la locura -resultado de políticas urdidas en el secreto- desbastaba las vidas privadas de las familias reinantes. Pero finalmente la locura se desplaza a su propia vida privada, cuando su compañera Trini -incapaz de soportar el peso de las memorias aberrantes de Montenegro- enloquece atrapada por el ritual exculpatorio de lavar las ropas de las víctimas.

Si las políticas urdidas en el secreto terminan por enfermar a la sociedad; en la escritura de las memorias reside un poder terapéutico. La palabra "mal" se reitera en los tres títulos de los capítulos y alcanza toda su densidad significativa en lo "mal-dito" (sic): lo no dicho, lo ocultado por la historia. La curación del mal no se lleva a cabo en el interior de la novela, se realiza o intenta realizarse con la escritura del texto, con la narración (lo dicho) de las historias sórdidas que los gobiernos ocultaban en la figura de Montenegro (el mal). En esta ecuación se percibe la lógica 
del trauma que anteriormente mencionamos. El príncipe de la muerte se presenta como un espacio para elaborar los legados traumáticos, las memorias reprimidas, a partir el valor terapéutico que le concede a la escritura en su capacidad para organizarse como relato, tramitar la violencia, decir lo mal-dito.

El pasado de Albertine se conservaba en el medallón que le entregara su tía moribunda y en él Montenegro descubre una vía de acceso a su identidad, si bien lo marca como la víctima perseguida por los andaluces. Opta entonces por deshacerse de ambos y arroja el medallón a las aguas del mar en las que antes fueron arrojados sus perseguidores. Luego decide partir para Cuba: "ya no había regreso ni memoria, no quedaba nada que no fuera su propio presente (...) él sabía que al marcharse no quedaría sitio alguno para las palabras, para el pasado, para la caprichosa memoria que volvía, se tornaba mortaja, palabras, todo quedaba atrás, en la estela, en el surco leve, en el rastro inútil que el navío abriría en el mar, todo sería olvido..." (153). Esta escena cierra el primer capítulo con el gesto de negar la memoria de un pasado que puede acercarlo a su propia identidad.

Desde ahora el protagonista intenta diseñar su destino a partir del rechazo de pertenencia a sus antepasados y de la ruptura de todo rastro de la memoria: "Le tenía miedo a la memoria. Le huía como a la peste (...) le dolían los recuerdos que eran esos dolores del alma que lo traspasaban en las noches de la pensión, era una brasa ardiente la que llevaba colgada de su cuello en un medallón de oro" (115).

En el segundo capítulo, "El mal del amor", el fracaso de su romance con Inés de Alarcón sirve como motivo para insistir nuevamente en el olvido. La escena final se cierra con las llamas del incendio ordenado a la finca de su amante por Montenegro: "aunque no hubiera más rastro, acaso, que su propia y desgraciada memoria vagando por los 
corredores, oculta en los dormitorios, acechante tras las puertas, desgranándose en los jardines su memoria del amor; entonces el fuego terminaría de una vez y para siempre con esa memoria que vagaba, que se escondía, que acechaba, que sin consuelo se desgranaba hora tras hora y día tras día". (277-278)

En Barcelona Montenegro pone en práctica el "pacto secreto" para liberarse tanto de los dos andaluces como, posteriormente, de los tres hermanos que acosan a Florit, quien lo contrata para este fin. Por este medio paga a ciertos rufianes para realizar los crímenes. Montenegro elige este método por sus garantías y seguridades, pero ignora que sólo está reiterando, repitiendo otras políticas urdidas en el secreto: "soñaba con sus tratos secretos, con sus pactos recientes, con los anteriores, con algún ignoto pacto secreto del que ni siquiera tenía memoria, un pacto secreto significaba algo, un ámbito, por ejemplo, un impenetrable ámbito de confianza y silencio, un sitio en donde no cabía la duda, ni la sospecha ni el recelo podían habitar allí" (144).

Un pacto secreto es, también, un modo de gestar la historia, una historia oculta e impune -"un pacto era el sitio que significaba el silencio y la confianza en el impenetrable habitáculo" (144). Sin embargo las palabras dichas por los andaluces en el recinto secreto de la tortura ingresan a la vida de Montenegro, señalan aspectos hasta entonces ocultos de una historia que recorta su identidad, lo convocan con un pasado desconocido y ahora descubierto: "Las palabras que los dos andaluces, soñaba Montenegro, dijeron para el ruin auditorio de verdugos, ahora lo buscaban a él hasta encontrarlo y entonces lo envolvían, entonces lo amortajaban sin tregua ni piedad" (145). La víctima de Montenegro cae en el abismo de la tortura y la muerte pero arrastra al propio victimario, le señala su propia identidad cifrada en otros pactos realizados por la historia, le descubre una trama hecha de acuerdos secretos, crímenes y traiciones que, antes ocultos, ahora se revelan y lo 
acosan. Montenegro resulta un engranaje más de una historia llena de incertidumbres y dudas que desbarata la eficacia del secreto: "Lo buscaban porque ese medallón lo marcaba a fuego en una historia que no le pertenecía, que nadie le había contado, que siempre le ocultaron los que, quizás, llegaron a conocerla. Una historia tan oscura como esa mortaja de palabras, una historia llena de secretos y de pactos y de dudas y de sospechas "(146).

De un modo obsesivo esta novela trabaja la idea de "repetición" de la historia como efecto de la memoria latente. Y no se trata sólo de la reaparición de la historia de los Habsburgo; los crímenes que Montenegro ordenó regresan para convocarlo: "No había inocencia ni virtud, y las palabras volvían para decir lo que estaba oculto (...) caía la carreta en el abismo de Guerri y él sentía, en la noche de su mortaja, que no era excesiva la distancia que lo separaba de ese despeñadero, de esa caída, de la brevísima agonía de esos tres cuerpos" (147).

Todas las historias que la novela convoca se despliegan en el secreto: la experiencia amorosa de Montenegro, su tráfico de armas en Cuba y las políticas implementadas por los gobiernos del Río de la Plata que lo contratan como criminal. Sin embargo, cada nueva muerte congrega a las anteriores, construye la memoria; luego de la agonía del esclavo Juan Bermúdez, Montenegro "volvió a sentir la mirada del negro en el último momento, la mirada arrancada por el impacto de bala, la mirada hundida en las aguas turbulentas del río, viejas sombras llegaban, sombras de otro tiempo, otras aguas, parpadeó Montenegro, sintió una punzante aguja en su estómago, viejas sombras que regresaban desde otras profundidades, se pasó la mano por el rostro todavía incrédulo de que esas memorias volvieran, alguien le había dicho alguna vez que los muertos resultaban mucho más difíciles de olvidar que los vivos" (207). 
La novela cuestiona todo un modo de perpetrar los hechos -y plasmar la historia- en el anonimato, a través de los "pactos secretos", con la agencia de matones. En momentos en que el Estado, tanto en Argentina como en Uruguay, procuraba sentar las bases de su modernidad a través de un discurso civilizatorio capaz de legitimar su lucha contra la barbarie, la novela expone una organización secreta de sicarios encargados de los crímenes "necesarios" para asegurar el progreso. Narrar esta otra historia significa para Butazzoni leer a contrapelo el discurso de la civilización, descubrir la locura en la razón de Estado.

En "El mal de la muerte", el capítulo final, Montenegro regresa al Río de la Plata y se pone al servicio de Sarmiento y Mitre, como matón a sueldo, haciendo de la historia secreta el otro lado de la trama del discurso civilizatorio.

La negación de su identidad, como vimos, es constante en Montenegro. En Barcelona se desprende del medallón de su madre, sueña la muerte de su padre adoptivo Lucas Aguirre, en Cuba quema los recuerdos de su amor por Inés. Estos aspectos de su vida privada se proyectan a sus convicciones y a sus actos destructores, evidentes en sus crímenes en el anonimato, en sus negocios clandestinos, en su desinterés por la política, en su carencia de ideales y de un definido concepto de patria, datos todos ellos que diseñan a un hombre sin señas identificadoras. Estas historias de crímenes y locuras conforman, para el autor, parte de la identidad de América Latina; es la historia no reconocida, no oficial, que no obstante permanece imborrable para ir emergiendo en la memoria de lo "mal-dito". Esta tensión se exaspera en el último capítulo cuando Montenegro muere.

El protagonista arriba al Río de la Plata como un hombre sin identidad, "porque él había regresado de la nada y era un hombre sin rostro". Amparado por la dirigencia política funda su propio poder como 
"Príncipe de la muerte", gobierna sobre la "ciudad invisible, poblada de huesos y de muertos sin memoria (...) que acechaba detrás de la amable urbe que a todos complacía". En un encuentro imaginario, Lucas Aguirre le dice: "Tú no tienes nombre", "Tú no has vuelto". En el momento de su muerte "era un hombre sin patria el que allí moría, un príncipe sin historia el que había logrado construir su propio reino fuera del alcance de los hombres para albergar en él a todo lo negado y lo prohibido" (424). Esta pérdida de identidad de Montenegro es una metáfora de los procesos des-identitarios causados por las políticas violentas fraguadas en secreto, responsables también de una escisión constante de la unidad nacional, que el texto traduce en las imágenes contrastantes de la ciudad visible y la invisible, del discurso civilizador y la política de la barbarie, de la razón y la locura, del nombre y la anonimia.

Sin embargo, Montenegro recupera cuando muere "la catedral de sus palabras, la inmensa catedral que él había erigido durante toda su vida sin saberlo, noche a noche, pensamiento sobre pensamiento: cada amanecer estaba ahí, cada muerte, cada una de las víctimas de su cuchillo, de su machete, de sus conjuras, cada uno de los espectros (...) se guarecía en el templo de sus palabras. Tenían nombre y apellido y formaban una galería de sombras (417). En esta escena el silencio se convierte en palabra y discurso para ingresar a la historia. La intriga en clave policial no reside en las peripecias de las aventuras sino en la tensión entre el silencio y la palabra, articulada en dos tramas diferentes. Por un lado, tanto Montenegro como el oficial Peduzzi intentan resolver el enigma planteado por la frase del medallón ("la gota horada la piedra no por la fuerza sino cayendo a menudo") utilizando la tortura como método de interrogación, como modo de develar el secreto. En ambos casos fallan y el asesinato clausura la solución del enigma o, mejor, el asesinato reitera, sin saberlo, el significado de la frase (y lo reitera porque no lo sabe). En cambio, en el momento de su muerte Montenegro 
recupera aquello que en vida procuró ocultar, recobra su verdadera identidad y revela el tejido de su vida y de la historia.

La historia como repetición se expande al futuro en la novela, pues los crímenes de Montenegro se continúan en la apoteosis de las barbaries de la Guerra de la Triple Alianza, hecho no ocurrido todavía pero que se presenta en la memoria de Montenegro en el momento de su agonía: "Desde el futuro le llegaba la memoria de otros odios y otras muertes aún no acontecidas. Galopaban sobre la espuma de ese río los caballos de la destrucción, los potros de la guerra llegaban hasta él para narrar la historia, el delirio, el caudaloso infortunio que habría de prolongarse por años, mientras los dispersos despojos de su cuerpo iban convirtiéndose en polvo, en aire, en nada. Y supo el futuro" (409). La cita exaspera la repetición y se desplaza hacia el futuro apuntando oblicuamente a la última dictadura.

En el prólogo, Butazzoni aclara su proyecto fundado en la necesidad de reconstruir la memoria de la violencia como modo de restaurar una identidad más auténtica aunque no menos dolorosa: "vale la pena reflexionar acerca del sentido que ha cobrado con el transcurso de los años esa evasiva figura incrustada de manera irremediable en nuestro pasado: la historia a veces se nos muestra como una cruel cadena de repeticiones, y cuando uno intente bucear en las profundidades de hechos ocurridos hace mucho tiempo, puede con sorpresa hallarse ante semejanzas dolorosas $y$ enseñanzas mal aprendidas. La vida de Montenegro, su dilatada aventura y su prolongado negocio con la muerte, acaso no hayan sido más que el temprano signo de un cierto paradigma rioplatense. Desentrañar el sentido último de ese paradigma puede servir para conocernos mejor, para querernos más, para vanagloriarnos menos." (10). 
Desenterrar las memorias "mal-ditas" revela el gesto de revisión de la identidad uruguaya o rioplatense, la voluntad de reconocer los antecedentes de la última dictadura, de hallar el origen de la práctica de la violencia como una experiencia conocida, de elaborar un pasado en el cual ahora se vuelven a reconocer las huellas de eventos que, como larvas, habían incubado un sistema represivo. Cuestiona los imaginarios que hacían del Uruguay uno de los países más democráticos de América Latina para invitar a "conocernos mejor" como dice Butazzoni. Las memorias del pasado se constituyen en un lugar propicio para el aprendizaje, para corregir "las enseñanzas mal aprendidas" (Butazzoni). 


\section{LOS ARCHIVOS DE LA VIDA PRIVADA}

\section{El archivo de Soto de Mercedes Rein}

La vida pública y la privada se sobreimprimen en esta novela haciendo de la familia una imagen metonímica del cuerpo social. Su fuente primordial, el epistolario de Soto, constituye el eje que la narradora alternativamente glosa, cita y recrea. La índole biográfica del texto no se reduce a la figura de Juan José Soto o su hijo Carlos, sino que se extiende a las vicisitudes de todo el grupo familiar.

La familia es un espejo refractante de las fracturas y conflictos de la historia. La inestabilidad política de la segunda mitad del siglo XIX se muestra en el constante itinerar de los miembros de la familia por un circuito que marca el centro de los conflictos del momento: la coparticipación de Uruguay, Paraguay, Argentina y Brasil en una historia que los liga a través de guerras, batallas, pactos políticos, apoyo militar y transacciones comerciales que se extienden hasta Londres. Paralelismo entre la necesidad de construir y preservar un hogar, y el intento de consolidar un Estado-Nación tironeado por las disidencias, los vaivenes de la política y los procesos modernizadores. La vida familiar transcurre a los saltos: "Una vez más tenían que empezar a reconstruir el hogar" $(56){ }^{133}$

Las cartas resultan el modo de comunicación primordial que al mismo tiempo ponen en evidencia el desmembramiento de la familia y la voluntad de integrarla. Las cartas de Soto, privadas, diseñan, sin embargo, la red de comunicación político-comercial de la segunda mitad del siglo XIX y redistribuyen los espacios territoriales de cada nación en

133 Todas las citas corresponden a: Mercedes Rein, El archivo de Soto, Montevideo, Trilce, 1993. 
base a negocios e inversiones, pactos políticos entre blancos, colorados, federales y unitarios, las ayudas militares, las guerras en común y los poderes locales. Los estados aún no han logrado consolidar un poder centralizador que les asegure la suficiente autonomía y estabilidad; debido a ello Juan José Soto se exilia alternativamente en Brasil, Argentina y Paraguay. Perseguido en Buenos Aires por oponerse a la guerra de la Triple Alianza, puede asilarse en Entre Ríos, bajo el gobierno de Urquiza porque "era como un feudo aparte dentro de la República Argentina" (42).

Escribir estas cartas resulta para J.J. Soto una manera de restaurar la fragmentación de la familia instalando un momento de reunión y contacto entre los miembros dispersos. De modo más personal la escritura epistolar se convierte en un sucedáneo de su actividad periodística, siempre interrumpida por el poder político y de escaso rédito ("Como periodista podría arreglarse él solo. Pero ¿cómo alimentar a ese montón de hijos? Las letras son un lujo para los ricos o los solitarios empedernidos, piensa Soto", 64). A pesar de ello, Soto no se resigna, ratifica el valor de la escritura en su culto a las cartas que termina sustituyendo sus erráticos empleos: "Tú sabes que tengo la costumbre de escribir y esa es mi única ocupación" (64).

La carta inicial trae a escena el conflicto principal de la novela: el asesinato de su hijo Carlos a manos de los comandantes Santos, Tajes y Varela, servidores del "dictador Latorre". Inmediatamente su padre advierte que "La causa de ese crimen permanece aún envuelta en el más impenetrable misterio" (7). Un crimen y su resolución guiarán el desarrollo narrativo con un comienzo que parece augurarnos una trama policial. Pero el texto finaliza sin resolver el crimen, aunque cargado de diversas interpretaciones que tiñen de sospecha la versión oficial. El relato policial canónico se desvía y sirve, no para restaurar un orden sino para poner en escena el debate sobre las supuestas "verdades" de los 
documentos y sobre los modos legítimos de impartir justicia. Aquí la reescritura de la historia implica un doble propósito: desvirtuar la historia oficial sobre el asesinato de Carlos pero sin llegar a otra verdad, salvo la de poner en evidencia las contradicciones e incongruencias que presenta el caso. La imposibilidad de llegar a una certeza, las opiniones encontradas, la falta de claridad en los datos descubren la manipulación que el gobierno de Latorre hizo de los documentos a fin de oscurecer o borrar su responsabilidad.

Entre el comienzo y el fin del relato, sin embargo, la narración se reordena a través de paralelismos, acentuando las semejanzas entre reiterados episodios, destacando ciertas imágenes que condensan los significados de una violencia constante, que desde el espacio familiar se proyecta a la guerra de la Triple Alianza. En ello radica la densidad significativa que la ficcionalidad opera sobre la historia, más allá de la resolución del enigma: "Nunca lo sabremos ni sabremos lo que Héctor ocultaba y temía tanto ¿Otro complot? Puede ser, aunque suene novelesco, aunque los historiadores rechacen este ejercicio de simetría delirante" (142).

Las cartas, entonces, cumplen otra función relevante. Permiten elaborar versiones diferentes de los hechos históricos y contradecir la interpretación oficial. No todas las cartas que se transcriben en esta novela están escritas por los Soto. Dos de ellas, una firmada por Máximo Santos y la otra por Valentín Martínez, dan pie a una hipótesis distinta del asesinato de Eduardo Beltrán. Si la versión oficial dictaminó que se trataba de un "crimen pasional", estas cartas descubren "el trasfondo político de este supuesto crimen pasional (...) es posible que su muerte haya sido un crimen político digitado por Santos y Latorre" (131).

La narradora revisa y comenta todas las alternativas del juicio por el asesinato de Beltrán que culminó en la absolución completa del 
acusado Martínez. Resulta uno de los pocos ejemplos en que el asesino adquiere nombre y apellido, el caso se hace público y es juzgado por los tribunales del estado. No obstante el poder judicial se somete al poder político. La reposición del juicio por parte de la narradora, la cita de una de las cartas que desapareció en el momento del juicio ("El Fiscal consideró que esa carta era una prueba decisiva para la acusación. Pero no pudo presentarla porque los caminos de la justicia suelen ser un laberinto inextricable" ) y la afirmación del carácter político del atentado, intentan restaurar una parcela de la verdad histórica, aun cuando nada queda resuelto ni cristaliza en una respuesta.

\section{Los entresijos de la historia}

La historiografía evita lo que la literatura autoriza: la duda, las ambigüedades, las múltiples interpretaciones y los casos sin resolver.

La narradora elige contar la historia desde un ángulo preciso, delimitado, el que le provee el archivo Soto conservado en el Museo Histórico Nacional y que contiene ocho libros de unos quinientos o más folios con cartas escritas desde 1860, en su mayoría por Juan José Soto y algunas por su hijo Carlos. Este encuadre le permite desligarse de las exigencias planteadas al historiador de "reconstruir (...) un pedazo de la historia nacional" y optar por "hurgar en sus entresijos" (9).Colocándose en el lugar del autor a través de un prólogo inserto ya iniciada la novela, dice expresamente la narradora: "Lo que importa es contar una historia. No la historia sino una, una más de ese pasado que duerme en los archivos, en las memorias..." (9). ${ }^{134}$

La dimensión familiar, el espacio de la intimidad, las memorias de lo privado se reiteran en estas novelas. Evidentemente se abandona la

134 No obstante el narrador se vale y cita otras fuentes como notas periodísticas, comentarios de historiadores, archivos históricos, etc. 
perspectiva de la historiografía hegemónica, pues los documentos en que se ha fundado parecen inútiles para lo que se busca. ¿Estas operaciones se reducen a la oposición -importante sin duda- entre historia oficial y no oficial, pero un tanto esquemática en el reparto de responsabilidades? En El archivo de Soto, Carlos -la víctima del poder de Latorre- no deja de ser responsable (o sospechoso) de participar en un complot contra el coronel. En ¡Bernabé, Bernabé! Josefina señala la responsabilidad de diversos sectores en el exterminio de los charrúas en tanto consideraban "imprescindible acabar con los charrúas", entre los cuales se encuentran "estancieros, (...) maestros, párrocos, jefes políticos y hasta receptores de Aduana" (55).

Vale la pena reiterar el comentario de Alicia Migdal : "Pero ¿cómo se formaron las larvas del terror en el Uruguay de fiesta democrática? ¿De dónde salieron los torturadores que fueron con nosotros a la escuela laica, gratuita y obligatoria, y vivieron en nuestro barrio, y en determinado momento imprevisible pasaron al acto?". ${ }^{135}$ Estas palabras sintetizan una de las percepciones predominantes sobre la dictadura como una ajenidad, una otredad absoluta, el punto más extraño a lo familiar en el sentido freudiano. Sin embargo, esta cita demanda desentrañar el carácter ominoso de la dictadura. Del concepto freudiano me interesa retener el proceso del devenir de lo "siniestro" a partir de lo "familiar" (lo entrañable, el hogar y la patria), el juego de diferencia y complicidad entre palabras que comparten la misma raíz -heimlich (familiar); unheimlich (siniestro)- y que en un corte estructural de la lengua se contraponen pero que en otro se imbrican, poniendo en escena la ambigüedad de su significado. Freud mismo concluye: "De modo que

135 Alicia Migdal, "Imágenes simbólicas y realidades históricas", en Identidad uruguaya: ¿mito, crisis o afirmación?, comp. H. Achugar y G. Caetano, Montevideo, Trilce, 1992, p. 26. 
heimlich es una voz cuya acepción evoluciona hacia la ambivalencia, hasta que termina por coincidir con la de su antítesis, unheimlich". ${ }^{36}$

Diluir el carácter siniestro de la dictadura es uno de los intereses de las novelas históricas abordado a través del reconocimiento de otros períodos atravesados por prácticas violentas. Es en el mapa de la historia del siglo XIX donde la última dictadura se vuelve familiar, donde se esfuma el sentido de fractura completa de la historia para eslabonar una continuidad.

Pero también la focalización en la familia introduce otro aspecto de este juego cómplice entre lo siniestro y lo familiar. Hay cierto gesto de desligar toda responsabilidad en la idea de la extrañeza de la dictadura, cuyo resultado apunta a atribuir la responsabilidad absoluta al sector militar -sin duda la tiene en alto grado- y consecuentemente omitir sus relaciones con la población. El tratamiento de la figura de Carlos en $E l$ archivo de Soto introduce esta dimensión a partir de la intimidad de la familia. No sólo deja entrever su posible participación en el complot, sino además la narradora, en varias oportunidades, señala la actitud protectora del padre frente a las sospechas que recaen en Carlos: "Si no lo hubo (desfalco), entonces todo se redujo a una calumnia absurda, como afirma Soto aparentemente convencido de que su hijo sería capaz de hacer algo incorrecto" (41); "Tal la versión de los hechos que don Juan José elaboró y dio por definitiva haciendo recaer toda la culpa sobre la "despreciable manceba" (49); "El padre estaba completamente seguro de que su hijo no había hecho ninguna cosa indigna" (51) y "Don Juan José, en cambio, siempre negó que su hijo hubiese participado en un complot criminal y llegó a conjeturar que la causa de su desaparición pudo ser el famoso negocio de los muelles" (136) Por otro lado, tanto Juan José Soto como su hijo Héctor apoyaron la llegada al poder de Latorre

136 Sigmund Freud, "Lo siniestro", en: Obras Completas, Vol. 13, Bs. As., Hyspamérica, p.2488. 
Este perfil de Carlos, que en nada justifica la maquinaria de terror a la que fue expuesto, sin embargo introduce una perspectiva diferente sobre lo familiar. De ningún modo quiero hacer una lectura mecánica que asimile a Carlos con una víctima de las dictaduras de la década de 1970 , lo cual conllevaría otro peligro, justificar la dictadura diluyendo sus crímenes en toda la sociedad. Más bien se trata de matizar la percepción de la sociedad como una masa unívoca, monolítica, incapaz de respuestas o responsabilidades, "pura víctima". Desde luego que este tema fue debatido en la posdictadura. Al respecto dice Hugo Vezzetti: "Antes que de esta ficción de un poder absoluto e inaugural que se impone por el terror a una sociedad que es una pura víctima, ajena por entero al desorden del mundo, que le cae encima, de lo que se trata es de comenzar a preguntarse cómo fue posible que esta sociedad generara tal régimen", ${ }^{137}$ a lo cual añade "no se trata de concebir sujetos incontaminados y ajenos a esa violencia y esa facciosidad que la dictadura vino a expresar" (7).

En esta línea, El archivo de Soto no coloca a la familia como "pura víctima", ajena a la desgracia que le ocurre. Tanto Carlos como su hermano Héctor y la actitud complaciente de Juan José distan de representar a la familia ideal, enfrentada al régimen de Latorre y marginada por él. Lo "siniestro" se va diluyendo desde la interioridad misma de los familiar porque es allí donde también asoma una de sus puntas.

137 Hugo Vezzetti, "Derechos humanos y psicoanálisis", en Punto de vista, No. 28, Año, IX, noviembre 1986, p.6. 
2 Una cinta ancha de bayeta colorada. Desandanzas del Goyo Jeta de Hugo Berbejillo

Nuevamente sube a escena el gobierno de Latorre en esta novela de Hugo Berbejillo, en la cual el periodista Gaspar Salamanca aparece en la casa montevideana del general Gregorio Suárez, el Goyo Jeta en 1879, dispuesto a iniciar una entrevista que le permita escribir la biografía de aquél. La conversación está marcada por la situación política del viejo caudillo, ahora encerrado en su casa y custodiado por los sicarios del Presidente. Desde este presente se recuperan los hechos históricos -la gesta caudillista, las guerras civiles, los motines y traiciones- de las décadas inmediatamente anteriores. E1 relato se desarrolla en un instante, el de la muerte, mientras afuera se reitera, al comienzo y al final, la misma escena: el dependiente de la casa de confituras Langenus está cerrando el comercio y el propietario de la droguería Riepphof despide a una mujer. El caudillo ya ha bebido el veneno que, a punto de morir, lo incita a recordar su propia historia, a confesar sus crímenes ante el supuesto periodista.

El periodista Salamanca, por momentos casi voz de la conciencia del propio Goyo Jeta antes de su muerte, propone el ángulo de la biografía -"Usted me dirá sus motivaciones"- para encarar la historia, a través de una escena de interiores en la que elige colocarse en un cono de sombra, "lejos de la luz", marco casi confesional ("su voz será audible sólo para mí, con eso basta", 12). Ese ámbito permite descubrir y describir los aspectos más oscuros y sangrientos de la gesta de Goyo, la historia oculta y silenciada de crímenes y traiciones: "porque hay algo para decir para lo que no hay palabras, o tal vez no las hubo pero las puede haber y no pueden decirse (...) tal vez si usted hablara de eso, yo, con mi biografía, terminaría con el silencio" (22). 
Si El archivo de Soto articulaba una mirada desde el espacio de lo privado sitiado por los agentes del poder, en Una cinta ancha... el ángulo de la biografía propuesto por Salamanca, la mirada desde el interior de la sala y desde el fondo de la conciencia no remiten a lo familiar. La interioridad aparece asediada por los fantasmas que ella misma, al abrigo del silencio, ha engendrado. El relato de la violencia se vuelve una "confesión" más que del pecador a su sacerdote, del reo ante el juicio de la historia. Desde el comienzo, el relato procura una reparación simbólica de las víctimas del Goyo Jeta.

Dos sectores se imbrican en Una cinta ancha... a modo de contrapunto indicativo de los cambios y transformaciones desde las guerras civiles al gobierno de Latorre. Parodi y el Goyo Jeta representan dentro de la sociedad uruguaya al hombre de negocios de Montevideo y al caudillo de la campaña con sus diversos modos de vida, ideales, personalidades e intereses.

El texto se abre con el motín de Montevideo (1875) luego del cual el coronel Latorre se adueña del poder inaugurando una nueva época. La casta militar, personera de los sectores prominentes del comercio y las finanzas montevideanos y de los latifundistas de la campaña, sienta las bases de un poder centralizado, el del Estado moderno, único capaz de asegurar, a su juicio, la paz que estos sectores solicitaban para que la modernización del país estuviera a la altura de los reclamos extranjeros.

Este es el presente que, desde su ventana, observa el Goyo Jeta y que Salamanca se ocupa de señalarle: "Las barrigas prominentes de los comerciantes de ultramar, los nuevos dobles apellidos compuestos (...) las nuevas recepciones sociales en las casas quintas del Prado". Tales cambios repercuten en la campaña en vías de modernizarse: "los animales de raza (...) las estancias, general, ya no tienen peonada que levantar a punta de lanza al grito de la divisa (...) Ya se pudrieron los huesos de los 
últimos gauchos de vida alzada". Fueron obra de Latorre las medidas que implementaron estos cambios: "Y ya el país tiene una autoridad central, general" (14), "El alambrado de los campos y la Ley de Abigeato y el Código Rural". Este presente de Latorre clausura el poder de los caudillos, sus valores y sus luchas, convirtiendo el pasado de Gregorio Suárez en un "museo".

En torno a la figura del Goyo Jeta se desanuda la historia de las guerras civiles, con sus principales actores, Oribe y Ribera, Venancio Flores, César Díaz, Anacleto Medina, Leandro Gómez, Timoteo Aparicio, junto a la presencia de argentinos, brasileños, paraguayos e ingleses. Los sucesos se encadenan unos a otros, Arroyo Grande, Quinteros, La Cruzada Libertadora, Paysandú, la guerra de la Triple Alianza contra Paraguay, en fin, los motines, levantamientos, pactos, intentos fusionistas y reacciones, asesinatos, que signaron la historia de luchas sangrientas.

Estas dos fuerzas históricas, que articularon los principales sucesos del Uruguay de entonces, se van tejiendo paralelamente a lo largo de la novela desde su mismo inicio. Con un "Estado débil", en un país dividido entre Montevideo y la campaña -"no un país sino una endeble suma de islas de poder"-, Parodi y Gregorio Suárez comienzan, de modo paradigmático, a diseñar su propio poder. Parodi, "flojo" para la guerra, comienza su carrera en Montevideo con "su escritorio y su tintero"; carente de escrúpulos, asciende vertiginosamente en la escala social a través de la especulación con certificados de sueldos, comprando títulos de Deuda del Estado, acaparando tierras fiscales e iniciándose en variados negocios. Modos del ascenso de los sectores financieros y comerciantes que fueron adquiriendo poder a través del dinero, de la Bolsa, de los recientes Bancos, de la especulación financiera y del usufructo de los dividendos que las guerras permitían sin el costo de ensuciarse las manos en el frente de batalla. 
Gregorio Suárez da las pautas de su ingreso al poder según las normas de la campaña, coloca una pulpería en su pueblo natal, lugar de reunión privilegiado como centro de la formación del caudillo y su gente: "Usted ha de saber: pulpería en poblado: acreedor de muchos y sabedor de vidas: hombre respetable, prestamista a veces. Y en aquella época caudillo local quería decir Jefe Político, con apoyo de la gente principal" (46). Desde allí emprende su periplo caudillista.

Unos hacen la guerra sangrienta, los otros ganan fortunas usufructuando de la situación, y ambos terminan imponiendo sus intereses. Algo, sin embargo los diferencia. Mientras los militares hacen la guerra, el sector financiero parece parodiarla. A modo de ejemplo: se prepara la guerra de la Tripe Alianza contra Paraguay y Parodi -¿parodia?- recién nombrado proveedor del Ejército, confecciona trajes y carpas de campaña: "Guerra, dicen, Parodi, ahora. Y entonces Parodi hace entrar un pequeño ejército de costureras señoritas" (124). En varias ocasiones Parodi reitera, en clave paródica, sucesos acaecidos a Gregorio Suárez.

Este contrapunto, que termina por limar las diferencias entre Montevideo y la campaña, remite, como ya vimos en otros textos, a la consabida distinción sarmientina entre civilización y barbarie, cuya fundamentación se encuentra en una cita atribuida a Sarmiento: "es preciso emplear el terror para triunfar en la guerra" (115). La barbarie de la civilización se presenta en Parodi con su bienvenida a la guerra como negocio: "-Dios no lo oiga, hombre: la guerra lleva los negocios al carajo; -Se equivoca, mi amigo: no hay negocio más brillante que la guerra" (113).

Berbejillo privilegia la reflexión sobre el sector financiero, no tan presente en el resto de las novelas históricas. La historia, más que de pactos entre caudillos y militares, resulta obra, agencia de intereses 
comerciales y en especial financieros. Aquellos sólo resultan personeros de los capitales de la alta burguesía montevideana y, en última instancia, de los intereses ingleses, triunfantes con el gobierno de Latorre. Ésta es -para la novela- la verdadera historia que queda oculta en los textos: los intereses del dinero obran en el anonimato histórico, al margen de los colores de las divisas o guiando la política con hilos invisibles; mientras los eventos -batallas, fechas memorables, nombres- con los que se narra la historia emergen en la superficie de los textos históricos, éstos dejan en la sombra a sus reales agentes.

El periodista Salamanca explica esta lógica: "Los verdaderos generales se sirvieron de los soldados como usted para hacer la verdadera historia, que quedó oculta en las cifras de los Libros Mayores y de los Diarios y sobre todo de las cuentas de Pérdidas y Ganancias, y tuvieron la deferencia de permitirles hacer otra historia, la de ustedes, la que servía para que se sintieran útiles -que lo eran y lo son, todavía-, la historia pequeña de las discordias y las batallas, de los pactos y las fechas, de las fotos de uniforme y las plaquetas recordatorias: la historia de museos" (267-8).

El peso del sector financiero junto al militar no fue ajeno al orden de poderes instituido por las últimas dictaduras del cono sur. Vale la pena citar a León Rozitchner: "se juzgó a un puñado de militares culpables del terror de Estado, pero no se incluyó en el juicio a los otros poderes responsables: el económico, el político, el religioso, el de los medios de comunicación". ${ }^{138}$

La historia como repetición reaparece en la temporalidad circular de esta novela. Una cinta ancha... abre y cierra el relato con el motín de Montevideo del 10 de enero de 1875. Pone en escena la imposibilidad de llevar a cabo un acto eleccionario y su consecuencia: la toma del poder

138 Cita tomada de F. Reati, "Introducción, en: Memoria colectiva y politicas del olvido, op. cit. 
por parte de Latorre, inaugurando la primera dictadura uruguaya. Esta circularidad del relato se complementa con una temporalidad construida en base a reiteraciones. La lógica de la historia de las guerras civiles se desnuda a través de eventos que, con diferente nombre, reiteran las mismas prácticas del degüello, la venganza, la traición. Los subtítulos nos remiten a ellas: "el puñal", "la bala", "el odio", "la bayoneta", etc. El texto coloca en paralelo a Quinteros y Paysandú como ejemplos de la práctica de blancos y colorados. Constituyen dos pivotes históricos que repiten las mismas acciones: documentos que incitan a la rendición con la promesa del respeto a la vida de los prisioneros de guerra, seguidos por la traición de los mismos y el fusilamiento final. La idea de un tiempo que se copia a sí mismo trama un relato que, en cada coyuntura, en diversos enfrentamientos armados, culmina con la descripción de los muertos sobre la tierra:

"y el velo de agua fina por varios días después ayudó a los perseguidores a dejar un tendal de degollados por varias leguas a la redonda, olvidados, abandonados, tras el viento final que limpió el cielo y los soles sucesivos, a disposición de los perros salvajes, prolijamente descarnados por las aves carroñeras, senda pútrida de las hormigas, anónimos para la historia, insepultos, disueltos en sales orgánicas, vueltos un charco para adentro, colados por la tela del uniforme hacia la tierra, a otras sales, a mejorar la pastura" (26).

La "repetición" como lógica de la historia de la violencia resulta una constante en estas novelas. ¡Bernabé, Bernabé! articula una "serie" (en el sentido foucaultiano, una serie como capa superpuesta a la serie de la temporalidad lineal del progreso) que enhebra momentos que van desde el origen hasta la última dictadura; en El príncipe de la muerte, la "repetición" se abre como un efecto traumático de lo mal-dito de la 
historia (de la violencia no dicha). En El archivo de Soto, las repeticiones -en un corte sincrónico- establecen una "simetría delirante" (Carlos, Beltrán, Héctor) que apunta al presente como un espejo "para conocernos mejor". Las cuatro novelas coinciden en postular el presente de la última dictadura como el último eslabón de la repetición y en señalar su dimensión pedagógica (la historia como magistra vitae).

Una cinta ancha... no se reduce a la confesión del Goyo Jeta a Salamanca; el relato integra diversas voces de muertos que reclaman autoridad, piden ingresar a la historia. Volver a relatar el pasado, convertirlo en historia implica, para Berbejillo, articular el punto de vista de los muertos, saldar una deuda impaga con "los anónimos para la historia", ya que "los muertos tienen derechos, general: pueden volver cuando quieran, porque no pierden la memoria" (15).

El espectro de Lucas Bergara, degollado por orden de Latorre y arrojado al agua, se introduce en la sala. Previo a estas escenas, la novela se abre con un "Preludio en el agua". El Comandante Felipe Frenedoso cuenta su propia muerte a manos de sicarios de Latorre, quienes luego lo arrojaron a las aguas de la bahía. La escena culmina con la devolución del cadáver a tierra, preludio de los múltiples cuerpos que se levantarán de la tierra para ocupar un lugar en la historia: la cabeza que no logran enterrar de Críspulo Sosa, la aparición fantasmal de César Díaz durante el sueño del Goyo pidiendo venganza, el recuerdo de la madre muerta del Goyo y, finalmente, las manos de los muertos que piden explicaciones, reclaman una justificación por sus muertes al General Gregorio Suárez, las manos de sus propios hombres y enemigos: "Los tuyos también murieron, general: te los están matando (...) mataste a los míos en Soriano (...) y también en Sauce (...) Murieron de los míos, pero también de los tuyos, y la tierra espera, general; siempre espera" (257). 
Cada batalla finaliza con la imagen de los cadáveres insepultos, la imposibilidad de enterrarlos, los cadáveres que el mar devuelve, los fantasmas que acosan a Gregorio Suárez. Los muertos permanecen insepultos porque aún deben ser redimidos. Como en Benjamin, la utopía, la esperanza se sitúa en el pasado y la historia debe redimirlos a través de las palabras, de un relato que convoque sus recuerdos, que se haga cargo de sus reclamos.

Aquí se hace presente una de las secuelas del terrorismo de Estado, la imposibilidad del duelo. Este obstáculo adquiere una doble dimensión: como efecto traumático en el cuerpo social que ocasiona un vacío, una "pérdida" que sólo es posible tramitar a partir del duelo. La recuperación del cadáver implica la restauración de la identidad de víctimas y victimarios, la reposición de la cadena histórica. Pero también la necesidad -y el impedimento- del duelo tiene una dimensión política. La negación del rito provoca una respuesta social organizada, que a través de nuevos rituales (las rondas de las Madres de Plaza de Mayo, el uso de pancartas con fotos de los "desaparecidos") intentan desplazar el vacío y reconvertirlo en praxis política. Una cinta ancha... presenta las derivaciones traumáticas de la ausencia del duelo en la historia, al tiempo que coloca a la escritura como vehículo para una reparación simbólica.

\section{El Archivo}

En casi todas las novelas históricas aquí analizadas, el archivo constituye un tema recurrente, no sólo como fuente a la que acuden los autores y sobre el cual reflexionan en sus prólogos. Es, además, un motivo que se ficcionaliza en el interior de la trama. 
En Mal de archivo Jacques Derrida describe la noción de archivo a partir de su etimología. ${ }^{39}$ "Arkhé" alude al mismo tiempo a la idea de comienzo, origen, fundamento físico, histórico u ontológico; pero también al principio de la ley y la autoridad. "Arkhé" se relaciona con "arkheîon": la residencia de los arcontes, de los magistrados superiores, de los que representaban la ley. Guardaban y conservaban en sus casas los documentos y tenían la potestad de interpretarlos y velar por el cumplimiento de la ley.

Las novelas históricas recuperan este sentido del archivo como lugar a la vez del origen de la nación y de su ley, como espacio de la autoridad que ha diagramado un orden, un origen y un relato. Derrida señala la función de "consignación" del archivo que otorga una regularidad y un sentido a los documentos del archivo, los coloca en un relato teleológico, los reúne en una unidad compacta, sin fisuras: "La consignación tiende a coordinar un solo corpus en un sistema o una sincronía en la que todos los elementos articulan la unidad de una configuración ideal" (11). Pero es este principio de consignación lo que las novelas históricas van a desarticular a partir de la reapertura de los archivos.

El archivo como soporte del origen único se disocia en estas novelas para señalar allí mismo otro origen, el de la violencia ejercida por el estado. El corpus de novelas históricas recorta en la historia del siglo XIX, dos orígenes: la independencia en los inicios del siglo, y la modernización y consolidación del estado llevadas a cabo bajo la dictadura de Latorre. ${ }^{40}$ Ambos orígenes, como ya vimos, aseguran dos

139 Derrida, Jacques, Mal de archivo, Madrid, Trotta, 1997.

140 Es visible, asimismo, el intento por diluir el carácter unívoco y prefijado del "origen" nacional y sustituirlo por una apertura hacia la pluralidad. La dimensión "ficcional" del discurso histórico, señalada reiteradamente por los críticos, autoriza un margen de libertad en los posibles recortes de la historia. Cada nuevo relato selecciona su propio "origen", sujeto a los intereses y postulados inscriptos en el 
ordenamientos, por un lado, el relato de la independencia como un logro oriental ("tesis de la independencia clásica") y, por el otro, la trama del progreso y la democracia (lo que luego será consolidado en el imaginario batllista). Las novelas quiebran estas narraciones fundacionales del archivo y retrazan el itinerario de la historia deteniéndose en los momentos de emergencia y predominio de la violencia ejercida por el estado. Cuestionan la misma idea de "origen" establecida por el archivo. El origen de la nación independiente pierde su aura con el exterminio de los charrúas; el origen del estado -su pacificación, consolidación y modernización- coincide con la dictadura de Latorre.

El origen de la violencia de estado sustituye, entonces, al de la nación-estado de un modo casi obsesivo en estas ficciones. Pero no se trata de una mera inversión, sino de la inscripción de la violencia en el espacio del origen fundacional. El relato retiene las marcas del entramado épico-heroico-progresista para escribir en su interior el contrarrelato de la violencia. $^{141}$ Por ello, se privilegia una serie de imágenes duales y antitéticas, una suerte de Jano, que al mismo tiempo retoma y critica el

armado de ese mismo relato. Entonces el origen se convierte en un punto de elección -anclado, desde luego, en hechos históricos relevantes-, en un lugar ambiguo que puede variar según las necesidades del presente. Conviene entonces hablar en plural no sólo porque son múltiples los posibles lugares del origen nacional, sino porque, además, varía su índole. Hugo Achugar señala claramente la pluralidad de posibilidades en la elección de un origen: "¿Cuándo comienza Uruguay? ¿Comienza con los charrúas, con las vacas ingresando a nuestras llanuras de la mano de Hernandarias, con Artigas, con la batalla de Carpintería, con Latorre y al alambrado de los campos, con los inmigrantes bajando de los barcos, con Batlle y Ordóñez, con las primeras gremiales obreras, con la crisis del treinta y la dictadura de Terra, con Maracaná, con la crisis de los sesenta y los tupamaros, con la migración de los jóvenes, con la dictadura de los setenta, con la democracia, con la integración regional, mercosuriana o de la otra?. Decir cuando comienza Uruguay es de algún modo decidir en qué país se vive y a qué futuro se apuesta." Hugo Achugar: $L a$ balsa de la Medusa. Ensayos sobre identidad, cultura y fin de siglo en Uruguay, Montevideo, Trilce, 1992.

141 Es cierto que la violencia es también parte constitutiva de la épica, pero queda subsumida y justificada en la "gloria" alcanzada por el guerrero, en el "sacrificio" como salvación de la patria, tal como comentamos a partir de las novelas de Eduardo Acevedo Díaz. 
valor de lo heroico característico de las narrativas hegemónicas del origen nacional, señalando las contradicciones entre los discursos oficiales y sus prácticas bárbaras. ${ }^{142}$

El origen, entonces, pierde su dimensión ejemplar, su poder como arkhé, principio y ley, para devenir en "inicio". En un giro similar al que da Foucault en su lectura de Nietzsche, quizás resulte útil sustituir la idea de "origen" por la de inicio o emergencia, para señalar el gesto desmitificador característico de estas novelas históricas. ${ }^{143}$

Dice Derrida: "En un archivo no debe haber una disociación absoluta, una heterogeneidad o un secreto que viniera a separar (secernere), compartimentar, de modo absoluto. El principio arcóntico del archivo es también un principio de consignación, es decir de reunión" (11). Las reaperturas de archivos provocan la fractura de su ordenamiento e introducen diversas heterogeneidades: las alteridades indígena y negra en las novelas de Tomás de Mattos, los "secretos" de violencia y locura que desoculta $E l$ príncipe de la muerte, los "casos sin resolver" en $E l$ archivo de Soto, y los "fantasmas" de Una cinta ancha... Estas novelas discuten el lugar y la ley ("la civilización", la "modernización", el "progreso") según las cuales se funda el archivo, interrogan su legalidad al tiempo que bucean en los mismos archivos lo que no ha sido consignado, las zonas amenazantes, las historias privadas, los relatos reprimidos, las censuras, las violencias, el "mal de archivo".

142 En esta imagen, así como en las relecturas de la historia nacional que estas novelas llevan a cabo, es posible percibir un impulso similar al que guía a $\mathrm{H}$. Bhabha en la exploración de un "espacio nacional ambivalente", aquellas zonas "ambiguas", los "bordes", los "repliegues" que han escapado a las "narrativa continua del progreso nacional", Cfr.: "Introduction: narrating the nation", op. cit., pp. 1-7.

143 Foucault, Michel, "Nietzsche, la genealogía, la historia", en: Microfísica del poder, Madrid, La Piqueta, 1979, p. 7-29. 
Ya dijimos, las novelas ficcionalizan el archivo al tiempo que lo utilizan como fuente, y ambas cuestiones no siempre coinciden. En ¡Bernabé, Bernabé!, Tomás de Mattos utilizó como fuente La guerra de los charrúas en la Banda Oriental de Eduardo Acosta y Lara, de la cual extrae tanto documentos históricos de la época, partes de guerra, informes, cartas que, en la ficción, se convierten en el Archivo Narbondo; como el relato del exterminio de los charrúas consignado por Manuel de Lavalleja y por Antonio Díaz (hijo) que pasa a configurar el archivo oral de Gabiano. Cercena, entonces, la unidad del archivo en una versión escrita que consigna la opinión oficial de los vencedores (es, además, el archivo del marido de Josefina, con quien su padre coincide, de allí su dimensión "patriárquica") y otro archivo oral que recupera la voz de los vencidos charrúas.

Según Butazzoni El príncipe de la muerte nació de las dificultades que le impedían el acceso al archivo; la novela entonces narra el "secreto" del archivo. En su prólogo, el autor expone las peripecias y obstáculos para ingresar a los archivos oficiales o privados: "Cuando en 1985 comencé a investigar en los archivos oficiales con la intención de escribir una biografía de Montenegro, descubrí (...) que era un muestrario de contradicciones flagrantes; de hechos falsificados con el propósito de forzar las interpretaciones y de datos cuidadosamente ocultos a la consideración pública" (7); "Un prolijo relevamiento de la hemeroteca de la Biblioteca Nacional, en Montevideo, me mostró con claridad que era poco o nada lo que se conocía de Montenegro o que, en todo caso, ese conocimiento había sido ocultado durante más de un siglo" (8); "Cuando intenté investigar en Buenos Aires y comencé preguntando acerca del paradero de ciertos documentos de épocas todavía no exhumados de colecciones privadas, hallé no sólo reparos sino también veladas amenazas" (8). 
Si en principio Butazzoni se propuso escribir la biografía de Montenegro, las trabas de los archivos lo condujeron a la ficción. La clausura del archivo determinó dos operaciones del texto. Por un lado el uso de la ficción: Butazzoni comienza con una cita de Saramago -"Todo es ficción"-, que incluso, sospechamos, tiñe también su prólogo ficcionalizando su peregrinaje por los archivos para reponer la historia excluida de ellos. Por otro, la novela -como ya analizamos- pone en escena el motivo del secreto que engendran los "Archivos prohibidos". El poder político como controlador y censor del archivo impide la lectura del mismo. Estas novelas, entonces, reabren los archivos como un gesto y una política democrática. El acceso libre a los archivos, a su configuración, a su interpretación y a su relectura instala una demanda de participación.

La figura de Montenegro introduce el "escándalo" (7) en el archivo oficial, y es ese signo escandaloso, esa ruptura la que permitiría acabar con una historia que se reitera a sí misma (con la "cadena de repeticiones"): lo mal-dito inaugura un nuevo principio que, como en ¡Bernabé, Bernabé!, desarma el origen con la violencia.

El Archivo de Soto elige un archivo de la vida privada pero sus personajes participan de la vida política y se ven envueltos en un crimen fraguado por el gobierno de Latorre. La condición de este archivo privado, su locus de enunciación no es la ley que interpreta para unificar (la "consignación") sino la ambigüedad, las dudas, las múltiples interpretaciones, los "casos sin resolver". Sustituye "la historia" por "una historia", abandona la superficie por sus "entresijos", sus "pedazos".

En Una cinta ancha... emergen del interior del archivo los fantasmas que éste expulsó o reprimió de su memoria, los espectros que se resisten al olvido y -como el padre de Hamlet- reclaman justicia o al menos una reparación simbólica con su reingreso al archivo. Berbejillo 
señala además los procesos de anonimia por los que el sector financiero hizo invisible su rapacidad en el archivo.

Una de las notas perceptibles en varias novelas radica en el cruce de opiniones, puntos de vista, posiciones políticas enfrentadas, diversas versiones sobre un mismo hecho. La apertura del archivo, al tiempo que expone su diversidad, no quiere volver a cerrarlo con un perfil unívoco. Al respecto dice Derrida: "La democratización efectiva se mide siempre por este criterio esencial: la participación y el acceso al archivo, su constitución y su interpretación. Al contrario, las infracciones a la democracia se miden por lo que una obra reciente y notable por tantos motivos llama Archivos prohibidos" (12). La apertura del archivo en estas novelas pone constantemente en escena las opiniones encontradas, los argumentos de las grandes líneas que definieron las políticas del siglo XIX, las razones de la "civilización" y la "barbarie", de la modernización y sus prácticas, las continuidades y rupturas de la historia (más cercano a los términos en que Foucault define el archivo en La arqueología del saber).144

Ya vimos la importancia del "diálogo controversial" en ;Bernabé, Bernabé!. El archivo de Soto se cierra con más de un caso sin resolver y no se ahorra la posible culpabilidad de Carlos. En Una cinta ancha... Salamanca va multiplicando los ángulos de la historia, introduce gacetillas, cartas, partes de campaña, epístolas femeninas, citas de historiadores, diálogos, opiniones diversas cuando un viento sur arrasa los papeles que el General Suárez guardaba con celo y los confunde, los

144 Aunque el "archivo" cobra otras dimensiones en este texto de Foucault en tanto configura el sistema de funcionamiento de los enunciados, es perceptible una concepción mucho más abierta del archivo en cuanto éste no obedece sólo a una "linealidad sin ruptura" (220), sino que "nos desune de nuestras continuidades; disipa esa identidad temporal en que nos gusta contemplarnos a nosotros mismos para conjurar las rupturas de la historia; rompe el hilo de las teleologías trascendentales" (223), de: "El apriori histórico y el archivo", en: La arqueología del saber, México, Siglo XXI, 1985. 
mezcla en una superficie que hace visible los diversos puntos de vista sobre el pasado, las razones de blancos, colorados, fusionistas, intransigentes. "No va a haber uniformidad cuando escuche otras voces, las ajenas: no puede haberla -nunca la hubo- pero menos todavía desde la aparición de los cintillos partidarios, desde Rivera y Oribe" (15).

Demás está decir que la crítica al sistema de violencia se coloca un paso más allá de las tomas de partido. En estas novelas no se advierte ninguna tendencia que procure enaltecer la historia de blancos o colorados ni defender alguna ideología partidista en particular. Montenegro desacredita sin distinguir unitarios de federales, colorados de blancos: "Montenegro estaba en el reverso de esa trama, al igual que muchos otros que se las ingeniaban para vender sus servicios al que mejor pagara, pues lo cierto era que en ambos bandos mandaba la codicia, la voluntad de que fueran siempre otros los que mataran y murieran" y critica tanto a Mitre y Sarmiento como a Urquiza (340-41). Una cinta ancha... apunta a los métodos mismos de la violencia, que engloban por igual a los diferentes partidos: "Colorados, blancos: tanto da: la tierra jamás preguntó la procedencia de la sangre" (267).

\section{Los íconos de la nacionalidad}

En el capítulo anterior expusimos dos operaciones frente a la memoria: las políticas del olvido y las apropiaciones de la memoria por parte de la dictadura y la posdictadura. Si bien analizamos en las novelas históricas el rescate de memorias olvidadas, dejamos pendiente los procesos de desmantelamiento de los monumentos nacionales.

En la narrativa de Eduardo Acevedo Díaz los emblemas de la nación, en especial la bandera, los nombres de las batallas, los muertos en holocausto al ideal patriótico, las costumbres de los gauchos, los bailes y 
cantares, la naturaleza oriental, los personajes representativos, la confraternidad entre las razas... todo parece contribuir a diseñar una tradición nacional capaz de fortalecer el origen heroico del pueblo oriental, con el propósito de consolidar la viabilidad del Uruguay en vías de modernizarse. Por el contrario, la deconstrucción de los íconos oficiales de la nación emerge como una constante en las novelas de la posdictadura, guiadas por el afán de volver visibles los mecanismos de edificación de monumentos por el poder.

El relato desde la perspectiva de Montenegro, desde el punto de vista del criminal, resulta un ángulo privilegiado para develar los secretos de la historia oficial en El príncipe de la muerte. Montenegro se queja: "Ay de la Historia escrita con mayúsculas como quieren estos cagatintas, pensaba el cuchillero (...) Ay de la Historia en el mármol esculpida, reflexionaba Montenegro (...) Ay de la Historia contada por los vencedores (...) ay de la Historia no contada por los historiadores." (344-347).

En términos similares, Salamanca le explicita al General Gregorio Suárez la índole de su biografía que se aleja de las versiones de la Historia con mayúsculas, "Nada de monumentos ni de óleos".

Los íconos que representan la nación, los lugares que guardan la memoria colectiva, los trofeos y monumentos, ocupan también un lugar importante en Una cinta ancha...

En primer lugar esta novela invierte la imagen de los militares como Padres de la Patria y custodios de su integridad, para convertirlos en sus violadores. La Patria se recubre con los rasgos femeninos de una doncella para ser objeto de diversas violaciones. Parodi, según cuenta su esposa, "desflora" a su patria apropiándose fraudulentamente de tierras fiscales -"qué habrá que Parodi no haga, no viole, no adultere ni desmerezca: la Patria niña, desflorada" (172). El brutal Doroteo Meireles, 
el Pardo, al servicio del Goyo Jeta, viola literalmente a la hija de Baz. Gregorio Suárez imagina su acceso a la Presidencia a través de la posesión sexual de una joven que se desvanece y "al salir me mostraba las nalgas grandes y generosas" (222). En síntesis "La pobre Patria víctima de militares y mercachifles que se aprovechan hasta la náusea y quién la defiende" (174).

La estatua de la Plaza Cagancha esconde su verdadero significado -una victoria colorada- bajo un símbolo nacional que borra las implicancias partidistas bajo la apariencia de una unidad inexistente:

"Se inauguró ayer (...) una estatua en plena Plaza Cagancha. La misma, a cargo del escultor José Livi, representó al principio la Victoria de la Cruzada Florista, con una espada romana en la mano, y el pie hollando la cabeza de un monstruo abatido. En virtud de limar asperezas políticas -es el caso recordar que hay ministros blancos en el gobierno colorado-, se la modificó para que representara la Libertad, con la Constitución en el brazo. Fue fundida a partir de dos cañones de bronce y costó siete mil doscientos pesos" (101)

En esta cita sobre la estatua de la Plaza Cagancha se descubre el proceso de purificación de los monumentos nacionales (el monumento como "precipitado químicamente puro" para Nora) a través de la disolución de los conflictos en una concordia que no es más que un simulacro. Por contraste los verdaderos trofeos de guerra, no públicos sino privados, secretos, están guardados en un mueble con llave del Goyo Geta: la cabeza seca de Basilio Mora, el bastón de Bernardo Berro y la barba del General Leandro Gómez. El bajorrelieve de este mismo mueble 
descubre la lógica dual, la ambigüedad que rodea la interpretación de un símbolo, de una alegoría:

"las figuras de tres demonios: la Guerra, el Hambre y el Odio, o bien de un monstruo con tres cabezas (...) avanzando sobre la ciudad (...) pero antes de que se precipiten sobre ella, aparece una figura (...) que los detiene con una mano levantada en un gesto de exigir un "atrás" enérgico y decidido (...) los maliciosos sugieren que el personaje representa al Parlamentario, al Diputado, y que en realidad no los rechaza a los demonios de la guerra sino que les sugiere un compás de espera hasta que las gentes de la ciudad olviden los últimos desmanes por ello cometidos" (103-104)

El entierro de Venancio Flores, de otro modo, también pone en cuestión la unidad nacional, separando simbólicamente el cuerpo de la cabeza:

"Y en algún momento resolvieron que así fuera, y así fue, y así quedó en silencio, y fue dispuesto que la mayor parte del General fuera en secreto y al oscuro y para siempre, en cajón común: el hombre Flores con sus heridas y traiciones (...); y casi un mes después, su cabeza, en cajón de lujo, presidencial, la cabeza de las estampas y las litografías, la que quedaría en la historia" (213)

Mientras Gregorio Suárez no logra enterrar a su madre y procura vengar su muerte causada por los blancos, Parodi monta un espectáculo 
para el entierro fraudulento de la suya: "Que iba a enterrar Parodi, si apenas conoció a su madre y dejó de verla de niño y de tan poca edad como para acordarse (...) Pero sé que en ese cajón no iba madre de nadie: iba Juana Guzmán, india de las bocas del Cufré, tenida por bruja de las de agriar la leche en la misma ubre de las vacas" (72).

Si la imposibilidad de enterrar los cadáveres, -el obstáculo al duelo- instaura una pérdida y una deuda en la historia, los rituales fúnebres del aparato estatal la saturan con sus simulacros.

\section{El imaginario de la(s) dictadura(s)}

Frente a las políticas del olvido, ante los usos abusivos de la memoria por parte de los gobiernos, contra el principio unívoco del archivo -en tanto políticas heredadas de la última dictadura-; éstas novelas históricas reabren los archivos del pasado para volver a narrarlo ahora desde la agenda de la posdictadura. La cual impone ciertas demandas y condiciones: el pasado es recreado desde un nuevo "imaginario"145 sobre la violencia aportado por las experiencias de la última dictadura y desde un renovado código lingüístico que incluye palabras como "obediencia debida", "desaparecidos" entre otras, y desde el conjunto de problemáticas que hacen al debate de la posdictadura.

La experiencia de las últimas dictaduras en el cono sur provocó una doble necesidad: un primer paso tendiente a "representarlas" y una segunda instancia dirigida a "interpretarlas" y reflexionar sobre ellas.

Una serie de dispositivos lingüísticos se ocupó de representar lo que resultó un modo, sin antecedentes, de violencia impartida desde los centros del Estado. Si bien América Latina fue escenario propicio a las

145 Utilizo este término en el sentido más literal en tanto conjunto de imágenes, pero también apelo a su capacidad "representativa" como dispositivo identitario. 
dictaduras militares en su corta historia independiente, estas últimas se perfilaron como un fenómeno diferente, un corte con respecto a las anteriores. Y no sólo porque compartieron una geografía, el cono sur, un lapso de tiempo similar situado entre $\operatorname{los} 70$ y 80 , sino sobre todo por la implementación de un sistema de violencia estatal de dimensiones y características inéditos en su experiencia histórica.

Este carácter inédito -junto con una política que operaba en las sombras y cuyas acciones sólo fueron conocidas íntegramente por la opinión pública recién con la apertura democrática- provocó la necesidad de "representar" cabalmente y en detalle lo ocurrido, describir sus agentes, las prácticas del terror, los espacios de detención de las víctimas, etc. Para ello resultó indispensable elegir una serie de términos y renovar el significado de otros (por ej. rehenes, mártires, roperos, penal, calabozo, desaparecidos, traslados, capucha, etc.), ordenar imágenes, construir nuevas secuencias (secuestro/penal /torturas /traslados /calabozo /muerte, fuga o liberación). De este modo se llegó a confeccionar un imaginario con el cual la sociedad pudo identificar con señas particulares a las últimas dictaduras del cono sur.

El espacio en el que comenzó a perfilarse este imaginario fue, fundamentalmente, el del testimonio (volcado en las diversas instituciones de derechos humanos y en la prensa internacional) que surgió en el interior de las dictaduras como un lugar de resistencia y de reclamo frente al silencio del Estado y la ineficacia de la justicia. Con la apertura democrática los testimonios llegaron, a través de los medios masivos de comunicación, al gran público espectador, lector o auditor, describiendo con minuciosidad, con los detalles pertinentes y en toda su amplitud, la estructura del terror estatal.

Si bien fue el testimonio el género privilegiado en el cual se edificó el "imaginario de la dictadura", éste impacta en las novelas 
históricas. De un modo general podemos decir que se relee el pasado del siglo XIX utilizando materiales del conjunto de estas imágenes. Así como el testimonio crea un nuevo código para relatar el accionar del terrorismo militar, las novelas históricas buscan describir aquellos elementos que en el pasado caracterizaron con sus propias modalidades el entramado de la violencia estatal. Se destacan, en especial, dos series: las escenas de torturas y la aparición de cadáveres insepultos, muertos que hablan.

En varias novelas abundan las descripciones de torturas. Su práctica se detalla, por ejemplo en El príncipe de la muerte, en el caso del sospechoso Rudolf Runitz, un vienés detenido por el policía italiano Peduzzi en Italia y sometido a torturas bajo el doble cargo de traficante de negros y asesino de Pomerin. Las sesiones de tortura se describen con un doble código, el científico hace de ella una "operación quirúrgica" con su instrumental adecuado, "complicada mecánica de filos, torniquetes, tenezas y agujetas", mientras el código culinario apela al imaginario del hechicero de raíz indígena o africana de América Latina que prepara "menjunjes" con "raíces traídas de América, las cuales, administradas de manera conveniente y en las dosis correctas, provocaban en los prisioneros delirios y alucinaciones, complejos de culpa y terribles remordimientos espirituales, obligándolos en no pocos casos a confesar sus abominaciones" (97). En La fragata... la escena de la tortura a la que Babo es sometido no se limita al cuerpo, violenta su dignidad, este rasgo se reitera en la ofensa cometida contra el protector de esclavos.

El período del militarismo de Latorre está abordado, no desde la descripción del dictador, sino desde sus sicarios, aquellos que despliegan en la oscuridad de la noche la otra cara de la política modernizadora del coronel. Una secuencia se hace paradigmática en estas novelas: la emboscada nocturna, el anonimato de los agentes, las sesiones de tortura en el salón de mármol del Cuartel de Cazadores, minuciosamente descritas y la posterior desaparición del cuerpo arrojado al río. Cito una 
descripción de El archivo de Soto: "En las fondas, en los callejones, en la soledad de los muelles donde sopla el viento y se borran las voces, sombras sigilosas se encuentran y transmiten mensajes. Dan sus nombres. Dan la cara. Se comprometen por cincuenta pesos, pero no son nadie. Los que mueven los hilos permanecen ocultos" (121). Además del interrogatorio a Carlos, la práctica de la tortura recibe una detallada descripción en el caso de los presos políticos del Paraguay acusados de conspirar en contra del presidente López. El "cepo de guasca", la "uruguayana", el "cepo colombiano" hablan de una práctica compleja y desarrollada.

Una cinta ancha... reitera el mismo encadenamiento que va desde la emboscada nocturna hasta el cadáver en el río, lo que sí se modifica es el destino final del cadáver, devuelto a la costa por las aguas, como en los casos de los comandantes Felipe Frenedosos y Lucas Bergara. ${ }^{146}$ Los cuerpos muertos vuelven para contar su historia y pedir explicaciones. La presencia de los muertos, de las voces de aquellos que fueron víctimas de la violencia del Estado latorrista o de los degüellos del Goyo, asesinados en la oscuridad y el anonimato, nos reenvían al período de las dictaduras del 70. El imperativo de la memoria y el reclamo de una explicación por sus muertes son los intereses que movilizan a estos aparecidos. En $\mathrm{El}$ príncipe de la muerte, también los muertos se niegan a permanecer en el olvido y reaparecen en la conciencia de Montenegro -"Era cierto lo que alguien le había dicho alguna vez: los muertos resultaban más difíciles de olvidar que los vivos" (231)- para ingresar en la historia.

Si el testimonio es el lugar privilegiado para describir la dictadura, la novela histórica prefiere indagar y reflexionar sobre sus causas y consecuencias. Si el testimonio tiene su lugar de enunciación en

146 Los cadáveres aparecidos en las costas del Río de La Plata han sido una constante durante la dictadura. En El vuelo de Verbitsky (Bs. As., Planeta, 1995) el capitán de corbeta (R) A. Scilingo narra de qué modo se arrojaban, con su propia participación, a las víctimas adormecidas desde los aviones al Río de La Plata. 
el interior de la dictadura y ello determina su carácter de urgencia dirigido a encontrar a las víctimas; en cambio la novela histórica, cuyo auge se da en la posdictadura, extrae de este momento de enunciación su principal significación. Tanto las características del subgénero -novela históricacomo del momento de su enunciación -posdictadura- parecen complementarse otorgando a la escritura la "distancia" necesaria para al reflexión. De este modo la novela histórica prefiere indagar desde una doble distancia -el pasado y la reflexión- la experiencia de la dictadura.

La apertura democrática procuró dar algún tipo de respuesta a lo sucedido e inició una serie de debates en torno a temas, algunos anteriormente analizados, como la fractura de la identidad, la validez de las democracias, las causas y los antecedentes de la reciente dictadura en la historia, la recuperación de la memoria, el fuerte peso del sector militar en la factura de la historia nacional, la obediencia debida, el juicio a los militares, entre otros. Estos debates se proyectan en las novelas históricas hacia el pasado, en un intento, suponemos, de encontrar sus antecedentes y disipar su carácter ominoso, presentando una cadena cuyo último eslabón cierra un ciclo.

En primer lugar es la dirección de la política del Uruguay por la casta militar durante el siglo XIX lo que estas novelas ponen en escena, por ello seleccionan tres momentos y tres diferentes tipos de militares: el héroe de la independencia se convierte en el brazo exterminador de los indigenas y pierde su dimensión heroica para volverse un personaje trágico. Los caudillos, los cuales al poco tiempo de iniciarse la independencia sostuvieron una serie de guerras entre divisas para acrecentar su dominio, y finalmente la figura del dictador Latorre quien cierra este recorrido por el siglo XIX instaurando la paz y la modernización del país bajo un gobierno autoritario. Si bien ninguna de las novelas históricas coloca como personaje principal a estas figuras (rasgo presente en la tradición latinoamericana del subgénero que se 
quiebra en este corpus, salvo en la novela de Hamed), ellas manejan el poder detrás de los personajes principales (Bernabé Rivera, Montenegro, Santos, Tajes, el Goyo Jeta, etc.). Otro es el caso de Artigas, que trabajaremos a partir de la novela de Amir Hamed.

La doctrina que sostiene el sector militar es puesta a foco a partir de las teorías sobre el exterminio total del enemigo. Ya la hemos visto en ¡Bernabé, Bernabé!, pero también se reitera en En una cinta ancha... La lógica de la aniquilación no admite prisioneros, los degüella, "y nadie perdona a nadie. Se gana o se pierde (...) Y aprendí que cuando uno gana, no debe dejar rencores que vuelvan por uno en el día de mañana" dice el Goyo Jeta (236). Dos pivotes históricos, Quinteros y Paysandú, ejemplos de la práctica de blancos y colorados, obedecen a la misma lógica de la traición y la destrucción completa del adversario.

La "obediencia debida" ( $\tan$ discutida en la posdictadura) como una ley que rige el sistema jerárquico de los militares y no juzga las dimensiones éticas de sus actos, aparece extensamente discutida, como vimos, en ¡Bernabé, Bernabé!. En Una cinta ancha... el tema de la "obediencia debida" es uno de los ejes que sintetiza el modo de operar del sector caudillista-militar. Sólo que aquí sí hay una condena de esta práctica. El tema aparece inscripto en una recurrencia temporal que apunta obviamente a vincularlo con la última dictadura:

"y entonces el sable que cae, al sol, como una hoja, y refulge y corta el aire, como si matara, pero no mata: no mata por sí mismo, no hiere, pero manda matar, ordena, igual que otro sable siete años antes: no el mismo pero quizás el mismo, que también cayó y ordenó y mató por otros, los que obedecieron. Cayó como un golpe pero no mató de un tajo, mató ordenando: no al hombre sino al soldado, al ente obediente formado por años en 
jerarquías y superioridades y educado en acatar al solo grito de mando (...) El sable cayó hiriendo la claridad, igual que siete años antes, igual que siempre (...) y el mecanismo de la obediencia se disparó primero y la luz del sable en la caída arrastró la educación militar, la disciplina (...)" (106)..$^{147}$

El tema del juicio -otro de los debates centrales de la posdictadura- aparece de modo reiterado en estas novelas. La recurrencia de escenas de tortura y crímenes clandestinos llevados a cabo por los gobiernos cuestiona, en definitiva, el ejercicio de una justicia que no se realiza por los canales institucionales -el Poder Judicial- propios de un Estado democrático. El archivo de Soto aborda directamente el problema de la justicia y su relación con la ley. Dice el narrador: "Los propios amigos del coronel Latorre no saben dar razón de cómo, teniendo en la mano la prueba palpable de la culpabilidad de Soto, no se difirió a la justicia el castigo del reo, habiendo recurrido el Gobernador a un delito atroz que puede afectarlo en su próxima retoma del poder. El tiempo dirá si esta fatal determinación fue debida al ímpetu de la pasión personal" (141). El tema de la justicia al margen de las instituciones, curiosamente se presenta por primera vez en esta novela en boca del Secretario de Latorre, Don Francisco Xavier de Acha, quien le comenta a Carlos a propósito del fusilamiento y ahorcamiento de un negro a manos de la policía: "Ahí está. Pero, ¿y si no lo era [culpaple]? Si le cargaron una culpa ajena...¿QQué sería de nosotros si cada comisario pudiera fusilar o ahorcar a su antojo?" (115). Pero es el mismo De Acha quien justifica la dictadura de Latorre con una cita de Sarmiento: "No trate de economizar sangre de gauchos, ése es un abono que es preciso hacer útil al país. La

147 El tema de la obediencia debida se reitera a propósito de Nicanor Zuleta, -"que mataba a quien fuera: pero sólo obedecía esa voz; no a leyes ni legajos, no a principios ni tratados ni doctrinas ni reglamentos"- enviado por Gregorio Suárez a asesinar a Venancio Flores, p. 202-203. 
sangre es lo único que tienen de seres humanos" (117). La figura de Sarmiento se cuestiona en casi todas las novelas con el mismo propósito de presentar la "barbarie" de la civilización.

Este tema recibe un tratamiento complejo en ¡Bernabé, Bernabé!. Josefina, acorde a lo que en una entrevista expresó T. de Mattos, se niega a dar una sentencia: "No voy nunca a ser juez" (58). Su principal actividad, sin embargo, nos coloca en los preliminares de un juicio: la recolección de documentos, la conversación con los testigos, la verificación de las informaciones por medio de fuentes confiables, las reflexiones en torno a los argumentos de la defensa y la acusación. Por otro lado, si Josefina se niega a la tarea que corresponde a la justicia, el juicio institucional no es descartado. Por el contrario, el editor MMR instala el tema a partir del juicio de Nuremberg y lo defiende "(...) los perpetradores de los crímenes que hoy repudiamos y cuyo castigo tanto nos congratula" (25).

En Una cinta ancha... el juicio también aparece desplazado hacia el futuro. Salamanca le advierte al Goyo Jeta sobre el juicio de la Historia, pero el texto se detiene en los momentos previos: cita los documentos que apoyan diferentes puntos de vista sobre los hechos. La mano de la venganza asesina a Montenegro y sustituye a la justicia en $\mathrm{El}$ Príncipe de la muerte. Pero más allá de estas tematizaciones, el juicio, como reiteraré más adelante, permea la forma del relato -el entramado en términos de Hayden White- con caracteres típicos del policial. 


\section{EL ARTE DE BORRAR EN ARTIGAS BLUES BAND DE AMIR HAMED}

\section{Escritura/ retroescritura}

En 1994 Amir Hamed publica Artigas Blues Band. Cuatro años más tarde reúne en Retroescritura (1998) una serie de ensayos escritos desde 1992, varios de los cuales aparecieron (entre 1993 y 1995) en "La República de Platón" -suplemento cultural del diario La República.$^{148}$ A ello hay que añadir otra serie de artículos publicados en Insomnia. Abordar, entonces, su novela requiere el paso previo de indagar las reflexiones vertidas en estos artículos.

Antes de ingresar a sus textos, quisiera decir que su escritura parece asentarse en una doble ascendencia: lo "ilegible" y lo "mutante". De allí las dificultades y complejidades para cualquier interpretación que inevitablemente cierra sentidos a los que su escritura siempre parece escapar.

A la categoría de "experimentación" heredada de la vanguardia, Hamed prefiere las de "metamorfosis" y "mutación" para cercar su idea de escritura. ${ }^{149}$ Aquella remite al imaginario técnico siguiendo la lógica de lo nuevo; éstas intentan mostrar que el arte, lejos de seguir los imperativos de cualquier técnica, señala "las lagunas de la tecnología, abriendo así nuevos parámetros". Desplazada al arte, la técnica se traduce

148 Las citas corresponden a Amir Hamed, Retroescritura, Montevideo, Fin de Siglo, 1998.

149 Para el análisis que aquí llevo a cabo de las obras de Amir Hamed, utilizo una serie de categorías provenientes del postestructuralismo -en especial Derrida, Deleuze y Guattari- pero que evito citar para no trabar la lectura. Hamed se coloca en esta perspectiva para activar desde allí una crítica no sólo al régimen militar, sino también al proceso democratizador y sus políticas culturales. 
en una poética que, en la vanguardia, dio lugar a los istmos segregadores de dogmas antepuestos a la creación, obstáculos a "una radiante y exigente percepción del mundo". ${ }^{150}$

La "experimentación" es -para Hamed- una práctica que vuelve sobre sí misma, desata fuerzas "sin saber cómo dirigirlas". En cambio, la "mutación" si comienza con un mismo acto subversivo, reconduce las fuerzas hacia un "surco". ${ }^{151}$ Estas oposiciones parecen poner en juego más de lo que dicen: se trata de dos diferentes códigos, dos modelos científicos que subyacen a dos poéticas, dos percepciones del mundo que marcan lo que va de principio del siglo XX a su final. Como sabemos, el postestructuralismo, especialmente Deleuze y Guattari, junto con las teorías del caos y los fractales provocaron un vuelco en las teorías y en el imaginario científico con que las poéticas se actualizaron.

El arte como mutación encuentra -para Hamed- su texto clave, su origen y paradigma, en las Metamorfosis de Ovidio, no sólo porque su obra describe diversas metamorfosis, sino además porque expone el proceso de construcción narrativa como una sucesión de mutaciones. El texto se abre con el Caos que no es "más que masa tosca", punto de partida de las mutaciones que en su texto abarcan desde el inicio del mundo hasta el presente del siglo I; y remite también al proceso de escritura que comienza como un conjunto de "gérmenes discordantes" para arribar a una "meseta". Así, "Ovidio es la exigencia de lo que muta: narración". El proceso se extiende a las lecturas y reescrituras de las que será objeto: "No ignoraba que otra mutación ya se lo estaba llevando: nosotros -la lectura- que por milenios lo seguimos torsionando, no lo dejamos descansar".

\footnotetext{
150 Amir Hamed, "Vanguardia y dictadura", en página web.

151 Amir Hamed, "Forma, resistencia, indigestión", en página web.
} 
Las Metamorfosis de Ovidio -en tanto proyecto sideral- sin embargo, difieren de la escritura del presente, atravesada por mutaciones que pervierten y desvían cualquier "gran obra" al contagio de un virus: "el diablo o un virus, un programa antojadizo, la impalpable piratería de la red o nuestra impericia amenazan volatilizar nuestras palabras. Pareciera que el gremlin que perturbó a Descartes juguetea en las computadoras, saboteando esa gran obra, esa incisiva reseña, la columna candente que no llegamos a escribir". ${ }^{152}$

La mutación es a la vez signo de lo "real" -"Devenir, volverse algo distinto de aquello que se está siendo parece el orden natural de las cosas"-; ;53 y condición del "verdadero sentido de la literatura", ya que revela y pone en escena la ley mutante del mundo. Configura el centro de la escritura como práctica nómada que se enfrenta a los códigos cristalizados: "Se afirma que la naturaleza procede por ensayo y error, que las especies realizan tentativas de mutación que, en contacto con el entorno, aprueban o descartan. Igual hace el arte: debe enfrentar la resistencia de aquello que lo rodea -los códigos del público, la consistencia y maleabilidad de los materiales, el paredón o la herencia de obras que lo anticipan. Al pastorear la fuerza, el artista va tentando por donde se abren resquicios, dónde la resistencia se vuelve vulnerable, cuándo y cómo ese empuje, al desbaratar la materia va haciendo sentido". ${ }^{154}$

Si, dijimos antes, Amir Hamed sustituye la experimentación por la mutación, este giro tiene raíces profundas que advierten sobre el pasaje de un imaginario técnico de la modernidad a otro biológico de fin de siglo. Restroescritura marca el tránsito del uno al otro. La ciencia como

\footnotetext{
152 Amir Hamed, "Del caos o prólogo del mundo", en página web.

153 Amir Hamed, "Ovidio o de cómo deja de ser el mundo", en página web.

154 Amir Hamed, "Forma, resistencias, indigestión", en página web.
} 
disciplina clave de la modernidad ha procurado ordenar, explicar y sistematizar lo real. El filósofo de la ciencia, a cargo de este orden, ocupa el lugar de "un buen Dios, un padre, un señor superior, serio y responsable" (165) y su gran representante, Hegel, instauró el Espíritu como principio organizador de la historia.

El fin de siglo arma otro escenario. El mundo virtual detiene la progresión del conocimiento tensionada hacia el futuro para convertirla en un presente del "Saber Absoluto" y ofrece una disponibilidad de dispositivos -"órganos, chips, tornillos, genes"- como piezas que invitan a un nuevo juego: "Sé todo lo que hay que saber: no me resta entonces sino inventar y jugar, volver sobre lo hecho, corregirlo, modificarlo, introducirle minúsculas variantes" (166). El duende, una figura menor, ha sustituido en este juego al Espíritu y desobedece -como el ángel caído- al padre. La clausura del futuro como proyección del Espíritu en su autoconocimiento da lugar a una revisitación del pasado, arcilla dispuesta a las mutaciones del duende: "rever, corregir, reparar el pasado".

Hamed postula dos hechuras del duende: el arqueólogo posestructuralista y el cuántico quienes proyectan dos operatorias sobre el pasado. Entre los arqueólogos, Derrida deconstruye y critica los discursos del pasado mientras Foucault arqueologiza sobre las fallas y discontinuidades de la historia que el padre olvidó. Hay una voluntad de reparar rescatando una "historia secreta" silenciada en las fábulas del progreso y la evolución del Espíritu: "Es desatar una historia más infame como clave de interpretación (y de deconstrucción) de la cultura europea" (167). Frente a ellos, Deleuze y Guattari ofrecen "una revisión incesante en una especie de presente homeostático" (167).

Pero -y aquí reside la propuesta de Retroescritura- si el arqueólogo posestructuralista deconstruye el pasado para desmontar sus "fallas" y "discontinuidades", recuperando la historia secreta de las 
barbaries (y con ello "prepara el espacio de un arrepentimiento o de una revisión penitente"); el cuántico visita el pasado para actualizarlo desde los juego que gustan al duende.

¿Cuáles son las reglas, las condiciones de este juego con el pasado?

El agente de ese viaje al pasado es el duende, figura diabólica, o el "hermano mayor" quien también desobedece al padre y "psicopatea" a sus hermanos erosionando sus convicciones. Ambos carecen de un mayor que los sostenga y legitime. Si el Espíritu sancionaba la ley progresiva de la historia y ordenaba el cosmos en esa grilla, el duende desarticula los estratos, las regularidades, desune para mezclar y confundir. El "virus" -factotum de múltiples mutaciones- es la "estrategia", ataca a la máquina del Estado pero lo hace a través de la peste y los microorganismos ("terrorismo nomádico, organizaciones transnacionales, narcos, fanáticos, gangsters").

Retroescritura es una máquina de guerra contra el estado y sus variantes, el Espíritu, la ciudad, las letras sedentarias, las gramáticas lineales, los géneros literarios. La Retroescritura como máquina de guerra pone en juego dos mecanismos: el "RE" es "volver a presentarse" (164), revisitar el pasado para activarlo desde el "TRO". El "TRO" es la práctica mutante frente a ese pasado, el efecto de dispersión y desviación inscripto en el juego del cuántico. Esta práctica desvía el sentido del logos del padre, lo pone a vagabundear en sus derivaciones dispersantes y en sus reagrupamientos advenedizos, desarma las distinciones genéricas para confundir sus gramáticas, mezcla los materiales nobles e innobles, cultos, populares y captura al pasado para instalarlo en el presente, lo despreteriza en el juego citatorio. Dice Hamed:

"Retro: Re de volver a presentarse. Pero se da un Tro de volverse, de dar vueltas, de dispersarse. Un tro de disipación, de obstinada ausencia 
de norte -o de pasado. Un tro que hace del ayer un juego, propio de un lugar sin pretérito. Un tro básicamente advenedizo, semoviente o nómade, vagabundo o errante, como se quiera, cuyo sitio único está fuera de todo sitio, incómodo con la mayoría de los géneros. (Letra que se muda o letra mutante). Un tro que imita poco al mundo, que apenas lo deriva." (164)

La textura de Retroescritura despliega un imaginario y lo varía. No hila un conducto lineal, dispone una trama de figuras que se entreveran persiguiendo haces de significaciones. Captura una imagen del presente y va acoplando a su alrededor otras imágenes similares o desviantes, del pasado. Retroescritura el pasado desde la mutación. ¿Cuál es, entonces, este imaginario de y sobre la escritura? En cada sección de las quince que forman el libro se apunta a un elemento -o a varios- de su poética.

Comienza con la muerte de Alien a manos de su madre, la teniente Ripley, metáfora de las disoluciones de los restos de modernidad operadas en el fin de siglo y signo del vacío a que dieron lugar. Alien es la primera figura de una larga serie de "ogros" que el texto consigna, ocupa el lugar de la alteridad más absoluta, lo irreconocible que acecha "en el umbral" de lo nuevo. Sin figuras paternas, con una madre que rechaza su engendro, este film pone en escena la retirada y el vacío del Padre. El constante deambular por los bordes del Universo desarticula el viaje lineal de las teleologías.

En ausencia del Padre, desembarcaron en los años noventa los "hermanos mayores" para pilotear "la ingrávida nave de los desencantos". Descreen del futuro y sus épicas teleológicas, son "desestabilizadores" que operan desde el terrorismo viral carcomiendo los pilares del sistema que fingen sostener (desde este lugar Hamed analiza la figura de Bill Clinton como un "hermano mayor"). 
La vacancia del "Gran Padre Blanco" da nacimiento al mestizaje global y pone en acción la "máquina caníbal y recicladora", la lógica de los hipervínculos que ofrece el pasado para el menú del día, la emergencia de lo "prepóstero" como desarticulación del sentido -la flecha- del tiempo tendido hacia el futuro como telos y hacia el pasado como genealogía, y el inicio de la retroescritura como escritura del Alien sin ojos ni mirada.

A Alien le sigue un bestiario de monstruos como sujetos de la retroescritura que introducen lo demoníaco, la extranjería en la lengua madre, el crimen en las tablas de la Ley, lo monstruoso en la naturaleza, la Edad Media en la nueva era: Frankestein, Drácula, la Pantera Rosa, el Golem, Quasimodo (son los devenires-animales, el devenir monstruo de la letra). Es la escritura de la horda que asalta la ciudad.

En "La madre del género" se anuncia el devenir de la lengua extranjera en la lengua materna; la pérdida de los ancestros en los dialectos huérfanos, bastardos: así Garcilaso de la Vega renovó el castellano desde la lengua italiana, Góngora lo latinizó. También se anuncian las mutaciones de géneros como el tango ("armado en base a residuos de la literatura romántica y a ritmos de negros").

El espacio de "Metrópolis" se escinde entre el adentro y el afuera de la ciudad sitiada, los ciudadanos y las hordas de bárbaros que los hambrean. La escritura -mejor, la voz- se fragua como una máquina de guerra nómada, bárbara que asalta los muros de la ciudad. El comienzo cita a Homero: la épica como canto de los sitiadores de Troya es la voz de los nómades confrontada a la escritura de los sitiados. Entre los habitantes de Metrópolis se encuentra San Agustín quien compuso una "ciudad para Dios"; Platón, otro interno, es indiferente al asedio del afuera al escribir su República; también Virgilio funda con Eneas a Roma desde el adentro. La civitas dei agustiniana pasa a América con Colón 
quien "ha encontrado a sus bárbaros". Las ciudades se fundan en la escritura con sus murallas que desalojan a los nuevos bárbaros. También en América, para Hamed, Ercilla escribe desde la ciudad; en cambio México-Tenochtitlan conserva algunos versos de los sitiados aztecas. Finalmente hoy las "hordas" bloquean las autopistas de entrada a México y las metrópolis se duplican en un mundo subterráneo (como en Metrópolis de Fritz Lang) o son asaltadas por los inmigrantes, los nuevos bárbaros.

El buey y el camello reiteran en otra clave la oposición sedentario/nómade en "Escritura de buey (La máquina de buscar la sombra)". El buey con su arado "hace el ordenado surco que llamamos cultura" y escribe "linealmente la historia" (86), de izquierda a derecha, de "occidente hacia oriente", busca la sombra. Es, también, una escritura castrada, "porque para escribir debemos castrar" y "hacer de la bestia cultura" (87). Una de sus variantes, el "bustrofedón", diseña una huella en zig zag (la vuelta del buey). En cambio el camello se mueve en el desierto (espacio liso, no estriado por los surcos del arado, en términos de Deleuze y Guattari), es "incapaz de acarrear un arado y, además, sexuado "cargado de deseo". Su carácter nómade -"parece no perseguir nada"- y su escritura "ciega" lo hacen deambular a "zurda y diestra". Esta oposición se resuelve en un mutante, El Quijote, "brote de un camello fantasma que se ha apareado con un buey", producto de la "pluma siniestra" de Cide Hamete y de la "letra diestra" de Cervantes.

"Recalentamientos" opone dos modelos de autómatas inventados sucesivamente por Dédalo y Leonardo da Vinci. El primero creó el bovino donde se ocultó Pasifae para copular con Poseidón, una vez nacido el Minotauro construyó un laberinto para guardarlo y finalmente a Talos para proteger el laberinto. El laberinto es escritura "bovina, bustrofedónica, sombría" ya que con el hilo de Ariadna, Teseo podrá leerlo. Para facilitar la huida del laberinto (del hilo del discurso) le diseña 
a su hijo Ícaro "alas de cera que le permitirían volar", pero fracasa cuando las alas se derriten con la proximidad del sol. Leonardo crea no desde la matriz lineal del discurso, sino desde las refracciones de la luz y los espejos que lo miran y retrovierten con un punto de fuga. Concibe una "máquina de vuelo" que deviene en murciélago, en vampiro, símbolo por excelencia del retroescritor.

En "Nadie me quiere" Hamed pone en práctica uno de sus juegos favoritos: desarticula una organización, un organismo y secciona sus partes eligiendo cuidadosamente ciertos elementos. Comienza con el "ojo" de Schwarzenegger en Terminator y lo pone a deambular por otras textualidades. Se trata del problema de la escritura y sus cegueras. Schwarzenegger en el baño acaba de arrancar su propio ojo malherido para volver a salir en busca de la madre del futuro y exterminarla. Esta metáfora dispara una serie de conexiones que articulan fragmentos: el ojo, la máquina de guerra, el deseo de matar al padre o a la madre son los dispositivos necesarios para la escritura. Los vectores que ramifican las metonimias son: los Cíclopes de un solo ojo -"máquinas de guerra" (fraguan y funden metales para construir las armas)- junto a los Titanes y Gigantes quienes "se rebelan contra su creador". En la saga de Odiseo, éste enceguece a Polifemo, le enseña a leer y escribir cauterizando su ojo, volviéndolo ciego. Sólo cuando el ojo es herido, puede comenzarse a escribir. El mito platónico de la caverna sólo muestra sombras y cuando salimos la luz "hiere nuestros ojos y nos vuelve ciegos para percibir las sombras" (96). "En la colonia penitenciaria" se narra la hybris -y la imposibilidad- implícita en el intento de leer la Ley a través de la escritura de la máquina que a última hora se desbarajusta y "el mensaje es indescifrable, sanguinolento y roto" (97). El que busca desentrañar la Ley, deviene culpable. Edipo, a continuación, retoma la escena kafkiana para arrancarse los ojos en reconocimiento de su culpabilidad. El relato se cierra con una película del presente, "The Silence of the Lambs", en la 
cual la salida de la caverna provoca hambre, pero nadie puede saciarlo ("Nadie puede decir": aquí el "Nadie" remite al nombre que Odiseo le dio al Cíclope y, obviamente apunta a la muerte del padre como fundador de la verdad, afirmación que reúne al resto de las historias) .

Entonces, dos cuestiones me interesan de este capítulo. Por un lado la escritura del propio Hamed y sus estrategias: desde el presente -y a partir de Terminator- selecciona un grupo de signos (el ojo; la máquina de escritura; la necesidad de alcanzar y/o matar al padre-madre-Ley) que conforman un dispositivo para leer el resto de los textos de la cultura. Pero también cada relato configura una instancia, un momento (comienzo, desarrollo de temas, variaciones sobre los mismos, coda) de una narración mayor armada como un tejido de retazos que se van superponiendo y cuyas conexiones se evitan. Por otro lado el texto habla sobre la escritura para decirnos -suponemos- que sólo es posible leer aniquilando un ojo, desde las sombras, desde las cavernas, sin procurar apresar la Ley ni descifrar la Esfinge ya que "Nadie" es quien habla.

"Aires viejos (groserías, delicadezas)" dispone una constelación en torno al hambre, el banquete y el canibalismo. Se trata de la escritura a partir de la carne y no del Espíritu, sospechamos. El ojo malherido de Polifemo levanta en el negro de la gruta su párpado como una "membrana" (99) que luego deviene "miembro", "pene", "the pen". Es, además, un ojo "famélico" que proyecta su "hambre" en los diversos banquetes que el texto persigue: la obertura es la película "Delicatessen" cuya "carnicería" aparece como el resto de una gran catástrofe (¿la carnicería, la carne como sobreviviente de la muerte del Espíritu?). La imagen elegida muestra las boletas de los créditos de la película prendidas de los jamones, pescetos y cuadriles, en tanto metáfora que señala a la carne como "única garantía fiable" de la escritura. 
Sigue el banquete de Platón donde se sirve una frugal comida, un "poco de aire" -en Platón no hay antropofagia. "The cook, the thief, his wief and her lover" de Greenaway ofrece como plato el cuerpo de Michael relleno de páginas que Mr. Spica deberá comenzar a comer por "el pene", en conexión con el pacto entre Abraham y Jehová, que incluye la circuncisión como principio de la escritura de la Ley. Entonces: la escritura emerge a partir de la mutilación del pene y su transformación en "the pen". "The silence of the Lambs" pone en escena la antropofagia como un nuevo nacimiento que se completa con dos citas: la última cena cristiana y el mito de Zeus quien, superando el sacrificio cometido por sus ancestros (Cronos y Urano comieron a sus hijos), pare a Palas Atenea desde su frente. El canibalismo adviene un proceso de escritura: "siempre que cito a alguien es porque me lo estoy cenando". A continuación, en "Fried Green Tomatoes at the Widi's Stop Cafe" la escritura del criminal narra el cuerpo del delito que se devora en el acto de antropofagia (la novela El perfume, de Patrick Süskind). La escritura se erige desde la carne, a falta de otra garantía que la sostenga y termina por revelar al escritor como un asesino, un caníbal, un antropófago.

"EXP.P (PSICOANÁLISIS PARA PASTORES") es el único apartado más cercano a la ficción. Apunta a la creación de la Máquina de guerra. Platón ha arrojado al ostracismo a los poetas, a los extramuros de su Ciudad-Estado gobernada por "Las Más Altas Ideas". Pero los exiliados inventan una "pastoral" a partir de la factura del "Idilio" de Teócrito, una nueva máquina de guerra para asaltar los andamios de la República. Este idilio, bucólica o pastoral esgrime como armas la defensa de "la vida natural" en contra de la ciudad y de la utopía que es en realidad una heterotopía. Sus versos dispersan la peste, el virus de la sífilis descubierto en 1495, año sacudido por una serie de cambios: el descubrimiento del Nuevo Mundo, la invención de la imprenta y de la bala de cañón. Los tres nuevos inventos se conectan entre sí para hacer de 
la escritura una máquina de guerra cuyo virus sifilítico dispersa y deriva los sentidos en una incesante mutación nomádica inaugurada en el espacio "americano".

Retroescritura es a la vez una poética -reflexión sobre la escritura- y una puesta en práctica de esa poética. La lengua de Amir Hamed es la inscripción de múltiples lenguas extranjeras en la lengua madre del español americano: desde giros sintácticos griegos y latinos, el uso de epítetos, el arcaísmo de un castellano barroco ("en combate -parece- murieron en miles más de doscientos sitiados", 82), las citas en inglés, francés, alemán, italiano, griego y latín hasta la inclusión del lenguaje de la computadora. La escritura combina prosa, verso, letras de tango, rock. El espacio de la hoja está en continuo movimiento intercalando párrafos con estrofas, versos, notas a pie de página que abarcan toda la página, tachaduras de lo escrito, zonas que transcriben el espacio de la pantalla de una PC. Las citas entrecruzan un amplio haz de textualidades que van desde la cultura de los medios masivos y la informática a Homero, Virgilio, la Biblia, San Agustín, Baudelaire, Poe y lo hacen desde la "frotación" de los textos como fuga de su recto sentido y reagrupamiento desviante. La narración -el hilo del relato-, tal como ya vimos, se arma en una sucesión de citas a modo de patchwork. Hacia el final, Retroescritura se cierra con una coda escrita por Sandino Núñez.

Ahora podemos preguntarnos de un modo directo y contundente ¿A dónde apunta Amir Hamed los cañones de su máquina de guerra? Artigas Blues Band puede ser una respuesta. 


\section{Artigas Blues Band de Amir Hamed}

Pues no deis 1, que resonará al infinito

César Vallejo

Artigas Blues Band resulta una retroescritura de la historia de Artigas que monta desde la "leyenda negra" una máquina de guerra contra el grafo sedentario. Cita un ciclópeo conjunto de textos sobre Artigas proveniente de las fuentes más diversas (desde los liberales argentinos a las canciones de Rada) y los pone a "frotar" en una textura desbordante. Narra alternativamente varias historias que se deslizan, se cruzan, interfieren entre sí, se mezclan.

La novela se inicia con la "cachetada justiciera" que una prostituta propina a un macró en Plaza Independencia bajo la estatua ecuestre de Artigas, quien entonces decide iniciar sus andanzas acompañado por su fiel compañero Ansina. Pero esta escena es parte del sueño de Ariel, producto de la pérdida de un trabajo académico que un virus búlgaro destrozó en la pantalla de su computadora. Ahora se decide a escribir una novela sobre el héroe oriental. El origen de la escritura, de la literatura, se encuentra en el sueño como alternativa al mundo académico.

El relato discurre, entonces, a través de dos vectores: la historia que ahora de nuevo Artigas emprende reescribiendo -retroescribiendo- su propio pasado, y las aventuras de Ariel, Gustavo y Pedro. Ariel -en Nueva York- decide sabotear un congreso universitario con la ayuda de Gustavo y en nombre de Artigas. Al mismo tiempo inicia su novela sobre el héroe. Desde Montevideo, Pedro organiza una célula subversiva llamada 
"Leyenda Negra", ${ }^{155}$ dispuesta a atacar las estatuas y demás iconos del padre de la patria, y a cambiar los nombres y orientaciones de las calles montevideanas (en un proceso de desterritorialización). De este modo, la narración estará en boca de diversos personajes: Artigas, su compañero Ansina y su amanuense Barreiro junto con Ariel, Gustavo, Pedro y sus respectivas mujeres, Ana, Susana y Leda, en una cronología muchas veces desarmada.

Producto del sabotaje al Congreso universitario, Ariel queda cesante y con sus papeles sobre Artigas decide regresar a Montevideo. En la capital uruguaya ya se ha montado una contraofensiva del gobierno a cargo de Juan José Artola para descubrir y desbaratar al grupo subversivo. Apenas arribado, Ariel es sorprendido por Artola con los manuscritos sobre Artigas. Prisionero, será Pedro -fingiendo apoyar a Artola- quien lo torture hasta convertirlo en un vampiro para finalmente abandonar la ciudad en viaje hacia Argentina. Pero antes Pedro continúa y profundiza los ataques de su banda. Por su parte Gustavo monta a pedido de Pedro una filial del grupo subversivo en el extranjero a fin de extender el accionar corrosivo de Leyenda Negra por varias ciudades europeas. En su meta final, el desierto egipcio, contempla el fin del mundo y el comienzo de una "buena nueva".

En esta trama Artigas Blues Band explora sin distraerse y hasta la exasperación las posibilidades de la escritura. ${ }^{156}$ Nada cae fuera de ella. Las aventuras y desventuras de Artigas trasiegan el interés de su verdad

\footnotetext{
155 Como se sabe, la historiografía liberal porteña, recogiendo todos los resabios de una tradición política adversa al caudillismo, fue consolidando la "leyenda negra" en torno a Artigas, en tanto sinónimo de anarquía y caos social. Mitre y Sarmiento sancionan esta versión en sus textos. La intelectualidad uruguaya rescató desde fines del siglo XIX la figura de Artigas para culminar con dos obras monumentales que lo convierten en el héroe nacional indiscutido: el Alegato histórico (1909) de Eduardo Acevedo y La epopeya de Artigas (1910) de Juan Zorrilla de San Martín.

156 Las citas corresponden a la siguiente edición: Artigas Blues Band, Colonia, Fin de Siglo, 1994.
} 
histórica hacia los avatares de la escritura en una trama que lee "los parajes por que discurrían" como el trayecto de los signos. ${ }^{157}$ Los personajes, de una u otra manera, leales o traidores, no pueden escapar a su condición de escritores. Éste es el hilo que mi lectura propone: anudar en la exuberante textura de Artigas Blues Band las andanzas de la letra, el acontecimiento de la escritura, los desbarajustes del archivo, las figuras del escritor.

El punto inicial de esta aventura se origina en el éxodo artiguista, en el vacío como abandono del principio de realidad y comienzo de la invención, de la ficción: "yo inventé este país cuando me los llevé a todos al éxodo, lo vacié" (13). Lo "real", aun la ficcionalización de lo real, en Artigas Blues Band se nos retacea una y otra vez en un comienzo que, luego nos enteramos, no es más -ni menos- que el sueño de Ariel. A este sueño le sigue la voz de Ariel que habla desde la duermevela del que aún no ha despertado y sólo despertará para convertir su sueño en ficción, que será novela dentro del diario de Gustavo quien asimismo recoge otras escrituras sobre el héroe.

Por su parte, Artigas se convierte en el primer escritor uruguayo en una escena donde se niega a refrendar los límites de lo real: "abandoné el colegio de los franciscanos, después de arrojarle un tinterazo al cura porque me negué a escribir una plana que dijera Non Plus Ultra, porque de haberlo hecho, de haber rubricado esa frase, no hubiera logrado renacer" (13). La escritura se abre a las posibilidades situadas más allá de un pasado clausurado.

157 Resulta complicado dirimir la relación entre la dimensión histórica de Artigas y la reflexión sobre la escritura. De ningún modo considero que Artigas Blues Band conciba el relato de Artigas como símbolo, metáfora o alegoría de la escritura; por el contrario, el itinerario del héroe oriental es un modo de escritura. Éste es, quizás, el mayor quiebre que esta novela ejerce en la tradición del género y en el contexto de novelas históricas de la posdictadura del Uruguay. 
Pero el éxodo no es sólo vacío -o porque es vacío-, destila una sustancia corrosiva para los pretendidos Principios, contiene un virus que ataca a la letra, desparrama la peste que contamina la integridad de los significados. La escritura como virus, borradura, peste y violencia subversiva de la letra es el legado de Artigas: "y cuando decidí morirme, la peste llegó a mis descendientes" (13).

La escritura, entonces, expone la lógica del vacío original que sólo tolera la reescritura incesante, el arte de borrar el padrenuestro artigas para volver a comenzar en el éxodo continuo de los principios, la mutación que vuelve al pasado para dispersarlo. Dos imágenes de la letra: como sangre, semen, flujo menstrual, tinta, en definitiva, el flujo del deseo o como coagulación, cristalización. Apuntan a dos modos de entender la temporalidad: la historia como monumento reitera el pasado en la contigüidad sin distancias de la memoria cincelada en el mármol -con-memora-, es conservacionista o, en el mejor de los casos, tolera un nuevo perfil sólo para reinscribirlo nuevamente en letras de molde. La historia como retroescritura estropea la temporalidad progresiva, despierta al héroe y lo pone a andar, coloca la historia en la apertura indefinible del futuro -"Sí, mi general, todavía hay historia por hacer" (10)- la sitúa en lo posible, contra el principio de realidad, en la ficción "porque hay historia para escribir" (10). Ansina le muestra el camino a seguir "hasta que lleguemos a los parajes donde lo quiero llevar, donde se gestan las pesadillas del prójimo, donde pocos pueden llegar, donde todo lo que no es Historia puede volver a empezar" (14).

Entonces, se trata de desarmar la lógica del monumento, irrumpir para disgregar la letra muerta de la conmemoración, borrar el epitafio del mausoleo: “A pesar de la justicia de nuestro impulso, todos querrán decir que usté está muerto, muy muerto, para eso en la dictadura le hicieron este mausoleo (...) y todos han estado de acuerdo en enterrarlo con 
piedras y tinta panegírica a usté que fue el Anticristo de tantos. Para matarlo lo trajeron a todo este mármol" (11).

Artigas Blues Band desarticula la conmemoración de la batalla de Las Piedras y es Pedro, la piedra, quien la pulveriza en la fiesta, en el juego del truco y del ajedrez, en el baile para escapar a la repetición, para dar lugar al otro ilegible bajo la sugestiva incitación de la letra de Jaime Ross "lo que no te di". La conmemoración como una cita que repite es la huella estéril a la que Artigas quiere escapar "Ya saldrán de eso, se decía Ansina al separarse del general; en todo caso, estaba bien, era un buen pase para salir de la repetición a la que podían quedar condenados" (82). Pedro se niega a asistir al acto escolar de la fecha patria, se niega a la repetición del cuadro de Blanes que asegura la clemencia artiguista y prefiere organizar una peregrinación a Las Piedras para ir "a bailar y a tocar alrededor del monumento". El festejo de la batalla con una fiesta es el principio de la acción subversiva. También Artigas, que se niega a repetir la batalla, prefiere - como los otros- ir al baile para enamorar a Rafaela Rosalía Villagrán: "voy a intentar -por lo menos a intentar- la forma última del destino, que es la felicidad" (82). En sintonía con Pedro y sus amigos, Ariel y Gustavo planean boicotear la conferencia en los claustros de la universidad norteamericana, mientras descreen de la clemencia de Artigas con los vencidos.

Miguel Barreiro, el amanuense de Artigas, quien transcribe sus cartas, pone en escena la figura del copista como traidor. Quien no sabe leer traiciona la índole plural del signo, desconoce, en fin, el arte de escribir. ${ }^{158}$ Miguel Barreiro solía copiar las cartas que Artigas siempre

158 Confrontar la siguiente cita: “Sabría ya el general cuál había sido el dilema del sobrino? Miguel Barreiro, el amanuense que con el punzón de la pluma abría surcos oscuros en el papel para que la voz del general se acomodara en el espesor y negrura de la tinta, para que volara: La operación maquinal de cavar pozos, cráteres en la superficie lunar del papiro, para que el general volara en una carta o se fijara en un documento. A veces, en aquellos tiempos, la operación era tan automática que no era oída por Miguelito, y el general, en los respiros que se daba, terminaba 
dirigía a otros, nunca a él, por eso ignoraba las destrezas del lector, por eso fue incapaz de leer la carta que por una vez Artigas le dirigió a él, convirtiéndolo repentinamente en lector inexperto. Fue su mala lectura la que lo transformó en traidor a la lengua y sentenció su muerte. Pero ahora Miguel vuelve a recomenzar su práctica de copista para convertirse en "escriba", para entender lo que Artigas demandaba de él, para cambiar su destino y el de la letra en la práctica del arte de borrar, para por primera vez cambiar -mutar- una de las palabras que Artigas le dictara y así leer, releer: "Ya tal vez no lo vaya a matar. Si hasta acaso se haya conmovido el general cuando descubrió que Miguel, siempre pulcro, acudía al secante para corregir el desborde de la tinta diseminada con el agua salada de las lágrimas del escribiente. Que nada decía. Ni siquiera tío, yo soy ese que V.E, El Protector reclamó. El que sabe leer. La espalda del general se armaba contra la luz esquiva de la entrada, abandonando el ambiente en donde el escriba se enroscaba, cabizbajo y húmedo sobre el papel, con el secante borrándolo todo, no sin despedirse con una frase: Don Miguel, no se preocupe, seguiremos en otro momento. Una frase que Miguel, recogiendo un papel nuevo e inmaculado acomodó -tal vez por fuerza de costumbre- en letras de su mejor caligrafía, pero que modificó (...)" (130, la cursiva es mía).

Tampoco Barreiro conocía el guaraní, no podía traducirlo y por eso ignoraba la estrecha relación de Artigas con los indios, no alcanzaba a leer las palabras que el general marcaba en la cabeza de sus indios: "Y como sé que usted, primo, por más que se pueda morir diez veces nunca va a terminar de entenderlo, le voy a explicar qué quiere decir aquello que medio cantaba el general mientras ellos bajaban la cabeza para recibir el agua, para oír en su lengua que el karaiva los renacía con que yo te bautizo para arrancarte tu bautismo" (150). Porque no supo leer la

preguntándole: ¿Qué he dicho Miguel? Y cuando el secretario iba a elevar la voz, el general lo interrumpía: No, sobrino, quiero que me lo digas, no que lo leas. Eres mi mano, pero toda mano debe incluir un cerebro" (129). 
pertenencia de Artigas a los indios, es que Barreiro quiso pactar con los porteños. Y esta relación con los indios es una de las principales lecturas que la novela hace de Artigas. ${ }^{159}$

Si la escritura parece jugar su lugar entre la marca que fija y la borradura, mancha que disuelve lo escrito, diseña, entonces, un lugar imposible, contradictorio, por el que pelean Artigas y Ariel. Por eso la escritura que se quiere inapropiable, se desmiente a sí misma. De allí que la gran escena de la escritura sea su fracaso, su derrota mientras su utopía es el arte de borrar. La derrota artiguista se inscribe como mancha del elegido en su cuerpo ("la mancha delataba mi derrota de entonces", 57) para volverse vacío, borradura y principio de la escritura ("Esa fue nuestra victoria", 58).

Cuando Ariel se decide a iniciar su novela sobre el héroe, un apagón en Nueva York le borra su primera página, lo convierte en otro derrotado: "Susana era infatigable para estimular al derrotado" (60). Así como Barreiro estropea las letras de sus cartas con las manchas de tinta, Pedro no logra definir los trazos de su himno a Artigas cuando la vela se consume y en su torpeza desparrama la tinta sobre la hoja. ${ }^{160}$ Hasta Peñarol se suma a la derrota sin lograr una marca.

Se trata del poder corrosivo del más generalizado virus de la lengua ("Language is a virus", 121). La utopía artiguista de la letra requiere la sabiduría del arte de borrar: "Nos ha sido dado, finalmente, el arte de tachar de una vez, con un solo golpe de pluma (...) Borrar, Ansina,

159 En 1994 Carlos Maggi publica Artigas y su hijo el caciquillo donde describe los lazos del héroes con las tribus charrúas, inaugurando una óptica que lo acercaba a los indígenas.

160 Finalmente Pedro va a optar por otro modo de escritura a través del accionar de Leyenda Negra, luego de reconocer las dificultades que lo acosaban: "Yo quería escribirle algo así como un himno servicial y poco galvanizado, pero no me salía y era mejor -todos estuvieron de acuerdo- ayudarlo a andar por ahí, menos aherrojado en bronce y en cemento" (132). 
pero con arte" (66). Artigas procura borrarse a sí mismo como principio, como nombre, como identidad para poder renacer continuamente. Rehuye el festejo de su natalicio -ni nacimiento ni muerte- sino el renacimiento continuo sin principio que lo anteceda y sostenga; "ni gallina es ni verbo" en el juego de Brahma, sin territorio propio en el vagabundeo del significante, ${ }^{161}$ negando el libro de la Constitución escrito "en lengua de nitidez" (100). Pero reconoce en el arte de borrar el lugar imposible de la utopía y es en la tensión con el surco de la letra, es en la pelea que sostiene con Ariel y su intento de fijarlo en una novela donde se dirime la posibilidad de esta misma utopía: “cómo se esfuerza ese hombre, en este preciso momento tuyo, en retenerme y en desoírme, ahora mismo, aprieta, puedo sentirlo, una tecla detrás de otra, tratando de apresar en una letra, pretendiendo trasvasar a una pantalla de las que me enseñaste, este murmullo que no entiendes; alguien se arriesga a fijar lo que no se puede fijar en un grafo, me escucha mal para existir un poco más, él lo ignora, pero se opone a un arte sublime y difícil, que me sería ventajoso ejercer, pero sabe Ansina, que muchas veces mis fuerzas, tan poderosas, menguan, tanto son necesarios aquellos como tú, aquellos que me quieren creer, como aquellos otros leales que me quieren resistir (...) ese hombre puede desoirme y asi ser mi mensajero" (101, las cursivas son mías)

Si todo es escritura, la letra apropiada por el monumento y la tinta que fluye auspician órdenes contrapuestos, diseñan diversas cartografías

161 Confrontar las siguientes citas donde se expone la resistencia a cualquier principio fundante: "deberías saber que nunca hemos tenido cumpleaños, si yo jamás he nacido, porque siempre he estado en otra parte" (99); "ocho dioses primordiales han sido necesarios para preparar el huevo egipcio del que saldría el dios solar; antes del huevo de Brahma había una flor de loto, que del ombligo de Brahma crecía, para sostenerlo tal vez, pero para que salieran luego, redondos, completos, Civa, Vishnu y también Brahma, que luego diría que todo eso, incluso a sí mismo, hijo del huevo, lo había creado él jugando. Entiende que siempre ha habido un huevo detrás del huevo, que ni gallina es ni verbo, que ha habido un Artigas detrás de mi" (100); "No puedes ver, realmente, que es este paraje por el que discurrimos el lindero en donde, precisamente, no estamos (No sabes ,todavía, no estar, apenas eres nómade) No hay mañana ni ayer" (100); "No ha sido, acaso, siempre mi arte, mayor que el de la guerra, el no estar más allá de los que quieren apresarme" (101). 
de lo "real", de la historia, de la temporalidad, deciden dos políticas en pugna de la lengua.

El cristianismo fue el inicio de una política de la letra que apresaba lo "real" en una temporalidad contable a partir del año cero, que instituía un "mundo uniformado en tiempo y letra (...) atrapado por la norma de las simetrías" (32) y que, bajo los imperativos de la conquista y evangelización, desembarcó en América “convirtiendo al mundo en una esfera abarcable, el primer gran paso para surcarlo en naves, apresarlo con infernal papeleo de mapas y relaciones, para historizarlo todo, redondo y dócil como la manzana de la sabiduría" (32). Sabemos, la letra que escande la temporalidad en un orden fijado y según un principio trascendente, es, necesariamente, una lengua de la conquista y el sojuzguamiento, es la letra de la corona, del rey, del Padre.

Artigas recupera otra matriz, aquella diseñada por Ovidio en sus Metamorfosis, que des-arma la política del Principio en el caos y licua la temporalidad progresiva en el devenir constante de las metamorfosis y mutaciones: "Los franciscanos me hacían traducir las Metamorfosis, libro que tal vez hayas tenido oportunidad de conocer, y que fue para mí una de las primeras claves que me llenarían la sangre. Sí, fiel escudero, Ovidio comenzaba su historia a partir del caos, y a partir del caos y de cientos de transmigraciones" (32). Artigas se levanta con la señal del elegido, del Anticristo, del lobo Fenris para descolocarse a sí mismo como principio fundante de la nacionalidad oriental, como héroe patrio y recolocarse en las huellas de la metamorfosis, del flujo inapropiable por las políticas de las coronas “¿porqué, en aquellas horas, fui yo uno de los pocos, casi el único, que repelió todo intento de poner en estas tierras una corona, de inca, de borbón o de quien fuera?" (31). Es en esta trama donde cobra otra dimensión el impulso libertador de la gesta artiguista, el valor subversivo de la letra, que se desentiende de la defensa más o menos ideológica para volverse escritura revolucionaria. La política de la 
escritura se juega en la escritura y se enajena en la escritura política. Pero para suscitar esta otra lectura es indispensable -Artigas se lo recomienda a Ansina- leer del "revés" (31).

Ambos órdenes de la lengua obedecen a diferentes linajes culturales, el occidental y el latinoamericano, y permiten indagar la condición de este último a partir de sus marcas específicas: las sucesivas metamorfosis de las revueltas libertarias desde Tupac Amaru a Artigas y la significación de la derrota junto a la sangre derramada como vehículos para inscribir en la página "la voz infiel del indio", su sed aún no saciada. La estrategia del éxodo le sirvió a Artigas para crear el vacío, la página en blanco donde roturar el relato de la derrota con la sangre de su tropa, para marcar los surcos de la historia propia e inapropiable, incomprensible para el conquistador:

"No les dejamos ni pampa blanca ni semillas de ningún color, porque no les dejamos casi gauchos, y casi ningún indio a los portugueses, cuando llegaron, para que no pudieran marcar sobre sus pechos rasgados la señal del vasallaje y del imperio. Ni papel ni tinta; se precisan hombres para que haya tinta o papel. Sólo se encontraron con un suelo abierto y borrado, como el de los primeros días, regado aquí y allá con sangre definitivamente infiel, reseca, indescifrable, y a la larga, con esa paciente hecatombe, terminamos venciendo en el papel intratable de esta tierra (...) Esa fue nuestra victoria, Ansina fiel. Hicimos un país vacío, una tierra deshecha y lúgubre que guardó la voz infiel del indio en la sangre que le bebimos, una tierra inexpugnable, por un buen tiempo, a la avidez de la historia (...) podemos, una vez más, salvarnos y perdernos en el tiempo perdido de los indios alucinados de Tupac Amaru, el de calaveras ansiosas que esperan un milenio para retornar, o podemos, por el contrario, incrustarnos en el devenir fatídico y culpable a que nos condena la cruz" (58) 
Ese vacío inicial del éxodo está lleno, sin embargo, de textualidades, de citas. En ese éxodo el archivo se convierte en hipertexto y Artigas Blues Band ofrece sus ventanas cuyos vínculos se anudan en la escritura del lector a través de los epígrafes, relatos que siguen la trama, documentos oficiales, mitologías, teatro, música, literatura dentro de la literatura, escritura dentro de la escritura. Es que el principio es una letra, la primera letra, la A y su capacidad diseminativa que expande el (A)rte: Artigas, Aguirre, Ansina, Artola, Artie, Ariel, Adela, Ana, América, Amir (H)Amed..., porque la A es alfa y es el Aleph, me refiero al borgeano, "un Aleph es uno de los puntos del espacio que contiene todos los puntos (...) el lugar donde están, sin confundirse, todos los lugares del orbe, vistos desde todos los ángulos”. Artigas, según parece, lo leyó: “Antes de partir había que hacer una seña, y dejaron marcada en una pared una enorme letra A, sí, Ansina, si este es el Alfa, el Aleph, dejemos que se preparen para Omega, el mundo ha sido cernido para saciar nuestra sed" (14).

La estabilidad del significado capaz de dar identidad se cuestiona también en el orden paradigmático como una sustitución del nombre propio, así, por ejemplo, Gustavo que recibe desde el comienzo los apodos de Vishnu y Moe, ingresa en una acelerada carrera que desorbita su identidad en múltiples nombres. La estructura de la novela instaura el recorrido del revés al comenzar por el diabólico capítulo 6 descontando hasta el 1 que es, a su vez, punto de arranque del 11, su reiteración al infinito, el principio de las metamorfosis. Las mutaciones parecen debilitar los límites de las palabras que pierden su integridad en un devenir constante del juego: María Pía/Ana/Mariana; Camel/camello; Castor/Coster....

La textualidad de Artigas Blues Band es un continuum de la escritura que fluye y en su fluencia mezcla las voces narradoras de sus personajes, transita por la contigüidad de los espacios, se desplaza cómodamente por los tiempos diversos, abre pasajes entre la vigilia, el 
sueño, la literatura, desarma las matrices genéricas. Y es el humor el que muchas veces diluye las fronteras entre diversos tonos del discurso, relee la tragedia en clave cómica, la épica como chifladura.

La escritura como escape al sentido definitivo, como huida a la inmovilidad del significado y a la plenitud fundada y fundante, es el combate que Pedro libra con la creación de una organización subversiva, Leyenda Negra. En principio se trata de explorar el fundamento de la palabra, su trascendencia, "la eterna cruz de madera (que) sostiene la tierra" y nadie mejor que él que ha nacido como Pedro -"tu nombre es piedra y sobre ella construirás mi iglesia" (90)- para invertir su propia identidad, para pulverizarse. Pedro emprende un recorrido por las creencias, religiones e idolatrías de los uruguayos, los testigos de Jehová, las ofrendas de los Hari Krishna, la promesa "rigurosamente evangelista" de una empresa para cambiar la vida de sus adeptos, la no menos fanática idolatría por Artigas. Incrédulo frente a tanta creencia, leyendo la vacancia detrás de la fe, prefiere el juego gratuito del casino y allí gana el dinero con el que enfrentará la incapacidad de sus congéneres para "no esperar realmente nada" (89). Sustituye, entonces, la trascendencia del significado por el juego intrascendente del significante, sustituye a Cristo por Brahma.

Se decide a refundar en la tradición de los Tres Chiflados y de Brahma, en la irresponsabilidad del juego "qué era lo que pretendían que él fuese a fundar. Si él solo había sabido enrolarse una congregación de mismos, the three stooges o la trimurti (...) claro, tres esbirros irresponsables y casi adolescentes, él Larry, y también cuando fue Brahma lo más atractivo era la irresponsabilidad de que él había hecho todo eso, el mundo, jugando, vaya cosa" (102). Una de las primeras acciones del grupo subversivo consiste en -al mejor estilo de los tres chiflados que apuntan sus brazos hacia tres direcciones diferentescambiar el sentido de las calles y confundir sus nombres. No se trata de 
una célula terrorista sostenida en un ideario político. Se separa de la guerrilla de izquierda de las décadas anteriores proponiendo no ese proyecto político, sino una vasta confusión, una subversión más raigal, la del significado como totalidad. Leyenda Negra se ocupa, en nombre de Artigas, de pintar con graffitis las paredes de Montevideo y pintarrajear los rostros marmóreos del prócer, travestirlos. Es la horda salvaje, bárbara, que irrumpe el espacio estriado de la ciudad para volverlo liso, es la banda de Artigas (Artigas Blues Band) que desterritorializa los iconos fundantes de la patria para retroescribir el pasado.

Si una de las estrategias de la escritura en el poder es contener su fuerza en la petrificación del monumento, otra de ellas será lo que la frase coloquial certeramente define como "tapar la realidad", encubrirla. La carpa con que el gobierno enfunda el increíble suceso del despertar quijotesco de Artigas cumple acabadamente esa función. También Artola se dedica a recubrir los vacíos convirtiendo al lenguaje en una prótesis, que procura ocultar su propia condición: detrás de la prótesis se encuentra el vacío del significado trascendental, la vacancia del Padre y es por eso mismo que también oculta su impericia de padre fracasado por el abandono de su hija, su incapacidad para escribir en su hija el nombre de lo sagrado -la prótesis- "María Pía" (los otros, Ariel, Gustavo, Pedro, parecen no tener padre, y el padre de Susana se llama, curiosamente, Artigas).

La propia condición de Artola radica en "pasar oculto" (117), en tramar la ofensiva desde el sótano de una oficina, en instaurar la prótesis de Artigas: "esta misma mañana, lo había descubierto: faltaba, en medio del ajetreo bursátil y de los cheques por cobrar, el busto de Artigas. En el rostro tenso del primer empleado que lo atendió, asegurándole que lo iban a reponer, señor Artola, podía adivinar su propio rostro desencajado. Logró, gesticulando profusamente, que, mientras tanto, pusieran algo en su lugar: una especie de mampara, una oscura prótesis contra el vacío; 
detrás del implemento, puede sospecharse, se esconde el busto" (144). Entonces Artola opera, sin quizás advertirlo, la inversión de su propio accionar: al cubrir el vacío, lo revela. Emplea la misma lógica con su hija Adela, recorta en las fotos familiares su rostro, le niega entidad para reclinarse en el sosiego de lo familiar, pero el corte revela que ella falta y revela su falta, su falla provocando inestabilidad: "En el cajón del escritorio estaban las fotos de la familia, que había logrado enmendar, en el peor de los casos, recortando, y en las que, amén la inestable composición del cuadro, no se sospecharía a simple vista que alguien falta. Si se nota inestabilidad, es mejor hacer inmediatamente algo, como trabajar, como encender la radio" (144). Artola se ve atrapado en el mismo sistema -el de la escritura- que quiere desconocer, su nombre lo atestigua como una de las variantes en el juego expansivo del Arte, Ariel..., e igualmente Artigas porque también se llama José, José Artola.

Artola se enfrentará con el grupo subversivo Leyenda Negra, su peor enemigo, el nihilismo, peleará con su doble invertido, lo reconoce inmediatamente porque lo conoce, es parte de su identidad "porque su vida había sido dedicada (...) a la superación espiritual" (143), es el otro. Artola no teme a las diversas sectas religiosas que se corren de la norma cristiana porque forman columna con lo mismo, "pero estos otros, estos nihilistas desaforados, sí son un peligro. Nada predican, nada esperan, y atacan violentamente la tradición" (144).

Luego de trocar los nombres de las calles y pintarrajear paredes y bustos, Leyenda Negra asume hasta sus últimas consecuencias la rebeldía satánica, la violenta trasgresión de las normas para llevar lo conocido a la conflagración final, a la subversión total que espera el fin del milenio, el fin de los tiempos y dar nacimiento así a la bestia que Pedro incuba en el vientre de Ana, para que, definitivamente lo monstruoso advenga como una letra indómita, la letra del vampiro. En esta tónica, Leyenda Negra profundiza sus estrategias. Desde la "leyenda negra", Artigas deviene 
monstruo, "ogro", vampiro, la alteridad irreductible -sin principio ni fin, sin genealogía- que demanda toda retroescritura.

Pedro se deja atrapar por su enemigo Artola invirtiendo los roles, confundiendo al perseguidor con el perseguido y es que de eso se trata: de confundir, de desarmar las antinomias, los binarismos, de leer en el signo lo que éste rechaza, su otro oculto o expulsado del sí mismo. Y este es el modo en que Pedro escribe, en que Pedro lee: traslada el significado a su contrario instaurando la más absoluta ambigüedad, aquella que no se puede dividir, dirimir, desambiguar. Su estrategia para resultar atrapado por las fuerzas de Artola consiste en escribir un graffiti que copia frases latinas: "Quo usque tandem Catilina" y "Cave canem" y que merecen la erudita interpretación de Artola:

“(B)ástele saber que Catilina era también miembro del senado y que había estado confabulando un magnicidio, que fracasó, y de cuyo fracaso el mismo Cicerón no fue ajeno. Esas cosas se hacían por la noche. A la mañana siguiente, Cicerón no imaginó que a Catilina le diera el rostro, como se dice, para aparecerse, tan campante, por el senado, y ni bien lo vio, improvisó un magnífico discurso que comenzaba diciendo -se lo digo en castellano: Hasta cuándo, Catilina, abusarás de nuestra paciencia. Se da cuenta de que lo que este hombre escribió, citando al gran escritor latino, puede ser leído como una defensa de Artigas, en vez del vilipendio usual que tenemos que leer. Cuidado con el perro, Cave canem, era un graffiti, es decir una inscripción, en un muro de Pompeya (...) Por lo visto este hombre es un humorista" (196).

Pedro escribe este graffiti debajo de otros, blasfematorios, dirigidos a Artigas y es en este cotexto que la cita adquiere un significado que él mismo explica a Artola como una defensa contra quienes quieren traicionar y cometer un magnicidio con el héroe patrio. Asume el lugar de Cicerón y atribuye al perro el valor de la fidelidad. Pero, sospechamos, 
Pedro no cita para duplicar, para copiar, sino para contrabandear un sentido otro que la ambigüedad de la lengua autoriza: el que trama el magnicidio -Catilina- sería Pedro que intenta liquidar la imagen de Artigas como Padre, padre de la patria y de la univocidad del signo, y en este sentido es efectivamente fiel como el canem a Artigas, no a la imagen paterna sino a su potencial devastador Pero también el cave canem - cuidado con el perro- es una advertencia y es una pista que lo liga a ese poder corrosivo asumido por Leyenda Negra (recordemos a "los perros cimarrones" que aludían a las tropas de Artigas). En estas idas y venidas por sentidos opuestos que se incluyen a sí mismos desbaratando sus límites se explora la ambigüedad raigal del signo.

Esta estrategia aquí analizada a partir de una cita que Pedro cita pero no copia, puede extenderse a la entera novela, donde cada significación parece incluir su contrario. Nombremos algunos casos: el fín del mundo como principio del mundo; la catábasis y la anábasis: el descenso al infierno de Lope de Aguirre y el ascenso volátil de Ariel -genio del aire- convertido en vampiro; la figura de Artigas como aquel que funda destruyendo; e incluso esta ambigüedad opera constantemente en las citas que la novela hace en sus epígrafes, como por ejemplo aquellos fragmentos en el cual un historiador critica la figura "bárbara" de Artigas y que sin embargo la novela recupera invirtiendo el sentido.

Se trata de concitar "relaciones peligrosas" entre los términos, entre las citas, entre los textos, entre los personajes, entre los valores, tarea predilecta del vampiro, de Satán que todo lo confunde. Si la escritura se ofrece ante el vacío como inevitable citación de otros textos, entonces el vampiro se convierte en la imagen del escritor latinoamericano que succiona del entero archivo de textos no para copiarlos sino para regenerarlos o degenerarlos, para estropearlos en el teatro que Pedro edifica a la medida de un infierno dantesco en cocoliche y digitado por la sabiduría milenaria de su portero, Klaus 
Kinski-Nosferatu-Lope de Aguirre. Allí, arriba Artigas acompañado de su fiel escudero para, en una experiencia de anagnórisis, reconocerse en la estirpe infernal del quiróptero americano.

Como una puesta en abismo -con ribetes grotescos- se nos muestran los poderes barroquizantes del vampiro americano, acostumbrado a beber, insaciable, de la vasta literatura y a confundir sus textualidades, géneros, lenguas y tonos. En la segunda escena de la sátira de Pedro, se acerca Choderlos de Laclos a pedir explicaciones al portero infernal pues su refinada literatura -"mes liaisons dangereuses"- se vio entorpecida por el injerto de un texto ajeno, más precisamente de la autoría del mismo portero de múltiples nombres, quien se niega a enmendar tamaño barullo: "Pas possible. Siempre ha habido y habrá mucho azar" (170). Y es que entre los poderes que pertenecen al vampiro no sólo está la sed insaciable, sino también la "infección", ${ }_{162}^{1 a}$ la peste que contamina la literatura, y en especial, la latinoamericana. ${ }^{163}$ La rebeldía de Satán -y su serie de acólitos- es la que guiará la insurrección de los signos contra lo legible, afán que esta novela persigue y cuya condensación puede leerse en la abigarrada mixtura de la sátira demoníaca de Pedro. ${ }^{64}$ En términos de Pedro "la más frugal de las

162 En las siguientes citas se menciona el poder contaminante de la escritura: "Nosotros hablamos todas las lenguas; somos, precisamente, el principio de la infección, los hidrofóbicos de todas las eras, los dioses del contagio. Teníamos todas las formas, y los pueblos no solo nos temían, también nos veneraban" (161).

163 Confrontar con: “Ay, los vampiros de América, los inocentes ratoncitos de América, los que ahora soy yo. El Gran Vampiro que se alimenta de la sangre de todos los cristos, de todos los indios que no están, de los curas que maté, del dulce plasma de mi niña Elvira" (161).

164 La rebelión aparece compartida por Lope de Aguirre y Artigas: "Yo, Lope de Aguirre, rebelde toda mi vida, y, como tú y te guste o no, toda mi muerte. Contra el dios soso que quiere dejarnos sin milenios, que nos quiere terminar esta furibunda muerte. No me mires así, Artigas. Tienes mala memoria. Recuérdate, ibas a pelear con perros muertos e hidrofóbicos. Te fuiste al Paraguay, para armar otro ejército de sedientos bárbaros, de dulces vrykolakas, a arrasar la tierra traicionada, pero no pudiste (...) Había explotado el mundo cuando fuiste Artigas, y te fuiste asordinando en el exilio (...)" (162). La rebeldía inicial de Artigas, es lo que según Pedro, éste 
novelas" debe asumir "el demonio" ya que, "repito, no se escriben novelas sobre el padre" (154).

Los ataques subversivos de Leyenda Negra se vuelven, cada vez, más osados. Nilo y Roberto-Des Esseintes matan a Leda, la esposa de Gustavo y se convierten en criminales. El escritor y su banda como homicidas del "cuerpo de la letra", ${ }_{165}$ como "asesinos desinteresados" (184), inauguran el derrame de sangre y tinta ya ilegible del vampiro. ${ }^{166}$

Ariel, quien procura escribir la novela sobre Artigas, adviene un vampiro como término final de las metamorfosis de la figura del escritor, animal voraz y desorbitado que desparrama su tinta volátil: “(Qué avidez, deglutidor, más devoras y es más tu hambre de vampiro galáctico, más tus babas serviciales caen a pico desde tu noche estrecha, para untar el ovillo de lana del mundo con tu tinta digestiva. Radiante y negro todo lo mareas con el viento de tus giros enloquecedores. Radiante, negro y babeante, todo lo cuajas, todo lo centrifugas con tus alas abismales y negras. Como un eco remoto, desde allá abajo, puedes oír tu canto)" (275).

Gustavo, acatando órdenes de Pedro, emprende una suerte de peregrinaje religioso por aquellas sedes de monstruos -las iglesias góticas, la ciudad gótica de Barcelona, el museo de cera, el golem de Praga- para arribar al punto de origen y sostén último, el desierto (que

debe retomar en el presente para escapar a su estampa escolar.

165 En "Aprendices y criminales", Amir Hamed habla sobre el escritor como asesino "De todos modos, ese asesino virtual, homicida del cuerpo de la letra", en página web.

166 Los nombres parecen relacionarse con esta nueva actividad de Leyenda Negra. Nilo remite tanto a la fluidez del río, la fluidez de la sangre derramada, como al río egipcio, en el cual -recuerda Gustavo- "de su limo se hacían los primeros papiros", aludiendo al principio de la escritura entendida como tráfico ("Tendría que recordar que los egipcios hacían barcos de papiro", 284). Des Esseintes apuntaría al carácter desinteresado de este arte criminal, falto de todo interés por sustentar un proyecto ideológico, recuperando así cierto matiz propio del decadentismo. 
también alude al desierto uruguayo-oriental) como el espacio natural de la horda salvaje. Pero allí también advino la letra como Ley del Padre divino: "En un lugar como este que rodea la ciudad, en un lugar de este interminable desierto que baña de arena las cúpulas y los techos en las tardes, se le apareció a Moisés un dios atronador y alfabetizado, que le entregó unas tablas para que hiciera planas (el pueblo ágrafo adoraba una res dorada)" (238). Desde luego que la intención de Gustavo es subversiva, destruir la letra en tanto Ley. Su tendencia de piromaníaco lo lleva a quemar el busto de cera de Artigas en el museo de Madrid. Poco antes de llegar a su destino final mata al camello que lo había conducido (recordemos que el camello, al contrario del buey, es un animal nómade) y recibe el último mensaje de Pedro, cifrado en el billete de dólar, poco después de que Mariana le ha robado su tarjeta de crédito: "Te diré que, a pesar de lo parco y verde, tu último mensaje ha sido bastante barroco. Un billete de dólar hoy es una reliquia, no hay dudas y eso lo puedo entender (...) En el borde de abajo, el archisabido In God we trust. Me dejaste una reliquia devota y te llevaste mi perdurabilidad crediticia, te quedaste con mi eternidad de pecador de la Gold Card. Además, en el billete está todo: el ojo de la esfinge y la pirámide. Claro, si siguiera hacia oriente, como yendo hacia Aggartha o Jerusalem (...) me encontraría con las pirámides, y con el Nilo, y tendría que recordar que de su limo se hacían los primeros papiros. Tendría que recordar que los egipcios hacían barcos de papiro y cosas por el estilo: Tendría que hacerle dos o tres preguntas a la esfinge, etc, etc. Tal vez así empezara todo de nuevo ¿verdad?” (284).

Entonces, Gustavo se queda a la intemperie sin su tarjeta Gold Card, sin crédito, sin creencias y con el dólar que hace de la fe una reliquia de museo, esperando el fin del mundo para el renacimiento de otro ("un Fiat nuevo" que se sortea en la pantalla del televisor) cuya 
escritura invertirá la hoja, ecribirá -como Gustavo- en el revés de los textos: "Buenas Noticias". ${ }^{167}$

El contraste de esta novela con el resto del corpus aquí analizado es notable. Parece enfrentarse a la tradición del género, desarmarla, dotarla de un nuevo sentido o abrirle una línea de fuga.

Artigas Blues Band dialoga con la "movida de los ochenta", caracterizada por el despertar de una serie de manifestaciones culturales que abarcaron un renovado movimiento rockero, la escritura de graffitis en las paredes de Montevideo, performing artists, revistas subterráneas, los lumpen poetas a cargo de jóvenes veinteañeros. ${ }^{168}$ Sus propulsores fueron Pepi Goncalvez, autora de graffitis, Lalo Barrubia, seudónimo de la poeta Rosario González, Rubén Tani, impulsor de varios eventos y Rafael Bayce, impulsor de la movida anti-razzias.

Son los herederos del fracaso de los ideales sesentistas de sus padres y contra esa herencia político-ideológica se levantan para declararse huérfanos y apostar a una renovación cultural desde propuestas más estéticas que ideológicas: "La lucha armada fue un fracaso, el socialismo real un fracaso, el modelo tradicional un fracaso: no había ningún modelo atractivo". Se enfrentan en los inicios de la democracia a aquellos que aún soñaban con algun revival, para proyectar algo inédito. Dice Rafael Bayce: "Son los que yo llamo los neodionisíacos, en el sentido de que liberaron las pulsiones sin ningún control apolíneo. No

167 El "revés", el reverso, es una palabra reiterada en diversas ocasiones en la novela, ya hemos citado algunas de sus apariciones y ahora recuperamos otras. Artigas se pone de pie para propinar una "cachetada justiciera", "un épico revés" (10) al macró que se niega a pagar a la prostituta, que se niega a mercadear con la pornografía de los textos (el mercader: otro de los términos que se vinculan con el tráfico de la lengua, perceptible en el billete final que Gustavo recibe y que lo asocia a la figura de Hermes como traficante). En otra oportunidad, Gustavo, como una puesta en abismo de su proyecto literario que culmina en la composición de la entera novela, le escribe a Pedro una nota con las palabras invertidas, al revés.

168 Citas tomadas de "Movida cultural de los ochenta", en página web. 
eran ni nativistas, ni retrospectivistas ni revivalistas. Estaban queriendo emerger $\sin$ antecedentes, sin raíces fuertes y sin hacerle caso a las narrativas heroicas y épicas".

Perciben la restauración democrática como "una ética obsoleta, la cultura volvía a ser la de los sesenta"; sin embargo ellos se reconocen creando una cultura "profundamente nacional". Se alejaban de la militancia política anclada en los partidos: "Habíamos visto militantes fracasar alrededor y teníamos como un raye no militante", pero tampoco reconocían estética alguna: "Sobre todo porque no había tampoco ninguna estética atractiva y eso era lo que más pesaba". Fueron percibidos como "una díscola turbamulta que estaba poniendo en peligro los sólidos cimientos de la cultura uruguaya". Resulta evidente que la banda de Artigas Blues Band los refiere y hace de ellos la horda de Leyenda Negra.

Si las novelas anteriores partían de un acontecimiento histórico y desde allí articulaban una serie de críticas a las estrategias hegemónicas de construcción de la memoria, a las políticas del olvido, a las prácticas autoritarias de la palabra y la escritura; la novela de Hamed invierte el recorrido. Ataca la raíz de la escritura para luego apuntar a los monumentos (el Mausoleo de Artigas como ícono máximo de la dictadura), las versiones historiográficas sobre Artigas, la parafernalia de homenajes y festejos patrios, todas escrituras sedentarias del estado. Desde el foco provisto por la "leyenda negra", desde el "éxodo" histórico y desde su final "derrota", Artigas puede convertirse en arma demoledora de todo intento por adocenar la cultura.

Un deseo de restitución de las historias de los márgenes recorría las novelas del primer grupo. Artigas Blues Band carece de este gesto, atacando cualquier tipo de historia que arribe a una cristalización y cierre los sentidos. Regresa a la historia pero no para discutir algún perfil del 
héroe, ni atacar versiones, exaltar facetas, sino para hacer de Artigas una máquina de escritura nómada. Lo cual significa un proceso de relectura -de retroescritura- que diluye la distancia entre pasado y presente. Si la lectura del pasado se hace inevitablemente desde el presente, entonces la novela exasperar esta lógica resucitando a Artigas.

La matriz estética de esta novela dista del realismo de las anteriores, se lo podría colocar en la línea de ciertos atípicos de la literatura uruguaya (Felisberto Hernández, Armonía Somers) con rasgos de una prosa barroquizante, para desde allí desarticular el formato de la novela histórica. Su estructura rizomática, la frotación de textos de diversa índole (desde los documentos históricos hasta letras de rock candombe de Rada, fragmentos de poesías, chistes de los tres chiflados, citas en latín, etc.), la presencia nómade de diversos narradores, los anacronismos, el pastiche, el grotesco, el humor (mucho más el humor absurdo de los Tres chiflados que una sátira con moraleja), el disparate, desbordan los límites del género o lo reconducen por otras vías. 


\section{HISTORIA Y FICCIÓN}

A partir del análisis particular de cada novela es posible colocar a Artigas Blues Band como una propuesta alternativa -cuando no reactivaal resto y, en alguna medida, a la tradición del subgénero, evidenciando una voluntad de refundarlo. En cambio sorprende la coincidencia en propuestas, estrategias y estéticas en el primer grupo cuyas características abordaremos ahora para marcar las diferencias introducidas por la novela de Hamed.

La novela histórica de la posdictadura instaura una fuerte relación entre historia y ficción a partir del documento como garantía de verdad. "Documento" y "verdad" adquieren en este espacio un sentido preciso y delimitado. La apertura de los archivos exhuma los "documentos de la barbarie" que la historiografía hegemónica arrojó fuera. Ésa es la escena primaria que organizan estas novelas (más allá incluso de que las versiones oficiales hayan efectivamente expulsado o no estos documentos). Es más, se constituyen en documentos en tanto fueron expulsados, en tanto significan ese "Otro" que, como señalan Foucault y De Certeau, la disciplina ignoró por largo tiempo. ${ }^{169} \mathrm{El}$ "Otro" se autoriza en tanto víctima de un régimen dictatorial pero se expande para abarcar diferentes sistemas de dominación o sometimiento (etnocidio, esclavitud, guerra) e irrumpe en la continuidad de la historia con un "acontecimiento" que quiebra los relatos fundacionales del origen y del progreso. Si la historia oficial ha trabajado el monumento para convertirlo en documento y así naturalizarlo, la posdictadura cuenta ya con el proceso inverso que hace del documento de barbarie un monumento como lo es Nunca Más. Quizás sea posible ver en este

169 Cfr.: Michel de Certeau, La escritura de la historia, op. cit., y Michel Foucault, La arqueología del saber, op. cit. 
corpus un equivalente de lo que la publicación de Nunca Más y la exhibición del juicio a los militares significó para la Argentina.

El documento de barbarie, entonces, como garante de "verdad", pero no de la verdad sino de una verdad. Al tiempo que estas novelas instauran la verdad, la discuten en su integridad y validez. Se escenifican sus espacios -museo, libros de historia, archivos, epistolarios, recortes periodísticos, partes de campaña, monumentos- como territorios de lucha donde se juegan, además y sobre todo, diferencias éticas en una perspectiva que evita el gesto de arrogarse una verdad asertiva y unívoca. Como vimos, el cruce de versiones opuestas procura sostener un esquema dialógico para que, en definitiva, la verdad surja como efecto de lectura, como elección del lector y no se imponga desde el narrador. El lector es interpelado como sujeto libre y responsable de sus posicionamientos éticos (más que políticos, o lo político desde lo ético), ya que la ética se constituye en eje ordenador de estas novelas. La autoridad se corre hasta su punto extremo, no le pertenece desde luego al estado, pero tampoco del todo a los documentos, y el narrador prefiere entregarla al lector.

El prólogo formaliza el nuevo contrato de lectura y sus reglas. Cita el documento como aval de la verdad histórica pero también de la verosimilitud ficcional y asimismo como principio desde al cual se negocian los límites de la ficción. Por un lado se evita todo procedimiento que parezca atentar contra el verosímil realista, por el otro se advierte al lector, en más de una ocasión, sobre el carácter ficcional de alguna escena como si la distancia con el documento engendrara culpa o temor. $\mathrm{Y}$ en todo momento se insiste sobre el respeto a la verdad histórica. El editor MMR advierte en el prólogo de ¡Bernabé, Bernabé! sobre cada uno de los núcleos ficcionales:

"Pese a este perceptible respeto por la verdad histórica, juzgo conveniente subrayar que, a mi juicio, sus afanes fueron bastante más 
allá que los de un mero cronista. Trascendiendo, para bien o para mal, la relación de los hechos y la indagación de sus causas, hay una tendencia constante a revivir los episodios como si hubieran sido percibidos, aun a costa de la introducción, a veces no confesa, de elementos ficticios: la emoción de un indiecito aturdido por los primeros festejos de la victoria de Sarandí, la imaginada apariencia del vaquero Lorenzo González y las últimas y antagónicas visiones con las que la vida acaso despidió o expulsó a Sepé y Bernabé, son tres ejemplos que valoro como pertinentes, pero no únicos" (22).

La segunda versión de ;Bernabé, Bernabé! resulta el ejemplo paradigmático de la obediencia al documento ya que el motivo que provoca su reescritura es la publicación de nuevas investigaciones sobre el exterminio charrúa. Sin esa base, sostiene De Mattos, no se "hubiera sentido en posesión de documentos, datos e interpretaciones suficientes para arriesgarse a escribir esta novela y la presente versión definitiva" (9).

Pero también en los prólogos aparecen las tensiones o conflictos entre el archivo oficial y los documentos alternativos. ¡Bernabé, Bernabé! (primera versión) sitúa la relación con el documento en una nota del autor donde "expresa su deuda con don Eduardo Acosta y Lara, cuya labor de investigación, recogida en su obra La guerra de los charrías, fue de consulta continua para la solución de muchos de los problemas que se le plantearon en esta novela". En el prólogo se adelantan las críticas a la versión oficial que Josefina lleva a cabo. Ella es a la vez garante de la verdad histórica por su "memoria prodigiosa", por discutir los vaivenes de la historia con los "prohombres" del Río de la Plata, por su nutrida biblioteca y el acceso al Archivo de su marido, pero también muestra una actitud crítica y desviante frente a estos 
documentos ("denunciar flagrantes contradicciones", "recuerdos inoportunos", "actitudes imprevisibles").

La fragata de las máscaras exhibe una complejidad mucho mayor en cuanto se trata de una reescritura de otra ficción, Benito Cereno de Melville, la cual sí tiene como fuente un acontecimiento histórico. El carácter de novela histórica es, por lo tanto, más difícil de sostener. Yo la he incluido por varias razones: remite en última instancia a un hecho "real" y Josefina escribe desde un contexto histórico atravesado por conflictos que desea comprender, como ya analizamos. Pero sobre todo y más allá de esos rasgos, es una novela histórica porque muestra una clara voluntad de instalar una lectura sobre la historia, de poner en juego un "uso público de la historia". En este sentido discrepo, en parte, con las normas que permiten considerar a una novela como histórica a partir de la distancia del escritos con el evento histórico que narra y de la inclusión de personajes históricos. Creo que el carácter de una novela histórica debe definirse -además de aquellas normas- mucho más por su interés en llevar a cabo una lectura significativa de la historia. En este sentido me pregunto, por ejemplo si El entenado de Saer en tanto reflexión sobre la condición existencial del hombre puede pensarse como una novela histórica, tal como ha sido considerada por varios críticos.

Dado el carácter particular de La fragata de las máscaras, cuyo punto de partida es la ficción, la estrategia para fundar la "verdad" corre por otros carriles, también ficcionales, que se exponen en la "Nota preliminar" de MMR. La carencia de documentos se denuncia como tal: "Con minuciosidad, he buscado en la muy nutrida biblioteca de los Narbondo algún libro sobre antropología, mitología o historia africana. No lo he podido encontrar" (15) y también se denuncia la apropiación de la voz de los personajes en términos de máscara: "no discurre en las disquisiciones de los esclavos un pensamiento auténticamente africano y sólo pulsa, en su trasfondo, la solidaria angustia que acosa a una única 
mente blanca que se esconde tras esos personajes" (15). En definitiva: se dice cuando y dónde se inventa y se miente (a pesar de ello también cita fuentes: Chacha, la criada liberta y el conocimiento de Rutilio Trajano Alves Macedo).

El príncipe de la muerte acusa la escasez y contradicciones en las fuentes como una operación del archivo oficial al tiempo que sostiene su escritura en la búsqueda incesante de documentos de la barbarie: "Un prolijo relevamiento de la hemeroteca de la Biblioteca Nacional de Montevideo, me mostró con claridad que era poco y nada lo que se conocía de Montenegro o que, en todo caso, ese conocimiento había sido ocultado durante más de un siglo" (8). El documento se legitima por haber sido arrojado del archivo oficial y es esta expulsión la que autoriza la ficción como acto reparador.

El prólogo de El archivo de Soto ya yuxtapone -como en el resto del texto- una carta de Soto con la voz de la narradora (identificada con la autora) en un pacto que adelgaza las diferencias entre historia y ficción. Allí constan los datos fehacientes sobre el archivo de Soto que aseguran su existencia, refrendada por las citas de sus cartas a lo largo de la novela y por la frase de Mansilla "Los abismos entre el mundo real y el mundo imaginado no son tan profundos" (9). Una cinta ancha de bayeta colorada carece de prólogo y desplaza la autoridad hacia la figura del periodista Salamanca y la cita de documentos históricos de variada índole (recortes de periódicos, "gacetillas", "reportes de época", párrafos de historiadores) que resultan interpelados -en tanto versión oficial- por el periodista.

Pero además los prólogos adquieren otras significaciones, señalan las reglas interpretativas del texto a través de la fuerte presencia de la voz autoral (o del editor en las novelas de De Mattos). MMR adelanta el camino interpretativo de La fragata... "Aseguro que en ella [la frase] está 
inscrita, por entero, la historia que nos aguarda", (17). Hay una voluntad expresa por guiar los sentidos de la lectura, digitando especialmente la relación del pasado con el presente en el sentido habermasiano del "uso público de la historia". El autor interpela al lector señalando un menú de posibilidades: la novela histórica como espacio de indagación de antecedentes de la última dictadura, de intentos por tramitar su sentido ominoso, de saldar simbólicamente las deudas con las víctimas del pasado o desplazar el duelo, como recuperación de las memorias de la barbarie o sucedáneo del juicio, como espejo trizado de la identidad uruguaya, como magistra vitae admonitoria.

No es sólo una pelea por las interpretaciones, algo más está en juego. Los autores disputan la condena del gobierno democrático a la revisión del pasado (acuñada por la frase "los ojos en la nuca" y sancionada con de la "Ley de Caducidad de la Pretensión Punitiva del Estado", 1986). Se trata de ver quién va a intervenir en el espacio público recientemente inaugurado, quién va a formular las preguntas y suscitar los sentidos. Esta posibilidad que inaugura la publicación de ¡Bernabé, Bernabé! con una catarata de polémicas, convierte a estas novelas históricas en prácticas intelectuales que reasumen -de otro modo- la complicidad entre literatura y política (política desde la ética, como ya dijimos) sin demasiados conflictos ni tensiones entre las dos lógicas que sostienen al género. Ficción e historia convergen -con diferente nivel de complejidad en cada caso- en un formato realista que se ha aligerado de las aristas más vanguardistas presentes en las novelas gestadas desde el realismo mágico o lo real maravilloso hasta la "nueva novela histórica" (como el uso de anacronismos, las adulteraciones de la historia, la parodia, lo carnavalesco, el grotesco, el pastiche). ${ }^{170}$ Cabe pensar en la

170 Cfr. Seymour Menton; La nueva novela histórica de la América Latina, 1979-1992, México, FCE, 1993 y Fernando Ainsa, "La reescritura de la historia en la nueva narrativa latinoamericana", en Cuadernos Americanos, año V, n. 28, julio-agosto 1991. 
necesidad de limpiar los caminos hacia la historia a través de una estética realista que no vuelva aun más oscura una "realidad" que procura explicarse y, en algunos casos, facilitar cierta tendencia didáctica.

Desde luego que la ficción no se agota en los límites estrechos que le provee el documento, sin contradecirlo va más allá. En iBernabé, Bernabé!, el editor marca como dispositivos de la ficción "el detalle" -que permite a Josefina leer los residuos descartados por la historiografíay la selección que ella opera sobre el documento para construir la trama -"Más que como una historiadora, procede como si fuera una novelista, seleccionando, entre los antecedentes de su protagonista, aquellos episodios que considera imprescindibles para delinear el carácter que afrontará las circunstancias que conforman el núcleo central de su narración" (23). El príncipe de la muerte invierte la relación historia-ficción pero lo hace para reponer un vacío en los documentos. El prólogo deja entrever el carácter fíccional de Montenegro (cita como epígrafe de Saramago, la aseveración: "Todo es ficción"), que sirve como punto de partida para indagar procesos históricos relevantes de fines del siglo XIX. En El archivo de Soto, la ficción casi no cuenta, se adosa a la historia en la común empresa de narrar ("El novelista y el historiador de vez en cuando se cruzan, se separan, se vuelven a encontrar. Tal vez estén buscando lo mismo por caminos diferentes, contar lo que importa cuando pasa el tiempo", 9), apenas sirve para introducirse en la intimidad de la familia Soto y allí leer "los entresijos" de la historia. En La fragata... la máscara ocupa el lugar vacío del documento para articular las voces subalternas.

Pero el punto que ahora me interesa es la capacidad simbólica y el armado de la trama como posibilidades abiertas por la ficción. Si ya trabajamos las redes metafóricas del texto -la figura de Cristo-Babo, las imágenes del espejo y el charco, el medallón y la locura, el cuerpo como metonimia de la violencia entre otros- ahora quiero retomar el análisis los 
"entramados" entendidos -siguiendo de un modo muy libre las propuestas de Hayden White- como un tipo particular de relato. ${ }^{171}$

Ya vimos las características de la "epopeya científica" del ciclo de novelas de Eduardo Acevedo Díaz (como un molde que articula las glorias de la independencia con la necesidad de colocar al Uruguay en las vías del progreso), cuya fractura se encuentra en las novelas de la posdictadura en tanto quiebre de un entramado épico-progresista. ¡Bernabé, Bernabé! lo sustituye con el modelo provisto por la tragedia griega que escande el relato desde el ascenso de Bernabé Rivera en las guerras de independencia hasta sus descenso al exterminio charrúa. A este estrato focalizado en el destino del coronel, la ficción suma otro entramado que diagrama la relación de Josefina con los documentos de la historia. Ella revisa el archivo de su marido y acopia las versiones sobre los charrúas, recoge todo tipo de documento oral o escrito (periodístico, partes de campaña, cartas, etc.) para confrontarlos y discutirlos, medir sus alcances. El juicio aparece como un dispositivo que ordena la búsqueda de información de Josefina, quien ocupa el lugar del fiscal encargado de la recolección de documentos, de la conversación con testigos, de la verificación de la información y las reflexiones en torno a los argumentos de la defensa y la acusación. Pero el formato del juicio se detiene en estos preliminares sin llegar a dictar sentencia.

Me interesa esta idea del "juicio" como entramado presente en casi todas las novelas para escenificar la necesidad de indagar la "verdad" a través de la búsqueda y confrontación de documentos. Una cinta ancha de bayeta colorada y El Archivo de Soto también ponen en escena los modos de abordar la historia, en el primer caso a través de la cita y confronte de documentos por parte del periodista Salamanca quien recaba información en los diálogos con el Goyo Jeta, pero también acopia partes de campaña, gacetillas periodísticas, textos historiográficos de blancos y

171 White, Hayden, Metahistoria, México, FCE, 1992. 
colorados para detenerse en los múltiples puntos de vista: "No va a haber uniformidad cuando escuche otras voces, las ajenas: no puede haberla -nunca la hubo- pero menos todavía desde la aparición de los cintillos partidarios, desde Rivera a Oribe" (15). Y en la segunda novela la narradora introduce junto al archivo de Soto, otras cartas sobre el asesinato de Beltrán que sirven para presentar el juicio que culminó con la absolución del acusado. En este caso, el acopio de documentos sirve para discutir el valor del juicio institucional y contraponerle el modelo de una justicia sin presiones políticas.

El juicio sin sentencia final, abocado a la tarea de indagar los documentos y perseguir la verdad, adquiere en casi todas las novelas características propias del policial. Este género, en el cual el crimen y el misterio que lo rodea forman parte de su legalidad, resulta el entramado ideal para capturar las modalidades del terrorismo de estado que actúa en la clandestinidad. El archivo de Soto coloca en el centro del relato el crimen de Carlos como un nudo a dilucidar, pero cuya resolución no se alcanza ("La causa de este crimen permanece aun envuelta en el más impenetrable misterio"). El relato policial canónico se desvía y no sirve para restaurar un orden sino para mostrar las políticas del secreto que rodean los crímenes del estado, tal como insiste El príncipe de la muerte, novela que también incluye sus normas. La centralidad de la justicia -otra cara de la ética- es también uno de los espacios de lo político privilegiado en estas novelas.

El contraste de estas novelas con Artigas Blues Band no puede ser mayor. En principio carece de prólogo que ajuste algún sentido, e incluso de un narrador. La saturación de documentos sobre Artigas invade el texto para socavar su garantía como sostén de la verdad y sustituirla por el juego abierto a las conexiones del lector, quien es convocado para armar con el pasado su propia retroescritura. La ficción se inicia no para perseguir el esquivo dato de algún documento marginal sino para superar 
los límites de lo real a través de la ficción. La figura de Artigas se opone, es cierto, a las apropiaciones de la dictadura (el Mausoleo), pero también a cualquier tipo de uso que lo cristalice. El éxodo y la derrota artiguistas aparecen como los lugares inapropiables por cualquier política y punto de partida -en tanto ausencia de fundamento ¿quién puede fundar sobre la derrota o el éxodo?- de la máquina de guerra contra los sedentarismos de cualquier índole. Se integra al campo de la posdictadura para señalar a la vez las dictaduras de la letra, de la escritura misma y sus posibilidades de liberación. 


\section{BIBLIOGRAFIA}

\section{Corpus Textual}

a) Corpus textual de E. Acevedo Díaz

Brenda, Montevideo, Barreiro y Ramos Editor, 1894.

Ismael, Ed. Jackson Inc., Bs. As., 1946.

Nativa, Montevideo, Biblioteca Artigas, 1964.

Grito de Gloria, Bs. As., 1954.

Lanza y Sable, Montevideo, Biblioteca Artigas, 1965.

Crónicas, Discursos y Conferencias. Páginas olvidadas, Montevideo, Biblioteca Rodó, 1935.

La Revista Uruguaya, Nos. 1 al 19, 3 de enero a 9 de mayo de 1875, Montevideo, contiene varios artículos de EAD.

b) Novelas Históricas de la posdictadura

Tomás de Mattos, ¡Bernabé, Bernabé!, Montevideo, Ediciones de la Banda Oriental, 1989.

Tomás de Mattos, ¡Bernabé, Bernabé!, Montevideo, Alfaguara, 2000.

Tomás de Mattos, La fragata de las máscaras, Montevideo, Alfaguara, 1996.

Fernando Butazzoni, El príncipe de la muerte, Montevideo, Graffiti, 1993.

Mercedes Rein, El archivo de Soto, Montevideo, Trilce, 1993.

Hugo Berbejillo, Una cinta ancha de bayeta colorada, Montevideo, Proyección, 1993.

Amir Hamed, Artigas Blues Band, Colonia, Fin de Siglo, 1994.

Amir Hamed Retroescritura, Montevideo, Fin de Siglo, 1998.

Página web correspondiente a Amir Hamed

2 Cuestiones teoricas sobre ficción, historia, temporalidad

Anderson, Benedict, Comunidades imaginadas, México, FCE, 1993. 
Baczko, Bronislaw, Los imaginarios sociales. Memorias y esperanzas colectivas, Bs. As., Nueva Visión, 1991.

De Certeau, Michel, La escritura de la historia, México, Universidad Iberoamericana, 1993.

Castoriadis, La institución imaginaria, Barcelona, Tusquets, 1983.

Gellner, E., Naciones y nacionalismos, Bs.As., Alianza, 1991.

Hobsbawm, E.J., Naciones y Nacionalismo desde 1780, Barcelona, Ed. Crítica, 1992.

Kermode, Frank, El sentido de un final. Estudios sobre la teoría de la ficción; Barcelona, Gedisa, 1983.

Koselleck, R., Futuro pasado. Para una semántica de los tiempos históricos, Bs.As., 1993, Paidós.

Le Goff, J., Pensar la historia, Bs.As., 1991.

Poétique No. 49, Le texte de l' histoire, febrero 1982, París.

Ricoeur, P., Tiempo y narración, tomo I, II y III, Madrid, Ed. Cristiandad, 1987.

Todorov, T., Nosotros y los otros, México, Siglo XXI, 1991.

Todorov, T., Las morales de la historia, Barcelona, Paidós, 1993.

Vezzetti, Hugo, "variaciones sobre la memoria social", en Punto de Vista, No.56, dic-1996.

White, Hayden, Metahistoria, México, FCE, 1992.

White, Hayden, El contenido de la forma, Bs. As., Paidós, 1992.

VVAA, dir. J. Le Goff y P. Nora, Hacer la historia, Tomos I, II y III, Barcelona, Ed.Laia, 1979.

VVAA, Usos del olvido, Ed. Nueva Visión, Bs. As., 1989.

\section{Novela histórica/ perspectivas teóricas}

\section{a) Perspectivas teóricas sobre novela histórica}

Ainsa, Fernando, "La reescritura de la historia en la nueva narrativa latinoamericana", en: Graffiti, No. 37-38, enero/febrero de 1994, Año 4.

Ainsa, Fernando, Nuevas fronteras de la narrativa uruguaya (1960-1993), Montevideo, Trilce, 1993.

Alonso, Amado, Ensayos sobre la novela histórica, Madrid, Gredos, 1984. 
Balderston, Daniel, The historical novel in Latin America, Ediciones Hispamérica, 1986.

Calabrese, Elisa, "Aspectos de la novela histórica", en: Graffiti, No. 37-38, enero-febrero 1994.

Gadea, Raúl, "El inquietante auge de nuestra novela histórica", Graffiti, No.37-38, enero-febrero, Año 4, 1994.

Garramuño, Florencia, Genealogías culturales, Rosario, Beatriz Viterbo, 1997.

Hutcheon, Linda, A poetics of posmodernism. History, Theory, Fiction, Cambridge, Routledge, 1992.

Jitrik, Noé, Historia e imaginación literaria. Las posibilidades de un género, Bs.As., Ed. Biblos, 1995.

Lukács, Georg, La novela histórica, México, Era, 1977.

Menton, Seymour, La nueva novela histórica de la América Latina, 1979-1992, México, FCE, 1993.

Rama, Angel, La novela en América Latina, Colombia, Instituto colombiano de cultura, 1982.

Pons, María C., Memorias del olvido, México, Siglo XXI, 1996.

Zanetti, Susana, "Historia y ficción de la novela hispanoamericana contemporánea", Revista de Lengua y Literatura, No. 2, diciembre, Facultad de Humanidades de la Universidad del Comahue, 1987.

VVAA, Itinerarios entre la ficción y la historia, Bs. As., Grupo Editor Latinoamericano, 1994.

b) Perspectivas teóricas generales

Deleuze, Gilles y Félix Guattari, Mil mesetas. Capitalismo y esquizofrenia, Valencia, Pre-textos, 1988.

Deleuze, Gilles, Crítica y clínica, Barcelona, Anagrama, 1996.

Derrida, Jaques, De la gramatología, México, Siglo XXI, 1998.

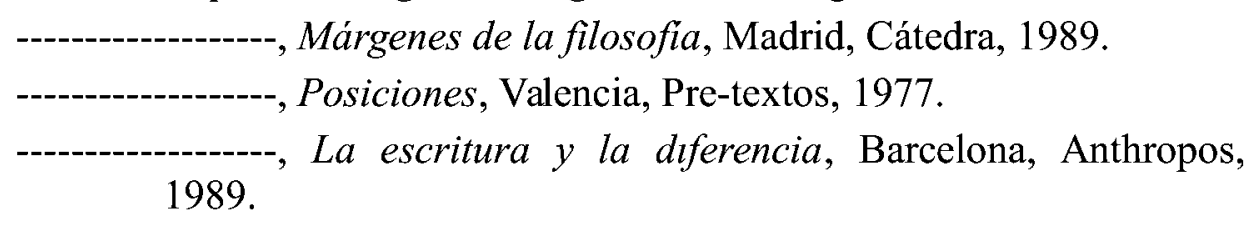

---------------, La diseminación, España, Espira1/Fundamentos, 1997. 


\section{c) Crítica sobre la obra de Acevedo Díaz}

Acevedo Díaz (hijo), E., La vida de batalla de Eduardo Acevedo Díaz, Bs.As., 1941.

Ainsa, Fernando, "De la novela de la historia a la novela histórica: la dimensión americana de Eduardo Acevedo Díaz", en: Nuevas fronteras de la narrativa uruguaya (1960-1993), Montevideo, Ed. Trilce, 1993.

Ainsa, Fernando, "Eduardo Acevedo Díaz", en: Historia de la Literatura Hispanoamericana, T. II, Madrid, Cátedra, 1987.

Ardao, Arturo, "La evolución filosófica de Eduardo Acevedo Díaz", en: Marcha, No. 628, 27 de junio de 1952.

Ardao, Arturo, Espiritualismo y positivismo en el Uruguay, CEAL y Univ. de la República, 1968.

Ardao, A., Etapas de la inteligencia uruguaya, Montevideo, Universidad de la República, 1971.

Capítulo Oriental, "Acevedo Díaz y los orígenes de la narrativa", No.6, Montevideo, CEAL, 1968.

Deus, Sergio, Eduardo Acevedo Díaz. El caudillo olvidado, Montevideo, Editorial Acali, 1978.

Espinola, Francisco, Prólogo a la edición de Ismael, Ed. Jackson Inc., Bs. As., 1946.

Espinola, F., Prólogo a Soledad y El combate de la tapera, Biblioteca Artigas, Montevideo, 1954.

Ibañez, R. Prólogo a Ismael, Biblioteca Artigas, Montevideo, 1953.

Otero, E., Prólogo a Soledad y El combate de la tapera, Bs. As., EUDEBA, 1965.

Paternain, Alejandro, Acevedo Díaz, Arca, Montevideo, 1980.

Rodríguez Monegal, Emir, Eduardo Acevedo Díaz, Montevideo, 1963.

Zum Felde, Alberto, "Eduardo Acevedo Díaz", en: Proceso intelectual del Uruguay, Montevideo, 1967.

\section{Historia y cultura uruguaya}

Acosta y Lara, E., La guerra de los charrúas en la Banda Oriental, Tomo I y II, Montevideo, Librería Linardi y Risso, 1989.

Achugar, H., La balsa de la medusa, Montevideo, Trilce, 1992.

Achugar H., La biblioteca en ruinas, Montevideo, Trilce, 1994. 
Andacht, Fernando, Signos reales del Uruguay imaginario, Montevideo, Trilce, 1992.

Caetano, Gerardo, Historia contemporánea del Uruguay. De la Colonia al Mercosur, Montevido, Ed. Fin de Siglo, 1994.

Caetano, G. y Rilla, José, Breve historia de la dictadura, Montevideo, CLAEH, 1991.

Cosse, I. y Markarian, V., 1975: Año de la Orientalidad. Identidad, memoria e historia en una dictadura, Montevideo, Ed. Trilce, 1996.

Lerin, F. y Torres, C., Historia política de la dictadura uruguaya, 1973-1980, Montevideo, Ed. Nuevo Mundo, 1987.

Machado, Carlos, Historia de los Orientales, Tomos 1,2 y 3, Montevideo, Ed. Banda Oriental, 1992.

Nahum, Benjamín, La época batllista, Montevideo, Ed. Banda Oriental, 1993.

Pintos, Francisco, De la dominación española a al Guerra Grande, Montevido, 1942.

Real de Azúa, Los origenes de la nacionalidad uruguaya, Ed. Arca.

Reyes Abadie, W., Bruschera, O. y Melogno, T., El ciclo artiguista, Tomos 1, 2 y3, Montevideo, 1968.

Viñar, Maren y Marcelo, Fracturas de memoria, Montevideo, Trilce, 1993.

VVAA. dirección general Angel Rama, Enciclopedia Uruguaya, Montevideo,1968-70.

AAVV, Cultura(s) y nación en el Uruguay de fin de siglo, Montevideo, Trilce, 1991

AAVV, Identidad uruguaya: ¿mito, crisis o afirmación?, Montevideo, Trilce, 1992.

AAVV, Mundo, región, aldea. Identidades, políticas culturales e integración regional, Montevideo, Trilce, 1994.

\section{Dictadura. historia y critica literaria}

Brunner, Autoritarismo en Argentina, Brasil, Chile y Uruguay, Flacso, 1981.

Avellaneda, Andrés, Censura, autoritarismo y cultura. Argentina 1960-1983, Bs.As., CEAL,

Ciancaglini, S., Granovsky, M., Crónicas del Apocalípsis, Bs. As. Editorial Contrapunto, 1986. 
Echegaray, Fabián y Raimondo, Ezequiel, Desencanto político, transición y democracia, Bs.As., CEAL, No. 177.

García, Alicia, La Doctrina de la Seguridad Nacional, Bs. As. CEAL, Colección Biblioteca Política Argentina, 2 tomos, No. 333 y 334.

Germani,Gino, El concepto de la marginalidad, raices historicas y cuestiones teoricas, Nueva Vision, Bs As, 1973.

Castañeda, Jorge, La utopía desarmada. El futuro de la izquierda en América Latina. Bs. As. Ed. Espasa Calpe, 1993.

Castiglioni, Marta, La militarización del Estado en la Argentina (1976/1981), Bs. As., CEAL, Col. Biblio. Pol. Arg., No. 350.

Oszlak y otros, Proceso, crisis y transicion democratica, CEAL, 1984.

Reati, Fernando, Nombrar lo innombrable, Legasa, 1992.

Sosnowsky y otros, Represion y reconstruccion de una cultura. El caso argentino, Bs. As., Eudeba, 1988.

Sosnowsky y otros, Represión, exilio y democracia: la cultura uruguaya, Montevideo, 1990.

Veiga, Raúl, Las organizaciones de derechos humanos, Bs.As., CEAL, No. 127.

VVAA, comp. Bruno, Cavarozzi, Palermo, Los derechos humanos en la democracia, Bs.As., CEAL, No. 92.

VVAA, Ficción y política. La narrativa argentina durante el Proceso militar, Bs. As., Alianza, 1987.

VVAA, La impunidad. Una perspectiva psicosocial y clínica. Ed.

Sudamericana. 1995.

\section{Debates de fin e siglo}

Brunner, José J., "Notas sobre la posmodernidad y lo moderno en la cultura latinoamericana", en: David y Goliath, Bs.As., Año XVII, No. 52, 1987.

Cartografias de la modernidad, Santiago de Chile, 1994.

"Entonces ¿ existe o no la modernidad en América Latina?", en: Punto de Vista, Bs. As., Año X, No. 31, 1987.

Calderón, Fernando, "América Latina: Identidad y tiempos mixtos", en: David y Goliath, Bs.As., Año XVII, No. 52, 1987.

García Canclini, Néstor, Culturas Hibridas. Estrategias para entrar y salir de la modernidad, Bs. As., Editorial Sudamericana, 1992. 
"Los estudios culturales de los 80 a los 90: perspectivas antropológicas y sociológicas en América Latina", En Punto de Vista, Bs. As., Añ XIV, No. 40, jul/set., 1991.

Hinkelammert, Franz, "Frente a la cultura de la posmodernidad: proyecto político y utopía", en David y Goliath, Bs. As., Año XVII, No.52, 1987.

Lechner, Norbert, "Un desencanto llamado posmodernidad", en: Punto de Vista, Bs. As., Año XI, No. 33, 1988.

Richard, Nelly, "Periferias culturales y descentramientos posmodernos (marginalidad latinoamericana y recompaginación de los márgenes", En Punto de Vista, Bs. As., Añ XIV, No. 40, jul/set., 1991.

Schmucler, Hector, "Los rostros familiares del totalitarismo. Nación, Nacionalismo y pluralidad", en: Punto de Vista, Bs. As., Año XI, No.33, set/dic. 1988.

VVAA, Fragmentación cultural y nuevas identidades, en: revista Sociedad, UBA, Bs. As., No.4, 1994.

VVAA, La democracia latinoamericana: entre la ineficiencia y la pobreza, en: revista Sociedad, UBA, Bs. As., No.2, 1994.

VVAA, Problemas de América Latina, No.6/7, Montevideo, 1992.

VVAA, El surgimiento de la antropología posmoderna, Barcelona, Gedisa, 1992.

7 Artículos, entrevistas, polémicas aparecidas en semanarios, suplementos culturales y revistas de uruguay

Achugar, Hugo, "Las ciencias sociales: historia, sociología, economía ¿literatura?, Cuadernos de Marcha, Tercer Epoca, Año IV, No.39, 1989.

"Como el Uruguay no hay, ¡Bernabé, Bernabé! y el referendum", Cuadernos de Marcha, Tercer Epoca, Año IV, No.40, 1989.

"El referendum no leído y otros problemas de hemeneútica bifocal", Cuadernos de Marcha, Tercer Epoca, Año IV, No.42, 1989.

Berbejillo, Hugo, "Una literatura de descubrimiento", en Graffiti, No.27, Año 3, marzo 1993.

Butazzoni, Fernando: "Escribir la historia sin esquemas", entrevista realizada por Sergio Stipanic, en: El País Cultural, Año VI, No.309, 6 de octubre de 1995. 
Caétano, Mericy, "La nueva narrativa histórica de los escritores uruguayos", Cuadernos de Marcha, Tercer Epoca, Año XI, No.95, 1994.

"La desaparición, recurrencia en la nueva narrativa histórica del Uruguay", en Graffiti, No. 49, Año 5, enero-febrero 1995.

De Mattos, Tomás, "Bernabé, Bernabé. Respuesta a Lockhart", Brecha, Año IV, No.165, 20 de enero de 1989.

"Lo que sintió Josefina", Cuadernos de Marcha, Tercer Epoca, Año VII, No.74, 1992.

"Narrativa uruguaya y cultura de impunidad" (I) Cuadernos de Marcha, Tercer Epoca, Año VII, No.74, 1992.

"Narrativa uruguaya y cultura de impunidad" (II) Cuadernos de Marcha, Tercer Epoca, Año IX, No.85, 1993.

Gadea, Raúl, "El inquietante auge de nuestra novela histórica", en Graffiti, No. 37-38, enero-febrero 1994.

Larre Borges, Ana Inés, "Los ojos de Andrómaca", Brecha, Año IV, No. 166, 27 de enero de 1989.

"Próxima navegación de Tomás de Mattos. La fragata de las máscaras.", Brecha, Año VII, No. 358, 9 de octubre de 1992.

Lockhart, Washington, "¡Bernabé, Bernabé! Leído con lentes bifocales", Cuadernos de Marcha, Tercer Epoca, Año IV, No.41, 1989.

"ßBernabé... y su antiética". Cuadernos de Marcha, Tercer Epoca, Año IV, No.43, 1989.

"Bernabé, Bernabé...y Fructuoso", Brecha, Año IV, No. 164, 13 de enero de 1989.

"La historia desvencijada en ¡Bernabé...!", Brecha, Año IV, No. 167, 3 de febrero de 1989.

"Bernabé es novela y es historia", Brecha, Año IV, No. 173, 17 de marzo de 1989.

Paladino, Clara, "Tomás de Mattos, ¡Bernabé, Bernabé!", en: Revista Iberoamericana, No. 160-161, Vol. LVIII, julio-diciembre 1992, (p. 1227-1231)

Peyrou, Rosario, "Los espejos de la historia",El País Cultural, 17 de febrero de 1989.

"Vencedores y vencidos"El País Cultural, 24 de febrero de 1989.

"Con Tomás de Mattos. 'No quiero ser juez de la historia' ", El País Cultural, Año II, No.144, 7 de agosto de 1992.

Ponce de León, Napoleón B., "Lo que Josefina Péguy no dijo", Cuadernos de Marcha, Tercer Epoca, Año VII, No.73, 1992. 
Rocca, Pablo, "La "novela" de la historia uruguaya", Brecha, Año X, No. 496, 2 de junio de 1995.

Entrevistas a Tomás de Mattos: en Brecha, Año IV, No. 158, 25 de noviembre de 1988 y No.106, Año III, 13 de noviembre de 1987. 